\title{
INSTRUCTIVE COMPOSITES FOR BONE REGENERATION
}

Davide Barbieri

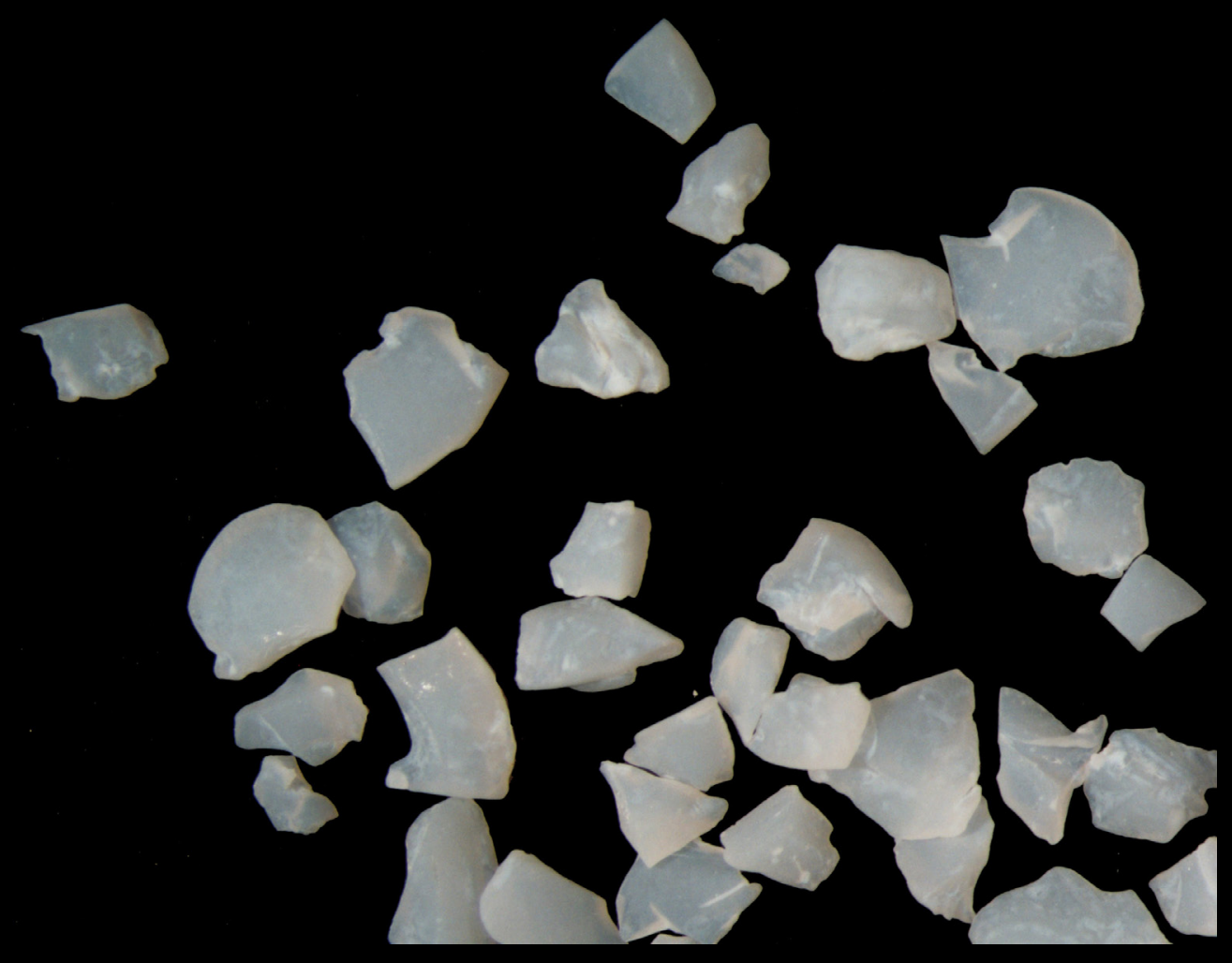




\section{INSTRUCTIVE COMPOSITES \\ FOR BONE REGENERATION}

Davide Barbieri 


\section{Members of the Committee}

\section{Chairman}

Prof. Dr. G. van der Steenhoven - University of Twente

\section{Promoter}

Prof. Dr. J.D. de Bruijn - University of Twente

\section{Assistant Promoter}

Dr. H. Yuan - University of Twente

\section{Members}

Prof. Dr. W.J.A. Dhert - University Medical Center Utrecht

Prof. Dr. S. Farè - Polytechnic of Milano

Prof. Dr. D.W. Grijpma - University of Twente

Prof. Dr. J.A. Jansen - Radboud University Medical Center Nijmegen

Dr. M.A.B. Kruft - Purac Biomaterials

Prof. Dr. C.A. van Blitterswijk - University of Twente

\section{Instructive composites for bone regeneration \\ Davide Barbieri}

$\mathrm{PhD}$ thesis, University of Twente, Enschede, the Netherlands

ISBN: $978-90-365-3441-3$

The research described in this thesis was entirely supported by

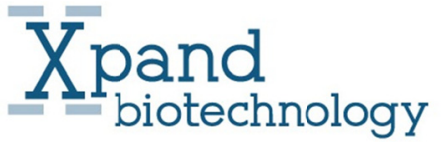

Other main financial supporting sources for this research project were

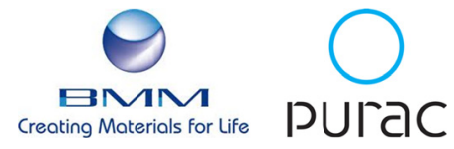

The printing of this publication was sponsored by

\section{DSM}

The research was mainly performed at Xpand Biotechnology $B V$, and parts were done in the Biomaterials Science and Technology (BST) and Tissue Regeneration (TR) departments at the University of Twente, and in the Biomaterials Laboratory at the Polytechnic of Milano (Italy). 


\title{
INSTRUCTIVE COMPOSITES \\ FOR BONE REGENERATION
}

\section{DISSERTATION}

\author{
to obtain \\ the degree of doctor at the University of Twente \\ on the authority of the rector magnificus, \\ Prof. Dr. H. Brinksma, \\ on account of the decision of the graduation committee, \\ to be publicly defended
}

on Thursday December $13^{\text {th }}, 2012$ at 16.45 hrs.

by

Davide Barbieri

born on May 25th 1981

in Vimercate, Italy 
This dissertation has been approved by

\section{Promoter}

Prof. Dr. J.D. de Bruijn - University of Twente

\section{Assistant Promoter}

Dr. H. Yuan - University of Twente

(c) 2012, D. Barbieri. Neither this book nor its parts may be reproduced without permission of the author.

ISBN: 978-90-365-3441-3 
献给潘瑧

A mamma e papà

A Stefano 



\section{Table of contents}

Summary

p. i

Samenvatting

p. $\mathrm{V}$

Riassunto

p. ix

Chapter 1 - Introduction

p. 1

Chapter 2 - The role of gels in bone instructive putties

p. 25

Chapter 3 - Instructive composites: effect of filler content on osteoinduction

p. 47

Chapter 4 - Controlling dynamic mechanical and degradation properties in instructive composites

p. 69

Chapter 5 - Effects of alkali surface treatment on the properties of nano-apatite and polymer composites

p. 89

Chapter 6 - Fluid uptake as instructive factor in biomaterials for bone tissue regeneration

Chapter 7 - Implications of polymer molecular weight in instructive composites for bone tissue regeneration

Chapter 8 - General discussion

p. 181

References

p. 191

Acknowledgements

p. 223

Resume

p. 227

List of publications

p. 228 



\section{Summary}

Developing new biomaterials for tissue regeneration requires careful balance between many factors, which is challenging because, on one side, such materials must provide complex information, through their physicochemical properties to actively interact with the biological surroundings and induce tissue regeneration. On the other side, regulatory issues, costs and ease of use of the final device, require low system complexity. For this reason, an emerging strategy is not attempting to recreate the complexity of tissues in vitro, but to focus on synthetic materials that have 'intrinsic' features that can instruct cells in vivo finally determining their fate. Therefore, newly developed biomaterials should be carefully designed to have specific local characteristics (e.g. surface stiffness, chemistry and topography) that can induce controlled cellular behaviors ultimately leading to tissue regeneration. In bone tissue regeneration by biomaterials, such instructing phenomenon is referred as 'osteoinduction'.

In this thesis we aimed to develop simple biomaterial systems, i.e. composites of two phases (i.e. polymer and calcium phosphate) that could be able to interact with the biological system. In particular, we have striven to understand the role of some 'intrinsic' characteristics of the composite phases (e.g. calcium phosphate content, polymer molecular weight and monomer chemistry) in determining crucial phenomena occurring at the interface between biomaterial and biological environment. Such surface processes, e.g. surface mineralization and protein adsorption, play key roles in instructing (stem) cells leading to bone tissue regeneration. Besides this, we also studied how the mechanical and physical properties of the composites were affected by the two phases and tried to develop a material with as close properties as possible to those of bone tissue.

Adding a polymer (hydro)gel to osteoinductive ceramic granules leads to putties and/or injectable pastes with improved handling properties. However, covering the micro-structured ceramic surface with a slowly dissolvable polymer (hydro)gel could inhibit or delay cell adhesion and thus osteoinduction. To verify this hypothesis, we studied the effect of various polymer binders on the bone induction of their putties comprising micro-structured ceramics in Chapter 2. Our results indicated that (hydro)gels with a slow dissolution rate not only hinder the contact between the ceramic micro-structured surfaces and cells from the surroundings, but may also obstruct vasculature formation and soft tissue infiltration. It was therefore concluded that the binder chemistry and dissolution rate are crucial parameters to allow material-directed osteoinduction of putties and injectable pastes.

The brittleness of ceramics restricts their use as fillers in mechanically non-loaded sites, thus there is need of biologically active composites that allow load bearing. 
At the same time, to favor full replacement of implants with new bone tissue, their degradation is crucial. In a pilot study (Chapter 3 ), we successfully prepared an osteoinductive porous composite with poly(D,L-lactide) and nano-apatite particles. The inorganic component caused surface micro-structure, which was proposed as main osteoinduction trigger. To improve the mechanical properties, we prepared dense composites with homogeneous apatite distribution (Chapter 4) and observed that, despite thermal/mechanical polymer phase degradation, extrusion could be used to prepare homogeneous composites with mechanical properties comparable to dry bone (Chapter 4). Extrusion decreased the polymer phase molecular weight depending on the starting molecular weight and the filler content (Chapters 4, 5) and greatly influenced the viscoelastic properties of the resulting composites. On the contrary, solvent-based methods (Chapter 3 ) did not degrade the polymer but led to inhomogeneous materials. The method used to manufacture composites is therefore an important factor as regards to their mechanical and degradation performances.

We also observed that the apatite content in composites was directly related to their osteoinductive potential (Chapter 3), where contents higher than 40\%wt. induced heterotopic bone formation. Furthermore, we observed that increasing nano-sized filler contents stiffened the composites, whereas they degraded the polymer phase during extrusion increasing their final damping abilities (Chapter 4). Higher fluid uptake was observed in high apatite containing composites, which led to large decreases in stiffness and increased their viscoelasticity (Chapter 4). Higher fluid uptake also led to quicker apatite dissolution and polymer hydrolysis causing larger mass loss and ion release (important bone signaling molecules). Besides stiffening and rendering the composites more degradable, high filler content also enhanced surface mineralization (Chapters 3,7 ). Furthermore, apatite rendered the composite surfaces rougher and we observed that such surfaces induced significantly more osteogenic differentiation of human bone marrow stromal stem cells (Chapter 7). These events may have contributed to the triggering of heterotopic bone formation in composites with a filler content higher than $40 \%$ wt. (Chapter 3 ). It can therefore be concluded that the filler content is a critical factor as it controls, either directly or indirectly, many features including hydrophilicity, elasticity and viscoelasticity, degradation and surface roughness that will affect the performance of composites in vitro and in vivo.

We observed that the roughest composite material adsorbed more proteins, surface mineralized and was able to trigger osteogenic differentiation of human bone marrow stromal stem cells (Chapter 5 ). In view of these properties, we expected that it would initiate bone formation. But osteoinduction was not observed, most probably because of the semi-crystalline polymer used (i.e. copolymer 
containing $96 \%$ mol. L-lactide), which led to excessively slow degradation. In vitro results indicated that surface roughness is a parameter affecting the final material properties with implications on its biological performances, but we should consider the limitation of in vitro systems and thus be careful in the extrapolation to the complex in vivo environment.

We studied the role of two intrinsic properties of the polymer phase, i.e. the molecular weight and the choice of monomer, on osteoinduction. We observed that polymers with low molecular weight or containing D,L-lactide monomer led to larger fluid uptake in their composites (Chapters 6,7), indirectly enhancing their biological properties. In particular, composites containing such polymers activated a cascade of surface events where nano-structured mineralized surfaces formed on which serum proteins were adsorbed. Cell colonization and differentiation on such mineralized surface may have been guided by the adsorbed protein motifs, leading later to heterotopic bone formation. Larger fluid uptake also caused more degradation, which released ions and increased the available space for bone ingrowth. Further, increased stiffness and decreased damping were seen for those composites with high molecular weight or low D, L-lactide containing polymers.

To examine whether a common general link between material properties and osteoinduction exists (Chapter 6), we observed that hydrophilicity, in general, improved the contact between fluids and biomaterials leading to larger fluid uptake. Since fluids carry various molecules and ions, such improved contact enhanced biomolecule adsorption and surface mineralization. Thus, the early cell response upon implantation may have been improved; triggering cytokine production by macrophages and eventually inducing bone formation. Further, absorbed fluids enhanced biomaterial degradation and facilitated the release of calcium and phosphate ions together with changes at the surface structure, for example by generating nano- or micro-porosity. The combination of such phenomena triggered by fluid uptake contributed to heterotopic bone formation. Although it was possible to apply this general hypothesis only to each class of biomaterial separately, it was not valid under a more general 'biomaterial' view (Chapter 6).

In this thesis we evaluated some crucial factors in the design of instructive composite biomaterials. However, other factors that were not evaluated in this work, such as the monomer content after extrusion, or changes in polymer crystallinity, should not be excluded from having an effect on the biological properties of instructive composites. 



\section{Samenvatting}

Bij de ontwikkeling van biomaterialen voor weefselregeneratie, is het vinden van een balans tussen verschillende factoren van cruciaal belang. Aan de ene kant moeten de materialen, door hun fysisch/chemische eigenschappen, complexe informatie kunnen doorgeven om zo een active interactie aan te gaan met hun biologische omgeving. Aan de andere kant wordt een simpliciteit van het materiaal gevraagd om zo het gebruikersgemak te verhogen, regulatoire obstakels te vermijden en kosten voor de ontwikkeling en het klinische gebruik zo laag mogelijk te houden. Daarom wordt in toenemende mate bij de ontwikkeling van biomaterialen niet geprobeerd het weefsel te imiteren, maar ligt de focus op de ontwikkeling van synthetische materialen met intrinsieke eigenschappen (i.e. compositie, oppervlakte topografie, etc.), die de omliggende cellen instructies kunnen geven en aansturen tot weefselregeneratie. Bij biomateriaal gereguleerde botregeneratie wordt deze instructie 'osteoinductie' genoemd. Het onderzoek beschreven in dit proefschrift is er op gericht om een synthetisch, instructief composiet materiaal (polymeer met calciumfosfaat) te ontwikkelen dat de mechanische en regeneratieve eigenschappen van botweefsel imiteert. Er is specifiek gekeken naar het effect van intrinsieke materiaaleigenschappen (compositie, moleculair gewicht van de gebruikte polymeren, monomeer chemie oppervlakte topografie en ruwheid) op de instructieve eigenschappen van het composiet. Met name oppervlakte gerelateerde processes zoals mineralisatie en eiwitadsorptie zijn onderzocht omdat die een cruciale rol kunnen spelen in het instrueren van (stam)cellen tot botweefselregeneratie. Daarnaast is gekeken naar de invloed van intrinsieke materiaal eigenschappen op de mechanische en fysische eigenschappen van het ontwikkelde composiet in vergelijking met dat van botweefsel.

Wanneer een polymere (hydro)gel wordt gecombineerd met osteoinductieve keramische granulen ontstaat een pasta die gemakkelijk bewerkt kan worden. Echter als het microporeuse keramische oppervlak van deze granules bedekt wordt met een langzaam degradeerbaar polymere (hydro)gel, kan het polymeer de adhesie van cellen aan het oppervlak beinvloeden en daarmee het osteoinductieve potentieel van de keramische granules limiteren. In hoofdstuk 2 van dit proefschrift is het effect bekeken van verschillende polymeren, in combinatie met osteoinductieve poreuze keramische granulen, op de osteoinductiviteit van de gemaakte pasta's. De resultaten laten zien dat langzaam degraderende (hydro)gels niet alleen het contact blokkeren tussen de microstructuur van de osteoinductieve granules en de omliggende cellen, maar ook vascularisatie en ingroei van zacht weefsel in de poreuze structuur van de granulen verhinderen. De resultaten laten daarmee zien dat de degradatiesnelheid en chemie van het polymeer cruciale parameters zijn bij de ontwikkeling van een osteoinductieve pasta. 
De behoefte aan een degradeerbaar composiet materiaal van osteoinductieve keramische poreuse granulen en een polymeer voor gewichtdragende bot locaties komt voort uit de mechanische kwetsbaarheid van keramische implantaten. Daarnaast is degradatie van de keramische implantaat vereist om een volledige genezing van het defect mogelijk te maken. In hoofdstuk 3 van dit proefschrift is beschreven hoe een osteoinductief poreus composiet met poly( $\mathrm{D}, \mathrm{L}$-lactide) en nano-apatiet deeltjes gemaakt kan worden. De anorganische component van dit composiet zorgt voor een oppervlakte microstructuur waarvan wordt aangenomen dat deze verantwoordelijk is voor het osteoinductieve potentieel van het materiaal. Om de mechanische eigenschappen te verbeteren zijn composieten gemaakt met een homogeen apatiet distributie (hoofdstuk 4). Ondanks thermische en mechanische degradatie van het polymeer, kan extrusie gebruikt worden bij het maken van homogene composieten met mechanische eigenschappen vergelijkbaar aan die van (droog) bot (hoofdstuk 4). Extrusie verlaagt het moleculair gewicht van de polymere fase van de composiet. Het uiteindelijke moleculair gewicht is afhankelijk van de start moleculair gewicht van het polymeer (hoofdstuk 4, 5). Deze laatste eigenschap heeft grote invloed op de viscoelastische eigenschappen van de gemaakte composieten. Dit in tegenstelling tot composieten die zijn gemaakt via een oplosmiddel methode (hoofdstuk 3), die geen degradatie van het polymeer laten zien maar wel een inhomogeen composiet opleveren. Daarmee is aangetoond dat de methode die gebruikt wordt voor het maken van composieten een belangrijke invloed heeft op de mechanische en degradatie eigenschappen van het composiet.

Het apatiet gehalte in een composiet is bepalend voor het osteoinductieve potentieel (hoofdstuk 3). Composieten met een apatiet gehalte van meer dan $40 \%$ (in gewicht) laten heterotope botvorming zien. Daarbij wordt, door het toenemende apatiet gehalte, het composiet ook stijver en de wateropname verhoogd (hoofdstuk 4). Echter laat een toenemende wateropname in het composiet ook een afname in stiffheid en een toename van de visco-elasticiteit zien (hoofdstuk 4). Een toenemende wateropname leidt ook tot een hogere oplosbaarheid van het apatiet en hydrolyse van het polymeer, wat weer een snellere afname van massa en afgifte van ionen (belangrijke signaal moleculen) tot gevolg heeft.

Naast een hogere stijfheid en wateropname laten composieten met een hoog apatiet gehalte ook meer oppervlakte mineralizatie zien (hoofdstuk 3 en 7). Daarnaast geeft apatiet het composiet een hogere oppervlakte ruwheid die verantwoordelijk is voor een inductie van osteogene differentiatie van beenmergcellen (hoofdstuk 5). Al deze factoren kunnen aanleiding geven tot heterotope botvorming door composieten met een apatiet gehalte van meer dan $40 \%$ (hoofdstuk 3 ). Het apatiet gehalte in het composiet is daarmee een kritische factor bij het maken van een osteoinductief materiaal omdat deze direct of indirect diverse eigenschappen (wateropname, elastisiteit, visco- 
elasticiteit, degradatiesnelheid, oppervlakte ruwheid) bepaalt die de in-vivo en in-vitro karakteristieken van het composiet bepalen.

Uit composieten met verschillende oppervlakte ruwheden bleek dat het materiaal met de grootste oppervlakte ruwheid het meeste eiwitten absorbeert en ook meer osteogene differentiatie van beenmergcellen laat zien (hoofdstuk 5). Daarom was verwacht dat het composiet met de grootste oppervlakte ruwheid tot heterotrope botvorming zou leiden, hetgeen niet het geval was. Waarschijnlijk komt dit omdat een semi-kristallijn polymeer (i.e. copolymeer met $96 \%$ L-lactide) gebruikt is, dat leidt tot een uiterst langzame degradatie van het composiet. In-vitro resultaten hebben laten zien dat oppervlakte ruwheid effect heeft op de uiteindelijke materiaal eigenschappen en de daaruit voortvloeiende biologische eigenschappen. We moeten echter de limitaties van in vitro systemen onder ogen blijven zien en daarom voorzichtig zijn in de extrapolatie naar de complexe in vivo omgeving.

De rol van twee intrinsieke eigenschappen van het polymeer deel van het composiet (moleculair gewicht en monomeer gehalte) op het osteoinductieve potentieel van de composiet is onderzocht in hoofdstuk 6 en 7 . Polymeren met een laag moleculair gewicht die D,L-lactide als monomeer bevatten, leiden tot een hogere vloeistofopname in het composiet, waarmee de biologische eigenschappen van zo'n composiet ook worden beïnvloed. Composieten met deze polymeren activeren een stroom aan oppervlakte gebeurtenissen, waar onder andere nano gestructureerde gemineraliseerde oppervlakten worden gevormd waarop serum eiwitten kunnen adsorberen. Kolonisatie en differentiatie van cellen op zulke gemineraliseerde oppervlakten worden beïnvloed door de geabsorbeerde eiwitten wat later kan leiden tot heterotope botvorming. Een hogere vloeistofopname veroorzaakt ook meer degradatie van het composiet wat weer tot gevolg heeft dat er meer ruimte beschikbaar komt voor bot ingroei. Composieten met een hoog moleculair gewicht of met een lage D,L-lactide hoeveelheid, laten een verhoogde stijfheid en een verlaagde wateropname zien.

Twee verschillende typen biomaterialen (i.e. calciumfosfaat keramieken en composieten) zijn geëvalueerd om te zien of er een gemeenschappelijke materiaal eigenschap bestaat die verantwoordelijk is voor de osteoinductieve potentie van een materiaal (hoofdstuk 7). In het algemeen bevorderen hydrofiele materialen het contact tussen vloeistoffen en biomaterialen, wat een verhoogde vloeistofopname tot gevolg heeft. Omdat biologische vloeistoffen verschillende moleculen en ionen bevatten zal een hydrofiel materiaal ook een verhoogde eiwit en ionen opname laten zien, en daarmee een verhoogde oppervlakte mineralisatie. De vroege cel reactie na implantatie van een biomateriaal kan hiermee versnelt worden, waarmee ook de cytokine productie door macrofagen wordt versnelt, en wellicht botformatie. Daarbij verhogen geabsorbeerde vloeistoffen de degradatie van het biomateriaal waarbij het vrijkomen van calcium en fosfaat ionen, in combinatie met de veranderingen aan de oppervlakte 
structuur, bespoedigt worden. De balans van deze fenomenen, geïnitieerd door vloeistofopname dragen bij aan heterotope botvorming. Alhoewel deze hypothese valide was op de hierin onderzochte composieten, is hij niet toepasbaar op biomaterialen in het algemeen (hoofdstuk 6).

Het werk dat beschreven staat in dit proefschrift heeft een aantal essentiële factoren geëvalueerd die in ogenschouw moeten worden genomen bij de ontwikkeling van instructieve composieten. Er bestaan echter ook andere factoren waaronder de hoeveelheid monomeer in het composiet of de verandering van de kristalliniteit van het polymeer, die bij dit onderzoek niet zijn meegenomen maar ook bepalend kunnen zijn voor de biologische eigenschappen van instructieve composieten. 


\section{Riassunto}

Sviluppare nuovi biomateriali per la rigenerazione dei tessuti richiede un difficile bilancio tra molti fattori. Da un lato questi materiali devono, attraverso le loro proprietà fisico-chimiche, fornire informazioni complesse al sistema biologico con cui interagiscono per indurre la rigenerazione del tessuto. Dall'altro lato, problemi normativi, costi e il bisogno di semplicità d'uso del materiale richiedono un basso livello di complessità progettuale. Per questi motivi, varie strategie emergenti puntano a sviluppare materiali sintetici aventi 'proprietà intrinseche' che possano direttamente determinare il destino delle cellule, invece che di ricreare la complessità dei tessuti biologici in laboratorio. Di conseguenza, i nuovi biomateriali devono essere progettati con particolari caratteristiche locali (p.es. livello di rigidità, composizione chimica e topografia della superficie) che istruiscano le cellule e inducano la rigenerazione del tessuto. Nel campo della rigenerazione del tessuto osseo con biomateriali, questo fenomeno istruttivo è chiamato 'osseoinduzione'.

In questa tesi avevamo come obiettivo quello di sviluppare semplici materiali 'istruttivi', cioè compositi di polimeri e calcio fosfati, capaci di interagire con il sistema biologico. In particolare, ci siamo sforzati di capire come le proprietà intrinseche delle fasi costituenti i compositi (p.es. il contenuto di calcio fosfato, il peso molecolare del polimero e il tipo di monomero) influenzino sui fenomeni che succedono all'interfaccia tra il biomateriale e l'ambiente biologico circostante. Questi fenomeni di superficie, p.es. la mineralizzazione e l'adsorbimento proteico, hanno ruoli chiave nell'istruzione delle cellule guidandole verso la rigenerazione del tessuto osseo. Oltre a questo, abbiamo anche valutato come le proprietà fisiche e meccaniche dei compositi fossero influenzate dalle fasi costituenti e abbiamo cercato di sviluppare un materiale che avesse caratteristiche il più simili possibile a quelle del tessuto osseo.

Mischiare un (idro)gelo polimerico con granuli di ceramica osseoinduttiva permette di avere delle paste malleabili o iniettabili, che facilitano la chirurgia. Comunque, ricoprire la superficie microstrutturata della ceramica con (idro)geli a dissoluzione lenta potrebbe rendere difficoltosa l'adesione cellulare e quindi ritardare, 0 addiritura annullare, l'osseoinduzione. II Capitolo 2 descrive uno studio fatto sugli effetti che diversi gel polimerici hanno sul potenziale osseoinduttivo di paste malleabili ed iniettabili contenti ceramiche osseoinduttive. I risultati hanno indicato che (idro)geli lentamente dissolvibili non solo rendono difficile il contatto tra la superficie della ceramica e le cellule circostanti, ma ostacolano anche la formazione di nuovi vasi sanguigni e l'infliltrazione di tessuti nell'impianto. Di conseguenza, l'ossoinduzione è resa più difficoltosa. Quindi è stato concluso che la composizione chimica e la 
velocità di dissoluzione dell'idrogelo usato sono cruciali per l'osseoinduzione di paste malleabili o iniettabili.

La fragilità delle ceramiche limita il loro uso a quello di riempitivi in siti non sollecitati meccanicamente, e quindi c'è il bisogno di sviluppare compositi osseoinduttivi che possano anche tollerare carichi meccanici. Nello stesso tempo, per favorire la sostituzione completa dell'impianto con nuovo tessuto osseo, la degradazione dei compositi è importante. In uno studio pilota (Capitolo 3) abbiamo preparato un composito poroso osseoinduttivo con acido poli(D,L-lattico) e nanoparticelle di apatite. La componente inorganica ha generato una struttura superficiale microstrutturata, che è stata proposta come il principale attivatore dell'osseoinduzione di questi compositi. Nel tentativo di migliorarne le proprietà meccaniche, sono stati preparati compositi densi con una distribuzione omogenea di apatite (Capitolo 4). $\grave{E}$ stato osservato che, nonostante provochi la degradazione termica e meccanica della componente polimerica, l'estrusione può essere usata per la produzione di compositi omogenei con proprietà meccaniche simili a quelle dell'osso in condizioni asciutte (Capitolo 4). L'estrusione ha diminuito il peso molecolare della fase polimerica, e questa diminuzione è dipesa dal peso molecolare iniziale e dal contenuto di apatite (Capitoli 4, 5). Questo fatto ha influenzato pesantemente sulle proprietà viscoelastiche dei compositi. Dal canto suo, metodi di preparazione dei compositi basati sull'uso di solventi (Capitolo 3) non ha degradato la componente polimerica ma ha portato a materiali inomogenei. Di conseguenza, la scelta del metodo usato per produrre i compositi è critica perchè può determinarne le prestazioni meccaniche e la degradazione.

È stato anche visto che il contenuto di apatite nei compositi ha determinato il loro potenziale osseoinduttivo (Capitolo 3 ), dove il materiale con almeno il $40 \%$ in peso di apatite ha indotto alla formazione eterotopica di tessuto osseo. In più, abbiamo osservato che l'aumento del contenuto di apatite ha reso i compositi più rigidi. Però, dato che un alto contenuto di apatite ha portato a una maggiore degradazione della fase polimerica durante l'estrusione, il composito aveva anche maggiori capacità di smorzamento sotto carichi meccanici ciclici (Capitolo 4). Inoltre, compositi con un alto contenuto di apatite hanno assorbito più liquidi portando a una sostanziale diminuzione in rigidezza e un aumento in viscoelasticità (Capitolo 4). Questo assorbimento di liquidi ha causato anche una rapida dissoluzione di apatite e idrolisi del polimero con conseguente perdita in massa e rilascio di ioni, che sono importanti molecole segnale per l'osso. Oltre che a rendere i compositi più rigidi e degradabili, un alto contenuto di apatite ha anche favorito la mineralizzazione delle superfici (Capitoli 3,7 ). È stato osservato che l'apatite ha reso la superficie dei compositi più rugosa, e che tale superficie ha indotto una maggiore differenziazione 
nella linea osteogenica di cellule stromali derivate dal midollo osseo umano (Capitolo 5). Questi eventi potrebbero aver contributo ad iniziare la formazione eterotopica di osso nei compositi che avevano un contenuto di apatite di almeno il $40 \%$ in peso (Capitolo 3). In conclusione, il contenuto della componente inorganica è un fattore critico perchè può controllare, sia direttamente che indirettamente, molte proprietà quali l'idrofilicità, l'elasticità e la viscoelasticità, la degradazione e la rugosità di superficie che poi influenzano il comportamento dei compositi sia in vitro che in vivo. Dopo aver creato superfici con diversi livelli di rugosità, è stato osservato che il composito con la superficie più rugosa ha adsorbito una maggiore quantità di proteine, si è mineralizzato ed è stato in grado di indurre la differenziazione osteogenica di cellule stromali derivate dal midollo osseo umano (Capitolo 5). In vista di questi risultati, ci si aspettava che questo materiale avrebbe iniziato il processo di formazione ossea in vivo. Ma esso è risultato non osseoinduttivo, motlo probabilmente a causa del tipo di polimero usato (un copolimero semicristallino contenente il $96 \%$ mole di acido L-lattico) che potrebbe essere degradato troppo lentamente. Comunque, i risultati ottenuti in vitro hanno indicato che la rugosità di superficie è un parametro che può influenzare le proprietà e le prestazioni biologiche del composito. Ma bisogna anche considerare attentamente i limiti dei sistemi in vitro usati per studiare i biomateriali in laboratorio, soprattutto quando si cerca di estrapolare i risultati biologici ottenuti in vitro (p.es. colture cellulari 0 adsorbimento proteico) per descrivere la realtà in vivo.

Dopodichè, è stato analizzato il ruolo che il peso molecolare ed il monomero della fase polimerica hanno sull'osseoinduzione. Abbiamo visto che i compositi aventi polimeri con bassi pesi molecolari e/o contenenti il monomero acido D,L-lattico potevano assorbire più liquidi (Capitoli 6,7), migliorando in questo modo le loro proprietà biologiche. Questi compositi sono stati capaci di attivare una serie di eventi che hanno poi portato alla formazione di superfici mineralizzate e nanostrutturate, le quali hanno adsorbito proteine dai fluidi biologici. Colonizzazione e differenziazione cellulare su queste superfici potrebbero essere state influenzate dalle proteine adsorbite, con conseguente formazione di osso eterotopico. Grandi quantità di liquidi assorbiti hanno provocato anche una maggiore degradazione, che ha portato al rilascio di ioni ed incrementato lo spazio libero a disposizione per la formazione di nuovo tessuto osseo. Inoltre, un aumento della rigidezza e una diminuzione della viscoelasticità sono stati osservati nei compositi contenti polimeri ad alto peso molecolare o con un basso contenuto di acido D,L-lattico.

Due classi di biomateriali, cioè ceramiche calcio fosfate e compositi, sono state studiate per vedere se potesse esistere una regola generale che correli le proprietà dei materiali con il loro potenziale osseoinduttivo (Capitolo 7). L'idrofilicità, in 
generale, ha migliorato il contatto tra liquidi e biomateriali portando a un maggiore assorbimento di fluidi. Dato che i fluidi biologici contengono varie molecole ed ioni, un migliore contatto ha portato ad un aumento dell'adsorbimento di biomolecole e a superfici più mineralizzate. Quindi, la risposta cellulare che succede immediatamente dopo l'impianto potrebbe essere stata migliorata, p.es. portando al rilascio di citochine da parte di macrofagi, e potrebbe aver indotto alla formazione di osso. In più, l'assorbimento di liquidi ha anche aumentato la degradazione del biomateriale facilitando il rilascio di ioni calcio e fosftato e a cambiamenti sulla superficie, per esempio creando una nano- 0 microporosità. La combinazione di questi fenomeni attivata, dall'assrobimento di fluidi, potrebbe aver poi contribuito alla formazione eterotopica di osso. Comunque, è stato possibile applicare questa ipotesi generale solo alle singole classi di biomateriali, e questa regola non era valida per confrontare tra di loro diverse classi di materiali (Capitolo 6).

Il lavoro descritto in questa tesi ha valutato alcuni aspetti cruciali che devono essere considerati durante le fasi di ideazione e creazione di biomateriali compositi istruttivi. Comunque, altri fattori che non sono stati considerati in questa tesi, per esempio i possibili cambi del contenuto di monomero o della cristallinità del polimero dovuti all'estrusione, non possono essere esclusi dal gruppo di possibili fattori influenzanti l'osseoinduzione. 


\section{CHAPTER 1}

Introduction 



\subsection{Eukaryote multicellular organisms}

All living beings share some characteristics. In particular, all modern organisms are comprised of cells, which are present in two distinct types. Eukaryote cells have a nucleus enclosing the genetic material, while prokaryote cells lack of such nucleus. ${ }^{[1]}$ Similarly to prokaryotes, eukaryotes are surrounded by membrane and contain ribosomes, organelles responsible for the synthesis of proteins. However, the eukaryotic cellular structure is more complex and contains various other organelles, such as mitochondria, where various metabolic reactions occur. An important characteristic of cells is their capacity to generate copies of their own genetic material resulting in identical cells. Organisms based on prokaryote cells are always unicellular with very simple structure and include bacteria such as Escherichia coli, while eukaryotic living beings can be formed by one or more cells and their simplest representatives are yeasts. Multicellular organisms started to emerge when some unicellular eukaryotes, to survive the difficult environmental conditions on Earth, formed multicellular aggregates of only one cell type, such as the modern algae Volvox. ${ }^{[2]}$ The oldest fossil findings of primitive living life, i.e. the oldest cellular aggregates, date back to 3.5 billion years ago (Figure 1).[3,4] There is no evidence of life in earlier times, i.e. during the prebiotic era, but hypotheses have been formulated and experimentally verified in various experiments (Figure 1).[4-7] When cellular aggregates composed by different cellular types, having various functions, could mutually cooperate with each other (Figure 1), truly complex multicellular organisms arose. In such organisms cells are physically held together by a molecular and elastic framework and can communicate with each other in various ways, influencing on each other's fate..$^{[1]}$ Later, the continuous cellular specialization and division of labor amongst the cells in an organism led to the complexity and diversity of modern multicellular organisms, i.e. plants and animals. Each aggregate of specialized (i.e. differentiated) cells, or combinations of them, forms a solid mass of interconnected cells supported by structural macro-molecules. Such masses, performing diverse functions, are referred to as tissues. Groups of mutually cooperating tissues then compose various body parts that, together, will form what we call a 'living being'.

\subsection{The body tissues - matrices of molecules and differentiated cells}

Every tissue in multicellular organisms is formed by three-dimensional collagen structures, ${ }^{[8,9]}$ which provide supporting frameworks for cell adhesion, migration and polarity (Figure 2). The functions of such collagenous matrices have been demonstrated when heart tissue was decellularized and it provided a matrix that could support seeded cardiac and endothelial cells. ${ }^{[10]}$ Collagen in tissues varies per type according to the tissue functions. ${ }^{[8,9]}$ When collagen type $I$ is the most present, it 
forms a fibrous structure called interstitial matrix, whereas if mainly type IV it organizes into sheets generating basement membranes. ${ }^{[8]}$ The interstitial matrix fills the space between cells, blood and lymph vessels, while the basement membrane supports the epithelium lining the cavities and surface of organs such as the skin, or the endothelium in inner walls of blood vessels. Thanks to elastin micro-fibril networks localized in these collagenous matrices, all tissues have tensile strength with recoil abilities, particularly in blood vessels, skin, uterus and lung. ${ }^{[11]}$ Dispersed in these frameworks there are also macromolecules such as hyaluronan and proteoglycans. The latter act as modulators of inflammation and immune responses, and also participate in cell growth and differentiation. ${ }^{[12]}$ Hyaluronan can bind water forming a gel-like solution providing the tissues with resistance to compressive loads, damping and lubricating characteristics. ${ }^{[13]}$ To perform their specific function, every tissue hosts differentiated cells connected to the collagenous matrices through adhesive proteins, which are trans-membrane cell surface receptors. ${ }^{[14]}$ These molecules play crucial roles in living organisms by transmitting environmental signals to the cells that regulate their fate. Importantly, these complex tissue frameworks are continuously bathed by the interstitial fluid, which is an aqueous solution similar to blood plasma.
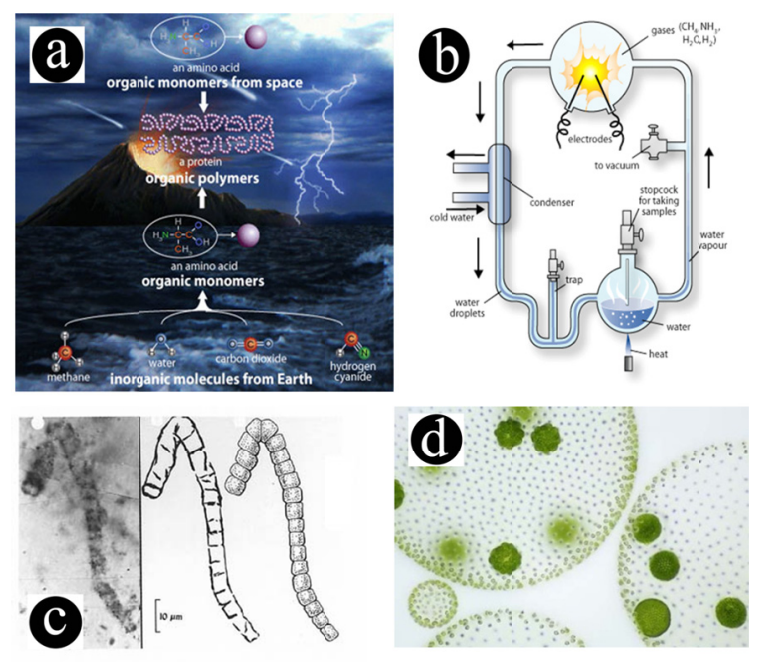

Figure 1. (a) It is hypothesized that the early Earth's reducing atmosphere provided conditions for the formation of organic polymers from either terrestrial or extraterrestrial monomers. ${ }^{[5,}$ 6] (b) Miller and Urey created the hypothesized primitive atmosphere with a mixture of methane, ammonia, hydrogen and water vapor in a bottle. As the mixture was circulated through the apparatus, sparks of electricity (to simulate lightning) were discharged. After eight days, the condensed water in the apparatus was analyzed and showed to contain amino acids along with a few other organic compounds, ${ }^{[6]}$ which are still nowadays the life bricks. (c) Natural and chemical evolution in the primitive world led to the formation of primordial cells that could aggregate and mutually cooperate. The figure represents a fossil of the earliest microorganisms found on Earth, which resembles filaments of modern blue-green algae (i.e. cyanobacteria). ${ }^{[4]}$ (d) Light micrograph of a colony of the modern freshwater green alga Volvox. ${ }^{[2]}$ The colony is a hollow sphere formed of thousands of cells connected by cytoplasmic threads. Each cell has two flagella used for locomotion. The dark green spheres within the colony are daughter colonies, which are produced asexually. All images were freely downloadable from the web (search with www.google.com, using the images filter). 
Interstitial fluid is the main transport medium for nutrients, bio-molecules and waste products between cells and the circulatory system. ${ }^{[15]}$ When the presence of solid components in the tissue framework is minor and liquids are the largest part, ${ }_{116]} a$ living being would be just a misshapen gelatinous mass of cells interconnected by a few neurons similar to jelly fishes such as the blob-fish and medusa (Figure 2). These examples highlight the crucial role of tissue frameworks in guaranteeing the body structural firmness. The complex supporting structures described till now are present in all tissues, and have unique characteristics to host different cellular phenotypes that make them specialized. For example, bone tissue has a highly mineralized interstitial matrix providing it with stiffness and capable to entrap osteoblasts and osteoclasts (for more details on bone tissue, see the key concept box 1). On the other side, cartilage tissue hosts chondrocytes embedded in a hydrated interstitial matrix. The balance of cellular proliferation, differentiation and apoptosis is pivotal in guaranteeing healthy conditions of tissues through the phenomena of tissue renewal, repair and regeneration.
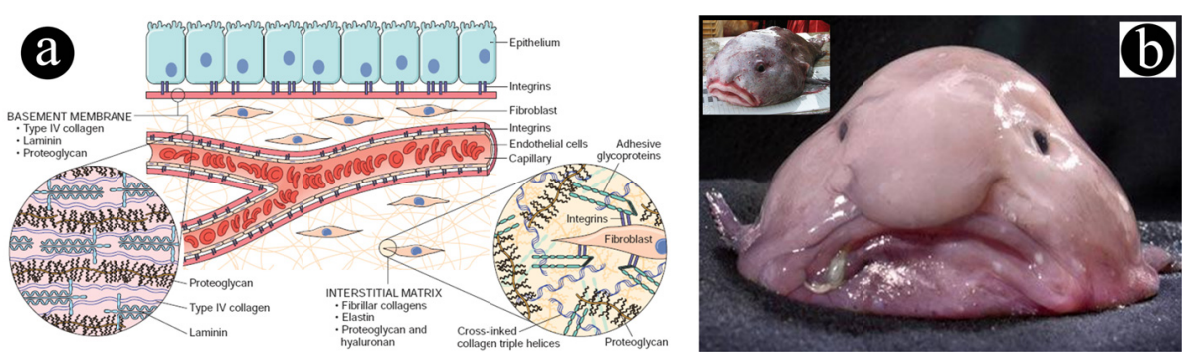

Figure 2. (a) Sketch representing the general structure of interstitial matrix and basement membranes with their main molecular elements including collagen, proteoglycans, and adhesive glycoproteins. Epithelial and mesenchymal cells (e.g. fibroblasts) interact with the matrix via integrins (i.e. a type of adhesion receptors). ${ }^{[14]}$ (b) The blob-fish (i.e. Psychrolutes marcidus), like other jelly fishes, typically floats above the sea floor (i.e. 600-1200 meters deep), where the high pressure makes the fishes' gas bladders inefficient for buoyancy. For this reason, their evolution led them having gelatin-based flesh with $95 \%$ or more of water and the remainder with $3.5 \%$ various types of salts and only $1.5 \%$ organic material. ${ }^{[16,17]}$ The organic content includes a matrix (i.e. mesoglea) of mucopolysaccharide and fibers of collagen. Although its little amount, the mesoglea provides a scaffold for the tissues and the few muscles of the fish. ${ }^{[16]}$ Buoyancy is controlled by the exclusion of certain ions, primarily sulfate, or accumulation of others such as ammonium in their goo mass. ${ }^{[17-19]}$ Unlike a fish, which retains its form when out of water, a jelly requires the support provided by the aqueous environment. In fact when taken out of water, their body consistence quickly collapses (this may be observed while walking on the sea coast, where occasionally small jelly fishes lay on beaches). These fishes essentially lack of true organ apparatus and have a few cells. For example they do not have a nervous system but just a loose network of nerves for the control of buoyancy or detection of light. They do not have a digestive apparatus or respiratory system as nutrients are absorbed by the few tissue cells and oxygen is captured by diffusion of sea water. [16-19] Image (a) was reprinted from reference [20] with permission by the publisher Elsevier. Image (b) was freely downloadable from the web (search with www.google.com, using the images filter). 
The last two mechanisms are triggered when the tissue suffers injury (mainly due to external causes) and, in most cases, are driven by a special class of un-differentiated cells, i.e. the stem cells. On the contrary, tissue renewal occurs during one's natural life and maintains the normal tissue morphology and functions by continuously replacing dead or damaged tissue cells with those newly formed.

\begin{abstract}
Key concept box 1
Bone tissue as one of Nature's best materials.

Bone is a hierarchical structure developing from nano- to macro-meter level.[21, 22] Thanks to this organization, bone can work as internal supporting system which protects organs and offers attachment sites for muscles and tendons allowing locomotion. A crucial component, making bone one of the most enviable engineering materials, is the nano-matrix composed of two phases.[22] From this perspective, bone can be considered as a nano-composite material consisting of an organic framework of fibrils of type I collagen $(\varnothing=2-100 \mathrm{~nm})$, where small inorganic prism-shaped particles of carbonated calcium phosphate apatite are embedded (size $=2-50 \mathrm{~nm}$ ). ${ }^{[22-24]}$ These mineral particles are enriched with trace elements for various metabolic functions (e.g. zinc, fluorine, strontium). ${ }^{[25-29]}$ Dispersed in the bone matrix are other organic components, such as proteoglycans and non-collagenous proteins (e.g. osteocalcin, osteopontin, osteonectin), with essential biological functions. Bone tissue, at higher hierarchical level (i.e. micro-) contains cells, specifically osteoblasts and osteoclasts. The first cellular type is capable of synthesising and depositing new bone matrix, while the latter removes it. ${ }^{[30,31]}$ During bone formation, osteoblasts get entrapped in the matrix they synthesise and transform into osteocytes, ${ }^{[31]}$ which have mechano-sensitivity that plays a role in controlling osteoblast and osteoclast activity. ${ }^{[32-37]}$ Osteocytes communicate with each other and with cells at the bone surface through a system of canaliculi.[36, 37] From a mechanical view, apatite provides bone with stiffness, whereas collagen gives tensile strength and damping abilities. ${ }^{[21,22]}$ As a whole, bone appears as a quasi-stiff but viscoelastic material able to bear both cyclic loads and mechanical impact shocks during lifetime. However, being continuously stressed, bone undergoes micro-fractures that are self-repaired by the body through a process of remodelling. ${ }^{[38]}$ Such phenomenon is mainly triggered by mechanical stimuli provoked by the micro-cracks and driven by osteoblasts and osteoclasts.
\end{abstract}

\title{
1.3. Stem cells
}

Next to differentiated and specialized cells another class of cells exists in the body, i.e. the stem cells. They are un-differentiated cells capable to generate additional undifferentiated lines (i.e. self-renewal potential) and, when required, they can differentiate into various specialized phenotypes triggering natural tissue maintenance, repair and regeneration. Based on their origin, stem cells are divided into embryonic and somatic stem cells. The first class identifies cells present only in the inner mass of the blastocyst during the early embryonic development. Due to their potential to originate all the existing differentiated phenotypes, embryonic stem cells are said pluripotent. ${ }^{[39,40]}$ In later embryonic development stages, such cells give rise to others having more limited differentiation abilities (i.e. multipotent) that compose the three embryonic layers from which all tissues and organs develop. ${ }^{[41]}$ These cells have the potential to differentiate into all phenotypes of a specific tissue, for instance 
bone marrow stem cells can originate all types of blood cells but not cells of different tissues. Derived from multipotent stem cells, unipotent stem cells have even more restricted capacity to differentiate. They can only originate a single type of cells, such as skin cells, and have high proliferation rate to be readily available in case of damage. ${ }^{[42]}$ Somatic stem cells have been identified in many adult tissues, including brain, ${ }^{[43]}$ and have shown to be multipotent (Table 1). These cells lie in specific anatomical locations of adult tissues, i.e. niches, where a balance between various factors (e.g. nutrients, growth and inhibition factors) allows cells to self-renew and maintain their stemness potential during lifetime. ${ }^{[40,44,45]}$ When required, for instance during tissue maintenance or injury repair, particular stimuli are generated in the niche and new signals are produced, which will regulate the differentiation and egression of these cells that later will migrate towards the target site. ${ }^{[46]}$ Usually, somatic stem cells reside in tissues with high renewal rate such as bone marrow and skin, but they are found also in organs like liver and pancreas. Nowadays, it is thought that stem cells exist in all tissues. ${ }^{[47,48]}$ In general, when embryonic and somatic stem cells are stimulated to differentiate, they first lead to cells with little differentiation potential, i.e. the progenitor cells, which will later generate few cellular phenotypes linked to the tissues they are laid in. ${ }^{[4-51]}$ However, recently it has been observed that stem cells have some plasticity, i.e. they may be able to differentiate into cellular phenotypes of a tissue different than the one they reside in. ${ }^{[52]}$ For example, it has been reported that hematopoietic stem cells, as well as neural stem cells and mesenchymal stem cells, may not only originate blood cells, but can lead to skin, liver, brain and heart cells as well.

\subsection{Natural tissue regeneration}

Amazingly, upon injury or amputation, many larval and adult animals can fully or partially regenerate parts of their body, and this potential is higher in less developed organisms. ${ }^{[53]}$ In living beings with high structural organization, e.g. the vertebrates, this capacity is limited to few tissues and organs, while for invertebrates it is impressive. For instance in some planarian worms, e.g. hydra, dugesia and nereis, the regeneration process occurs in a bi-directional modality.[54-56] If they are transected, the head fragment will regrow the tail structure whereas the tail fragment will regenerate a new head (Figure 3 ). Such thrilling regenerative ability in worms is controlled by pluripotent stem cells, i.e. the neoblasts, which can self-renew and differentiate into all the missing cell types, including brain cells, later activating the organogenesis and morphogenesis. ${ }^{[57,58]}$ After amputation of limbs and tail, some vertebrate organisms such as salamanders can fully regenerate them (Figure 3).[54, 56] Briefly, in response to injury the mesenchymal cells of the remnant tissues lose their 
phenotype and de-differentiate into blastemal cells. Such de-differentiated cells then proliferate and later differentiate again into phenotypes capable to synthesize the needed tissues eventually regenerating the whole amputated body parts. Salamanders can regenerate, besides legs and tail, also injured retina and intestine. ${ }^{[52,59]}$ Being unable of blastema formation (i.e. the source of cells for regeneration), larger animals including human beings lost much of their regenerative potential. ${ }^{80]}$ In mammals one of the most exciting example of natural tissue regeneration is given by the liver, which fully regenerates itself when resected. This process is initiated by the tissue removal, when all cells comprising the left intact organ are triggered to proliferate until the reconstruction of the missing parts. ${ }^{[81]}$

Table 1. Overview of stem cells in various body tissues.

\begin{tabular}{|c|c|}
\hline Tissue / organ & Description \\
\hline Bone marrow & $\begin{array}{l}\text { Bone marrow contains two kinds of somatic stem cells, namely } \\
\text { hematopoietic stem cells (HSCs) }{ }^{[60]} \text { and marrow stromal cells (MSCs, called } \\
\text { also mesenchymal stem cells). }{ }^{[61,62]} \text { HSCs are capable to differentiate into all } \\
\text { blood lineages and can regenerate bone marrow after loss. }{ }^{[60,63,64]} \text { MSCs } \\
\text { can differentiate into various cellular phenotypes according to the tissue they } \\
\text { migrate, e.g. chondrocytes if they move to cartilage tissue, osteoblasts if in } \\
\text { bone, myoblasts if in muscle. Besides these, they can generate also } \\
\text { adipocytes and endothelial cells. MSCs move to injured tissues and } \\
\text { participate to their repair or regeneration, but they appear having no role in } \\
\text { tissue homeostasis. }{ }^{[61,62,65-67]} \text { It has recently been proposed to use MSCs } \\
\text { even for lung diseases treatment. }{ }^{[68]}\end{array}$ \\
\hline Liver & $\begin{array}{l}\text { Liver contains stem and progenitor cells that generate oval cells, which then } \\
\text { differentiate into hepatocytes and biliary cells. }{ }^{[69,70]}\end{array}$ \\
\hline Brain & $\begin{array}{l}\text { Neural stem cells (NSCs) allow neurogenesis by giving rise to neurons, } \\
\text { astrocytes and oligodendrocytes. }{ }^{[43,71,72]} \text { However, it is still not clear whether } \\
\text { newly formed neurons in adult brain are integrated into its neural circuits and } \\
\text { thus the purpose of neurogenesis is under debate. }{ }^{[73]}\end{array}$ \\
\hline Skin & $\begin{array}{l}\text { The epidermis has a high renewal rate ( 3-4 weeks) because of its } \\
\text { exposure to the extra-body environment and thus it has to cope with various } \\
\text { stresses, such as exposure to sunlight and substances or friction. Three skin } \\
\text { sites for stem cells have been identified in the epidermis, particularly in } \\
\text { interfollicular area, hair follicle bulge and sebaceous glands. The stem cells } \\
\text { lying in the hair follicle bulge participate to the regeneration of surface } \\
\text { epidermal cells after skin injury. }{ }^{774,75]}\end{array}$ \\
\hline Intestinal epithelium & $\begin{array}{l}\text { The small intestine hosts stem cells able to regenerate its crypts within few } \\
\text { days. }{ }^{76]} \text {. }\end{array}$ \\
\hline $\begin{array}{l}\text { Skeletal and } \\
\text { cardiac muscle }\end{array}$ & $\begin{array}{l}\text { Skeletal muscle myocytes never proliferate. Regeneration of injured skeletal } \\
\text { muscle is assured by satellite cells localized beneath the myocyte basal } \\
\text { lamina, which can differentiate into myocytes when triggered by injury.[77] } \\
\text { The presence of stem cells in myocardium is still nowadays debated and it is } \\
\text { proposed that heart may have progenitor cells having capacity to regenerate } \\
\text { myocardium after small injuries, and that this ability decreases with aging. }{ }^{\left[{ }^{[78]}\right.}\end{array}$ \\
\hline Cornea & The transparency of cornea is maintained by limbal stem cells (LSCs). ${ }^{[79]}$ \\
\hline
\end{tabular}



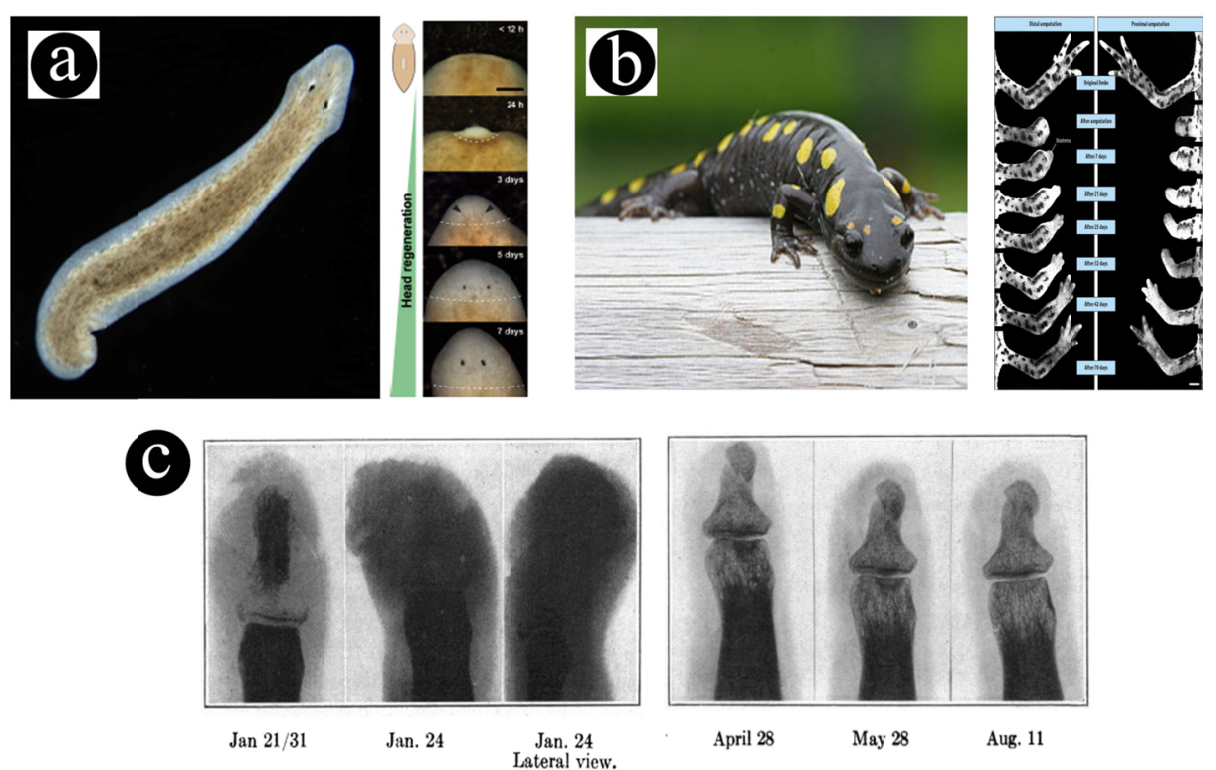

Figure 3. (a) The worm dugesia, which is able to regenerate its head including eyes and brain after resection. (b) Salamanders can fully regrow limbs after amputation. (c) Radiography taken in 1931 of a human tip-finger (male, unknown patient's age), which could regrow after resection. The pictures, from left to right, show the regrowth of bone over time (i.e. from 21 January to 11 August 1931). The picture representing the head regeneration in image (a) was reprinted with permission of the publisher Wiley$\mathrm{VCH}$ from reference [58]. The picture of the dugesia in image (a) and salamander in image (b) are freely downloadable from the web (search with www.google.com, using the images filter), whereas the picture showing the limb growth in image (b) was reprinted with permission of the publisher AAAS from reference [54]. Image (c) was reprinted with permission of the Canadian Medical Association (CMAJ) from reference [87].

It is interesting that when livers from large dogs were transplanted in smaller ones they could decrease in size adapting to the new body size. ${ }^{[82]}$ Vice versa, baboon livers transferred into humans could grow to reach the normal human liver size.[83] Thus, regeneration of the liver is based on a size-dependent cellular proliferation of the existing healthy cells. On the contrary, other tissues such as bone and skin undergo natural tissue regeneration (i.e. remodeling) by recruiting un-differentiated stem cells and guiding their differentiation. In case of serious injuries, in mammals the regeneration of these tissues is less efficient and not capable of complete recovery. ${ }^{[84-86]}$ However, in very rare and unique situations full regeneration of human distal phalanxes (i.e. finger tips) after amputation have been observed (Figure 3), indicating a latent bone regeneration potential in humans. ${ }^{[87,88]}$ Concluding, in mammals tissue regeneration is a process occurring with difficulty in few tissues and relies on the condition that the injury is not too serious and that the tissue matrix is still available in good condition (e.g. tissue with cells still viable and presence of some 
blood vessels). The phenomenon of guiding cellular behavior in the body is the instruction. Nowadays it is believed that the instruction factors for the migration, proliferation and differentiation of cells are of various kinds (see §1.6).

\subsection{Natural tissue repair (i.e. wound healing)}

If injury is serious and results in large damage of the tissue framework, its regeneration is not efficient. Under these conditions, repair by deposition of new matrix components starts and it is more a process patching the tissue up than regenerating. Upon injury, an inflammatory reaction is triggered to limit the damage while blood vessels restrict to stop bleeding. During this stage, quick hematoma formation is initiated leading to a clot. Fibroblasts and inflammatory cells (i.e. macrophages, monocytes, lymphocytes and polymorphonuclear cells) infiltrate the site attracted by ligands secreted by the clot and surrounding healthy tissues. In the meantime endothelial cells of damaged vessels release angiogenic growth factors in the interstitial fluids that diffuse throughout the surrounding tissues. This prompts quiescent endothelial cells of health vessels to migrate towards the damaged site, where they proliferate and generate new capillary networks to connect with those healthy. ${ }^{[89-91]}$ Afterwards, blood flow in the newly formed capillaries transports and extravasates nourishment in the interstitial fluids, which spread them in the defect. ${ }^{90}$, 92] Such molecules encourage the proliferation and migration of fibroblasts that reconstruct the damaged tissue by synthesizing new matrix, ${ }^{[56]}$ which leads to scar formation. Although normal scar provides a stable restoration of the tissue, it has inferior structural and functional characteristics. It is believed that in mammals wound repair is evolutionally optimized for a quick healing under difficult conditions, where rapid inflammatory response prevents infection. ${ }^{\left[{ }^{93,}, 94\right]}$ Depending on the tissue and the injury seriousness, remodeling after scarring may occur to adjust the structure of the repaired tissue and optimize its performances. This last process often occurs after skin or bone tissues repair, where elasticity (skin) and mechanical properties (bone) may be partially recovered.

\subsection{Instructive factors in tissues}

Cells expose on their surfaces receptors that are able to bind specific molecules, i.e. the ligands, present in the tissue framework. The binding of a signalling molecule to a cellular receptor triggers intracellular pathways that will eventually result in changes of the gene expression affecting in this way the cell behavior. By virtue of the source of the ligand, three different mechanisms exist, namely autocrine, paracrine and endocrine signalling. ${ }^{[95,96]}$ In the first, cells just react to signalling molecules they themselves secrete and this mechanism happens, for instance, during liver 
regeneration and cancer proliferation. Paracrine signalling occurs when cells of different types secrete the ligands, which diffuse towards the nearby target cells and bind to their receptors. This mechanism is common, for instance, during connective tissue repair, where macrophages secrete cytokines pushing fibroblasts to proliferate and synthesize new matrix. Sometimes, e.g. during inflammation reactions, endocrine organs produce biomolecules that, via the blood and lymph streams, reach and affect distant target cells. In natural tissues, the cellular fate is driven by a number of proteins, i.e. the growth factors, which promote various cellular phenomena controlling the health of tissues (Table 2). Further to biochemical instruction, it has been reported that physical stimuli from the surrounding micro-environment can influence cellular behavior as well. For instance, in addition to its role as a molecule transporter, the interstitial fluid flow in tissues mechanically acts on fibroblast and smooth muscle cells promoting their motility ${ }^{[97]}$ and it has been suggested inducing fibroblasts to proliferate and differentiate into contractile myofibroblast in vitro. ${ }^{[88]}$ Interestingly, fluids can also induce osteocytes to secrete molecules that later trigger bone remodeling (see the key concept box 2). From here, a possible role of the flow of fluids in inducing muscular tissue regeneration is seen. In vitro studies have shown that the stiffness of polymeric substrates can instruct cultured marrow-derived mesenchymal stem cells to differentiate into either a neuronal, myoblastic or osteoblastic lineage. ${ }^{[99-104]}$ As the body tissues vary in their structure (e.g. brain tissue offers softer structure than bone), it is plausible that the stiffness of the interstitial matrix may control in vivo the fate of stem cells. Other instructive signals that cells can perceive might be the forces caused by the cellular binding to the interstitial matrix through different molecules (e.g. fibronectin and vitronectin), ${ }^{[105]}$ or the topography of the tissue (e.g. orientation of the fibers in interstitial matrix may induce stem cells to differentiate into cells having certain polarity, such as myoblasts). ${ }^{[105-107]}$

\subsection{When the body fails - aiding tissue regeneration and repair}

Largely injured tissue environments may lose their instructing properties and, without adequate or sufficient stimuli, stem cells may not be able to regenerate or repair the tissue. This may happen, for example, in myocardial tissue after infarction ${ }^{[84]}$ or in bone defects where large quantities of tissue are missing (i.e. critical sized bone defects). ${ }^{[85,86]}$ In such situations there is need of external intervention to support the cellular activity with stem cells or gene therapies, by grafting with healthy harvested tissues and organs (i.e. auto- and allografts) or biomaterials. 


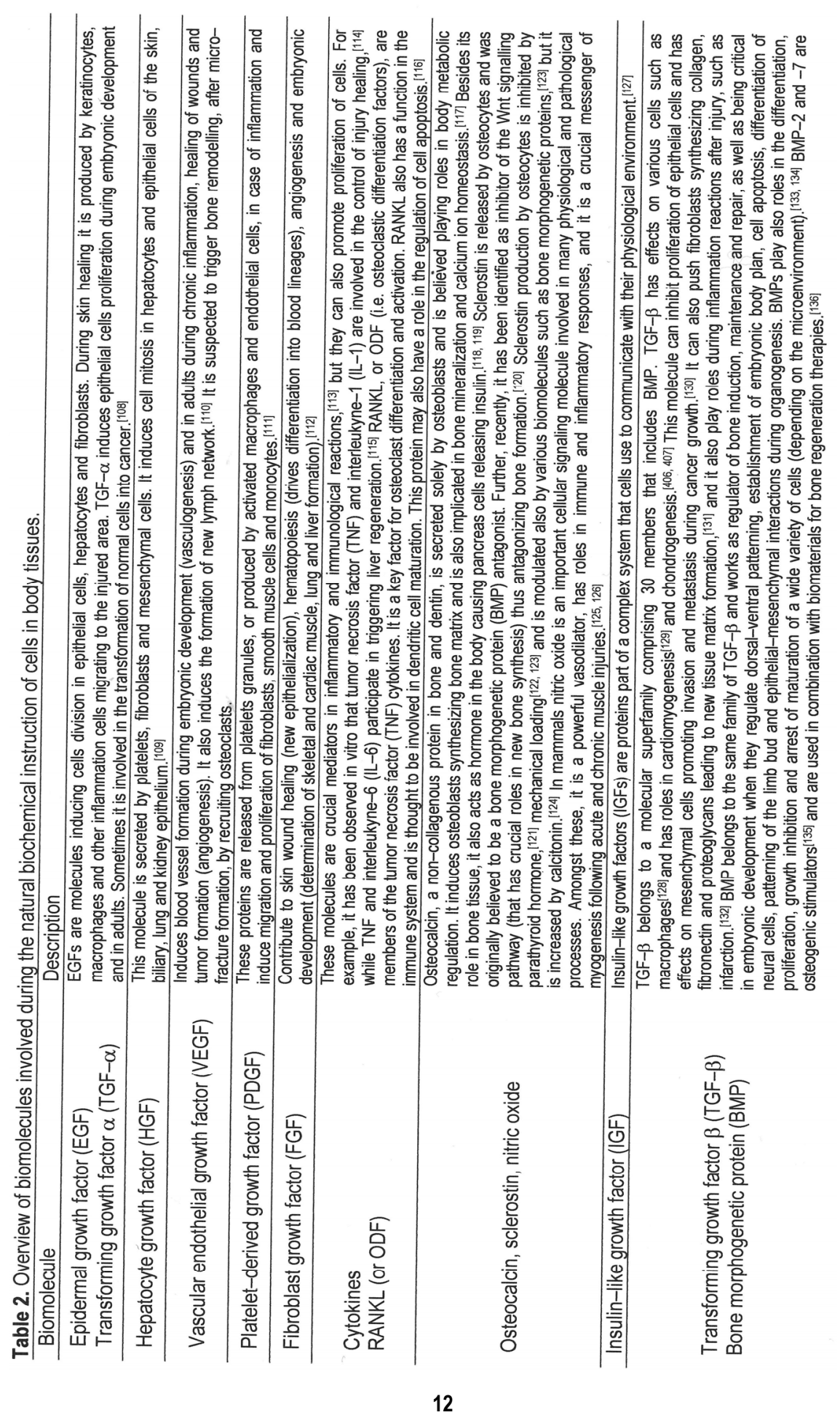




\section{Key concept box 2 \\ Instructive signalling in bone tissue self-regeneration (or bone remodeling).}

Osteocytes are able to perceive mechanical pressures and loads acting at the surface of bone.[32-35] It is hypothesized that such external stimuli induce interstitial fluid flow along the canaliculi, and consequently provoke shear stresses that deform the osteocyte membrane.[36, 37] In response to these stimuli, osteocytes modulate the secretion of many molecules, e.g. insulin-like growth factors (IGF), osteocalcin, sclerostin, nitric oxide, RANKL, TNF-related cytokines and osteoclasts differentiation factors (ODF). Such molecules are transported by interstitial fluids towards the bone surface, where they influence on the cellular activity of surface cells, i.e. osteoblasts and osteoclasts, triggering bone remodeling (i.e. paracrine effect).[34-37] Through this process, osteocytes allow bone tissue adapting to external mechanical stresses by inducing osteoblasts to synthesize new bone matrix when there are increased loads, or inducing osteoclasts resorbing tissue when there is a decreased use of the bone. ${ }^{[34-37]}$ Other physical triggers for remodeling are the micro-cracks that form in bone tissue due to continuous stresses during life. ${ }^{[137,138]}$ In such scenario, osteocyte apoptosis occurs in proximity of the cracks. ${ }^{[139-141]}$ It is believed that dying cells send signals to the surrounding healthy osteocytes, which later secrete the aforementioned signaling molecules and influence on the surface cells that are triggered to repair the crack. ${ }^{[140,141]}$

In the 1990s, gene therapy was proposed as an exciting and novel approach aiming to transfer genetic material or biomolecules (e.g. growth factors) towards one's target cells/tissue to cure a disease or improve the patient's healthy. Gene therapy is based on the concept of using viruses (i.e. adenoviruses, retroviruses and lentiviruses) as

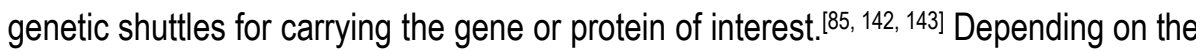
nature of the viral genome, such vectors can be RNA- or DNA-viral vectors. Unfortunately, after the death in 1999 of a patient treated for ornithine transcarbamylase deficiency (i.e. a rare metabolic urea cycle disorder) and other issues with immunogenicity, carcinogenicity and vector manufacturing many physicians and scientists lost hope for gene therapy. ${ }^{[144]}$ However recently gene therapy gained interest again in fields such as ophthalmology, where it appears promising for the treatment of retinal diseases. ${ }^{[145]}$ Although the ideal genetic delivery vehicle has not been found, this approach holds lot of potential, especially with single-gene problems, and therefore is still being actively investigated.

Stem (or differentiated) cells therapy is the process where new cells are introduced into a damaged site. For this purpose, either stem or differentiated cells are harvested from the patient and expanded in laboratory. After proliferation, they are injected back in the patient (i.e. autologous stem cell therapy), either in blood stream or directly in the injured sites. This strategy may also use, with some risks, cells from different individuals (i.e. allogeneic stem cell therapy) or embryonic stem cells. Example of therapies, either clinically used or still under investigation, are the use of bone marrow stem cells to treat pancreas cancer, ${ }^{[146]}$ and leukemia, ${ }^{[147]}$ and stem cells have been proposed as possible future therapy to fight Fanconi anemia, a bone marrow failure syndrome. ${ }^{[148]}$ Currently new applications, such as in neurology and cardiology fields, are under investigation. ${ }^{[149,150]}$ However, despite of its potential this technique is not 
much cost-effective due to the processing and may have ethical issues when embryonic stem cells are used.

Grafting with one's own healthy tissues (i.e. autograft) is a procedure involving harvest of tissue from the patient itself and transplantation into a different site. It is often used to fill bone defects during orthopedical surgeries where the most common harvesting site is the hip. This method is nowadays considered the gold standard in tissue repair but may lead to donor-site morbidity and has limited tissue availability. ${ }^{[151]}$ Grafting with tissues and organs from donors (i.e. allograft) is also possible and examples are heart and kidney transplantation, but it is a procedure having disease transfer and immunogenic risks. ${ }^{[151]}$ To overcome the problems of the 'fully' biological procedures, grafting with biomaterials may be a valid alternative.

Traditionally, biomaterial grafting consisted of providing the damaged site with a passive framework for cells, which just replaced the missing tissue. The need for full tissue regeneration is nowadays driving towards new biomaterials designed to actively interact with the biological surroundings and eventually instruct cells to perform in certain ways. It has been observed that, when stem cells attach to a biomaterial, the local surface characteristics (e.g. topography, roughness, surface stiffness and chemistry) can induce various cellular behaviors. For example microand nano-rough surfaces can physically promote the adhesion of cells offering many contact sites for their filopodia. ${ }^{[152]}$ Further, such surfaces, having large surface area, can expose functional groups capable of binding specific proteins from surrounding body fluids. In this way, cells are favored to contact with the materials, on which different adsorbed protein motifs may trigger various intracellular signalling pathways influencing on the cellular responses, including their differentiation. ${ }^{[103,153,154]}$ Currently, such an active biomaterials approach seems more practicable and cost-effective than gene and stem cells therapies and has no ethical issues. As compared to tissue grafting, biomaterials have, in principle, unlimited availability and no immune response risks.

Two science fields born during the last century with challenging dreams are regenerative medicine and tissue engineering, which both aim to improve the health and quality of life of people by restoring, maintaining, or enhancing tissue and organ function. Regenerative medicine mainly focuses on (stem) cell therapy methodologies, whereas tissue engineering is a more multidisciplinary field involving biology, medicine, materials science and engineering. It involves the use of a combination of cells, engineering and materials, including suitable biochemical (e.g. growth factors) and materials (e.g. active surfaces) factors. For example, recently tissue engineered bladders were successfully implanted in patients. In this study, urothelial and muscle cells were extracted from each patient's bladder biopsy and 
grown in culture. Afterwards they were seeded on biodegradable collagen-based bladder-shaped scaffolds. Seven weeks after biopsy, the autologous engineered bladders were implanted to reconstruct the patients' bladders. ${ }^{[155]}$ Another recent and surprising success of tissue engineering involves the respiratory system. In this case, a decellularized human donor trachea was seeded with epithelial cells and mesenchymal stem-cell-derived chondrocytes previously harvested from a patient affected by bronchomalacia and cultured in vitro. This graft was then implanted to replace the defected bronchus. ${ }^{[156]}$

\subsection{Designing active biomaterials to instruct cells - inspiration from nature}

Nature uses amazing strategies to overcome many problems mankind is always grappling with, such as improved health quality, fast and safe transportation and many others. Biomimicry, i.e. taking full or partial inspiration from nature, has been the core of many technological ideas (Figure 4) and is nowadays driving scientists towards new thrilling inventions. For example, the gecko can proudly walk on vertical and inverted surfaces thanks to its feet's structure, which strongly adhere to surfaces through a combination of van der Waals and capillary forces. [157-161] Inspired by gecko, scientists designed glue-free tapes based on carbon nanotubes ${ }^{[162]}$ and elastomer micro-patterns. ${ }^{[163-165]}$ Such tapes are able to hang heavy objects onto dry and wet surfaces without detaching or breaking and have been proposed as wounds sealers or surgical sutures and staples. Another natural model has been the Ostracion cubicus (i.e. box-fish) that, despite its large body, is surprisingly slick and can swim fast with little energy cost. ${ }^{[166,167]}$ From this fish, Mercedes-Benz developed a car with a funny design, which has one of the lowest coefficient of drag ever tested and low fuel consumption. ${ }^{[166,168]}$ Whale fins suggested researchers how to design improved paddles for energy wind turbines, ${ }^{[169]}$ gaining in green energy production performances. Japanese engineers, to reduce the noise provoked by a high-speed train when exiting from tunnels, were inspired by a weird-looking bird, the kingfisher. The front of the train was re-designed looking at the beak of this bird. This cunning led to a train capable of silently travelling with reduced energy consumption. ${ }^{167]}$ As last example, George de Mestral observed how strongly burdock stuck to the fur of his dog. Pushed by his curiosity, he observed these burrs and discovered their small hooks that later inspired him developing Velcro ${ }^{\mathrm{TM}}$, a tear-fastener widely used in many applications, including space suits. ${ }^{[166]}$ Biomimicry has been applied also in medical sciences since immemorial time. The Aztecs and Egyptians treated fractures by realigning the parts and trying to join them by the insertion of metal sticks into the medullary canal (Figure 5), such as the iron leg prosthesis found in the mummy of priest Usermontu (656-525 BC). ${ }^{[170]}$ Other ancient examples are the glued 
linen- and wood-based toe substitutes on Egyptian mummies dating back to 600 $300 \mathrm{BC}$. $[171,172]$ In these cases, shape and mechanical biomimicry was applied to partially retrieve the lost mechanical functions of the leg and foot. In modern times, mimicking the shape of body parts to restore or adjust mechanical malfunctions has been applied in the design of synthetic cardiac valves ${ }^{[173]}$ and hip prostheses with femoral stem ${ }^{[174]}$ (Figure 5).

More recently, with the beginning of the 'active biomaterials' age for tissue regeneration, new biomimicry strategies have been proposed and pursued. As mentioned earlier, the tissue matrix instructs cells in various ways and researchers have striven to mimic it attempting to control cell fate and thus tissue regeneration. Interstitial matrix and basement membranes offer many micro- and nano-sized topographical features, which are sensed by cells. ${ }^{[175-177]} \mathrm{An}$ example is the random and complex weaving of collagen filaments composing the tissue framework. ${ }^{[178]}$

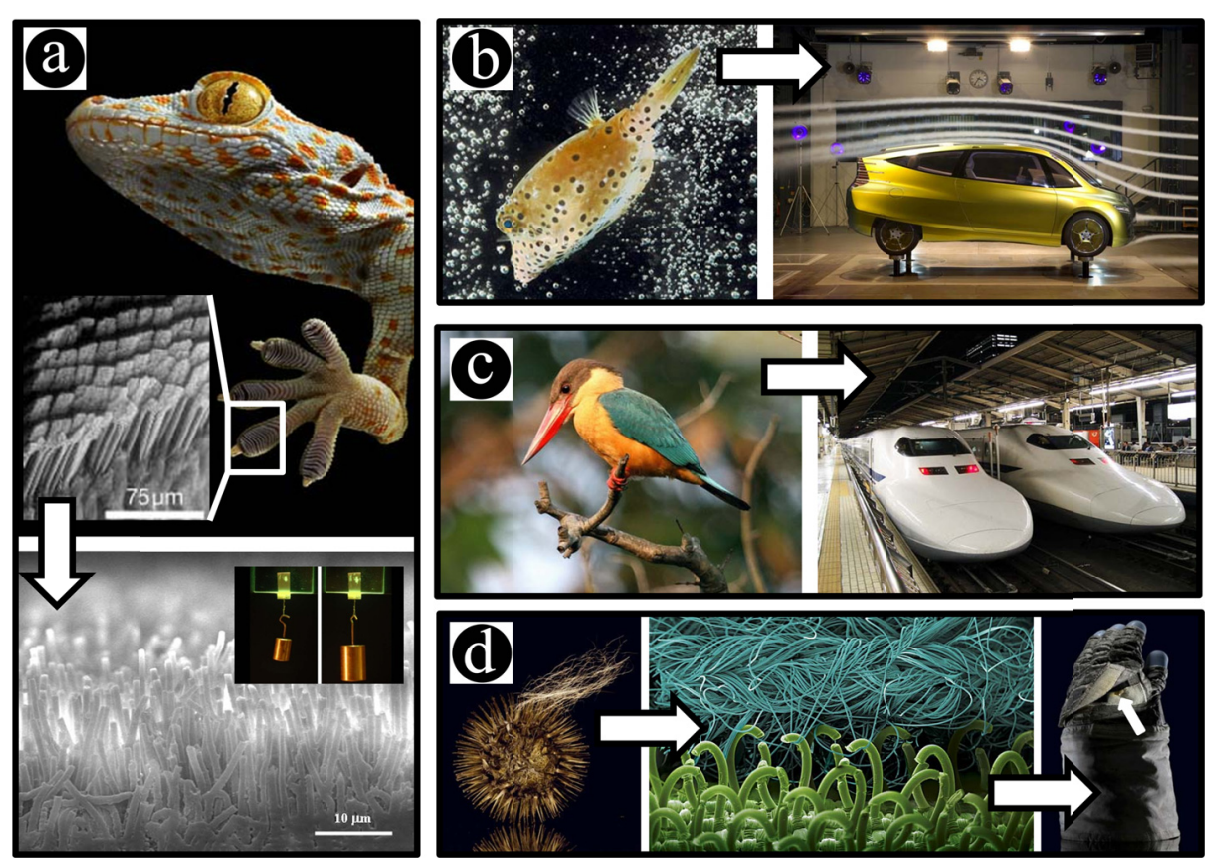

Figure 4. (a) Biomimicking the nano-structure of gecko feet, strong adhesive able to hang heavy objects without use of chemical glues could be made. (b) The box-fish inspired the design of a low fuel consumption car. (c) The snout of Japanese fast trains resembles the kingfisher beak. (d) Velcro ${ }^{T M}$ was designed thanks to burdock's hooks and is nowadays used even for spatial clothing. The pictures of the animals in (a), (b) and (c) are freely downloadable from the web (search with www.google.com, using the images filter). The micrographs of gecko feet in (a) and the train in (c) are also freely downloadable from the web. The images of the car (b) and VelcroTM (d) were reprinted with permission of the National Geographic magazine [166]. 
Mainly, the interactions between cells and surface occur through contact guidance, a locomotor response of cells depending on the surrounding environment micro- and nano-characteristics given not only by the tissue matrices ${ }^{[179]}$ but also by the presence of other cells. ${ }^{[180]}$ In mid 1990s it has been shown that almost all mammalian cells respond to the tissue topography activating different cellular behaviors. ${ }^{[181-198]}$ For example, various experiments showed that cells adhere onto nano-grates and align along the direction of the grating. When human fibroblasts were seeded on silicon gratings with heights ranging from 50 to $600 \mathrm{~nm}$, they aligned according to the direction of the grooves with an increased response to deeper gratings. At the same time, to such increased alignment corresponded decreased cell area and proliferation. [185] Human endothelial cells had more pronounced alignment on $600 \mathrm{~nm}$ deep gratings as compared to flat surfaces, and could organize into aligned cellular superstructures. Likewise to fibroblasts, endothelial cells had lower proliferation with the increase of the groove depth. ${ }^{[186]}$ Human embryonic and mesenchymal stem cells, bovine smooth muscle cells and human corneal cells aligned and proliferated on nano-gratings as similarly as fibroblasts and endothelial cells. ${ }^{[187-190]}$ Interestingly, human mesenchymal stem cells preferentially differentiated into neuronal phenotype when contacting with ordered nano-gratings. ${ }^{[191]}$ Surfaces presenting nano-pits andposts, in general, elicit diminished initial adhesion depending on the cellular phenotypes. For instance, human osteoblasts cultured on polycarbonate surfaces having $300 \mathrm{~nm}$ pits had reduced adhesion as compared to smooth surfaces, ${ }^{[192]}$ as well as human fibroblasts negatively responded to increasing depth pits. ${ }^{[193]}$ On the contrary, poly (L-lactide) surfaces with 400 to $700 \mathrm{~nm}$ posts could elicit increased adhesion of human fibroblasts, but lower proliferation.[194] Pits with $100 \mathrm{~nm}$ depth induced human mesenchymal stem cells differentiating into an osteogenic lineage, ${ }^{[195]}$ and could allow constant filopodia formation of human bone marrow cells. ${ }^{[196]}$ Various studies reported also different responses to combinations of geometrical, dimensional and chemical characteristics. For instance, the topographical disorder degree has shown to affect the fate of human mesenchymal stem cells, particularly on their differentiation paths. On highly ordered pits, these cells had fibroblasts-like morphology, while with the increase of pit disorder they increased their osteoblastic character with increasing expression of osteogenic proteins. ${ }^{[195]}$ When the same stem cells were cultured on substrates having different stiffness, those adhering on soft posts differentiated to adipogenic cells whereas rigid surface led to osteoblastic phenotype. [197] Recently, applications of various nano-topographical structures inspired from nature have been proposed also with human retinal pigment epithelial cells for ophthalmic tissue regeneration. ${ }^{[198]}$ To conclude, mimicking the tissue surface nano-features with biomaterials might be a powerful way to handle cellular fate and 
thus to control tissue regeneration. Other strategies involve mimicking the surface chemical composition in combination with its topography. For example, bone surface chemistry and roughness were imitated by letting calcium phosphates precipitate from ultra-saturated solutions (e.g. concentrated simulated body fluids) onto the surface of polymer-, peptides sheets- or graphene-based bulks. ${ }^{199,}$ 200] Further methods to control cells include mimicking the hydrated three-dimensional structure of natural (soft) tissue matrices using hydrogels, whose tailoring allows designing scaffolds with various properties. Hydrogels are polymeric materials able to swell in the presence of aqueous fluids maintaining their three-dimensional network structure by virtue of chemical crosslinks. ${ }^{[201]}$ In general, hydrogels have good biocompatibility and can homogeneously incorporate cells, growth factors and other bioactive compounds while allowing rapid diffusion of nutrients and metabolites.
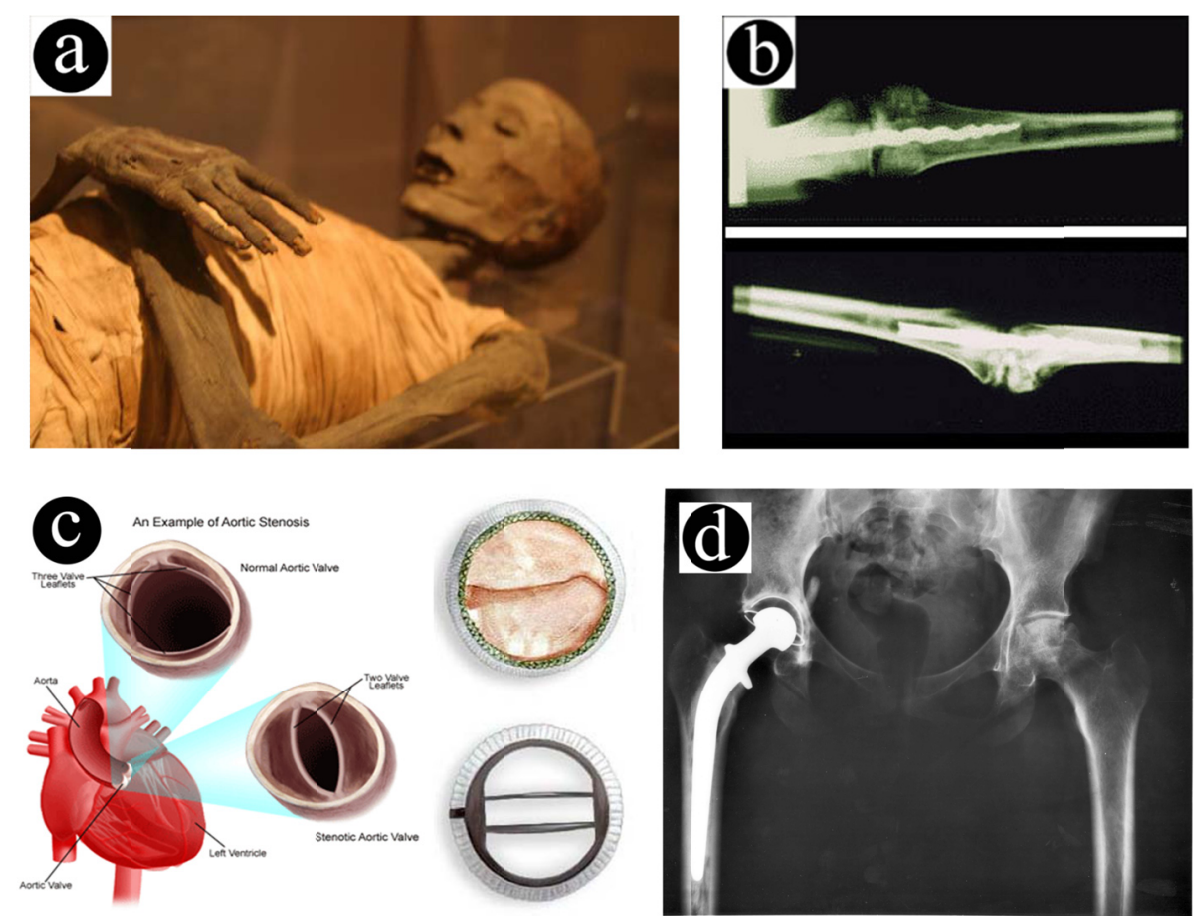

Figure 5. (a) The Egyptian mummy of priest Usermontu. (b) Radiography of Usermontu's leg showing the iron stick inserted in the attempt of recover the walking function of the leg. (c) An example of modern biomechanical mimicry in case of aortic stenosis: man-made heart valves can be obtained using porcine valves (top) or making a fully synthetic one (bottom). (d) Radiography of a modern hip prosthesis. It can be seen that shape mimicry has been done to retrieve the lost function of the injured hip, in particular the prosthesis replaces the femora head and stem. All images are freely downloadable from the web (search with www.google.com, using the images filter). 
All these properties led to the hope of obtaining scaffolds for aiding regeneration of soft tissues. For instance, a hydrogel containing collagen peptide and human mesenchymal stem cells was developed to mimic the hydrated matrix of cartilage. Being chemically and structurally similar to cartilage, it instructed cells favoring their chondrogenesis and allowed the synthesis of new typical cartilaginous matrix. ${ }^{[202]}$ Similarly to hydrogel, to mimic the fibrous tissue networks it has been proposed to produce matrices of polymer micro- or nano-fibers by electrospinning. This technique allows controlling many parameters such as the fiber diameter and their weaving, as well as it permits working also with natural polymers such as collagen. In this way a structural and chemical biomimicry of tissue frameworks may be accomplished.[203-206] For instance, mesenchymal stem cells were cultured on collagen type I electrospun scaffolds with various fiber diameters and they osteogenically differentiated.[204] Electrospun scaffolds have been proposed for many applications in regenerative medicine, including dura mater repair, nerve regeneration, tendon and ligament repair, bone and blood vessel repair. ${ }^{[207]}$ Hydrogels and electrospun fibrous matrices may elegantly mimic the physicochemical and topographical features of the body tissue matrices, but they do not present or guarantee similar mechanical performances as those in natural tissues. To overcome this problem, rapid prototyping techniques exist and provide synthetic frameworks having a wide range of mechanical properties with controlled macro-shape, interconnected pores and the presence of ultra-porosity. These scaffolds could support human mesenchymal stem cell adhesion, proliferation and spreading forming bridges between fibers. Further, when chondrocytes were used, the formation of cartilaginous-like tissue occurred.[208, 209] However, this methodology is not immune from drawbacks. For example, it still cannot provide frameworks with nano-dimension features, which is the level at which most of biological phenomena occur. Immobilizing bioactive molecules, such as those present in tissues, onto the surface of biomaterials has been proposed as different way to mimic the instructive characteristics given by signalling molecules dispersed in the natural environments. In this case adult stem cells would be provided with biochemical signals promoting their adhesion and eventually driving their fate. For example, immobilized fibronectin on the surface of polymers favored the cellular adhesion, ${ }^{[210]}$ while the presence of bone morphogenetic proteins and laminin may induce stem cells differentiating into osteogenic and neural phenotypes respectively. $\left.{ }^{211}, 212\right]$ This method, if combined with mechanical load-bearing synthetic scaffolds, may represent a powerful tool for body tissues regeneration. Some tissues, such as bone, have a matrix composed by two or more chemically and physically different phases. By virtue of this, various composite materials have been developed to mimic the multiphase characteristic of tissues. In this way newly 
developed materials may offer, besides instructive cues, also mechanical characteristics close to those of the considered tissue. For example, the natural intrafibrillar collagen mineralization, which occurs during bone tissue development, has been replicated in vitro to produce composite materials that chemically and hierarchically mimic the bone tissue. ${ }^{[213]}$ Other groups successfully mimicked the macro-structure of bone obtaining similar mechanical strength by producing macroporous blocks with silk fibers and calcium phosphate.[214]

\subsection{Instructive biomaterials for bone tissue regeneration}

In bone tissue regeneration a subgroup of instructive biomaterials exists that have osteoinductive potential. These materials, following injury and colonization of inflammatory cells ${ }^{[215,216]}$ are capable of inducing stem cell differentiation into osteogenic phenotypes. ${ }^{[217-220]}$ This has been demonstrated in implantation sites where bone is normally not present (e.g. muscle, skin) without the support of exogenously added bone growth factors or (osteogenic) cells (Figure 6).[86] Since the Sixties, when osteoinductivity of biomaterials was observed for the first time in a polymer, ${ }^{[221]}$ this process has been reported for various materials, mainly sintered calcium phosphate ceramics, ${ }^{[222-228]}$ but also in calcium phosphate cements, ${ }^{[229,}$ 230] coatings, $[231,232]$ porous Bioglass ${ }^{\mathrm{TM}},{ }^{2233]}$ surface-treated titanium. ${ }^{[234]}$ More recently, bone induction was shown also in a composite of hydroxyapatite and polylactide.[235] So far, under certain physicochemical characteristics it seems that all types of materials can potentially be osteoinductive. Although the process underlying bone induction by these materials has not yet been fully elucidated, ${ }^{[86]}$ numerous hypotheses have been formulated to explain it. For example, surface microstructural features such as grain and micro-pore size have been shown to play a crucial role in several studies. When hydroxyapatite $(\mathrm{HA})$ with and without micro-structured surface was implanted in muscles of dogs, only those possessing micro-structure could induce ectopic bone formation. ${ }^{[236,237]}$ Similar results were shown in studies where HA and biphasic calcium phosphate (BCP) ceramics with various micro-porosities were compared.[228] Thus the surface structure and, to a lesser extent, the chemistry have been proposed as key actors in osteoinduction since they may control (specific) protein adsorption and may also induce an inflammatory response that eventually lead to bone formation. More detailed description of the current hypotheses on osteoinduction-related phenomena will be given in $\$ 1.10$. When used for the repair of critical sized bone defects (e.g. $17 \mathrm{~mm}$ diameter in goats), micro-structured osteoinductive calcium phosphate ceramics have shown high bone forming potential, ${ }^{[86]}$ superior to non-osteoinductive ceramics. ${ }^{[238]}$ Further, recently these 
materials have demonstrated to be a promising synthetic alternative to autologous bone grafting, ${ }^{[86]}$ demonstrating the clinical importance of osteoinductive materials. However, the inherent brittleness of such calcium phosphates, or the excessive stiffness of titanium materials, still limits their application in load-bearing sites, indicating a role for mechanically improved materials such as osteoconductive and, possibly, osteoinductive composites. Particular attention has been paid on introducing calcium phosphates into synthetic polymers, such as polylactide and its copolymers, to obtain composite materials that could mimic the mechanical properties of bone and, at the same time, trigger the typical bone tissue regeneration.
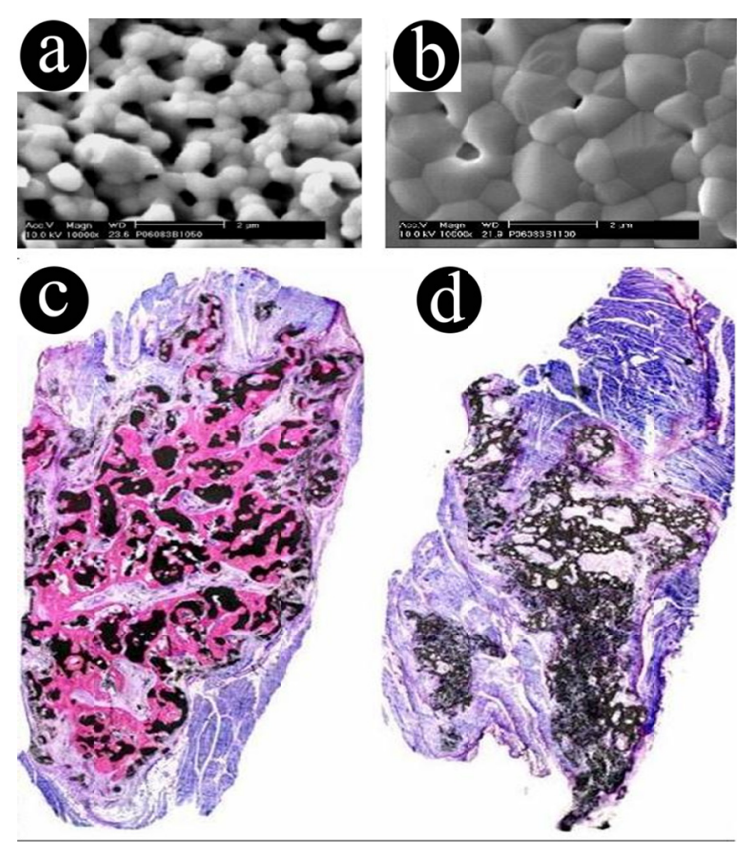

Figure 6. SEM images of (a) micro-structured surface of a tricalcium phosphate ceramic (i.e. TCP) and (b) dense surface of a chemically identical ceramic (i.e. TCP). Only the micro-structured TCP could trigger abundant heterotopic bone formation after 12 weeks in muscle of dogs (c) whereas dense TCP did not (d). The histology staining is methylene blue/basic fuchsin where bone is pink, soft tissues are blue or dark violet and TCP granules are black. Images are a courtesy of dr. Yuan H (Xpand Biotechnology BV, Bilthoven, the Netherlands).

Several studies have shown that adding (nano-) hydroxyapatite particulate or fibers into polylactide materials can improve the mechanical properties of the material.[239, 240] Furthermore, it was reported that the addition of high contents of hydroxyapatite can render the material osteoconductive.[241] The presence of hydroxyapatite particles has further shown to increase protein adsorption and enhance osteoblast adhesion.[241-243] Besides improving the mechanical characteristics of osteoinductive materials, 
particularly ceramics, surgeons are increasingly demanding for instructive biomaterials with improved mouldability. Such materials should allow surgeons to easily and quickly fit them in the defect with the guarantee of their instructive characteristics and initial stability in the site. For this purpose, materials in the form of putties and injectable pastes have been developed. [244]

\subsection{Current hypotheses on the biomaterial-related osteoinduction}

Heterotopic bone formation in micro-structured ceramic materials has been proposed to be related to their large surface area and to a combination of resulting natural phenomena occurring at the interface between biomaterials and biological environment such as surface mineralization and protein adsorption.

Spontaneous surface mineralization is a process where carbonated apatite precipitates from the surrounding (body) fluids onto the surface of materials forming nano- and micro-structured layers. ${ }^{245,246]}$ It is hypothesized that this process is enhanced in presence of surfaces containing calcium phosphate-based components because, upon contact with body fluids, they dissolve releasing calcium and phosphate ions that increase the local body fluid supersaturation causing precipitation of carbonated apatite. However, surface mineralization has been observed also in materials that did not contain calcium phosphate such as in only one polymer, i.e. polyHEMA, ${ }^{[221]}$ and surface-treated titanium. ${ }^{[234]}$ In these cases the presence of specific functional groups on the surface may have acted as nucleation sites for the spontaneous precipitation of mineralized layers. It is in fact hypothesized that such sites are able to attract calcium, phosphate and carbonate ions from the surrounding fluids. ${ }^{[245]}$ In vivo apatite formation can be reproduced, at physiological $\mathrm{pH}$ and temperature, in a simulated body fluids (e.g. like $\alpha-M E M$ or SBF) with ion concentrations nearly equal to those of human blood plasma.[247] This provides an indication of the in vivo surface mineralization potential of a material by evaluating the apatite formation on its surface in such simulated body fluids. Various experiments have correlated in vitro surface mineralization with in vivo heterotopic bone formation. For example, the in vivo osteoinductivity of titanium implants, with surfaces that did or did not mineralize in vitro, was evaluated and the results showed that the implants able to form apatite layers in vitro also induced bone formation in vivo. Conversely, those that did not mineralize in vitro also did not induce bone formation. ${ }^{[234]}$ For a series of reasons, in vivo surface mineralisation is believed to generate suitable conditions allowing cells to form bone. ${ }^{[234,248,249]}$ The nano- and micro-scaled structure of the precipitated apatite layers, by virtue of its larger surface area, can expose more binding sites for biomolecule adsorption. In particular, body fluid molecules having affinity to calcium, such as vitronectin and bone morphogenetic 
protein, may be attracted and favour the adhesion and differentiation of stem cells into osteogenic lines. ${ }^{[153,250]}$ Further to this, surfaces presenting nano-topography may physically favour cellular adhesion by offering many adhesion sites for cells. ${ }^{[152,}$ 195] Thus, surface mineralisation may play an important role as it would not only offer nano-rough surfaces for the anchorage of cellular filopodia, but may also determine the kind and the amount of adsorbed proteins that will influence on the cellular fate.

The importance of protein adsorption in inducing ectopic bone formation is still nowadays debated and few studies have tried to analyze its role. It has been reported that bioinert aluminum oxide ceramics adsorbed proteins and induced bone formation in muscle of dogs while they did not surface mineralize either in vitro or in vivo. [251, 346] Another aspect regarding inductive bone formation may be ion release, especially calcium and phosphate, from the implants. Calcium is believed to be an extra-cellular signalling molecule in bone ${ }^{[226-228,252]}$ and, together with phosphate ions, ${ }^{[253]}$ it may not only enhance the surface mineralizing potential of materials but also (possibly) affect the proliferation, differentiation and mineralization of osteogenic cells ${ }^{[252,321-323] \text {. }}$

The initial inflammatory response to the implantation of biomaterials has been proposed triggering osteoinduction as well. In particular, injury due to implantation causes inflammation and invasion of the material by macrophages that would secrete cytokines, like prostaglandin E2, provoking the differentiation of stem cells into osteogenic-line. ${ }^{[217]}$ Histological observations over time demonstrated that, upon implantation of ceramics, fibrous tissue containing monocytes and macrophages invaded the implants at early time points, while later bone formed tight to the material and active osteoblasts were aligned with the newly synthesized bone.[218-220] Interestingly, the micro- and nano-texture of the surface can influence on the intensity of the in vivo inflammatory response. ${ }^{[254]}$ Particularly, the secretion of cytokines such as interleukin-6 (IL-6) was enhanced when macrophages were cultured on materials having micro-textures compared to smooth surfaces. ${ }^{[255]}$ It was also shown that the presence of IL-6 enhances the expression of osteogenic markers (e.g. alkaline phosphatase and osteocalcin) from osteoblasts. ${ }^{[256]}$ Thus, macrophages can secrete various cytokines and angiogenic molecules, ${ }^{[257]}$ participating in new blood vessels formation and also contributing to the differentiation of stem cells into osteogenic lines which will lead to bone matrix synthesis.

Concluding, still today the causes of materials-related osteoinduction and its mechanisms are under debate but their potential as promising instructive biomaterials for bone tissue regeneration already loomed up on the horizon. 


\subsection{Rationale and aims of the thesis}

Based on the aforementioned introductory review, it can be said that guiding the regeneration of injured body tissues might be possible through the control of various material parameters that eventually instruct cells. In particular, biomaterials should actively interact with the biological surrounding evoking a cascade of specific phenomena that will lead to the full regeneration of the required tissue. In bone tissue regeneration, the most promising instructive materials (i.e. micro-structured calcium phosphate ceramics) already showed their tissue regenerative potential but can only be used as fillers for bone voids where no mechanical stresses act. Therefore for bone regeneration in load-bearing sites, the sole instructive characteristic may not be sufficient. Designing materials that, besides controlling cellular fate in vivo, also have improved mechanical performances is a key request. Further, most calcium phosphate ceramics are prepared in block or particulate forms making their handling properties not optimal with risks of incomplete defect filling or granule dispersion during surgery. Consequently, developing bone instructive materials with improved handling properties would be desired. Combining polymers with calcium phosphate granules or powders has been suggested as possible solution to have improved biomaterials that might be used in bone sites, either with or without mechanical stresses. For these reasons, many groups have already proposed moldable putties of calcium phosphate granules with polymeric gels, or composites of hydroxyapatite with either degradable and not polymers. However, to the best of our knowledge, none reported or studied the impact of polymer and calcium phosphate phases on the instructive properties of the resulting composites. Therefore, the objective of this thesis was to evaluate the influence of polymer and calcium phosphate phases when designing instructive composite materials for bone tissue regeneration.

\subsection{Outlines of the thesis}

The effect of polymer gels on the osteoinductive potential of calcium phosphate granules in putties and injectable pastes is studied in Chapter 2, which is based on the assumption that fast dissolution and clearance of the gel is a crucial factor. Thereafter, Chapter 3 introduces a pilot study on the feasibility to design osteoinductive composites. This Chapter puts the basis for further studies on the effects of manufacturing methods and choice of polymer phase features (i.e. molecular weight, monomer chemistry) on the osteoinductivity, mechanical and degradation properties of composites (Chapters 4-7). Further, the importance of role of body fluid uptake by biomaterials is also hypothesized and studied using, besides composites, also calcium phosphate ceramics (Chapter 7). Finally, a general discussion and conclusion are reported in Chapter 8. 


\section{CHAPTER 2}

The role of gels in bone instructive putties

The results described in this Chapter are published in:

Barbieri D, Yuan H, de Groot F, Walsh WR, de Bruijn JD. Influence of different polymeric gels on the ectopic bone forming ability of an osteoinductive biphasic calcium phosphate ceramic. Acta Biomater. 2011, 7, 2007. 



\subsection{Introduction}

There is a worldwide increasing population with likely more bone injuries due to age and accidents. Consequently, the number of annual bone graft procedures is steadily growing and is leading to the search of improved grafting techniques.[258] Due to the many disadvantages of the gold standard autologous bone grafting (i.e. additional surgical procedure, pain and limited availability), there is a need for developing alternative (synthetic) bone graft materials that can stimulate bone healing. Commercially available bone growth factors such as rhBMP-2 have a strong osteoinductive potential but can result in undesired ectopic bone growth, ${ }^{[259]}$ and complications with its use in spinal surgery have been reported, ${ }^{[408]}$ making them suboptimal to replace autografts in the long term. Inorganic, synthetic materials such as polymers and calcium phosphate ceramics on the other hand, generally do not have bone-inducing potential and can therefore only be used to repair small bone defects in an osteoconductive fashion.

In the past two decades, calcium phosphate ceramics with micro-structured surface have been reported to have the unique ability to induce bone growth when intramuscularly implanted in large animals (e.g. dog, sheep and goat) without addition of (osteogenic) factors or cells.[217, 220, 225, 226, 236, 260-263] Although the process underlying bone induction by these materials has not yet been fully elucidated, surface micro- and nano-structural features such as grain and micro-pore size have been shown to play a crucial role. ${ }^{[86]}$ When micro-structured hydroxyapatite (HA) was implanted in the muscle of dogs, it induced ectopic bone formation. On the contrary, HA lacking such surface micro-structure was not able to trigger osteoinduction ${ }^{[236,237]}$ Similar results were shown in studies comparing $\mathrm{HA}$ and biphasic calcium phosphate (BCP) ceramics with various micro-porosity. ${ }^{[228]}$ It has furthermore been shown that micro-structured, osteoinductive calcium phosphate ceramics are superior to nonosteoinductive calcium phosphate ceramics for the repair of critical sized bone defects (e.g. $17 \mathrm{~mm}$ diameter in goats). ${ }^{[86,238]}$ Recently, it has even been shown that these materials are a promising synthetic alternative to autologous bone grafting.[86]

Since most calcium phosphate ceramics are prepared in block or particular form, their handling properties are not optimal. Placing individual particles in bone voids may lead to incomplete filling of irregularly shaped defect or granule dispersion and loss during surgery. To overcome these issues, calcium phosphate-based cements have been developed as alternatives ${ }^{[264-266]}$ but inherent drawbacks include unstable flowability, which is dependent on the setting time, ${ }^{[267]}$ lack of micro- and macroporosity to allow angiogenesis and tissue ingrowth, ${ }^{[268]}$ slow cement resorption ${ }^{[266]}$ and they are not osteoinductive.[269] These disadvantages might be surmounted by developing injectable pastes or putties where a binder or gel with proper rheological 
and cohesion characteristics is added to the calcium phosphate ceramic granules. ${ }^{244,}$ 270-274] This would allow mouldability of the material, i.e. it would be possible to shape and place it to fit a defect of irregular geometry guaranteeing direct contact with the bone surrounding the defect. Currently several commercial injectable or mouldable bone grafts are available, ${ }^{[275]}$ but so far none of them contain osteoinductive ceramics. Adding a polymer binder to osteoinductive calcium phosphate ceramic granules would appear the method of choice, but this may be detrimental to their osteoinductive potential. It has been suggested that the mechanism of material-directed osteoinduction involves the attachment of progenitor cells to the material surface followed by osteogenic differentiation and bone deposition, ${ }^{[86]}$ thus covering the micro-structured material surface with a polymer binder/gel may inhibit or delay osteoinduction. We hypothesise that, besides an inert chemistry, a rapid dissolution and clearance of the polymer binder surrounding micro-structured calcium phosphate granules are needed to let osteoinduction occur. To test this, we prepared putties with five different polymer gels and surface micro-structured biphasic calcium phosphate granules. The putties were evaluated in vitro as regards the gel dissolution rates, while the effect of the gels on the bone forming ability of the putties was ectopically evaluated using an intramuscular implantation model.

\subsection{Materials and methods}

\subsubsection{Polymer gels}

Five polymer gels, with a history in medical or pharmacological use, were prepared using raw polymer particles: (1) high viscosity carboxymethyl cellulose sodium salt (CMC, VWR, Lutterworth, United Kingdom), (2) Pluronic ${ }^{\circledR}$ F-127 (PLU, SigmaAldrich, Steinheim, Germany), (3) polyvinyl alcohol (PVA, Merck, Darmstadt, Germany), (4) native chitosan (CHI, Marinard Biotech, Rivière-au-Renard, Canada) and (5) native sodium alginate (ALG, Sigma-Aldrich). The technical details and clinical applications of the polymers are summarised in Table 1. Depending on the polymer used, different concentrations of polymer gels were prepared by combining raw polymer particles with aqueous solvents (Table 2). The final concentration of the gels was set according to the ability of the gel to retain calcium phosphate granules in putties (described in detail in §2.2.2). The solutions were stirred until complete dissolution and the $\mathrm{pH}$ of $\mathrm{CH}$ solution was adjusted to 7 at $37 \pm 2^{\circ} \mathrm{C}$ with using an aqueous solution of $48 \% \mathrm{w} / \mathrm{v}$. glycerol phosphate disodium salt (Sigma-Aldrich). At the same time, the $\mathrm{pH}$ of the other solutions was in the physiological range and there was no need to adjust it (Table 2). The gels were then placed in syringes (BD Plastipak $^{\mathrm{TM}}, 50 \mathrm{cc}, \mathrm{BD}$, Temse, Belgium), sealed with syringe caps and stored till use. Depending on the gel, the storage could be at room temperature for those prepared 
with synthetic raw polymer powders (i.e. PLU and PVA) or in refrigerator at $4^{\circ} \mathrm{C}$ to prevent possible mildew formation in the case of natural origin gels, i.e. CMC, ALG and $\mathrm{CHI}$ (Table 2).

\subsubsection{Preparation of putties}

Irregularly shaped granules of osteoinductive surface micro-structured biphasic calcium phosphate ceramic (BCP, particle size 1-2 mm, kindly supplied by Xpand Biotechnology BV, Bilthoven, the Netherlands) were used. The chemistry of the ceramic granules was analysed by X-ray diffraction (XRD, Rigaku MiniFlex I, Rigaku, Tokyo, Japan), while the surface morphology and the grain size were evaluated with scanning electron microscopy (SEM, Philips XL 30 ESEM-FEG, Philips, Eindhoven, the Netherlands). For each putty, one cc of ceramic particles was mixed with the respective gel to obtain a volume ratio gel/BCP as low as possible but high enough to guarantee the moldability of the resulting putties. Once the materials were ready, they were placed in plastic syringes (Braun Injekt ${ }^{\mathrm{TM}}, 2 \mathrm{cc}$, Braun Medical Ltd, Sheffield, United Kingdom) and sealed with syringe caps. The materials were then sterilized using $\gamma$-rays (average irradiation dose $\sim 25 \mathrm{kGy}$, IsoTron Nederland BV, Ede, the Netherlands) for further studies.

\subsubsection{Dissolution of the gels and disintegration of the putties}

The dissolution rate of the gels was based on the time it took for the putties to fully disintegrate. This was evaluated by placing $1 \mathrm{cc}$ of each material ( $n=3$ per material) in wells containing $8 \mathrm{~mL}$ of phosphate buffered saline (PBS, Sigma-Aldrich) at $37 \pm 1^{\circ} \mathrm{C}$.

Table 1. Details on the raw polymers used to prepare the gels.

\begin{tabular}{|c|c|}
\hline Polymer & Uses \\
\hline $\begin{array}{l}\text { CMC } \\
\text { [viscosity in } 1 \% \text { water at } 20^{\circ} \mathrm{C}: 1500-2500 \mathrm{mPa} \mathrm{s}^{-1} \text { ] }\end{array}$ & $\begin{array}{l}\text { Used in several fields, including the preparation } \\
\text { of putties and injectable pastes for tissue } \\
\text { engineering.[270, 276, 277] }\end{array}$ \\
\hline $\begin{array}{l}\text { PLU } \\
{\left[M_{w}=12,600, \text { molar ratio PEO-PPO-PEO 98:68:98] }\right.}\end{array}$ & $\begin{array}{l}\text { Used in pharmaceutical applications as drug } \\
\text { deliver material.[276,278] }\end{array}$ \\
\hline $\begin{array}{l}\text { PVA } \\
\text { [Merck, } M_{w}=22 \mathrm{kDa} \text {, degree of hydrolysis } \geq 98 \% \text { ] }\end{array}$ & $\begin{array}{l}\text { Excellent material for medical applications such } \\
\text { as long-term implants }{ }^{[276,279]} \text { and soft contact } \\
\text { lenses. }{ }^{[280]}\end{array}$ \\
\hline $\begin{array}{l}\mathrm{CHI} \\
\text { [degree of deacetylation: } 94 \% \text { ] }\end{array}$ & $\begin{array}{l}\text { Recently approved for clinical use as wound } \\
\text { bandage thanks to its biocompatibility and anti- } \\
\text { bacterial properties.[276, 281] }\end{array}$ \\
\hline $\begin{array}{l}\text { ALG } \\
\text { [native, low guluronic content, but the } \\
\text { guluronic/mannuronic ratio (i.e. G/M) was not } \\
\text { released by the supplier] }\end{array}$ & $\begin{array}{l}\text { Clinically used in dental (e.g. dental impression } \\
\text { material and denture fixative) and drug fields } \\
\text { (controlled release tablets and encapsulation), } \\
\text { but it has also been studied as attractive } \\
\text { material for bone tissue engineering. }{ }^{276,282,283]}\end{array}$ \\
\hline
\end{tabular}


The observations were done through visual inspection of the shape changes of the putties over time. At different time points (0,30 minutes, 1, 3, 6 hours, 1, 2, 4, 7 and 14 days) the samples were observed and pictures were taken. Then the change in the surface area occupied by the materials (in the well) over time was evaluated with Photoshop CS5 software (v12.0, Adobe Systems Benelux BV, Amsterdam, the Netherlands). Firstly, the surface area of each well was selected and the corresponding number of pixels was read as $W$. The materials in each well at the considered time point $t$ were pseudo-coloured and the pixels were read as $M_{t}$. The percentage (changing) surface area occupied by the material (in the well) over time was determined as

$\Delta \mathrm{A}=100-\left[100 \cdot\left(\mathrm{M}_{\mathrm{t}}-\mathrm{M}_{\mathrm{t}-1}\right) / \mathrm{W}\right]$

where $\mathrm{M}_{\mathrm{t}-1}$ is the area occupied by the sample in the previous time point than $\mathrm{t}$. The data were finally plotted on a graph $\Delta \mathrm{A}$ over time.

Table 2. Conditions in which gels and putties were prepared

\begin{tabular}{lllll|l}
\hline Gels & \multicolumn{5}{l}{ Putties } \\
\hline Polymer & Solvent & $\begin{array}{l}\text { Concentration } \\
{[\% \text { wt. }}\end{array}$ & $\begin{array}{l}\text { Temperature } \\
{\left[{ }^{\circ} \mathrm{C}\right]}\end{array}$ & $\mathrm{pH}$ & $\begin{array}{l}\text { Gel/BCP } \\
{[\% \text { volume ratio] }}\end{array}$ \\
\hline $\mathrm{CMC}$ & Water & 5 & $60 \pm 5$ & $7.3-7.8$ & 1 \\
\hline $\mathrm{PLU}$ & Water & 38 & $40 \pm 5$ & $6.8-7.5$ & 0.85 \\
\hline $\mathrm{PVA}$ & Water & 25 & $80 \pm 5$ & $7.2-7.6$ & 0.75 \\
\hline $\mathrm{CHI}$ & $1.2 \%$ acetic acid & 1.6 & $37 \pm 2$ & $6.9-7.1$ & 0.95 \\
\hline ALG & Water & 5.25 & $60 \pm 5$ & $7.1-7.8$ & 1 \\
\hline
\end{tabular}

\subsubsection{Intramuscular implantation (sheep model)}

To evaluate the osteoinductive potential of the putties, sterile controls (BCP particles, size 1-2 mm, $1 \mathrm{cc}, \mathrm{n}=10$ ) and putties (1 cc, $\mathrm{n}=10$ per material) were implanted in the dorsal muscles of sheep for 12 weeks. With the permission of the local animal care committee (Animal Care and Ethics Committee, University of New South Wales, Sydney, Australia; protocol \#P07037), surgery was performed on 10 sheep (female, 2-3 years old) under general anaesthesia (Isoflurane, Organon, now Merck, Whitehouse Station, USA; $2 \%$ in oxygen, oxygen flow rate of $4 \mathrm{~L} \mathrm{~min}^{-1}$ ) and sterile conditions. The muscles were exposed by longitudinal skin incisions and two lines of independent muscle pockets were created by blunt dissection (the distance between the pockets on the same line was about $2.5-3 \mathrm{~cm}$ to ensure insulation between the putties and avoid possible reciprocal side effects between implants). The head of the syringe containing the putty was cut with scissors and the implant was directly inserted in each muscle pocket. The pockets were sealed individually with nonresorbable suture material and the wound was then closed using silk sutures. To monitor the bone formation during time, calcein (Sigma, St. Louis, USA; $10 \mathrm{mg} \mathrm{kg}^{-1}$ 
body weight) and xylenol orange (Sigma; $100 \mathrm{mg} \mathrm{kg}^{-1}$ body weight) were intravenously injected 3 and 6 weeks after the implantation respectively. Twelve weeks after implantation the animals were sacrificed with a lethal injection of pentobarbital (Vetanarcol ${ }^{\circledR}$, Organon; $60 \mathrm{mg} \mathrm{kg}^{-1}$ ). The samples were then harvested with their surrounding tissues and fixed in cold phosphate buffered formalin solution for 72 hours for further processing.

\subsubsection{Histology and histomorphometry analysis}

After rinsing with phosphate buffer saline (PBS, Sigma-Aldrich), all the samples were trimmed from the surrounding soft tissues, dehydrated in a series of ethanol solutions $(70 \%, 80 \%, 90 \%, 95 \%$ and $100 \% \times 2$; Merck) and embedded in methyl metacrylate (MMA, LTI Nederland, the Netherlands). Non-decalcified histological sections (10-20 $\mu \mathrm{m}$ thick) were made using a diamond saw microtome (Leica SP1600, Leica Microsystems, Germany). Sections were stained with $1 \%$ methylene blue (SigmaAldrich) and $0.3 \%$ basic fuchsin (Sigma-Aldrich) solutions after etching with acidic ethanol (Merck), while unstained sections were prepared for fluorescent microscopy observations. The stained sections were scanned using a slide scanner (Dimage Scan Elite 5400II, Konica Minolta Photo Imaging Inc, Tokyo, Japan) to obtain overview images for histomorphometrical analysis. The sections were then observed with light microscope (Nikon Eclipse E200, Tokyo, Japan) to analyse the tissue response in detail, while unstained sections were observed with fluorescent microscopy (Nikon Eclipse E600, camera Nikon FDX-35) to determine the onset of bone formation. Histomorphometry was performed on the scanned images using Photoshop CS5 software (v12, Adobe Systems Benelux BV). Firstly the whole samples were selected as a region of interest and the number of pixels was read as $\mathrm{ROI}$. Then both the material and the mineralized bone were pseudo-coloured and their pixels were read as $M$ and $B$ respectively. The percentage of bone in the available space of the explants $\left(B_{p}\right)$ was determined as

$\mathrm{B}_{\mathrm{p}}=100 \cdot \mathrm{B} /(\mathrm{ROI}-\mathrm{M})$.

\subsubsection{Statistical analysis}

Average and standard deviations were calculated for the in vitro dissolution test, while a post-hoc Tamhane ANOVA test was used to evaluate the differences in bone formation between the control (BCP alone) and the putties. A p-value lower than 0.05 was considered as significant difference. Data elaboration and statistical analysis was performed using Origin software (v8.0773, OriginPro, Northampton, MA, USA). 


\subsection{Results}

2.3.1. Polymer gels and biphasic calcium phosphate ceramic

The composition of the polymer gels is illustrated in Table 1. As expected, chemical analysis with XRD confirmed that the BCP granules were composed of $80 \pm 5 \%$ of hydroxyapatite (HA) and $20 \pm 5 \%$ of $\beta$-tricalcium phosphate ( $\beta$-TCP) (Figure 1). SEM confirmed that the micro-structured surface was comprised of small grains (size $0.9 \pm 0.2 \mu \mathrm{m})$ and numerous micro-pores with size ranging between 0.55 and 1.06 $\mu \mathrm{m}$ (Figure 1).
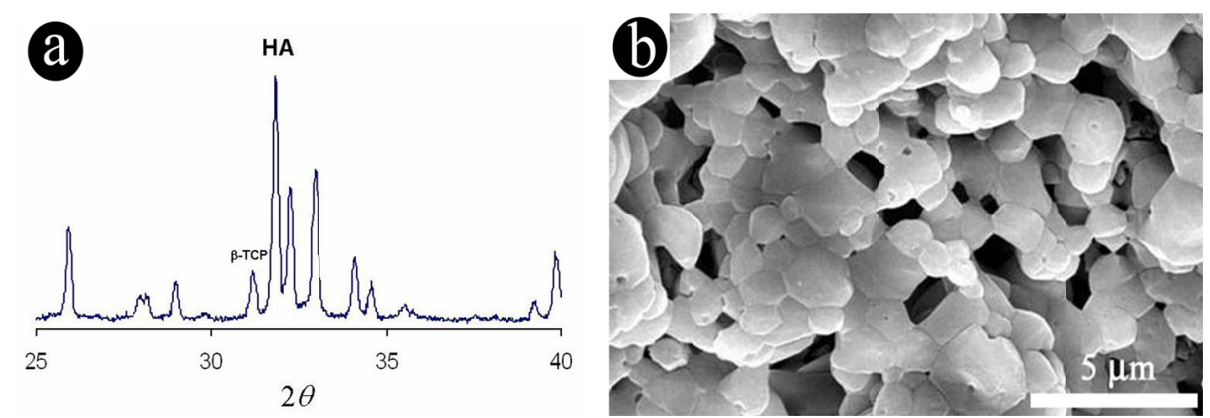

Figure 1. Characterization of $B C P$ granules. (a) XRD spectrum showing the two phases (HA and $\beta-T C P$ ) composing BCP. (b) SEM picture of the micro-structured surface of BCP granules.

After combining the polymer gels with BCP granules, the five putties appeared as soft and mouldable masses of ceramic granules stuck together. The gel between the particles was not visible except for alginate gel, which had brownish colour (Figure 2). As it may be observed, the putties had different gel/BCP volume ratios because of the different viscosities of the gels used (Table 2), which originated putties with very different handling properties. Using a stainless steel spoon at room temperature, the CMC-based putty was easy to handle without loss of particles, while those made of PLU, PVA and ALG gels were sticker and thus more difficult to shape. $\mathrm{CH}$ gel was not as viscous as the other four and the corresponding putties could lose some ceramic granules from the mass when shaped.

\subsubsection{Dissolution of the gels and disintegration of the putties}

Visual inspection and quantitative estimation of the gel dissolution rates showed that CMC, PLU and ALG-based putties lost their shape within 30 minutes and BCP granules were loose in one day, while $\mathrm{CHI}$ gel dissolved at a slower rate (Figure 2). In particular, ALG putty disintegrated quicker indicating ALG gel dissolved faster than CMC and PLU. On the contrary, PVA putty retained its shape over two weeks indicating slow dissolution rate of the gel. 


\subsubsection{In vivo tissue reaction of putties in sheep model}

A total of ten samples per material were intramuscularly implanted in ten sheep (Table 3). After three months, the samples were retrieved with their surrounding tissue and no inflammation was seen in any of the explants. However, it has been found in two sheep that two muscular pouches (containing one control and one putty respectively) were too close with each other and the implants could be not distinguishable anymore. Thus, four samples were lost (i.e. two controls, one $\mathrm{CHI}$ and one PVA putty). Bone formed in the controls and in all putties, except those based on PVA gel (Figure 3, Table 3).
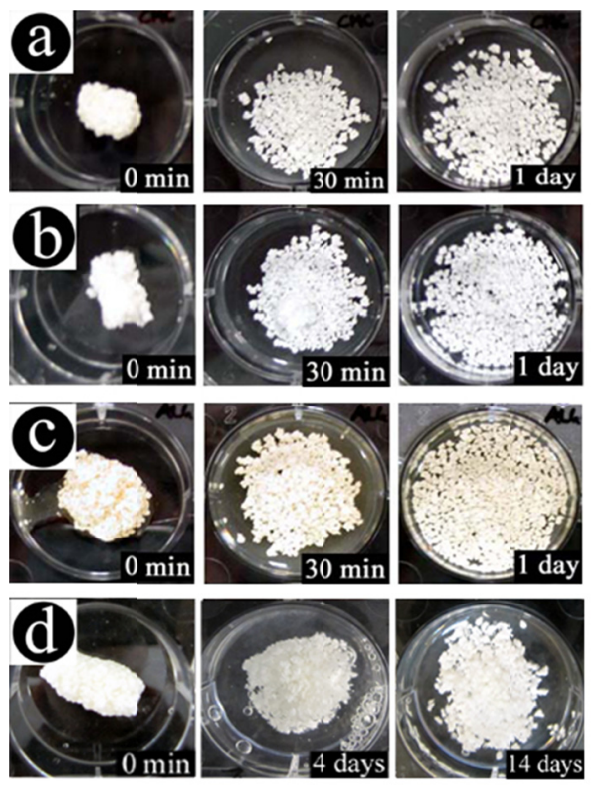
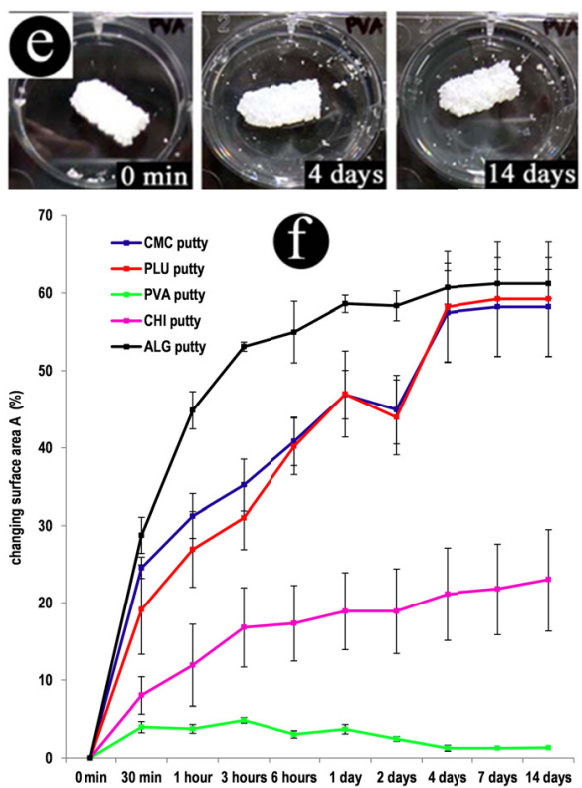

Figure 2. Dissolution test in PBS $\left(37^{\circ} \mathrm{C}\right)$ of the gels showing the disintegration of the putties, except for PVA-based one. (a) CMC putty. (b) PLU putty. (c) ALG putty. (d) CHI putty. (e) PVA putty. (f) Dissolution kinetics (i.e. $\triangle \mathrm{A} \%$ over time) of the gels in the putties over a 14-day period. Note that $C M C$, PLU and ALG-based putties have a significant higher dissolution rate as compared to $\mathrm{CHI}$ and PVAbased putties.

Table 3. Histomorphometry results after 12 weeks implantation in sheep. Statistical comparison is expressed in terms of $p$-values and is reported in the text.

\begin{tabular}{lll}
\hline Sample & Bone incidence & $\begin{array}{l}\text { Bone in available space } \\
{[\%]}\end{array}$ \\
\hline BCP granules $(1-2 \mathrm{~mm})$ & $8 / 8$ & $19.7 \pm 5.9$ \\
\hline CMC & $10 / 10$ & $18.9 \pm 10.4$ \\
\hline PLU & $10 / 10$ & $14.9 \pm 8.2$ \\
\hline PVA & $0 / 9$ & $0 \pm 0$ \\
\hline CHI & $6 / 9$ & $8.7 \pm 7.4$ \\
\hline ALG & $8 / 10$ & $9.6 \pm 9.9$ \\
\hline
\end{tabular}


When histomorphometrically compared to the controls, significantly less bone was formed in ALG and $\mathrm{CHI}$ putties ( $p=0.043$ and $p=0.041$ respectively), while bone formation in CMC and PLU-based putties was not significantly different from the controls ( $p=1$ and $p=0.938$ respectively) (Figure 4). After 12-week implantation, CMC, PLU and ALG gels were not histologically visible in the explants. On the contrary, traces of $\mathrm{CHI}$ gel were still present in the samples and PVA gel still occupied most of the space between BCP granules (Figure 5). When bone formed, it was found on the surface of the ceramic in both the controls and putties (Figure 5). Osteoblasts were seen on the outer surface of the newly formed bone indicating that after 12 weeks bone formation was still active (Figure 5). Once the gels did not occupy the available space between the granules, bone formed and well-developed blood vessel networks could be observed without any detectable difference amongst the putties (Figure 5). Under fluorescent microscopy, calcein (green, week 3 ) and xylenol orange (red, week 6) were detected in all the samples that induced bone formation. In particular, calcein was observed on BCP granules (in both controls and putties) while xylenol orange was seen on the newly formed bone (Figure 6), indicating that the process of bone formation started between 3 and 6 weeks after implantation.

\subsection{Discussion}

The possibility to develop osteoinductive mouldable materials has been assessed in this study. We used five potential polymer binders, chosen basing on their history of use in pharmaceutical and medical fields (Table 1). The ability of the gels to retain ceramic granules was studied first, and then their biocompatibility and effects on the osteoinductive potential of BCP granules have been evaluated with an animal study. The importance of surface micro-structure on osteoinduction of calcium phosphate ceramics has already been shown in several studies. $[86,228,236,237]$ The results herein presented show that once a polymer binder covers the surface of micro-structured BCP for a period longer than two weeks in vitro (i.e. PVA gel), osteoinduction does not occur. However, as we hypothesized, if the polymer binder can be quickly cleared by dissolution, osteoinduction of micro-structured BCP in putties may be guaranteed. We observed that the carrier component of the putties dissolved in vitro with different rates (Figure 2) loosening the BCP granules: CMC, PLU and ALG gels started to dissolve in short time (i.e. within few hours) and their putties completely lost their shape within one day, while putties containing $\mathrm{CHI}$ gel started to lose shape later and PVA putties kept their integrity up to 14 days. During histology analysis, we could not detect any trace of CMC, PLU and ALG gels in their harvested putties, while traces of $\mathrm{CHI}$ gel were occasionally observed. 

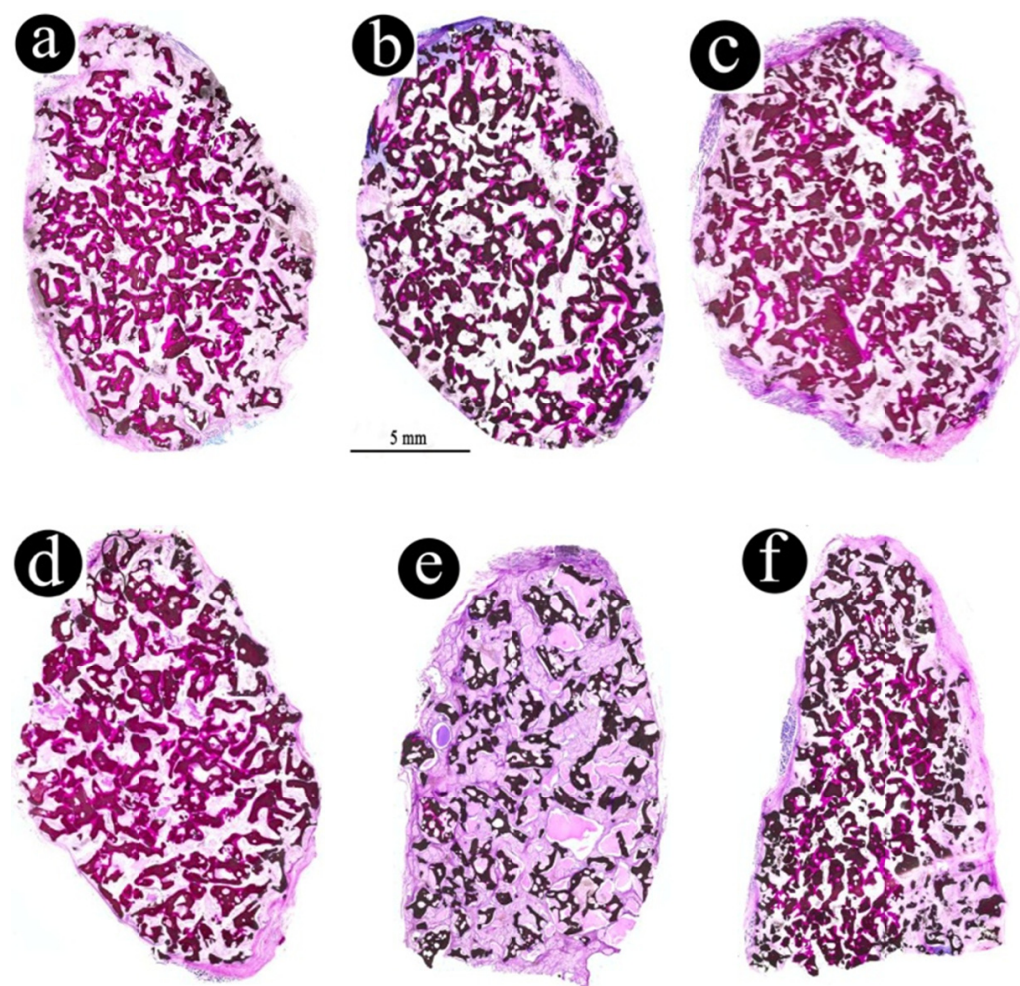

Figure 3. Histology overview of the explanted putties. Bone was observed in (a) CMC putty, (b) PLU putty, (c) ALG putty, (d) CHI putty and (f) BCP granules alone (i.e. control). No bone could be observed in (e) PVA putty, while remnant PVA gel was still visible amongst the granules. The histology staining is methylene blue/basic fuchsin where bone is dark pink/red, soft tissues are light violet/pink and BCP granules are dark brown/black. The gel in PVA putty (e) is stained light pink (for detail see Figure 5).

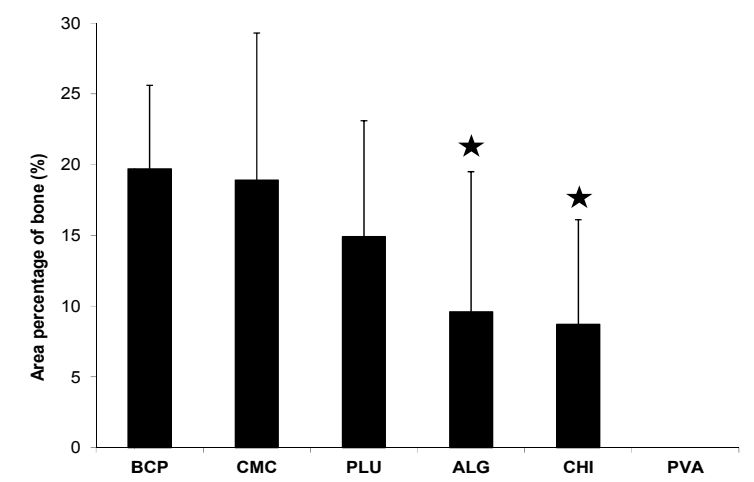

Figure 4. Histogram showing the area percentage of bone in the different groups after 12-week intramuscular implantation. As compared to the controls, significantly less bone was formed in ALG and $\mathrm{CHI}$ putties (indicated by stars), while the decrease of bone formation in CMC and PLU-based putties was not significant. Putties containing PVA gel did not induce bone formation. Statistical comparison is expressed in terms of $p$-values and is reported in the text. 
In the case of PVA-based putties, the gel was still present in all the explants. When comparing the in vitro and in vivo data, we could observe a possible relation between the in vitro dissolution and the in vivo clearance of the gels. It is noticeable that, as already reported in other studies, BCP granules are not expected to significantly degrade and/or resorbe in vivo over 12 weeks. ${ }^{[284]}$ However it can be hypothesized that, when putties were implanted in vivo, the gels started to dissolve, probably due to the attack of water that started their hydrolysis, and were cleared away by body fluids. During their clearance, the available space between the BCP granules may have increased over time allowing soft tissues, including blood vessels, to gradually enter into the implants. This was possibly followed by colonisation of the micro-structured BCP surface by (stem) cells which finally may have been instructed to osteogenically differentiate and trigger heterotopic bone formation (Figures 3,5). The lack of osteoinductive potential in PVA putty could be the result of preventing cells to reach the BCP surface. As already mentioned, after 12 weeks in vivo, the PVA gel was still completely present amongst BCP granules while no bone formed and cells were hardly seen in the implant. Meanwhile some residuals of $\mathrm{CHI}$ gel were observed and no traces of CMC and PLU gels were present. Bone and cells were abundant in CMC and PLU putties but they were less present in $\mathrm{CHI}$ putty. From these observations, a correlation between bone formation and gel dissolution (except ALG, as discussed here later) is likely. Although the dissolution rate and rapid clearance of the gels could be important factors controlling bone induction, other factors cannot be ruled out. For example, putties comprising the ALG gel, which had quicker dissolution rate than CMC and PLU gels, showed less bone formation. Thus, other factors must have influenced on osteoinduction, such as the chemistry of the gel or its degradation residuals. Alginate is a copolymer composed of guluronic $(G)$ and mannuronic $(M)$ acid blocks in different $\mathrm{G} / \mathrm{M}$ content ratios that have been shown to influence the biological properties of the gels. ${ }^{[285-287]}$ According to some studies, high content of $G$ residuals provokes severe inflammation, $\left.{ }^{285}, 286\right]$ while others suggested that it is caused by low $G$ content. ${ }^{[287]}$ We used native sodium alginate powder with low $G$ content and did not observe clear signs of inflammatory reaction to ALG putties. The lower osteoinductive potential of ALG putties may be related to the biological inertia of alginate. It has been shown that native alginate does not promote significant cell adhesion ${ }^{[288,289]}$ while CMC and PLU gels were reported to support the cells adhesion and bone formation in vitro and in vivo. ${ }^{[290,291]}$ Thus, not only the dissolvability but also the chemistry of the gel and its degradation products may play a role in decreasing the osteoinductivity of some putties. 

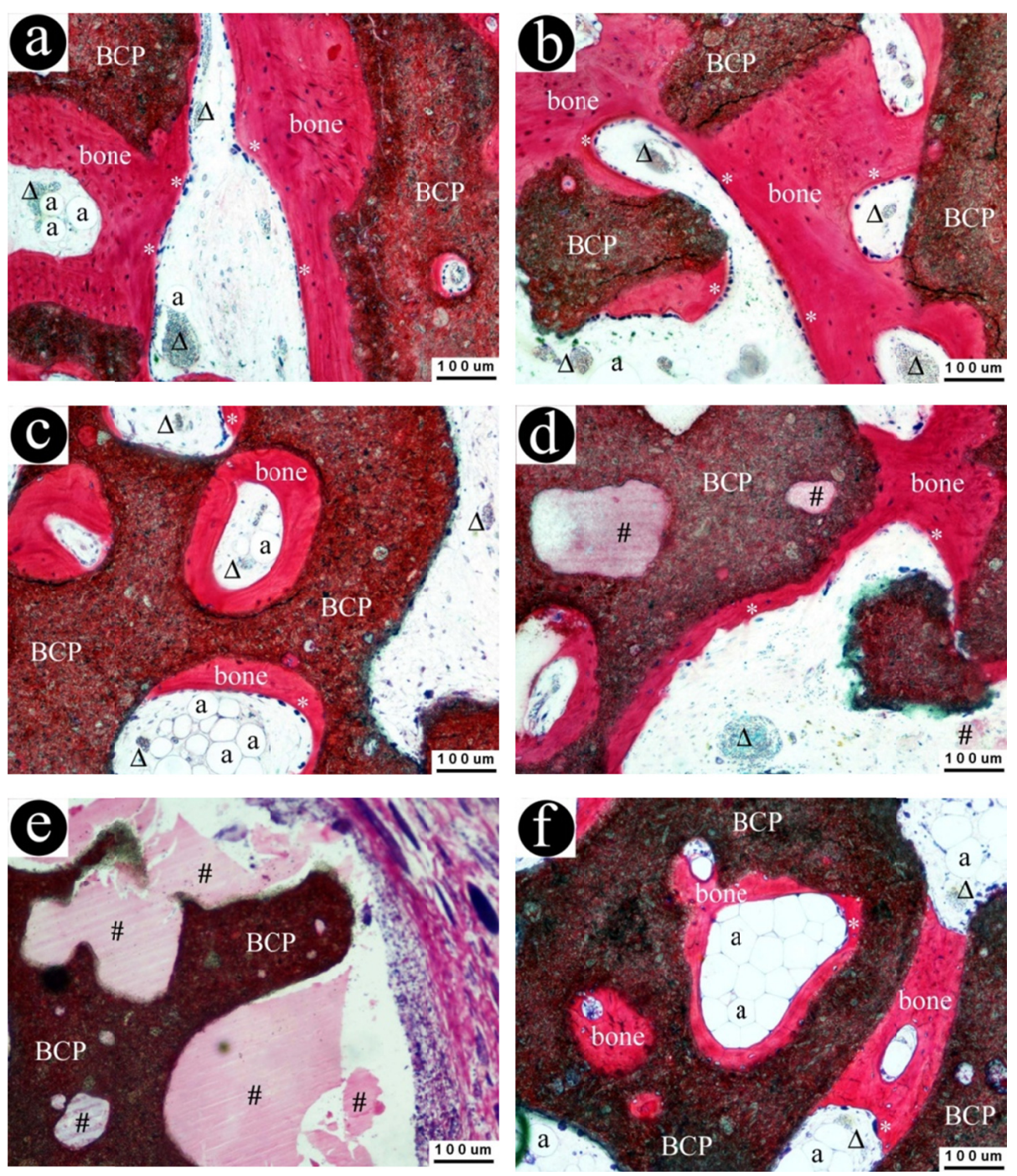

Figure 5. High magnification microscope observations of the explants after 12-week intramuscular implantation. (a) CMC putty. (b) PLU putty. (c) ALG putty. (d) CHI putty. (e) PVA putty. (f) BCP alone. Bone is formed in the materials where the gel has dissolved, i.e. CMC, PLU, CHI and ALG. Active osteoblastic cells on the outer bone surface are visible $\left({ }^{*}\right)$, while adipocytes (a) and blood vessels $(\Delta)$ can be seen in the available space between BCP particles in the explants. Note the traces of gel in the $\mathrm{CHI}$ and PVA putties (\#). The histology staining is methylene blue/basic fuchsin where bone is red, soft tissues are violet and BCP granules are dark brown/black. 

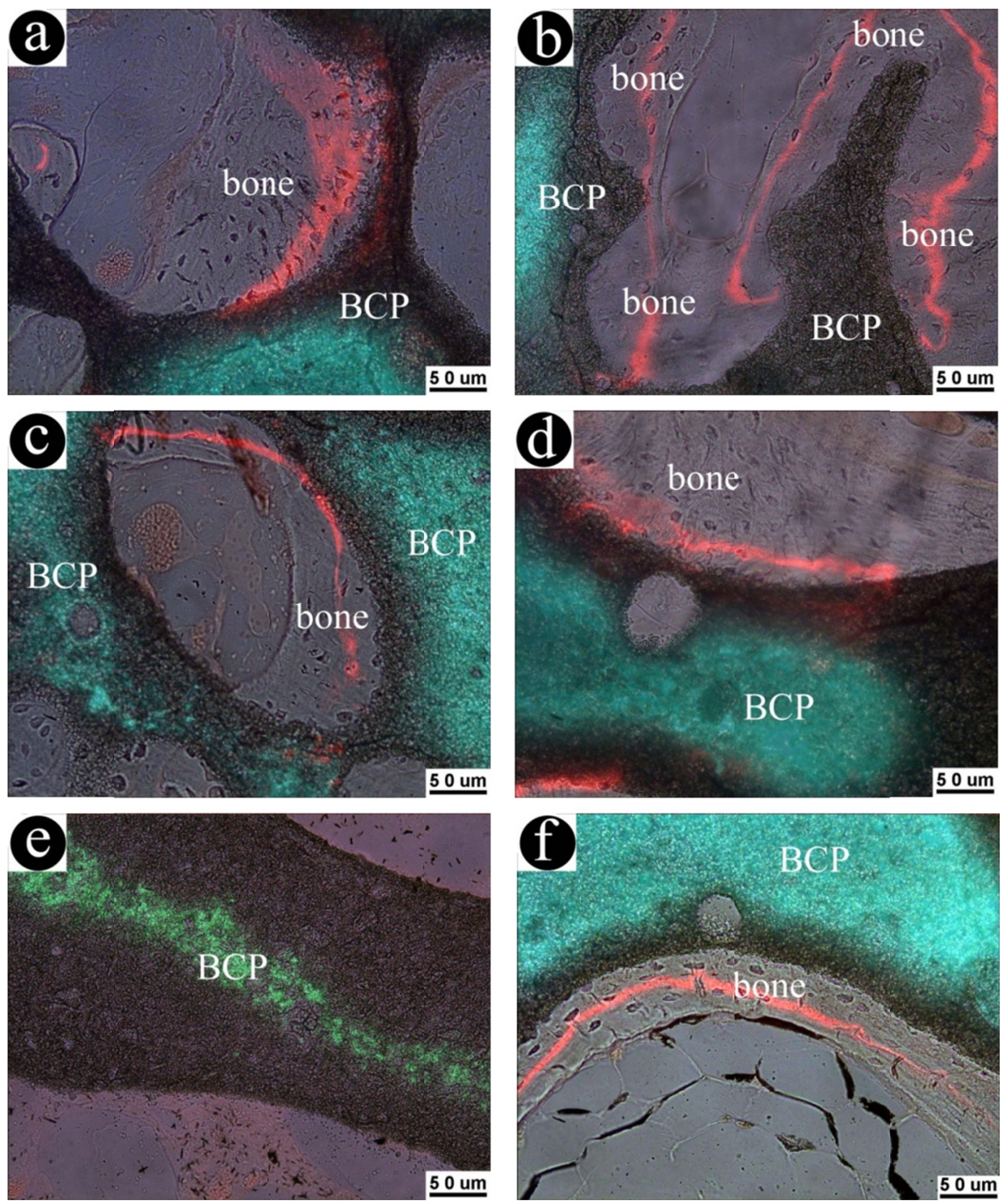

Figure 6. Microscopy images of the various groups obtained by overlapping the fluorescent and transmitted light images taken in the same position. Bone started to form in the control and putties between 3 and 6 weeks after the implantation (xylenol orange, red) except in PVA putties. (a) CMC putty. (b) PLU putty. (c) ALG putty. (d) CHI putty. (e) PVA putty. (f) BCP alone.

In conclusion, the factors that may influence ectopic bone formation in putties are (i) the filling of the available space with the gels because it delays or even prevents the soft tissue infiltration and angiogenesis, slowing down or stopping the migration of (stem) cells into the implant where they could contact the micro-structured BCP surface and (ii) the chemistry of the gels or their degradation products since they 
may inhibit or slow down the (stem) cell adhesion, proliferation and osteogenic differentiation onto BCP granules. Although several polymer gels inhibit or limit bone formation in the putties, we have shown that certain biocompatible gels with fast dissolution rate (i.e. CMC and PLU gels) allow inductive bone formation in similar volume as the control (i.e. loose BCP granules). These results show that it is possible to develop osteoinductive putties for bone repair. However, it should be observed that five gels with various chemistries and putties having different gel/BCP volume ratios have been used in this study. Therefore, to ensure that the gel dissolution rate is the key factor controlling bone induction in these composite materials, future experiments should focus on one gel chemistry with varying dissolution rates. It would be useful to implant the materials in orthotopic sites to evaluate their clinical potential. Further, analysing the temporal evolution of bone formation, both in heterotopic and orthotopic sites, by using multiple time points during the animal studies would provide useful information to better understand the biology of bone formation induced by such biomaterials and the role played by the gel component.

Further, it should be mentioned that the carriers used in this study, similarly to others reported in literature, ${ }^{202,293]}$ were water-based. The prolonged contact of calcium phosphate ceramics, including those slowly dissolvable, with such aqueous gels will eventually lead to their hydrolysis changing their surface topographical structure and chemistry. [222, 294] Since water-based gels contain high content of water (i.e. 60 to $95 \%$ wt., Table 2) we recently performed an accelerated aging test based on the approach (derived from Arrhenius relation) assuming that the rate of aging is increased by a factor ${ }^{[368]}$

$f=2^{(T-T \text { ref }) / 10}$

where $T_{\text {ref }}$ is the temperature at which the effects of aging are to be determined and $T$ is an elevated temperature used to accelerate these effects. ${ }^{[353,368]}$ The factor $f$ indicates how many months at $T_{\text {ref }}$ are equivalent to aging the material at $T$ for one month. The condition to apply this factor is that the (accelerated) aging temperature $T$ should be (sufficiently) lower than the temperature at which the tested material distorts. ${ }^{[368]}$ In general, such temperature T should be 5 to $10^{\circ} \mathrm{C}$ less than any major thermal transition. ${ }^{[368]}$ For example, in the case of medical devices comprising polymers it is suggested that $\mathrm{T}$ should be not higher than $60^{\circ} \mathrm{C}$ as above it non-linear changes would occur in many polymer systems.[353-357, 368] Calcium phosphate ceramics are thermally instable for temperatures higher than $850^{\circ} \mathrm{C},[369-370]$ thus we could apply the above equation with $\mathrm{T}_{\text {ref }}=20^{\circ} \mathrm{C}$ and $\mathrm{T}=50^{\circ} \mathrm{C}$. In this way, keeping the granules at $50^{\circ} \mathrm{C}$ for one month corresponds to aging them at $20^{\circ} \mathrm{C}$ for 8 months. So, 
to simulate the aging of osteoinductive ceramics at $20^{\circ} \mathrm{C}$ for approximately two and four years, we immersed micro-structured tricalcium phosphate ceramic granules in pure deionized water at $50^{\circ} \mathrm{C}$ for 104 and 208 days respectively. Quadrilateral shaped grains were formed (Figure 7), while the chemistry remained unaltered.[295] Given the critical importance of surface micro-features in determining the bone forming potential of ceramics, ${ }^{[86]}$ we believe that the observed surface grains reorganization at the TCP surface will negatively affect their osteoinductive potential.
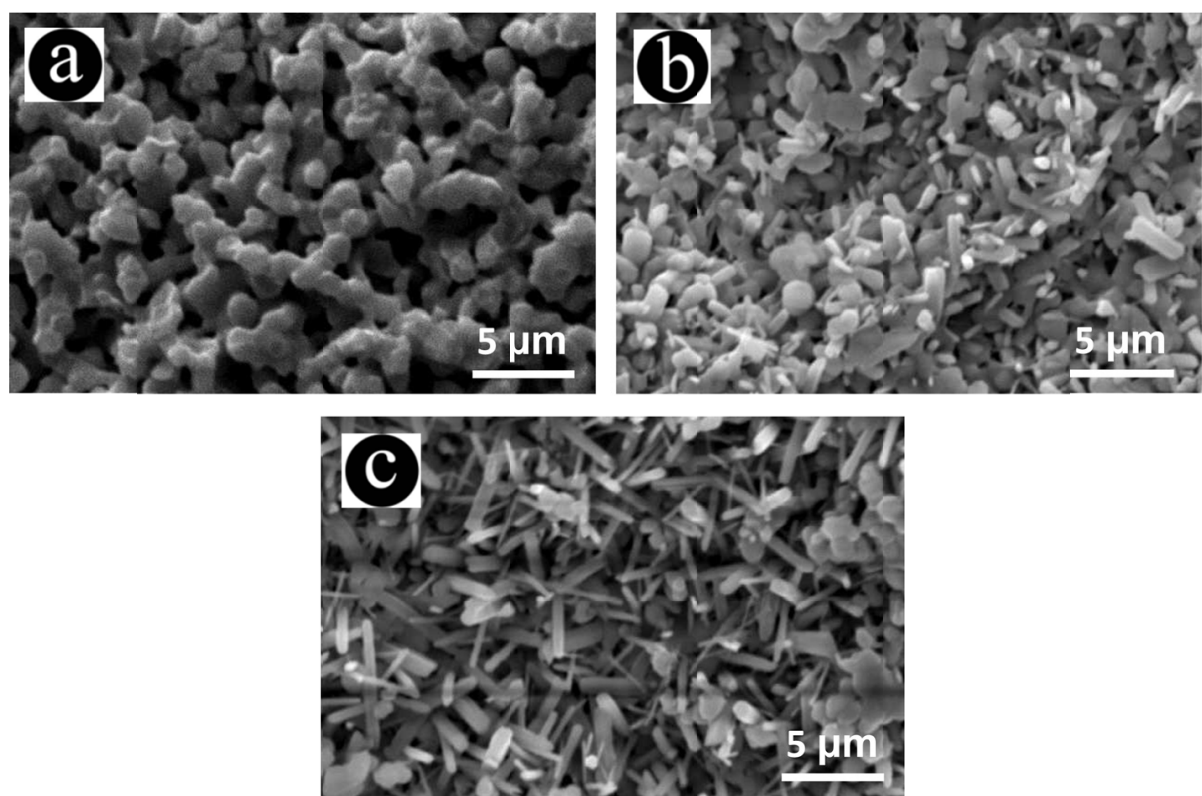

Figure 7. Scanning electron microscopy images of loose tricalcium phosphate granules during accelerated ageing experiment in pure deionized water. (a) Starting surface with the characteristic micro-structure. (b) After 104 days in aqueous environment at $50^{\circ} \mathrm{C}$ (i.e. simulation of 2 years at $20^{\circ} \mathrm{C}$ ) the surface starts to present some quadrilateral grains. (c) After 208 days in water at $50^{\circ} \mathrm{C}$ (i.e. simulation of 4 years at $20^{\circ} \mathrm{C}$ ) there are plenty of acicular shaped grains. All images were kindly provided by Davison N (Xpand Biotechnology BV, Bilthoven, the Netherlands).

On these bases, various formulations of water-free gels using glycerol as solvent instead of water have been proposed by members of our group. ${ }^{[295]}$ These carriers were then used in combination with TCP granules having different size, i.e. $0.5-1 \mathrm{~mm}$ and $150-500 \mu \mathrm{m}$ to obtain putties and injectable pastes respectively. Such materials were then aged at $50^{\circ} \mathrm{C}$ for 104 and 208 days, and the lack of water in the carriers (i.e. its content was measured as low as $10 \% \mathrm{v} / \mathrm{v}$.) preserved the ceramic grain size and shape together with its porosity and chemistry. ${ }^{[25]}$ The dissolution kinetics of these putties and pastes was evaluated in vitro in phosphate buffered saline at 
physiological temperature. They were also intramuscularly implanted in femoral defects and paraspinal muscles of dogs to evaluate their osteoconductive and osteoinductive potentials respectively. The results showed that, in general, fast dissolvable gels (i.e. dissolution time shorter than 48 hours) do not hinder heterotopic bone formation by putties and pastes, ${ }^{[295]}$ confirming the hypothesis proposed earlier in this chapter. However, we observed that carriers dissolving too quickly (i.e. less than 8 hours) did not allow the formation of blood clots around the implant, which can hold the ceramic particles in place. ${ }^{[25]}$ Conversely, the ceramic granules incorporated in too slowly dissolvable carriers (i.e. dissolution time longer than 48 hours) were surrounded by fibrous tissue that likely obstructed bone formation in both muscle and bone defects. ${ }^{[25]}$ The in vivo performance of the studied putties and pastes in orthotopic and heterotopic sites seemed to be linked: those formulations that could ectopically induce more bone also could bridge bone in femora defects more efficiently.[295] These results confirm previous work which suggested that, in the repair of bone defects, an osteoinductive material will tend to perform better than its nonosteoinductive counterparts. ${ }^{[86,238,296]}$ The results presented herein indicate that the availability of the ceramic micro-structured surface to the surrounding tissue shortly after implantation (i.e. $24-48$ hours) is of primary importance for osteoinduction. Besides this, free space between granules is likely necessary for vasculature formation, which may be obstructed with slower degrading carrier formulations.

\subsection{Conclusion}

We have shown that when creating moldable putties the osteoinductivity of microstructured biphasic calcium phosphate granules can be affected by the addition of polymer gels. We observed that putties prepared with fast dissolving gels, which are rapidly cleared, generally allow ectopic bone formation, even though the chemistry of the polymer binder may also have an effect on bone formation. Further studies are necessary to better assess the effects of the gel dissolution rate and chemistry on the osteoinduction of putties. 


\section{ADDENDUM}

\section{2a.1. Introduction}

As mentioned in §2.1., improved handling properties of bone graft substitutes (e.g. cohesive moldability or injectability) are desired to fill morphologically complex defects such as those encountered during mandibular alveolar ridge reconstruction [297] or spine fusion procedures. ${ }^{[298]}$ Reducing the granule size of the ceramic phase added to polymer carriers may lead to paste-like materials that might be more easily placed and shaped in the defect sites. Such pastes may be delivered to the site by injection from a syringe and modelled to fit the defect. Thus, in this study we evaluated the osteoinductive potential of pastes comprising the most promising gels (amongst those studied in Chapter 2, i.e. CMC and PLU) and osteoinductive small granule size calcium phosphate ceramic. By virtue of the results described in Chapter 2, we expected that such pastes would be as osteoinductive as the loose ceramic granules.

\section{2a.2. Materials and methods}

\section{2a.2.1. Preparation of injectable pastes}

In this study we used small granules of osteoinductive biphasic calcium phosphate ceramic (BCP, particle size 212-300 $\mu \mathrm{m}$, Xpand Biotechnology BV). CMC and PLU gels were prepared as described in \$2.2.1. and pastes were made following the procedure described in §2.2.2. Briefly, the gel and BCP granules were mixed to obtain a gel/BCP volume ratio as low as possible but high enough to guarantee good flowability (i.e. the paste should flush out from the syringe with no effort and keep the shape). Once the materials were ready, they were placed in $2 \mathrm{cc}$ plastic syringes (Braun Medical Ltd) and sealed with caps. The materials were then sterilized using $\gamma-$ rays (average irradiation dose $\sim 25 \mathrm{kGy}$, IsoTron Nederland BV) for further studies.

\section{2a.2.2. Animal study (dog model)}

With the permission of the local animal care committee (Animal Center, Sichuan University, Chengdu, China; protocol \#P07047), BCP granules (1 cc, size 212-300 $\mu \mathrm{m})$ and injectable pastes based on CMC and PLU gels (1 cc) were implanted in the paraspinal muscles of eight skeletally mature mongrel dogs (male, 1-4 years old, weight $10-15 \mathrm{~kg}$ ) for 12 weeks to evaluate their osteoinductive property. The surgical procedure was performed under general anaesthesia (pentobarbital sodium, Organon; $30 \mathrm{mg} \mathrm{kg}^{-1}$ body weight) and sterile conditions. The back of the dogs was shaved and the skin cleaned with iodine. A longitudinal incision was made and the paraspinal muscle was exposed by blunt separation. Longitudinal muscle incisions were subsequently made with a scalpel and four separate muscle pouches were 
created by blunt separation (two pouches per side). The controls/pastes were placed/injected in the pouches and the wound was then closed in layers with silk sutures. After surgery, the animals received intramuscular injections of penicillin for three consecutive days to prevent infection. Twelve weeks after implantation, the animals were sacrificed and all the samples (except one PLU) were harvested with the surrounding tissues and fixed in $4 \%$ formaldehyde (Merck) solution $(\mathrm{pH}=7.4)$ at $4^{\circ} \mathrm{C}$ for one week.

2a.2.3. Histology and histomorphometry (dog model)

The qualitative and quantitative procedures are described in \$2.2.5. (except fluorescent imaging).

\section{2a.2.4. Statistical analysis}

Statistics was performed according using the tests described in §2.2.7.

\section{2a.3. Results and discussion}

Table 4 summarizes the final composition (gel/BCP volume ratio) of the materials. As it may be observed, such ratios are not the same because of the different viscosity of the two gels. It is interesting to observe that, as compared to the putties comprising the same gels (\$2.2.1.), the gel content in injectable pastes was larger to guarantee flowability in the syringe. After 12-week implantation, we did not observe inflammation signs in any explant whereas bone formed, with different incidence, in all the samples. When compared to the controls, bone formation in CMC and PLUbased injectable pastes was not significantly different from the controls $(p>0.2$ and $p>0.65$ for CMC and PLU respectively) (Table 5, Figure 8). The gels were not histologically visible in the explants and bone formed tight onto the surface of the ceramic in all materials (Figure 9). Osteoblasts were seen on the outer surface of the newly formed bone indicating that after 12 weeks bone formation was still active (Figure 9). Where bone formed, blood vessels were observed without any detectable difference amongst the pastes once the gels did not occupy the available space between the particles (Figure 9). The results herein presented demonstrate that fast dissolvable gels (i.e. CMC and PLU) can be used to manufacture osteoinductive pastes with small calcium phosphate ceramic granules (e.g. particle size smaller than $300 \mu \mathrm{m}$ ), which might be easily shaped or injected in the defect site. 
Table 4. Details on the preparation of injectable pastes.

\begin{tabular}{ll}
\hline Putty & $\begin{array}{l}\text { Gel/BCP } \\
{[\% \text { volume ratio] }}\end{array}$ \\
\hline CMC & 2 \\
\hline PLU & 1 \\
\hline
\end{tabular}

Table 5. Histmorphometry results in dog model. Statistical comparison is expressed in terms of $p$-values and is reported in the text.

\begin{tabular}{lll}
\hline Sample & Bone incidence & $\begin{array}{l}\text { Bone in available space } \\
{[\%]}\end{array}$ \\
\hline $\begin{array}{l}\text { Controls }(212-300 \mu \mathrm{m}) \\
\text { (i.e. BCP granules alone) }\end{array}$ & $8 / 8$ & $21.7 \pm 15.5$ \\
\hline CMC & $7 / 8$ & $14.0 \pm 11.2$ \\
\hline PLU & $5 / 7$ & $18.8 \pm 17.3$ \\
\hline
\end{tabular}

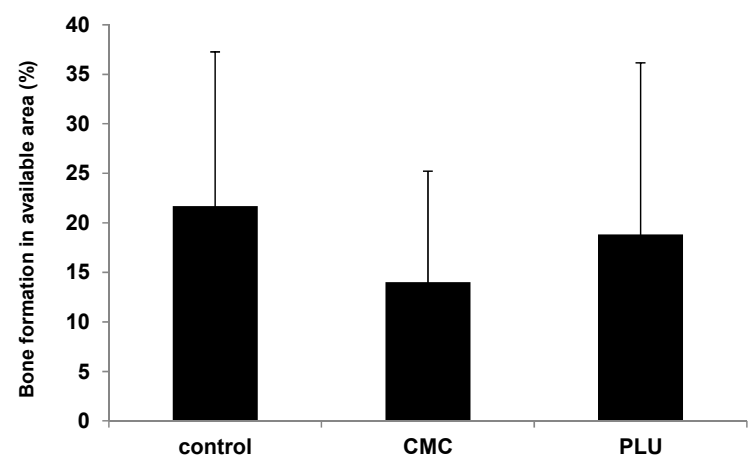

Figure 8. Histogram showing the area percentage of bone (calculated on the available space in the explants). As compared to the controls, the decrease of bone formation in CMC and PLU-based pastes was not significant. Statistical comparison is expressed in terms of p-values and is reported in the text.

\section{2a.4. Conclusion}

In this Addendum we have shown that instructive injectable pastes comprising small granule size of osteoinductive calcium phosphate ceramic are feasible. Further, the results presented here confirm the conclusion drawn in Chapter 2: fast dissolvable polymer binders allow osteoinduction of their putties and injectable pastes. 

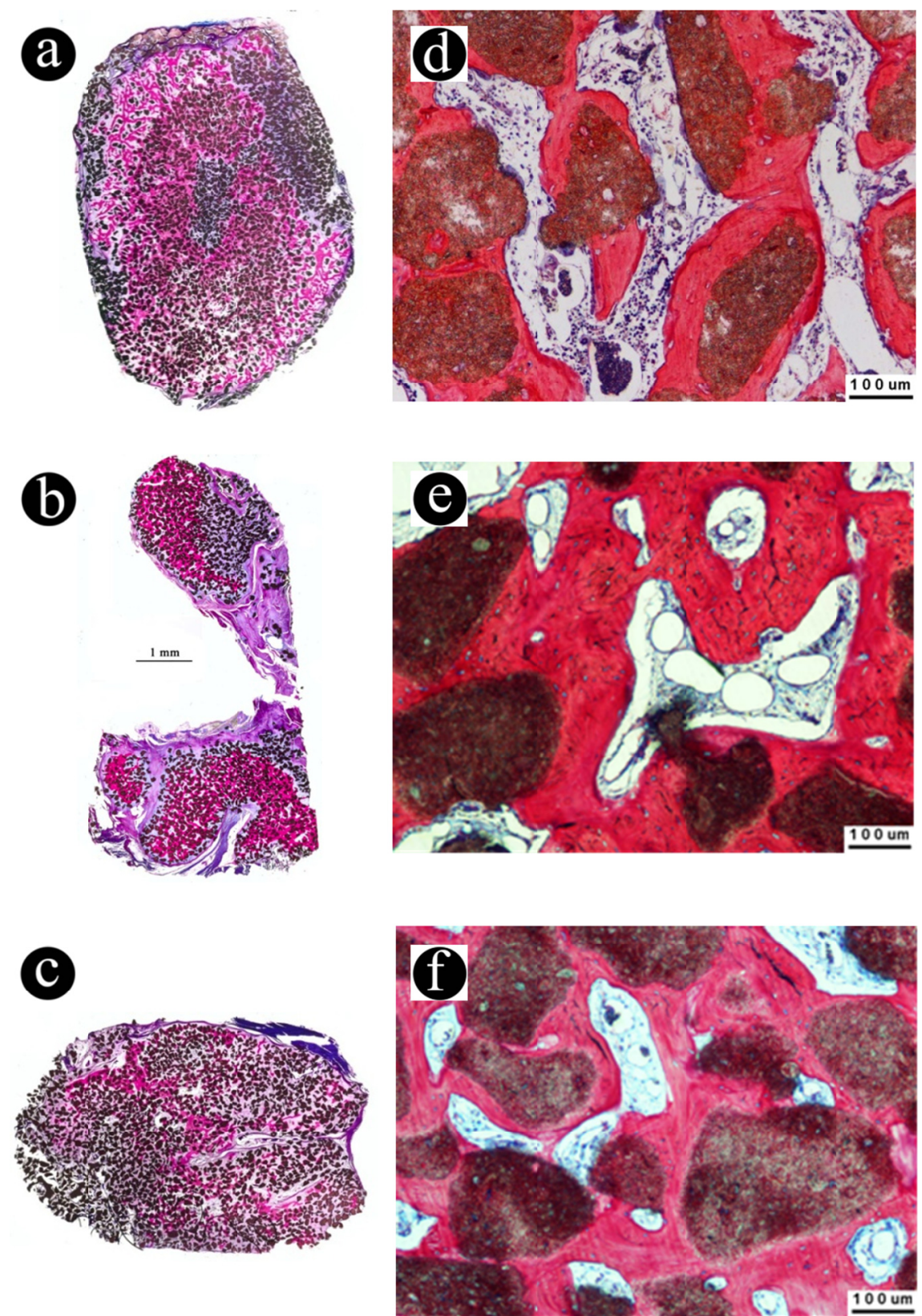

Figure 9. Histology overview of the explanted. (a) Control (i.e. BCP granules 212-300 $\mu \mathrm{m}$ ), (b) CMC and (c) PLU pastes. Bone induction is seen within all the materials. High magnification microscopy observations of the explanted (d) BCP granules, (e) CMC and (f) PLU pastes. Adipocytes (i.e. large white circles) and blood vessels (i.e. small circles with cells in) are present. Brown colour indicates BCP granules. Bone is stained red while interstitial matrix is blue/white. The samples were stained with methylene blue and basic fuchsin: bone is red, soft tissues are violet/light blue and BCP granules are dark brown/black. 
. 


\title{
CHAPTER 3
}

\author{
Instructive composites: \\ effect of filler content \\ on osteoinduction
}

The results described in this Chapter are published in:

Barbieri D, Renard AJS, de Bruijn JD, Yuan H. Heterotopic bone formation by nano-apatite containing poly(D,L-lactide) composites. Eur. Cell Mater. 2010, 19, 252. 



\subsection{Introduction}

Current methods to treat lost or damaged bone include the use of autografts and (processed) allografts. The former are considered the gold standard for bone repair but may lead to donor-site morbidity and have limited availability. Allografts do not have these complications but present risks of disease transfer, immunogenicity and reduced osteoinduction. ${ }^{[151]}$ An alternative to these natural bone grafts is the use of synthetic materials that ideally should be non-toxic, resorbable, osteoconductive, osteoinductive and have mechanical properties to suit their clinical application. In particular, osteoinduction is described as an instructive process where (immature) cells are driven to differentiate into osteogenic lines. Various stimuli are proposed to have a role in instructing cellular differentiation, such as the stiffness and topography ${ }^{[175-179]}$ of the tissue interstitial matrix or the physical contact with other cells present in the tissue. ${ }^{[180]}$ It has been demonstrated in vitro that specific characteristics of biomaterials, for example the surface stiffness or topographical features (e.g. tips or grooves), ${ }^{1185-188,191-197]}$ allow the control of stem cell fate. Osteoinduction, or improvements in the potential to support bone formation, can be introduced in materials by the addition of osteogenic cells or growth factors such as rhBMP-2. ${ }^{299-302]}$ However some materials have been reported to have 'intrinsic' osteoinductive properties by virtue of their physicochemical characteristics (i.e. such materials do not contain any cell or growth factor at the moment of implantation). Material-related osteoinduction in vivo has been widely demonstrated by implanting materials at ectopic sites (e.g. under the skin or in muscle), where they have no contact with osteoblasts and the resulting bone formation is only due to the recruitment and differentiation of circulating (progenitor) cells. So far, various materials have been reported to be osteoinductive, mainly calcium phosphate ceramics ${ }^{[217,220,222,225-228,237,262,303]}$ but also polyHEMA, ${ }^{[221]}$ surface treated titanium, ${ }^{[234]}$ and composites of polyester and hydroxyapatite. ${ }^{[235]}$ With the ceramics, evidence has been provided showing that the physico-chemistry and surface micro-structure play a role in the bone inductive potential of these materials. ${ }^{[86,}{ }^{228]}$ Examples of such osteoinductive calcium phosphate ceramics are hydroxyapatite $(\mathrm{HA})$, biphasic calcium phosphate (BCP) and tricalcium phosphate (TCP). It has also been demonstrated that osteoinductive calcium phosphate ceramics can provide fast bone repair and allow effective healing of critical-sized bone defects. ${ }^{[238,304]}$ However, the brittleness of these materials still limits their application in load-bearing sites, which drives research towards developing mechanically stronger materials such as composites. Polymers (e.g., polyesters, polyphosphazenes, polyanhydrides and polyorthoesters) have been used as implants for many medical applications. [261, 305] Amongst the synthetic biodegradable polyesters, polylactic acid is biocompatible and resorbs within few 
years into non-toxic components that can be cleared from the body. Polylactide is widely used in the medical field (e.g. screws, sutures) and as scaffold for tissue engineering and drug delivery applications. It has adequate mechanical properties for certain applications (e.g. screws and plates), but it is too elastic for load-bearing bone replacement purposes. ${ }^{[305]}$ Thus, introducing calcium phosphates into polylactide was an attempt to have osteoconductive materials with suitable mechanical properties. It has been shown that adding nano-hydroxyapatite particulate or fibres into polylactide materials improves the mechanical properties of the material, ${ }^{[239,}{ }^{240]}$ while composites containing more than $40 \%$ wt. hydroxyapatite renders the material osteoconductive.[241] Further, the presence of hydroxyapatite particles increased protein adsorption and enhanced osteoblast adhesion.[241-243] So far, only one composite of polyester and ceramic has been reported to be osteoinductive ${ }^{[235]}$ and, to our best knowledge, no literature about the effects of ceramic filler content on composite-related osteoinduction is available. In the current study we present an approach to produce instructive composites by introducing different amounts of nano-sized apatite into poly(D,L-lactic acid). We evaluated the materials both in vitro and in vivo regarding their chemistry, ion release rate, surface mineralisation and osteoinductivity and hypothesize that adding increasing amounts of nano-apatite to a polymer will generate a specific surface micro-structure that will result in an osteoinductive composite. More apatite particles exposed at the surface will allow higher ion release, protein adsorption and surface mineralization that should further enhance the bone regenerative properties. $\left.{ }^{86,}, 228,237,263\right]$

\subsection{Materials and methods}

3.2.1. Nano-apatite synthesis and physico-chemical characterization

Nano-apatite was prepared using a wet-precipitation reaction ${ }^{[306]}$ where $\left(\mathrm{NH}_{4}\right)_{2} \mathrm{HPO}_{4}$ (Fluka, Steinheim, Germany) aqueous solution ( $\mathrm{c}=63.1 \mathrm{~g} \mathrm{~L}^{-1}$ ) was added to $\mathrm{Ca}\left(\mathrm{NO}_{3}\right)_{2} \cdot 4 \mathrm{H}_{2} \mathrm{O}$ (Fluka) aqueous solution ( $\mathrm{c}=117.5 \mathrm{~g} \mathrm{~L}^{-1}$ ) with controlled speed (12.5 $\mathrm{mL} \mathrm{min}{ }^{-1}$ ) at $80 \pm 5^{\circ} \mathrm{C}$. The reaction $\mathrm{pH}$ was kept above 10 by using ammonia (Fluka) as buffer. After precipitation, the resulting apatite powder was aged overnight, washed with distilled water to fully remove ammonia and finally suspended in acetone (Fluka) at a concentration of $0.1 \mathrm{~g} \mathrm{~mL}^{-1}$. A small amount of the powder was then sintered at $1100^{\circ} \mathrm{C}$ for 200 min (Nabertherm C19, Nabertherm, Lilienthal, Germany) for chemical characterization. Both the unsintered and sintered apatite powders were analysed by Fourier transform infrared spectrometer (FTIR, Perkin Elmer Spectrum 1000, Perkin Elmer, Waltham, MA, USA) and X-ray diffractometer (XRD, Rigaku MiniFlex I, Rigaku, Tokyo, Japan). FTIR was run according a typical $\mathrm{KBr}$ pellet protocol and spectra were collected in the range $400-4000 \mathrm{~cm}^{-1}$ and analysed with 
the software OriginPro (v8.0773, OriginLab Corporation, Northampton, MA, USA) without any pattern elaboration. XRD was performed using $\mathrm{Cu} \mathrm{K}$ radiation $(\lambda=1.54056$ $\AA$ ) operating at $30 \mathrm{kV}$ and $15 \mathrm{~mA}$, and spectra were collected at $0.083 \mathrm{deg} \mathrm{sec}^{-1}$ in the 29 range $5-90$ deg and later analysed with the software Jade (v6.5.26, Materials Data Inc., Livermore, CA, USA). The particle size and morphology of the non-sintered apatite were characterized with high resolution scanning electron microscopy (HRSEM, Zeiss 1550, Carl Zeiss GmbH, Oberkochen, Germany) in the secondary electron mode and with transmission electron microscopy (TEM, Tecnai-200FEG, FEI Europe, Eindhoven, the Netherlands). The latter was equipped with an energy dispersive X-ray spectroscopy (EDX), which allowed estimating the calcium and phosphate contents in the unsintered sample.

\subsubsection{Nano-apatite structural characterization}

It is well-known that hydroxyapatite has a hexagonal lattice system $P 63 / m,{ }^{307]}$ thus the unit cell parameters $a$ and $c$ for the unsintered form of hydroxyapatite could be estimated by using XRD information on the measured $\vartheta$ and the corresponding $(h \mathrm{k} l)$ indices using the relationships (1) and (2), where (2) is referred to a hexagonal lattice: $[308,309]$

$\mathrm{d}=\mathrm{n} \cdot \lambda / 2 \cdot \sin \vartheta$

$1 / \mathrm{d}=\operatorname{sqrt}\left[\left[4 \cdot\left(h^{2}+k^{2}+h k\right) / 3 \cdot \mathrm{a}^{2}\right]+\left[{ }^{2} / \mathrm{c}^{2}\right]\right]$

with $\lambda$ the wavelength of the $X$-ray used in the analysis, $n$ is an integer representing the order of the diffraction peak (in this case, it is $n=1$ ), $d$ is the distance between two diffraction planes ( $d$-value) estimated from the corresponding measured diffraction angle $\vartheta$ and $(h k l)$ are the Miller indices for the chosen diffraction plane. The value of a has been estimated using the data recorded from two different orders of reflection of the same plane, i.e. $(300)$ and $(100)$. In the same time, for the estimation of $c$ the data related to the $\left(\begin{array}{ll}0 & 0\end{array}\right)$ and $(004)$ order of reflection were used. A particle can be composed by crystallites that determine its structural order. If the crystallites are small, they will be more giving the particle a structural disorder (amorphous structure). In this case, $X$-rays will be diffracted in every direction and the resulting peak on the spectrum would be broad. On the other side, if the crystallites are large, they will be present in lower amounts originating structurally more ordered sample. In this situation, X-rays would be diffracted more or less in the same direction generating narrow and sharp XRD peaks. Thus, the smaller the crystallite size, the more amorphous the particles. Using Scherrer's equation (3), the crystallite size $L$ of apatite could be estimated as ${ }^{[310]}$

$L=k \cdot \lambda / \beta \cdot \cos \vartheta$

where $\mathrm{k}$ is the broadening constant varying with the crystal habit that is assumed to be $k=0.9$ for elongated apatite crystallites, ${ }^{\left[{ }^{311]}\right.}$ while $\beta$ is the full width at half maximum (FWHM) of the peak for the chosen reflection plane. This value is the width of the 
diffraction peak (in radians) at half-way height between the background signal and the peak maximum. The determination of $\beta$ was based on three spectra per material, including silicon for instrumental broadening estimation (explained below). For a better measurement of $\beta$, the background noise was removed (cubic spline method) and a pattern smoothing algorithm (parabolic Savitzky-Golay filter set at 15 points) was applied. This value was then adjusted to consider the effect of the instrumental broadening of the XRD machine, which can be estimated by measuring a standard silicon sample and considering its diffraction peak related to the reflection plane (1 1 1). ${ }^{[312]}$ Thus it was estimated as

$\beta=\operatorname{sqrt}\left(\beta_{\mathrm{m}}^{2}-\beta_{\mathrm{i}}^{2}\right)$

where $\beta_{\mathrm{m}}$ is the observed FWHM at the chosen plane for apatite and $\beta_{\mathrm{i}}$ is the FWHM for the standard silicon. ${ }^{[313]}$ In the determination of $L$, we assumed that the lattice strain is negligibly small[312] and, since in hydroxyapatite and biological apatite the largest dimension is parallel to the $c$-axis, the $\left(\begin{array}{lll}0 & 0 I\end{array}\right)$ planes were considered. In particular the $\left(\begin{array}{lll}0 & 0 & 2\end{array}\right)$ order of reflection is reported to be the most reliable peak for the determination of $L$ in apatite. ${ }^{[312]}$

\subsubsection{Preparation and characterization of nano-apatite/poly(D,L-lactide) composites}

Poly $(D, L-l a c t i d e)$ with declared molecular weight $M_{w}=52 \mathrm{kDa}$ (Phusis Matériaux Biorésorbables, Saint Ismier, France) was dissolved in acetone ( $\left.c=0.33 \mathrm{~g} \mathrm{~mL}^{-1}\right)$ and used to prepare seven composites with different contents of unsintered apatite: $0 \%$, $12.5 \%, 25 \%, 30 \%, 40 \%, 50 \%$ and $75 \%$ by weight. The apatite suspension and polylactide solution were blended, in due proportions, for four hours in a rotational ball milling system using glass beads (diameter $3-10 \mathrm{~mm}$, total beads volume $1 / 3$ of the milling room volume) at room temperature and rotational speed of $12 \mathrm{rpm}$. After evaporation of acetone we checked which apatite/polymer ratios were suitable to have solid and not brittle composites. Sodium chloride granules ( $\mathrm{NaCl}$, size 300-400 $\mu \mathrm{m}$; Merck, Darmstadt, Germany) were added to the chosen mixtures and uniformly mixed to obtain blocks having $60 \% \mathrm{v} / \mathrm{v}$. porosity. After evaporation of acetone and leaching $\mathrm{NaCl}$ granules with distilled water, porous bodies were obtained (pore size 300-400 $\mu \mathrm{m}, 60 \%$ porosity). Regular shaped porous blocks (dimension $7 \times 7 \times 7 \mathrm{~mm}$ ) and irregularly shaped granules (dimension 2-3 mm) were manufactured and sterilized by $\gamma$-irradiation (irradiation dose range 28.9-30.7 kGy, IsoTron Nederland BV, Ede, the Netherlands) for further studies. The chemistry of the composites was analyzed with FTIR after dissolving the materials in acetone and mixing them with $\mathrm{KBr}$. The FTIR protocol followed is described in §3.2.1., while the surface morphology and apatite distribution in the polymer matrix were observed with scanning electron microscopy (Philips XL 30 ESEM-FEG, Philips, Eindhoven, the Netherlands) in secondary (SEM) and backscattered electron (BSEM) modes respectively. To evaluate whether the polymer phase changed during manufacturing, we measured 
the viscosity of the polymer as supplied and the polymer phase in the prepared materials. In the case of composites, we dissolved the samples in chloroform $\left(\mathrm{CHCl}_{3}\right.$, Sigma-Aldrich, Steinhem, Germany) at the concentration of $4 \mathrm{mg} \mathrm{mL}^{-1}$. We then separated apatite particles from the polymer component through vacuum filtering with glass funnels (ROBU, Germany; borosilicate 3.3 with glass filter having porosity \#5) and PTFE membrane filter (Toyo Roshi Kaisha, Advantec, Japan; pore size $0.1 \mu \mathrm{m}$ ) and let chloroform completely evaporate to obtain the polymer samples. Afterwards, we dissolved again the filtered polymers in chloroform (Sigma-Aldrich) at a concentration of $0.1 \mathrm{~g} \mathrm{dL}^{-1}$ and measured the relative viscosity $\left(\eta_{\text {rel }}\right)$ using an Ubbelohde (ASTM) viscometer (OC, PSL-Rheotek, Burnham on Crouch, United Kingdom) at $25 \pm 0.1^{\circ} \mathrm{C}$. From $\eta_{\text {rel }}$ we could determine the inherent $\left(\eta_{\text {inh }}\right)$ and intrinsic $(\langle\eta\rangle)$ viscosity (Solomon-Ciută equation). ${ }^{[356]}$ Then, by using MarkHouwink equation, the weight average molecular weight $\left(\mathrm{M}_{\mathrm{w}}\right)$ of the polymers was calculated, as follows:[337]

$\eta_{\text {rel }}=t_{\text {pol }} / t_{\text {chlor }}$

$\eta_{\mathrm{sp}}=\eta_{\mathrm{rel}}-1$

$\eta_{\text {inh }}=\ln \left(\eta_{\text {rel }}\right) / \hat{c}$

$<\eta>=\left[\operatorname{sqrt}\left(2 \cdot\left(\eta_{\mathrm{sp}}-\ln \left(\eta_{\mathrm{rel}}\right)\right)\right)\right] / \hat{c}$

$\ln \left(\eta_{\text {inh }}\right)=\ln (K)+\bar{a} \cdot \ln \left(M_{w}\right)$ from which $M_{w}=\exp \left[\left(\ln \left(\eta_{\text {inh }}\right)-\ln (K)\right) / \bar{a}\right]$

where $t_{\mathrm{pol}}$ and $t_{\text {chlor }}$ are the measured time for the solution of polymer and of pure chloroform to flow in the viscometer respectively, and $\hat{c}$ is the polymer concentration in chloroform. The used Mark-Houwink constants related to inherent viscosity for poly $\left(\mathrm{D}, \mathrm{L}\right.$-lactide) were $K=1.8 \cdot 10^{-4} \mathrm{dL} \mathrm{g}^{-1}$ and $\bar{a}=0.72 .{ }^{[337]}$

\subsubsection{In vitro calcium ion release}

A simulated physiological solution (SPS) was prepared by dissolving $\mathrm{NaCl}$ (Merck; $\mathrm{c}=8 \mathrm{~g} \mathrm{~L}^{-1}$ ) and 4-(2-hydroxyethyl)-1-piperazineethane-sulfonic acid (HEPES) (Sigma-Aldrich; $\mathrm{c}=11.92 \mathrm{~g} \mathrm{~L}^{-1}$ ) in distilled water. The $\mathrm{pH}$ of the solution was adjusted to 7.3 with $2 \mathrm{M} \mathrm{NaOH}$ (Sigma-Aldrich). Calcium ion release was evaluated by soaking the irregularly shaped composite granules $(\mathrm{v}=0.13 \mathrm{cc})$ in $100 \mathrm{~mL}$ of SPS at $37 \pm 1^{\circ} \mathrm{C}$ for eight hours. While carefully stirring at $150 \pm 5 \mathrm{rpm}$ without touching the samples, the calcium ion concentration in SPS was recorded every minute using a calcium electrode (Metrohm 692 ISE meter, $\mathrm{Ag} / \mathrm{AgCl}$ reference electrode, Metrohm, Herisau, Switzerland).

\subsubsection{In vitro surface mineralization}

Simulated body fluid (SBF) was prepared according to Kokubo[247] by dissolving reagent grade chemicals (Merck) in distilled water strictly in the following order: $\mathrm{NaCl}$, 
$\mathrm{NaHCO}_{3}, \mathrm{KCl}, \mathrm{K}_{2} \mathrm{HPO}_{4} \cdot 3 \mathrm{H}_{2} \mathrm{O}, \mathrm{MgCl}_{2} \cdot 6 \mathrm{H}_{2} \mathrm{O}, \mathrm{CaCl}_{2}$ (Ca ion standard solution (0.1M), Metrohm) and $\mathrm{Na}_{2} \mathrm{SO}_{4}$. The fluid was then buffered to $\mathrm{pH} 7.4$ at $36.5^{\circ} \mathrm{C}$ using Tris $\left(\left(\mathrm{CH}_{2} \mathrm{OH}\right)_{3} \mathrm{CNH}_{3}\right)$ and $1 \mathrm{M} \mathrm{HCl}$. The final solution had ion concentration (in $\mathrm{mM}$ ) as follows: $\mathrm{Na}^{+}, 142 ; \mathrm{K}^{+}, 5 ; \mathrm{Mg}^{2+}, 1.5 ; \mathrm{Ca}^{2+}, 2.5 ; \mathrm{Cl}^{-}, 147.8 ;\left(\mathrm{HCO}_{3}\right)^{-}, 4.2 ;\left(\mathrm{HPO}_{4}\right)^{2-}, 1$; $\left(\mathrm{SO}_{4}\right)^{2-}, 0.5$. Porous granules of the composites $(\mathrm{n}=20$ per material, $2-3 \mathrm{~mm})$ were soaked in $200 \mathrm{~mL}$ of SBF at $37 \pm 1^{\circ} \mathrm{C}$ for two weeks. The SBF was refreshed at day 4 and 7 . After 1,2, 4, 7 and 14 days at least three granules were taken out, thoroughly rinsed with distilled water, dried, gold sputtered and observed with SEM.

\subsubsection{Animal experiments}

With the permission of the local animal care committee (Animal Center, Sichuan University, Chengdu, China; protocol \# P07015), porous blocks $(7 \times 7 \times 7 \mathrm{~mm}, \mathrm{n}=7$ per material) were implanted in paraspinal muscles of seven skeletally mature mongrel dogs (male, 1-4 years old, weight $10-15 \mathrm{~kg}$ ) for 12 weeks to evaluate the tissue reaction and osteoinductive property of the composites. The surgical procedure was performed under general anaesthesia (pentobarbital sodium, Organon, now Merck, Whitehouse Station, NJ, USA; $30 \mathrm{mg} \mathrm{kg}^{-1}$ body weight) and sterile conditions. The back of the dogs was shaved and cleaned with iodine. A longitudinal incision was made and the paraspinal muscle was exposed by blunt separation. Longitudinal muscle incisions were subsequently made with a scalpel and four separate muscle pouches were created by blunt separation (two pouches per side). The composite blocks were then placed in the pouches and the wound was closed in layers using silk sutures. After surgery, the animals received intramuscular injections of penicillin for three consecutive days to prevent infection. To monitor the onset and time course of bone formation, calcein (Sigma-Aldrich; $2 \mathrm{mg} \mathrm{kg}^{-1}$ body weight), xylenol orange (Sigma-Aldrich; $50 \mathrm{mg} \mathrm{kg}^{-1}$ body weight) and tetracycline (Sigma-Aldrich; $20 \mathrm{mg} \mathrm{kg}^{-1}$ body weight) were intravenously injected 3,6 and 9 weeks after the implantation respectively. Twelve weeks after implantation, the animals were sacrificed and the samples were harvested with surrounding tissues and fixed in $4 \%$ formaldehyde solution ( $\mathrm{pH}=7.4$; Merck) at $4^{\circ} \mathrm{C}$ for one week. After rinsing with phosphate buffer solution (PBS; Sigma-Aldrich), the samples were trimmed from surrounding soft tissues, dehydrated in a series of ethanol solutions $(70 \%, 80 \%, 90 \%, 95 \%$ and $100 \%$ $\times 2$; Merck) and embedded in methyl methacrylate (MMA, LTI Nederland, Bilthoven, the Netherlands). Non-decalcified histological sections (10-20 $\mu \mathrm{m}$ thick) were made using a diamond saw microtome (Leica SP1600, Leica Microsystems, Wetzlar, Germany). Sections for light microscopic observations were stained with $1 \%$ methylene blue (Sigma-Aldrich) and $0.3 \%$ basic fuchsin (Sigma-Aldrich) solutions 
after etching with acidic ethanol (Merck), while unstained sections were prepared for fluorescent microscope observations.

\subsubsection{Histological and histomorphometric analysis}

The stained sections were scanned (Dimage Scan Elite 5400II, Konica Minolta Photo Imaging Inc, Tokyo, Japan) to obtain low magnification images for histomorphometric analysis. The sections were then observed with light microscopy (Nikon Eclipse E200, Tokyo, Japan) to analyse the tissue reaction and bone formation. Unstained sections were observed with a fluorescent microscope (Nikon Eclipse E600, camera Nikon FDX-35) to determine the onset of bone formation. Histomorphometry was performed using Photoshop CS5 software (v12, Adobe Systems Benelux BV). The whole sample was selected as a region of interest and the corresponding number of pixels was read as ROI. Then the material and mineralized bone were pseudo-coloured and their pixels were counted as $M$ and $B$ respectively. The percentage of bone in the available space of the explants $\left(B_{p}\right)$ was then determined as

$B_{p}=100 \cdot B /(R O I-M)$

\subsection{Results}

\subsubsection{Nano-apatite physicochemical characterization}

The XRD pattern of sintered samples showed crystallized hydroxyapatite (HA), whereas the unsintered samples showed broader peaks indicating that the precipitate was more amorphous (CaP, Figure 1). The $2 \vartheta$ positions of the peaks were coincident for both sintered and unsintered apatite. They matched those of the international JCPDS 9-432 reference for hydroxyapatite and also those sperimentally measured for the mineral of human cortical bone (Table 1). The FTIR spectrum of unsintered apatite highlighted the presence of all the characteristic vibrational peaks of hydroxyapatite (i.e. sintered apatite) (Figure 1, Table 2). When compared with literature data, the unsintered apatite powder was chemically similar to the mineral of human cortical bone (Table 2). It is interesting that both FTIR and XRD spectra did not have extra peaks indicating absence of other phases or impurities. The particle dimensions were evaluated only for the unsintered apatite since it will be used to prepare the composites. HR-SEM and TEM observations (Figure 1) indicated average particle dimensions of $84 \pm 19 \mathrm{~nm}$ width and $369 \pm 41 \mathrm{~nm}$ length confirming the nano-scaled nature of the synthesized powder. Further, the morphology of apatite particles was needle-shaped (Figure 1). It is interesting that other investigations reported that human cortical bone apatite has mainly flake-like morphology (30-100 $\mathrm{nm}$ length) but needle-like minerals (over $100 \mathrm{~nm}$ length and larger than $10 \mathrm{~nm}$ ) were observed as well.[23] The Ca/P ratio of unsintered apatite, characterized by EDX, 
resulted $1.64 \pm 0.01$, which is in line with the reported ratio of synthetic apatites (i.e. $1.6-1.67)^{[307,314]}$ and falls within the interval of $\mathrm{Ca} / \mathrm{P}$ ratio normally measured in human minerals (i.e. dentin $\sim 1.61$, enamel $\sim 1.63$ and cortical bone $\sim 1.71$ ). ${ }^{[309]}$
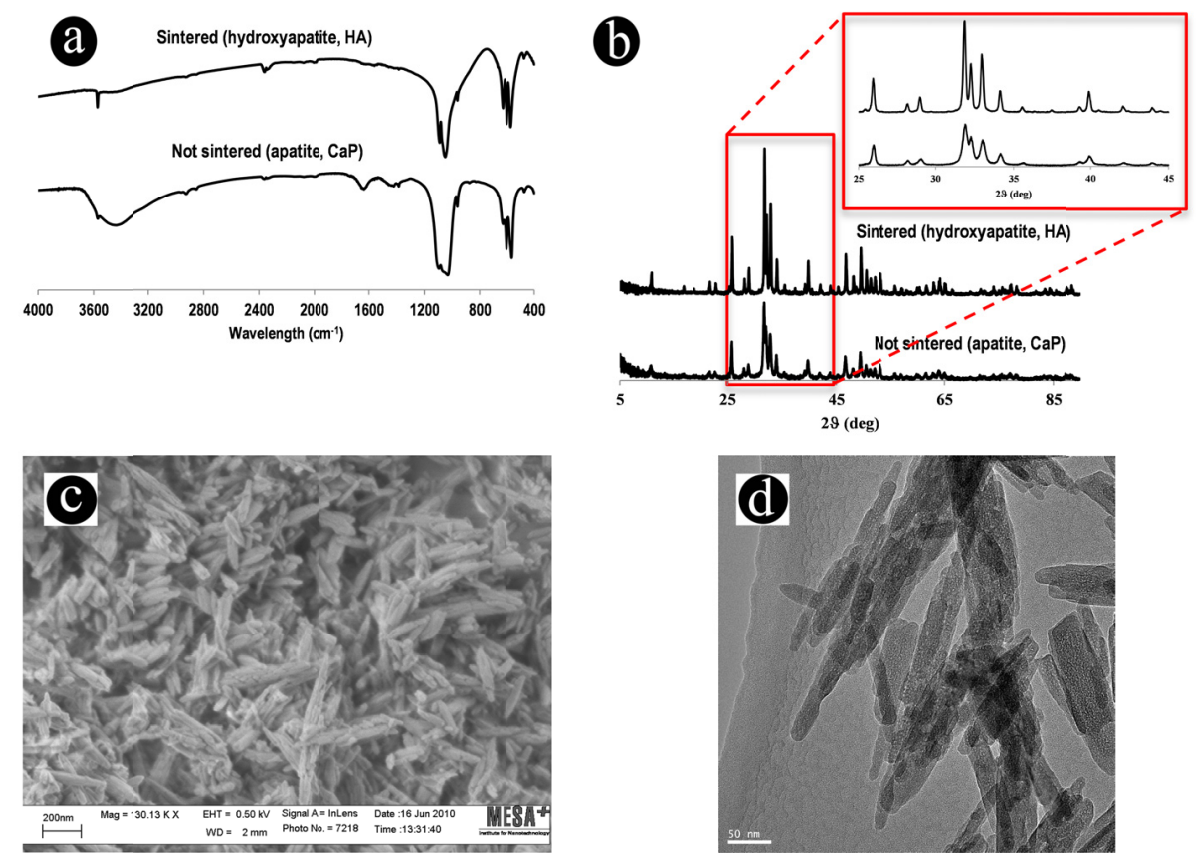

Figure 1. (a) FTIR and (b) XRD spectra for sintered and unsintered apatite. In the red box is the detail in $2925-45$ deg to show the broader peaks of unsintered apatite as compared to those of sintered apatite. (c) HR-SEM and (d) TEM pictures of the unsintered apatite. Scale bars for SEM and TEM images are $200 \mathrm{~nm}$ and $50 \mathrm{~nm}$ respectively.

\subsubsection{Nano-apatite structural characterization}

Calculations on the diffractometer data led to unit cell parameters for sintered apatite close to those characteristic for synthetic hydroxyapatite, while those calculated for the unsintered one were similar to the unit cell parameters measured in bone mineral from human ilium (Table 3). This further confirms that the sintering process of the precipitated apatite powder led to phase pure hydroxyapatite. However, the calculated crystallite size of unsintered apatite was $L=51.3 \pm 4.4 \mathrm{~nm}$, differing from that reported for the mineral extracted from human cortical bone $(\sim 25$ $37 \mathrm{~nm})$ along the $c$-axis considering the same reflection plane $(002),{ }^{[309,312,315]}$ but close to that reported for not thermally treated apatite powders $(\sim 50-54 \mathrm{~nm}){ }^{\left[{ }^{316]}\right]}$ It is interesting that thermally treating apatite is reported to lead to larger crystallite size (i.e. $\sim 95-98 \mathrm{~nm}$ ). ${ }^{[313]}$ This may be explained with the fact that the synthesized and 
unsintered apatite is less amorphous than bone apatite because it does not contain impurities such as other ions (e.g. carbonate), but it is more amorphous than thermally treated apatites. This conclusion is supported also by the typical X-ray diffractometer patterns of bone mineral available in literature, which peaks are much broader than those observed in unsintered apatite.

\subsubsection{Composites characterization}

We observed that apatite contents exceeding $50 \%$ wt. led to brittle composites since, after solvent evaporation, their bulk mass presented cracks and could be easily broken (Figure 2). Basing on these observations, we decided to use composites with 0, 10, 20 and 40\%wt. apatite content for further studies (i.e. $0 \%$ CaP, $10 \% \mathrm{CaP}, 20 \%$ $\mathrm{CaP}$ and $40 \% \mathrm{CaP}$ respectively).

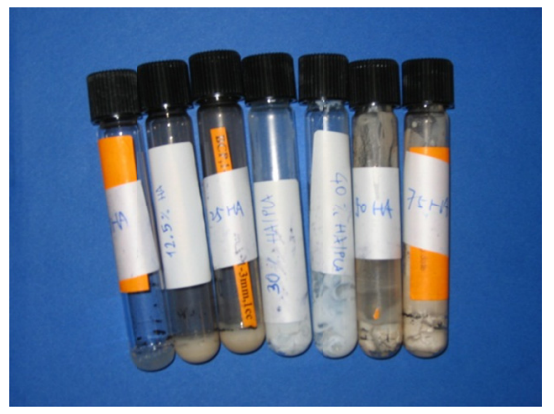

Figure 2. Loading poly $(\mathrm{D}, \mathrm{L}-$ lactide) with excessively high content of apatite, i.e. more than $50 \%$ wt., led to brittle composites. In the tubes, from left to right, are the composites containing $0 \%, 12.5 \%, 25 \%, 30 \%, 40 \%$, $50 \%$ and $75 \%$ wt. apatite content respectively. Note that the materials with 50 to $75 \%$ wt. apatite were brittle after acetone evaporation, and had many cracks.

The nano-apatite distribution in the composites was observed using BSEM and it was seen that the apatite particles were quite homogeneously distributed throughout the composites (Figure 3), even though apatite agglomerates (2 to $6 \mu \mathrm{m}$ size) could be observed. This might be caused by inhomogeneous mixing in the ball-milling system or by the solvent evaporation that may have shifted apatite particles leading to their agglomeration before the complete hardening of the polymer. At low magnification (25x) SEM, the blocks of all compositions had similar porous structure, regardless of the apatite amount (Figure 4). At higher magnification (10,000x), they appeared slightly different due to the presence of apatite particles, which created rougher surface microstructures at high apatite contents (Figures 4). FTIR analysis showed an increase in intensity of the characteristic apatite peaks (i.e. $~ 564-566 \mathrm{~cm}^{-1}$ and $\sim 603$ $604 \mathrm{~cm}^{-1}$ ) with the increase of apatite content in the materials while a decrease of the main polylactide peak $\sim 1100 \mathrm{~cm}^{-1}$ was seen demonstrating that apatite was added to the polymer in the expected trend (Figure 5). No significant effects of the manufacturing process on the polymer molecular weight were seen in any of the prepared materials (Table 4). 


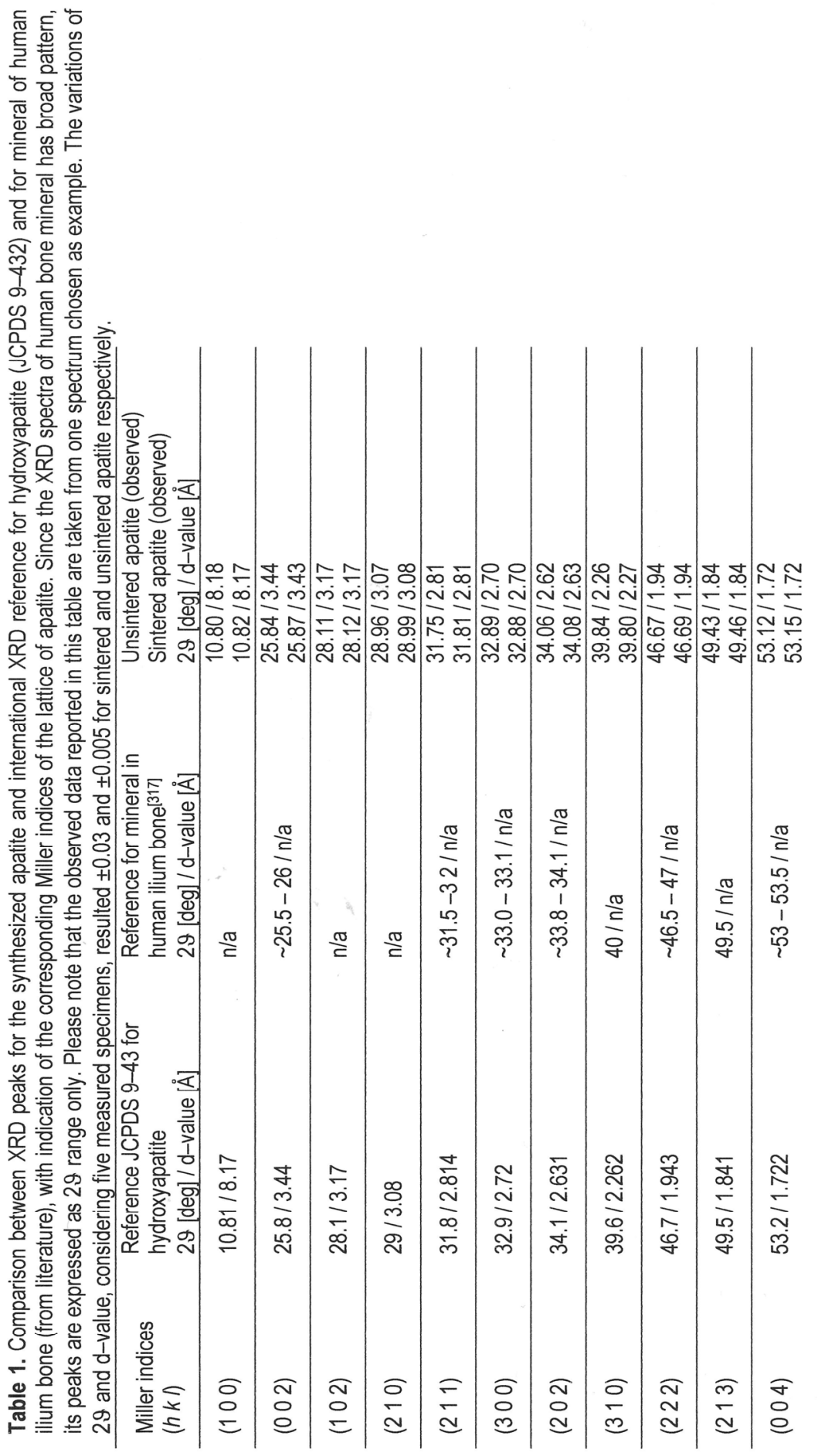




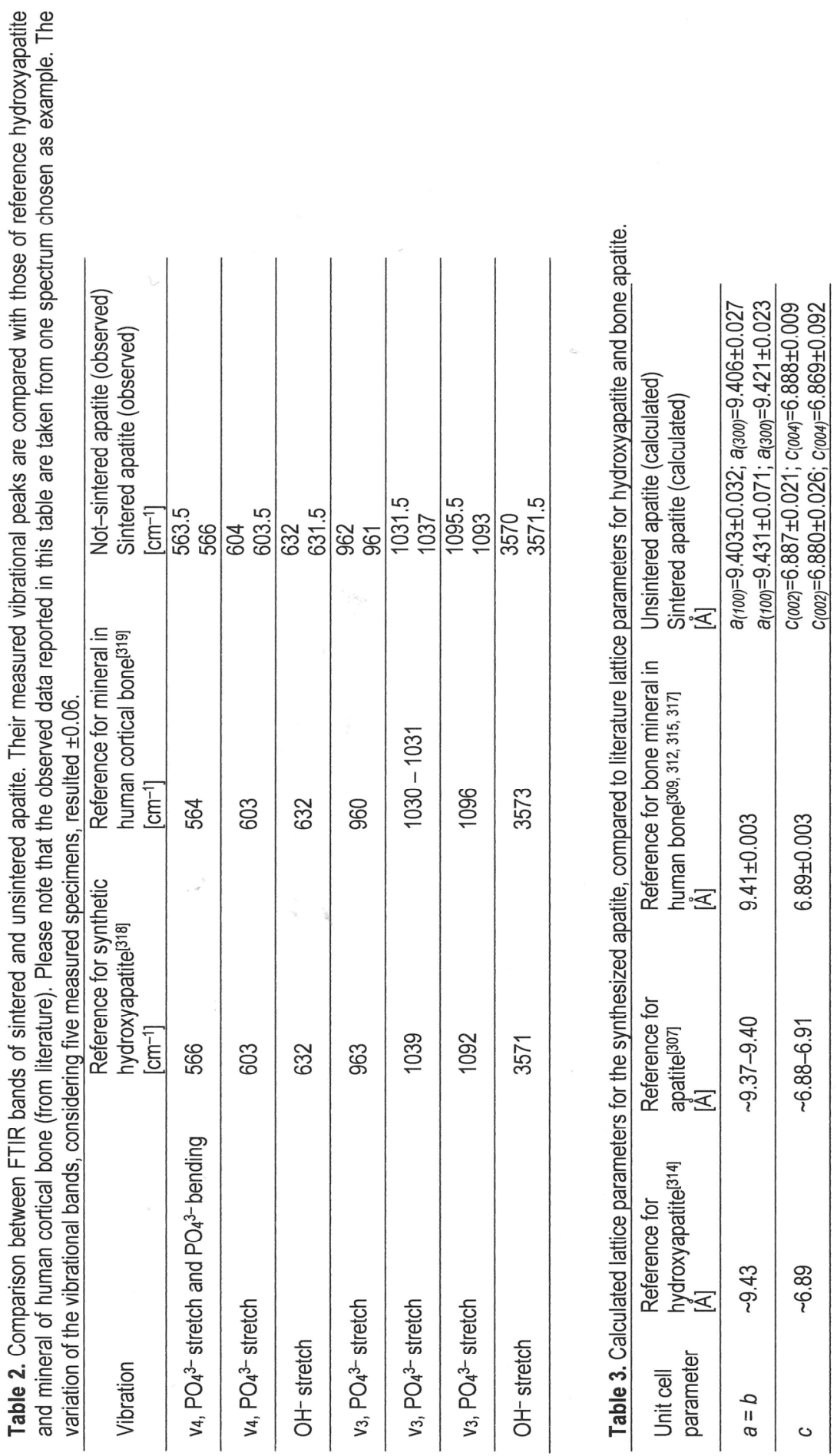



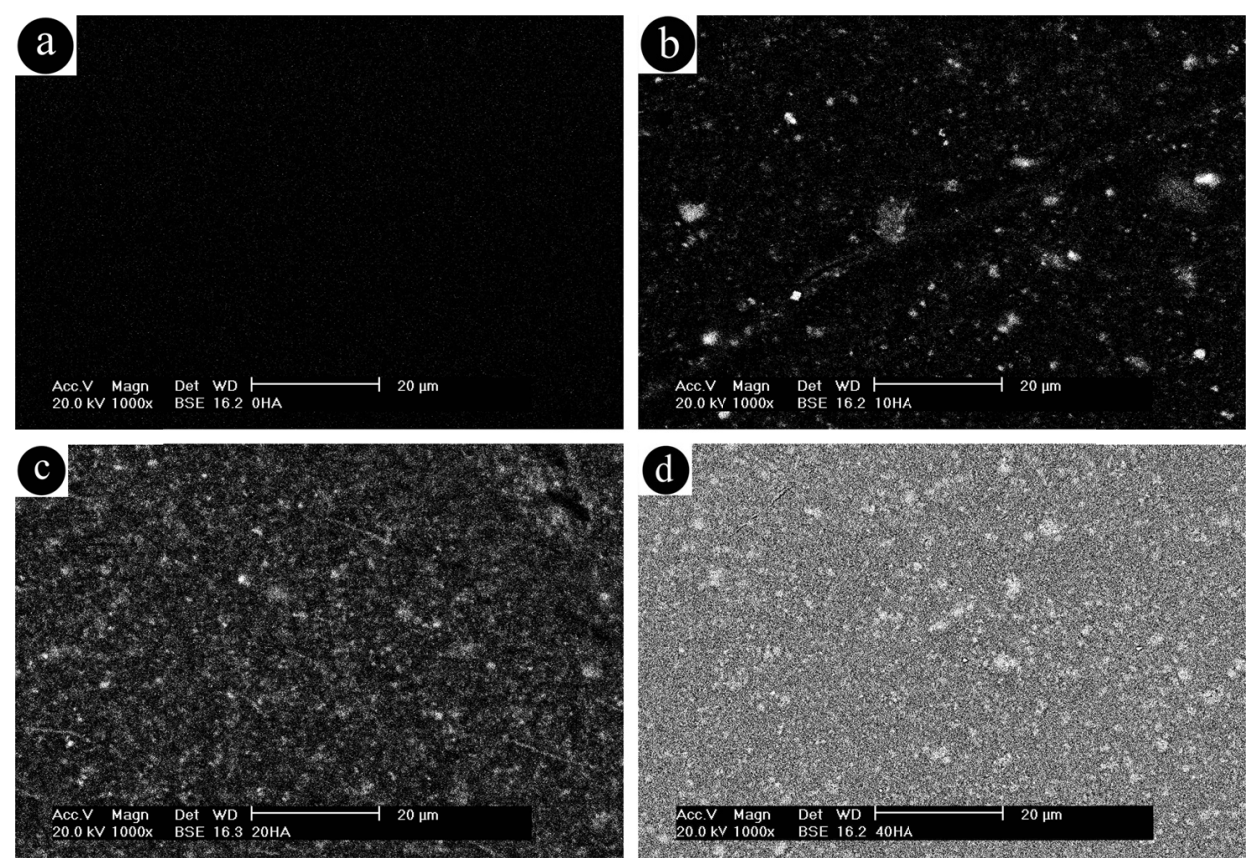

Figure 3. BSEM pictures showing the apatite particles distribution in the polylactide matrix for (a) $0 \% \mathrm{CaP}$, i.e. poly(D,L-lactide), (b) $10 \% \mathrm{CaP}$, (c) $20 \% \mathrm{CaP}$ and (d) $40 \% \mathrm{CaP}$ specimens. Polymer matrix is black, while apatite particles are white.

Table 4. Ubbelohde measurements of inherent $\left(\eta_{\text {inh }}\right)$ and intrinsic $(<\eta>)$ viscosity, and calculated weight average molecular weight $\left(\mathrm{M}_{\mathrm{w}}\right)$ for the polymer as supplied and after processing in acetone with apatite particles. Statistical comparison is done on $\mathrm{M}_{\mathrm{w}}$ and is expressed in terms of $\mathrm{p}$-value.

\begin{tabular}{llllll}
\hline & As supplied & $0 \% \mathrm{CaP}$ & $10 \% \mathrm{CaP}$ & $20 \% \mathrm{CaP}$ & $40 \% \mathrm{CaP}$ \\
\hline$\eta_{\text {inh }}\left[\mathrm{dL} \mathrm{g}^{-1}\right]$ & $0.47 \pm 0.01$ & $0.44 \pm 0.02$ & $0.46 \pm 0.01$ & $0.47 \pm 0.01$ & $0.45 \pm 0.03$ \\
$<\eta>\left[\mathrm{dL} \mathrm{g}^{-1}\right]$ & $0.48 \pm 0.02$ & $0.44 \pm 0.01$ & $0.46 \pm 0.03$ & $0.48 \pm 0.02$ & $0.46 \pm 0.01$ \\
$\mathrm{M}_{\mathrm{w}}[\mathrm{kDa}]$ & $56.3 \pm 1.7$ & $51.7 \pm 1.3$ & $54.7 \pm 1.1$ & $56.9 \pm 0.9$ & $53.5 \pm 1.1$ \\
\hline p, ANOVA & $>0.07$ for all comparison combination except when comparing the polymer as \\
& supplied with $0 \% \mathrm{CaP}$ where & $\mathrm{p}<0.045$. In general, differences were not seen. \\
\hline
\end{tabular}

\subsubsection{In vitro calcium ion release}

Due to the increase of calcium ion concentration in SPS, a decrease in the composite dissolution rate during time was seen for all samples. Moreover, the amount of calcium ions released was dependent on the apatite content in the material: the more apatite in the material, the faster the calcium ion release and the more ions released (Figure 5). After eight hours, the calcium ions released from the materials were $5.6 \pm 0.4,2.5 \pm 0.4$, $1.7 \pm 0.3$ and $0.1 \pm 0.1 \mathrm{ppm}$ for $40 \% \mathrm{CaP}, 20 \% \mathrm{CaP}, 10 \% \mathrm{CaP}$ and $0 \% \mathrm{CaP}$ respectively.

\subsubsection{In vitro surface mineralization}

SEM images showed that mineralization of the surface occurred in vitro after two days for all $40 \%$ CaP specimens (Figure 6). On the contrary, in the materials with lower 
apatite contents no mineralization was seen within 14 days (Figures 6). The mineralization increased with time on the $40 \% \mathrm{CaP}$ surface, as indicated by both the extension and the thickness of the covering calcified layer (Figures 6 ).

\subsubsection{Ectopic bone formation}

A total of seven samples per material were intramuscularly implanted in seven dogs. After 12 weeks, all samples were retrieved and they were surrounded by a thin layer of connective tissue and then muscle tissue. As shown in the histological overview (Figure 6 ), only the $40 \% \mathrm{CaP}$ specimens retained their shape after 12 weeks of implantation (Figure 7), while all samples with lower CaP content collapsed (Figures 7a, 7b, 6c). It was also observed that only $40 \% \mathrm{CaP}$ implants had de novo bone tissue in their pores $(n=7)$ (Figure 7). Closer observation (Figure 8) showed that both non-mineralized and mineralized bone had formed tight to the pore surface of all $40 \% \mathrm{CaP}$ implants. Active osteoblast-like cells were present on the outer surface of the newly formed bone (Figure 8), indicating that there was still active bone formation after 12 weeks of implantation. At the same time, osteocytes were observed within lacunae in the mineralized bone (Figure 8). Histomorphometry analysis quantified the area percentage of bone in the available space of $40 \%$ CaP as $4.9 \pm 4.5 \%$ (Table 5). Fluorescent microscopy showed that all $40 \%$ $\mathrm{CaP}$ specimens contained three colours: green, red and yellow (Figure 9). The colour green (calcein injected at week 3 ) was seen within the composite material and may indicate in vivo mineralization of the implants, and not bone formation. However, the presence of calcein in the material may also mean adsorption of the fluorochrome on the composite at free binding sites formed after probable degradation of the composite. Red (xylenol orange injected at week 6) and yellow (tetracycline injected at week 9) fluorescent labels were seen within bone tissue deposited on the material surface and indicate that bone formation had started between 3 and 6 weeks (Figure 9) and had continued until at least 9 weeks after implantation (Table 5).

\subsection{Discussion}

In the present study we added nano-sized apatite into low molecular weight polylactide and obtained relatively homogenous composites with various apatite contents. We observed that the solvent-based manufacturing method did not alter the properties of the polymer (i.e. molecular weight) and it is not expected it would influence on the chemistry of both polymer and apatite. All implants of $0 \% \mathrm{CaP}, 10 \% \mathrm{CaP}$ and $20 \% \mathrm{CaP}$ collapsed within 12 weeks in vivo, while $40 \% \mathrm{CaP}$ retained its three-dimensional porous shape. Interestingly, the implants containing the higher percentage of calcium phosphate apatite particles induced bone formation following intramuscular implantation. Since this phenomenon was shown in an ectopic implantation site, this can be defined as osteoinduction.[221] 

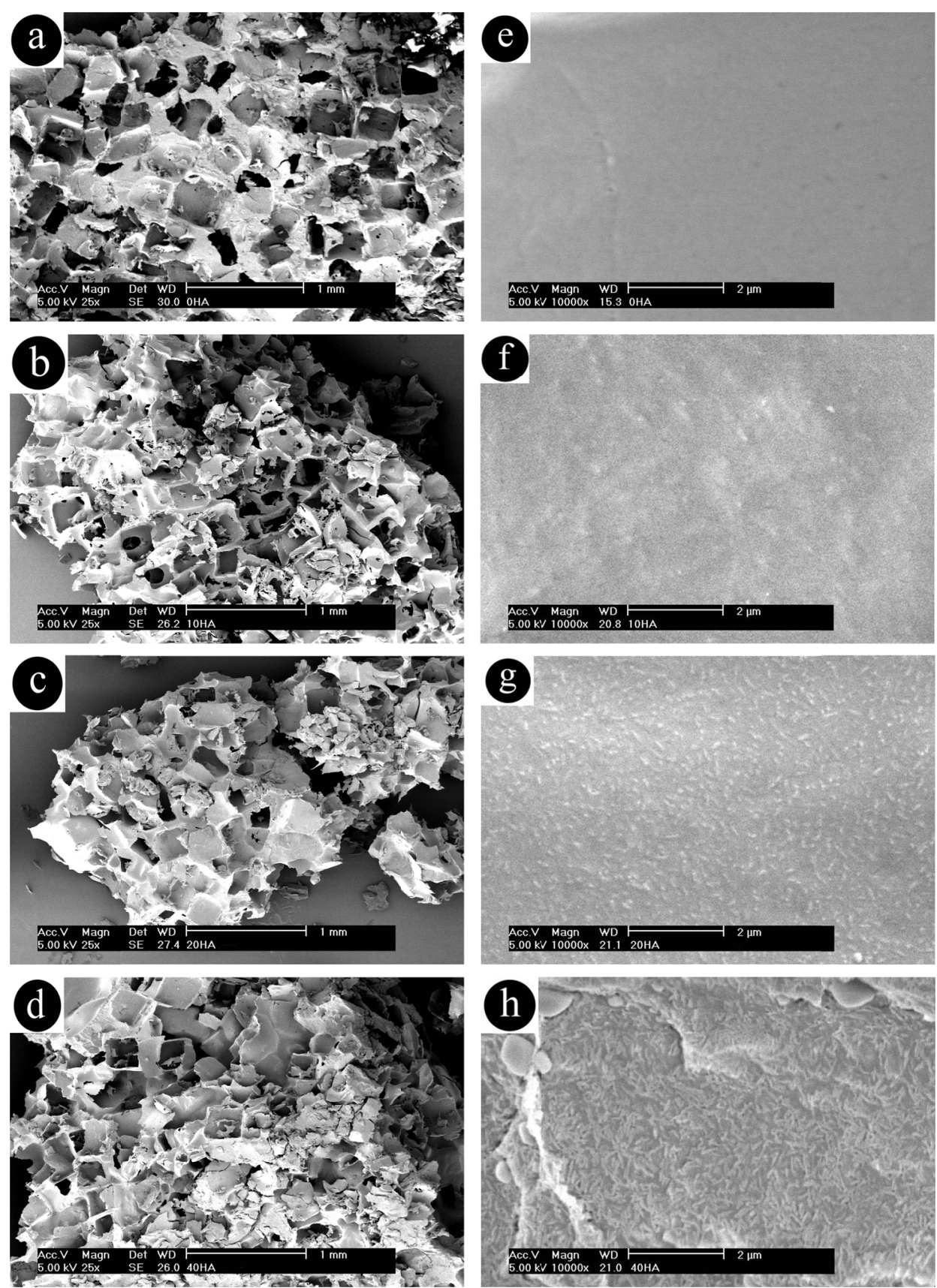

Figure 4. SEM pictures showing the porous sample of the composites at low $(25 \times)$ and high $(10,000 \times)$ magnifications for (a) $0 \% \mathrm{CaP}$, (b) $10 \% \mathrm{CaP}$, (c) $20 \% \mathrm{CaP}$ and (d) $40 \% \mathrm{CaP}$ samples. Detail of the surface of (e) $0 \% \mathrm{CaP}$, (f) $10 \% \mathrm{CaP}$, (g) $20 \% \mathrm{CaP}$ and (h) $40 \% \mathrm{CaP}$ samples. 
Thus, filling the polymer with high percentage (i.e. up to $40 \%$ wt.) of nano-sized calcium phosphate apatite particles can render poly( $\mathrm{D}, \mathrm{L}$-lactide) osteoinductive. This property could be relevant when implanting these materials in large bone defects where osteoinduction is required. $[86,238,304]$ The bone induction in $40 \% \mathrm{CaP}$ started between 3 and 6 weeks after implantation, which is a time comparable to other osteoinductive materials such as biphasic calcium phosphate $(B C P)$ and hydroxyapatite $(\mathrm{HA})$, used in the same animal models. ${ }^{[219]}$ However, at present it is not fully clear what triggers osteoinduction in the $40 \% \mathrm{CaP}$ composites.
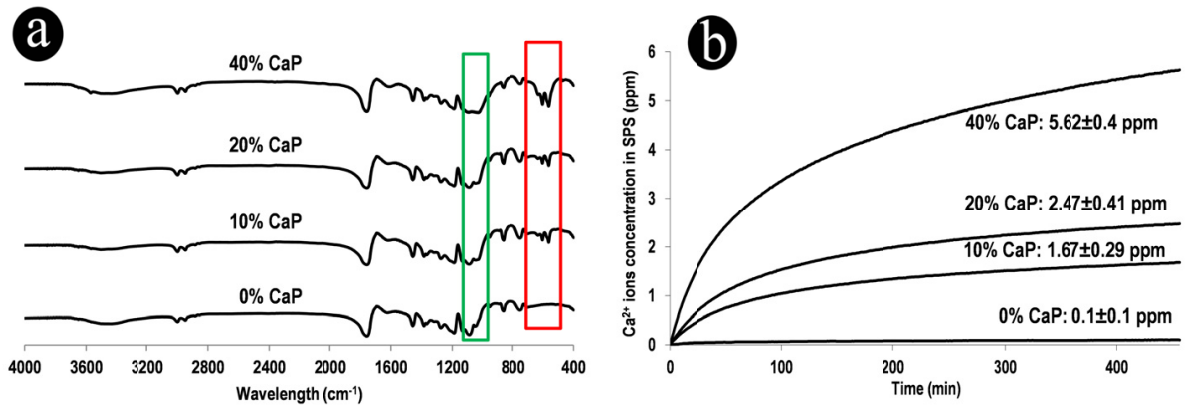

Figure 5. (a) FTIR spectra of the composites. It can be observed that the intensity of the apatite characteristic peaks increases with the apatite content in the composites (red box), while one of the peaks of poly $(D, L-l a c t i d e)$ disappears with the decrease of the polymer content (green box). (b) Changes of calcium ion concentration of SPS when the samples were soaked in it for eight hours. On the diagram the final average calcium ion concentrations in SPS are reported for each material.
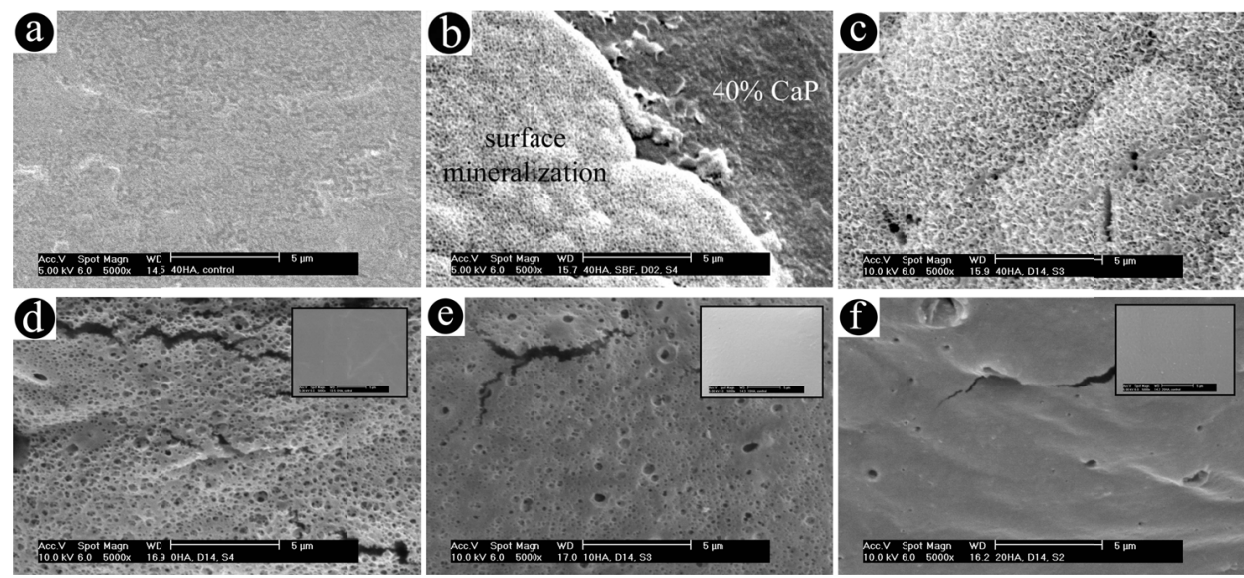

Figure 6. Surface mineralization was seen after two days on $40 \% \mathrm{CaP}$, while it did not occur on the othe composites after two weeks. (a) 40\% CaP surface before soaking in SBF and (b) $40 \% \mathrm{CaP}$ after two days in SBF when surface mineralization was occurring. (c) $40 \% \mathrm{CaP}$ after 14 days when the surface was completely covered by thick mineralized layers. Images (d), (e) and (f) show $0 \%, 10 \%$ and $20 \% \mathrm{CaP}$ respectively after 14 days in SBF. In the small boxes are the starting surfaces of $0 \%, 10 \%$ and $20 \% \mathrm{CaP}$. 
Surface mineralization could play a role. At the end of the Sixties, a polymer (i.e. polyHEMA) was reported to induce bone formation under the skin of pigs and it was observed that the surface of the polymer had mineralized before bone formation. ${ }^{[221]} \mathrm{A}$ connection of in vitro surface mineralization with material-directed bone induction has been proposed. Osteoinductivity in muscle of dogs of titanium implants, with surfaces that did or did not mineralize in vitro in SBF, was studied.

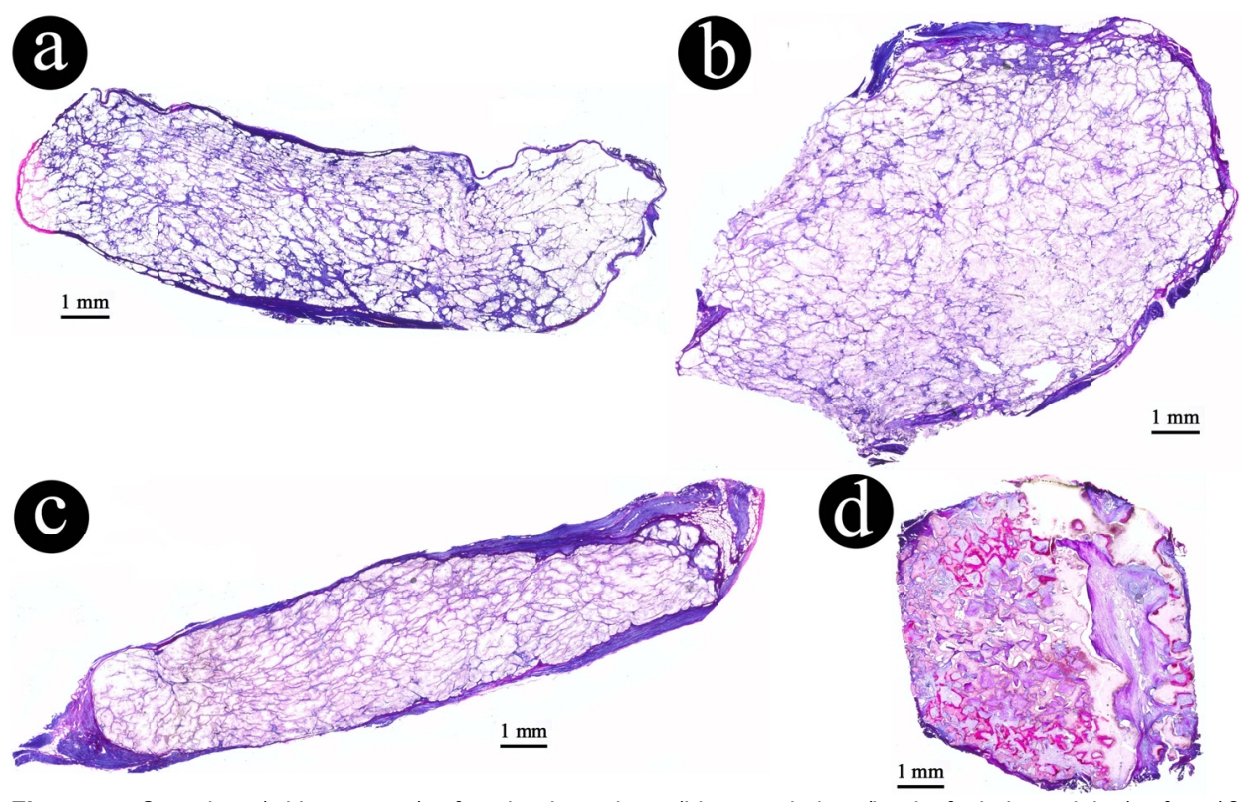

Figure 7. Overview (with scanner) of stained sections (blue methylene/basic fuchsin staining) after 12 weeks implantation. (a) $0 \% \mathrm{CaP}$, (b) $10 \% \mathrm{CaP}$, (c) $20 \% \mathrm{CaP}$ and (d) $40 \% \mathrm{CaP}$ implants. It can be observed that bone formation occurred only in $40 \% \mathrm{CaP}$ composites (d) while the porous structure of $0 \% \mathrm{CaP}, 10 \%$ $\mathrm{CaP}$ and $20 \% \mathrm{CaP}$ implants collapsed (a, $\mathbf{b}$ and $\mathbf{c})$ : no porous architecture of the materials is clearly visible.

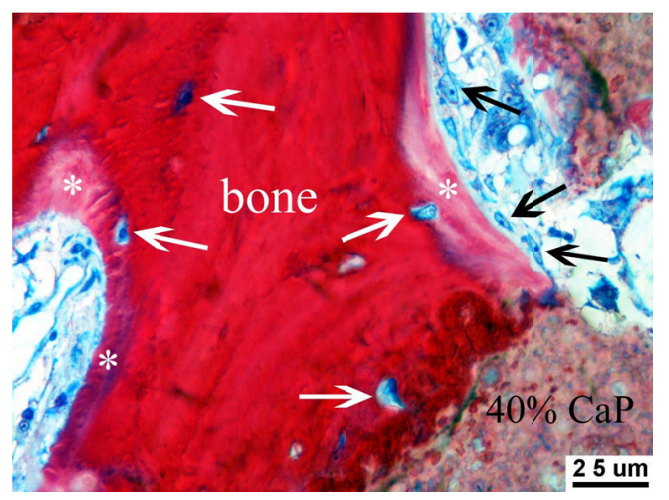

Figure 8. Bone induction in $40 \% \mathrm{CaP}$ after 12 weeks of intramuscular implantation. An active, but not yet mineralized, bone formation zone with a definite osteoblast-seam (black arrows) covering an osteoid layer $\left({ }^{*}\right)$ is visible. The inner part of the trabeculum is an immature woven and mineralized bone with the typical large and polygonal osteocytes (white arrows). 
Table 5. Bone incidence, histomorphometry and fluorescent results after 12-week implantation in dogs.

\begin{tabular}{lllll}
\hline & $0 \% \mathrm{CaP}$ & $10 \% \mathrm{CaP}$ & $20 \% \mathrm{CaP}$ & $40 \% \mathrm{CaP}$ \\
\hline Bone incidence & $0 / 7$ & $0 / 7$ & $0 / 7$ & $7 / 7$ \\
\hline Bone in available space [\%] & $0 \pm 0$ & $0 \pm 0$ & $0 \pm 0$ & $4.9 \pm 4.5$ \\
\hline Time for bone formation & \multicolumn{5}{c}{ no bone formation } & between 3-6 weeks \\
\hline
\end{tabular}
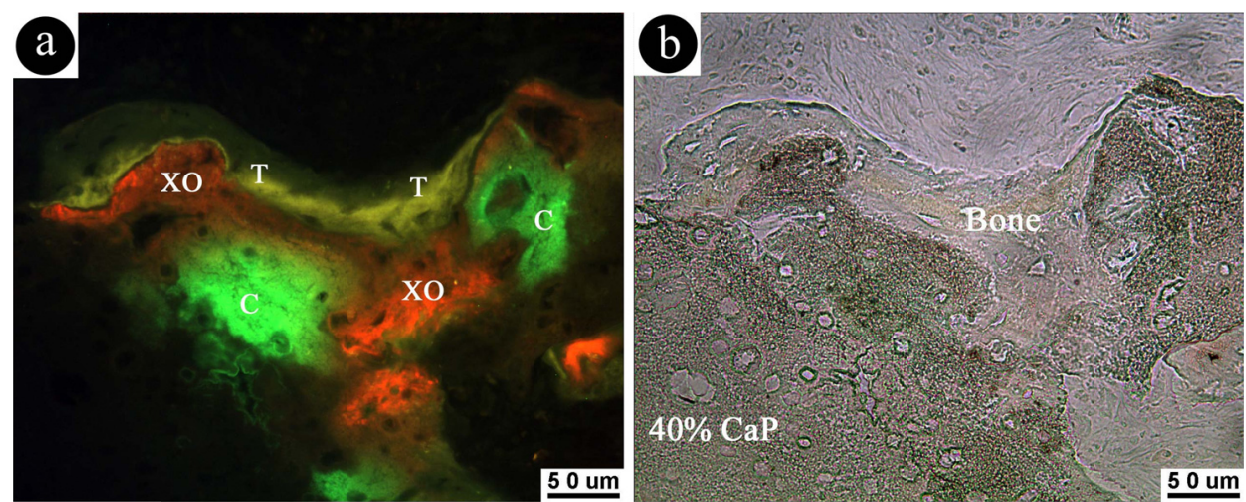

Figure 9. By comparing micrographs of the same region of an unstained section under fluorescent (a) and transmitted light (b), correlations between the composite $(40 \% \mathrm{CaP})$ and the zone coloured in green (calcein, $\mathrm{C}, 3$ weeks), and between the bone tissue (Bone) with the zones coloured in red (xylenol orange, XO, 6 weeks) and yellow (tetracycline, T, 9 weeks) are possible. This leads to the conclusion that bone started to form after 3 weeks but before 6 weeks from the implantation, while surface mineralization may have started to occur during the first 3 weeks.

The results showed that titanium implants capable of forming apatite layers in SBF also induced bone formation in vivo. Conversely, those that did not mineralize in vitro also did not trigger any bone formation. ${ }^{[234]}$ We showed a similar relation between in vitro surface mineralization and bone induction in our composites. Amongst the composites tested in vitro in $\mathrm{SBF}$, only the surface of $40 \% \mathrm{CaP}$ composites could mineralize. It is well-known that apatite-based materials contain functional groups that allow the spontaneous formation of mineralized layers onto their surfaces. ${ }^{[245]}$ Having more apatite exposure on its surface, $40 \% \mathrm{CaP}$ had the fastest surface mineralization than the other composites here studied. We cannot now conclude that 0,10 and $20 \%$ CaP composites will never mineralize: it might be that, by virtue of their lower apatite contents, they require longer time to mineralize. Our results are in line with the findings that micro-sized hydroxyapatite/poly(L-lactide) composites rapidly formed (within one week) a mineralized layer onto their surfaces when immersed in SBF ${ }^{[320]}$ Similarly to what observed previously with polyHEMA, ${ }^{221]} 40 \% \mathrm{CaP}$ may have mineralized in vivo before the starting of bone formation (Figure 9). Thus, high contents of nano-sized apatite may have enhanced surface mineralization of the $40 \% \mathrm{CaP}$ composites in vivo, and therefore allowed bone induction. This is in line with the suggestion that in vivo surface 
mineralization generates a suitable environment for inducible cells to form bone ${ }^{[217]}$ and allows osteoinduction occur. [248, 249]

Besides in vivo surface mineralization, protein adsorption may also play a role in triggering ectopic bone formation. It has been reported that a bioinert $\mathrm{Al}_{2} \mathrm{O}_{3}$ ceramic adsorbs proteins and induces bone formation in muscle of dogs while it was not shown to surface calcify in vitro or in vivo. ${ }^{[251]}$ It has also been shown that calcium phosphate materials have high affinity for proteins (e.g. bone morphogenetic proteins, BMPs)[228, 249, ${ }^{326]}$ and that composites with high content of HA adsorb more proteins. ${ }^{[42]}$ Based on these assumptions, it may well be that $40 \% \mathrm{CaP}$ composites could have adsorbed higher amount of proteins (including BMPs) from the surrounding body fluids. Such proteins may have then contributed to instruct (stem) cells to osteogenically differentiate and trigger inductive bone formation. Conversely, composites with lower apatite content would not adsorb enough proteins to start osteoinduction. However, the proteins that are adsorbed and play a potential role in $40 \% \mathrm{CaP}$ osteoinduction need to be evaluated in further studies.

Another aspect regarding inductive bone formation in $40 \% \mathrm{CaP}$ may be ion release (especially calcium) from the composites. Calcium is believed to be an extra-cellular signaling molecule in bone ${ }^{[321-323]}$ and it has been shown that ions released from calcium phosphate materials do not only enhance the bioactivity of materials ${ }^{[227,228,324]}$ but also the proliferation, differentiation and mineralization of osteogenic cells. ${ }^{[321-323]} \mathrm{We}$ observed higher amounts of calcium ions released in vitro from $40 \% \mathrm{CaP}$ composites compared to the others and, as shown in this study, only $40 \% \mathrm{CaP}$ gave rise to inductive bone formation, indicating a possible role of the amount of calcium ion released in osteoinduction. The higher release of calcium ions from $40 \% \mathrm{CaP}$, as compared to the other three considered materials, might be due to the fact that it exposes more apatite on its surface. Moreover, at the contact with surrounding fluids, the exposed apatite may have dissolved releasing calcium. Besides this, hydrolysis of the polymer matrix could have occurred further exposing apatite from its bulk and enhancing ion release. Thus the large amount of calcium released may have triggered $40 \%$ CaP composite-related osteoinduction. ${ }^{[325]}$ However, the importance that calcium ions may have in triggering heterotopic bone formation still needs to be understood and demonstrated.

Finally, the surface micro-structural changes due to the increased apatite content in the four composites could have played a role as well. Several studies have reported that controlled micro- or nano-structures do not only have positive effects on the differentiation of (mesenchymal) stem cells into osteogenic cells, ${ }^{[195]}$ but also influence protein adsorption and ion release. ${ }^{[217,228,326]}$ As shown in Figure 4 , the $40 \% \mathrm{CaP}$ has a rougher surface micro-structure as compared to those composites with lower apatite contents. Previous studies have reported that specific surface micro-structure on a chemically unaltered ceramic can render osteoinductive ceramics. $[217,228,237]$ Further, we 
have shown that porous tantalum, coated with biomimetic octacalcium phosphate layers having micro-structure, is osteoinductive when implanted in muscle of dogs. ${ }^{[231]}$ The observed change in surface micro-structure with $40 \% \mathrm{CaP}$ by exposed nano-apatite particles could have been further enhanced during hydrolysis of the polymer phase. Implants having less than $40 \% \mathrm{CaP}$ collapsed and no bone formation occurred. Although the lack of a porous architecture may have inhibited bone formation, [226, 228, 327] we have recently shown that macro-porosity of a scaffold is not a prerequisite for bone induction. ${ }^{[217]}$ This suggests that the absence of bone formation in composites with lower contents of $\mathrm{CaP}$ apatite is due to the apatite content and not to the lack of a porous architecture. However, the current results cannot conclusively assign inductive bone formation in $40 \% \mathrm{CaP}$ to surface mineralization, protein adsorption, calcium ion release and/or surface micro-structure. It may well be that these features played a combined role in triggering $40 \% \mathrm{CaP}$ composite-related osteoinduction. Nonetheless, the influence of nano-apatite on the osteoinductive properties of the composites was shown. Forty weight percent nano-apatite content provided the composite with a micro-structured surface, enhancing ion release and surface mineralization, which ultimately led to ectopic bone formation in the dorsal muscle of dogs. Future studies will focus on enhancing mechanical properties and understanding the process of material-directed osteoinduction.

\subsection{Conclusions}

In the quest to develop the ideal bone graft material, we have prepared an osteoinductive composite based on poly(D,L-lactide) and nano-sized apatite. The influence of nano apatite on the osteoinductive properties of the composites was shown. A composite containing 40\%wt. nano-apatite had microstructured surface, which enhanced ion release and surface mineralization that ultimately led to ectopic bone formation in muscle of dogs. However, studies on enhancing mechanical properties by keeping the osteoinduction property are required. Besides this, a better understanding of the material-related osteoinduction phenomenon needs further investigations. 



\section{CHAPTER 4}

Controlling dynamic mechanical and degradation properties in instructive composites 



\section{Remarks}

This Chapter will introduce to composite materials comprising apatite particles in polymer, which were prepared with extrusion that will be used throughout the next Chapters of this thesis. The extrusion process was optimized during pilot studies (not reported in this thesis) according to some requirements. The main requirements were: 1) maximize the homogeneity of apatite distribution in the polymer matrix, 2) minimize the degradation due to processing of the polymer phase, and 3) facilitate the manufacturing steps (e.g. the green body should flush out of the extruder in a solid state, and not as quasi-liquid). To reach an equilibrium amongst these requirements, the extrusion temperature, the screw rotatory speed and the extrusion duration were the optimized parameters. A range of various polymers was used and, on the basis of the results, some were chosen to manufacture the composites in this thesis.

\subsection{Introduction}

Ancient people already treated bone fractures by realigning the parts and joining them with metal sticks inserted into the medullary canal. An example is the Egyptian mummy Usermontu (656-525 BC), which was found with a metallic leg prosthesis in its femora. ${ }^{[170]}$ During the last century metals and their alloys have been used in fixation devices and supporting structures for fracture healing and joint replacement, $\left[{ }^{[28,329]}\right.$ such as stems and acetabulum cups of various commercial hip prostheses. It is well-known that bone, in response to the surrounding mechanical stimuli, adapts its anatomical structure through natural growth and resorption processes. ${ }^{[330]}$ Therefore, by virtue of their higher stiffness than bone tissue, metalbased implants cause mechanical stress shielding in bone provoking its resorption, ultimately leading to prosthesis loosening and/or osteolysis. ${ }^{[331]}$

To avoid mechanically-induced bone resorption, scientists have striven to develop biomaterials fully or partially mimicking the bi-phasic composition of bone and its structure. In general, bone tissue comprises a collagenous matrix reinforced by nanoparticles of carbonated apatite. ${ }^{[21,22]}$ Synthetic or natural polymers have viscoelastic characteristics and may be used alone in sites where mild mechanical stresses exist, such as in soft tissues like cartilage or tendons. On the contrary, in sites where stiffness is required together with damping abilities such as bone, filling polymers with inorganic particulate may be an interesting solution. Some scientists replicated in vitro the process of collagen mineralization and obtained materials chemically and hierarchically mimicking bone tissue, ${ }^{[213]}$ while others synthesized fibrous silk macroporous blocks containing calcium phosphate. ${ }^{[214]}$ Micro- or nano- (hydroxy-)apatite has been added to synthetic polymers generating materials not only with mechanical characteristics comparable to those of bone, ${ }^{[239,240]}$ but also capable to act as 
framework for bone formation [241] with increased protein adsorption and enhanced osteoblast adhesion. ${ }^{[241-243]}$ Thus, combining polymers with calcium phosphates could mimic bone tissue physicochemically (i.e. composition and porous structure), mechanically and biologically (i.e. osteoconductivity). Composites appear promising, however their development implies the control of many parameters such as filler content and distribution, the chemistry and molecular weight of the polymer phase. These intrinsic properties of composites should be carefully balanced as they largely influence the characteristics of the final biomaterial.

The use of increasing amounts of inorganic filler, besides giving better biological characteristics, ${ }^{[241-243]}$ can improve the stiffness of the resulting composites. ${ }^{[243,}{ }^{332]}$ However, we observed that an excessive filler quantity, i.e. higher than $50 \%$ wt., may lead to brittle composites because the organic component is not sufficient to fully entrap the inorganic filler (see Chapter 3 of this thesis). Further to the content, a homogeneous distribution of the filler is crucial for the mechanical properties, particularly it favors uniform load transfer along the whole material. It is important to avoid filler aggregates because they are stress points where loads may concentrate provoking and supporting the formation of internal cracks, which later can lead to the breaking of the material. [333] In a previous study (see Chapter 3 of this thesis) we used a solvent-based method to prepare porous composites (porosity $>60 \% \mathrm{vv}$. with pore size 300-400 $\mu \mathrm{m}$ ). In that study we suspended nano-sized apatite particles in acetone and added poly(D,L-lactide), a polymer fully dissolvable in acetone. The resulting composites were not uniform and had aggregates (2 to $6 \mu \mathrm{m}$ size) of inorganic component (see Chapter 3 of this thesis) because during the solvent evaporation, the fuming of acetone may have shifted the apatite particles leading to their aggregation before the complete polymer hardening. Further, such solvent fumes may create nano- and/or micro-pores in the composite matrix (Figure 1).
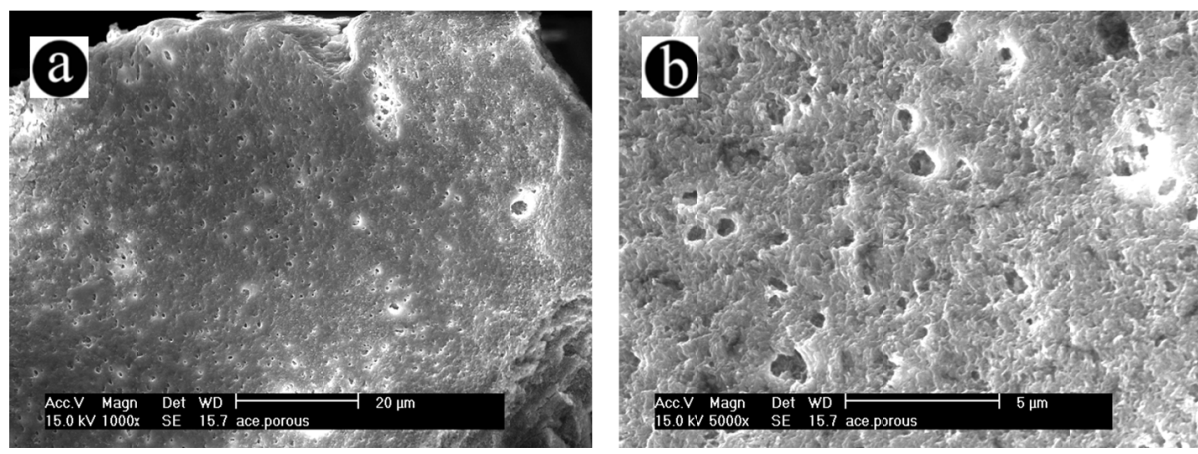

Figure 1. SEM picture of the surface of a composite prepared using solvent-way (i.e. acetone) showing the pores caused, most likely, by the solvent evaporation. Figure (b) is the higher magnification of (a). 
In an attempt to improve the quality of composites, in this study we used a dry preparation method, i.e. the co-rotatory twin-screw extrusion at high temperature. We chose this process because the co-rotatory screws system would homogeneously mix dry apatite powder into melted polymer. Further, a fast cooling of the resulting material would harden the polymer quickly entrapping apatite without letting it shift. Since extrusion is a high temperature processing method, it may cause thermal degradation of the polymer. The rotatory mixing in the presence of screws may also lead to 'mechanical' degradation of the polymer due to friction with the screws and apatite particles. In particular, we expect that increasing the content of apatite, higher friction will happen enhancing the degradation of the polymer phase. To test this hypothesis we prepared composites with various apatite contents and a high molecular weight copolymer. We then evaluated possible changes in the effect of extrusion on the chemistry, phase content, apatite distribution and polymer molecular weight of the composite.

Increasing the apatite phase content will enhance the stiffness of composites and decrease their damping characteristics. However, it would also render the composites more hydrophilic and therefore allow more fluid uptake. Thus, the higher content of apatite would absorb more fluids leading to a larger decrease in stiffness and improving the damping properties. At the same time, composites absorbing more fluids would trigger quicker hydrolysis of the polymer phase leading to faster degradation of the composites. To address this, we evaluated the dynamic mechanical properties of composites in dry and humid conditions and we also studied their degradation profile at body temperature for three months.

\subsection{Materials and Methods}

\subsubsection{Apatite preparation and characterization}

Nano-apatite powder was synthesized by adding $\left(\mathrm{NH}_{4}\right)_{2} \mathrm{HPO}_{4}$ (Fluka, Steinheim, Germany) aqueous solution ( $\mathrm{c}=63.1 \mathrm{~g} \mathrm{~L}^{-1}$ ) to $\mathrm{Ca}\left(\mathrm{NO}_{3}\right)_{2} \cdot 4 \mathrm{H}_{2} \mathrm{O}$ (Fluka) aqueous solution ( $\mathrm{c}=117.5 \mathrm{~g} \mathrm{~L}^{-1}$ ) at the controlled speed of $12.5 \mathrm{~mL} \mathrm{~min}^{-1}$ and $80 \pm 5^{\circ} \mathrm{C}$, with the reaction $\mathrm{pH}$ kept above 10 by using ammonia (Fluka). After precipitation, the resulting powder was aged overnight, washed with distilled water to remove ammonia, dehydrated in acetone (Fluka) and finally dried at $60 \pm 1^{\circ} \mathrm{C}$. Its chemistry was then investigated with X-ray diffractometry (XRD, MiniFlex II, Rigaku, Japan) using Cu K radiation $(\lambda=1.54056 \AA)$ operating at $30 \mathrm{kV}$ and $15 \mathrm{~mA}$. Spectra were collected at $0.083 \mathrm{deg} \mathrm{sec}^{-1}$ in the 29 range 5-90 deg. Following background subtraction (cubic spline method) and pattern smoothing (parabolic Savitzky-Golay filter set at 15 points), individual diffraction peaks were fitted $(R<7 \%)$ with pseudo-Voigt profiles (Lorentzian factor set to 0.65 ) and compared with international reference spectra for 
hydroxyapatite (i.e. JCPDS 9-432). Confocal Raman micro-spectroscopy (CR) was performed to analyse the surface chemistry using an in-home built machine according to van Manen. ${ }^{[334]}$ The $647.1 \mathrm{~nm}$ excitation light from a Krypton ion laser light source was focused onto the sample through a 40x air objective. Raman spectra were acquired in 0.5 seconds with a laser power of $35 \mathrm{~mW}$. For each sample, spectra (200-3600 $\mathrm{cm}^{-1}$ ) were taken at five randomly chosen spots. After pre-processing the spectra using routines written in LabVIEW (version 2009, National Instruments Nederland BV, Woerden, the Netherlands), the five spectra from each sample were averaged. The apatite particle size and morphology were characterized using transmission electron microscopy (TEM, Tecnai-200FEG, FEl Europe, Eindhoven, the Netherlands).

\subsubsection{Composites preparation and characterization}

The precipitated powder was extruded with $96 \% \mathrm{~mol}$. L-lactide $/ 4 \% \mathrm{~mol}$. D-lactide copolymer (declared inherent viscosity $5.67 \mathrm{dL} \mathrm{g}^{-1}$ with residual monomer $<0.2 \%$; kindly provided by Purac Biomaterials BV, Gorinchem, the Netherlands) to prepare 0/100\%wt., 25/75\%wt. and 50/50\%wt. apatite/polymer composites (M0, M25 and M50 respectively). The extrusion was done using a mini vertical conic twin-screw extruder (RD11-H-1009-025-4, DSM Research BV, Geleen, the Netherlands; top screw diameter: $10 \mathrm{~mm}$; bottom screw diameter: $4.15 \mathrm{~mm}$; screw thread: $8 \mathrm{~mm}$; screw length: $108 \mathrm{~mm}$ ) with temperature $205 \pm 1^{\circ} \mathrm{C}$, screws speed set at $100 \pm 1 \mathrm{rpm}$ for a mixing time of $5 \pm 0.5$ minutes. Granules $(0.5-1 \mathrm{~mm})$ were obtained by grinding the extruded green bodies at $14,000 \mathrm{rpm}$ for 15 seconds without particle size filter (ZM 100 grinder, Retsch, Haan, Germany) and then by hand sieving (sieves $0.5 \mathrm{~mm}$ and 1 $\mathrm{mm}$, Retsch). Bars $(50 \times 15 \times 2.5 \mathrm{~mm})$ were prepared by hot pressing $\left(150 \pm 1^{\circ} \mathrm{C}, 3 \pm 0.5\right.$ min, $250 \pm 10 \mathrm{kN})$ the granules into steel moulds. The surface of all samples was etched with $1 \mathrm{M}$ sodium hydroxide ( $\mathrm{NaOH}$, Merck, Darmstadt, Germany) at room temperature for $5 \pm 0.5$ minutes to obtain samples with similar surfaces. They were then sterilized with ethylene oxide (IsoTron Nederland BV, Ede, the Netherlands) and used for all the experiments described in this study. To evaluate the effect of extrusion and apatite content on the polymer, we measured its viscosity changes. Firstly we dissolved the samples overnight in chloroform $\left(\mathrm{CHCl}_{3}\right.$, Sigma-Aldrich, Steinhem, Germany) at low concentration ( $\left.c<5 \mathrm{mg} \mathrm{mL}^{-1}\right)$. The solutions were then vacuum filtered using glass filter (ROBU, Germany; Borosilicate 3.3. funnel capacity $50 \mathrm{~mL}$, glass filter with porosity \#5) with PTFE membrane filter (Toyo Roshi Kaisha, Advantec, Japan; $\varnothing 47 \mathrm{~mm}$, pore size $0.1 \mu \mathrm{m}$ ) to separate apatite from the polymer phase. Chloroform was then let to fully evaporate from the resulting solution to obtain the polymers. We then dissolved again the polymers in chloroform (Sigma-Aldrich) at 
a concentration of $0.1 \mathrm{~g} \mathrm{dL}^{-1}$ and determined the intrinsic viscosity $(<\eta>)$ using an Ubbelohde (ASTM) viscometer (OC, PSL-Rheotek, Burnham on Crouch, United Kingdom) at $25 \pm 0.1^{\circ} \mathrm{C}$. The intrinsic viscosity of the polymers was calculated with the Solomon-Ciută equation ${ }^{[356]}$ as follows:

$\eta_{\text {rel }}=t_{\text {pol }} / t_{\text {chlor }}$

$\eta_{\mathrm{sp}}=\eta_{\mathrm{rel}}-1$

$<\eta>=\left[\operatorname{sqr}\left(2 \cdot\left(\eta_{\mathrm{sp}}-\ln \left(\eta_{\mathrm{rel}}\right)\right)\right)\right] / \hat{c}$

where $t_{\text {pol }}$ and $t_{\text {chlor }}$ are the measured time for the solution of polymer and of pure chloroform to flow in the viscometer respectively, and $\hat{c}$ is the polymer concentration in chloroform. The effective content by weight (\%wt.) of apatite ( $\left.u_{\text {apatite }}\right)$ and polymer (U $u_{\text {polymer }}$ in the extruded composites was determined by burning the polymer out from the composites in a sinter oven (C19, Nabertherm, Lilienthal, Germany) at $900 \pm 5^{\circ} \mathrm{C}$ for two hours. We studied the surface chemistry of the composites (bars) with XRD and $\mathbf{C R}$ as described in $\S 4.2 .1$. Cross sections of the extruded materials were observed with scanning electron microscopy (Philips XL 30 ESEM-FEG, Philips, Eindhoven, the Netherlands) in the backscattered mode (BSEM) to evaluate the distribution of apatite particles in the entire material. After making ultra-thin sections of the three materials (thickness $\sim 50 \mathrm{~nm}$ ) using a diamond knife (ultra AFM knife, Diatome AG, Biel, Switzerland), the distribution of apatite in the materials was observed also using transmission electron microscopy (TEM, Tecnai-200FEG, FEI Europe, Eindhoven, the Netherlands). Dynamic contact angle measurements were performed to evaluate the surface hydrophilicity and drop spreading rate on the surface of the composites. At room temperature a drop of $0.6 \mu$ l of distilled water was placed on the surface of the bars. Pictures were taken with a digital camera (PowerShot SX200 IS, Canon Nederland NV, Amstelveen, the Netherlands) immediately after the drop placement and then every 5 seconds for 9 minutes. Measurements of the contact angle from the pictures were done with the software Image $(\mathrm{v} 1.43 \mathrm{u}, \mathrm{NIH}, \mathrm{USA})$ using the freely distributed plugin Drop-Shape Analysis working on the snake-based approach. ${ }^{[335]}$

\subsubsection{In vitro degradation of the composites}

A saline physiological solution (SPS) was prepared by dissolving sodium chloride ( $\mathrm{NaCl}$, Merck, $\mathrm{c}=8 \mathrm{~g} \mathrm{~L}^{-1}$ ) and 4-(2-hydroxyethyl)-1-iperazineethane-sulfonic acid (HEPES, Sigma-Aldrich, $\mathrm{c}=11.92 \mathrm{~g} \mathrm{~L}^{-1}$ ) in distilled water. The $\mathrm{pH}$ of the solution was adjusted to 7.3 with $2 \mathrm{M} \mathrm{NaOH}$ (Merck) at $37^{\circ} \mathrm{C}$. Sterile granules of each composite $(0.5 \pm 0.01 \mathrm{~g})$ were carefully weighed before use $\left(\mathrm{m}_{0}\right)$ and soaked in $200 \mathrm{~mL}$ SPS (in triplicate) at $37 \pm 1^{\circ} \mathrm{C}$ for 3 months under a 3-week refreshing regime. Every three weeks, the $\mathrm{pH}$ of the degrading solution was recorded with a pH-meter (Orion $4 \mathrm{Star}$, 
Thermo Scientific, USA). With the solution removed at every refreshing time point, the concentration (in $\mu \mathrm{M}$ ) of calcium and phosphate ions were measured using appropriate biochemical kits (QuantiChrom ${ }^{\mathrm{TM}}$ Calcium assay kit, BioAssay Systems, USA; PhosphoWorks ${ }^{\mathrm{TM}}$ Colorimetric Phosphate Assay kit Blue Color, Bioquestlnc, USA) with the help of a spectrophotometer (AnthosZenyth 3100, AnthosLabtec Instruments $\mathrm{GmbH}$, Salzburg, Austria) and absorbance filter of $620 \mathrm{~nm}$ for both assays. After 12 weeks the granules were removed from the degrading media, the excess SPS was wiped away and they were carefully weighed ( $\left.m_{\text {wet }}\right)$. Afterwards, they were vacuum-dried at $37 \pm 1^{\circ} \mathrm{C}$ until their weight was stable and then weighed again ( $m_{\text {dry }}$ ). The mass loss and fluid uptake of the composites was determined as follows:

mass loss $=100 \cdot\left(m_{0}-m_{\text {dry }}\right) / m_{0}$

fluid uptake $=100 \cdot\left(m_{\text {wet }}-m_{\text {dry }}\right) / m_{\text {dry }}$

Part of the degraded samples was heated at $900^{\circ} \mathrm{C}$ to burn the polymer phase out and determine the final effective apatite and polymer percentage contents (in \%wt., $p_{a p}$ and $p_{p o l}$ respectively). We then calculated the phase content changes due to degradation as follows:

$\bar{u}_{\text {apatite }}=100 \cdot \mathrm{m}_{\mathrm{dry}} \cdot \mathrm{p}_{\mathrm{ap}}$

$\overline{\mathrm{u}}_{\text {polymer }}=100 \cdot \mathrm{m}_{\mathrm{dry}} \cdot \mathrm{p}_{\mathrm{pol}}$

apatite phase change $=100 \cdot\left(\bar{u}_{\text {apatite }}-u_{\text {apatite }}\right) / u_{\text {apatite }}$

polymer phase change $=100 \cdot\left(\bar{u}_{\text {polymer }}-u_{\text {polymer }}\right) / u_{\text {polymer }}$

where $u_{\text {apatite }}$ and $u_{\text {polymer }}$ are the initial phase contents (in grams) of apatite and polymer as determined in $\S 4.2 .2$.

Following the procedure described in $\$ 4.2 .2$, the remnant part of the degraded samples was used to evaluate the degradation of the polymer phase by measuring its post-degradation intrinsic viscosity after 12 weeks.

\subsubsection{Dynamic mechanical characterization}

Bars were analysed with a dynamic mechanical analyzer (DMA 2980, TA Instruments, New Castle, DE, USA) in three-point bending, over a sweep of physiological frequencies $(1-10 \mathrm{~Hz}, 0.3 \mathrm{~Hz} \mathrm{~min}-1)$ at $37 \pm 0.1^{\circ} \mathrm{C}$ with static force $0.53 \pm 0.01 \mathrm{~N}$ and dynamic displacement $10 \pm 0.01 \mu \mathrm{m}$. The samples were kept at $37 \pm 0.01^{\circ} \mathrm{C}$ for $15 \pm 1$ minutes to stabilize the material prior the measurements. The tests were done separately on dry samples and moist materials after soaking in distilled water at $37 \pm 1^{\circ} \mathrm{C}$ for one week. The data measured were storage modulus and loss tangent. 


\subsection{Results}

\subsubsection{Characterization of apatite}

XRD showed that the synthesized powder is a calcium phosphate apatite (Figure 2a) with similarities to hydroxyapatite reference (i.e. JCPDS 9-432). Using CR (Figure 2b, Table 2) we observed that the synthesized apatite had all the characteristic vibrational bands for a calcium phosphate apatite. Needle-like apatite particles measuring 300$400 \mathrm{~nm}$ in length and $20-40 \mathrm{~nm}$ in width were seen with TEM (Figure 2c).

\subsubsection{Characterization of composites}

XRD and CR patterns showed that, when the filler content increased, there were corresponding increases in the intensity of the apatite peaks while the characteristic peaks of the copolymer decreased (Figure 2a,b; Table 2). These observations were supported by the effective apatite contents measured with burn test (Table 1).
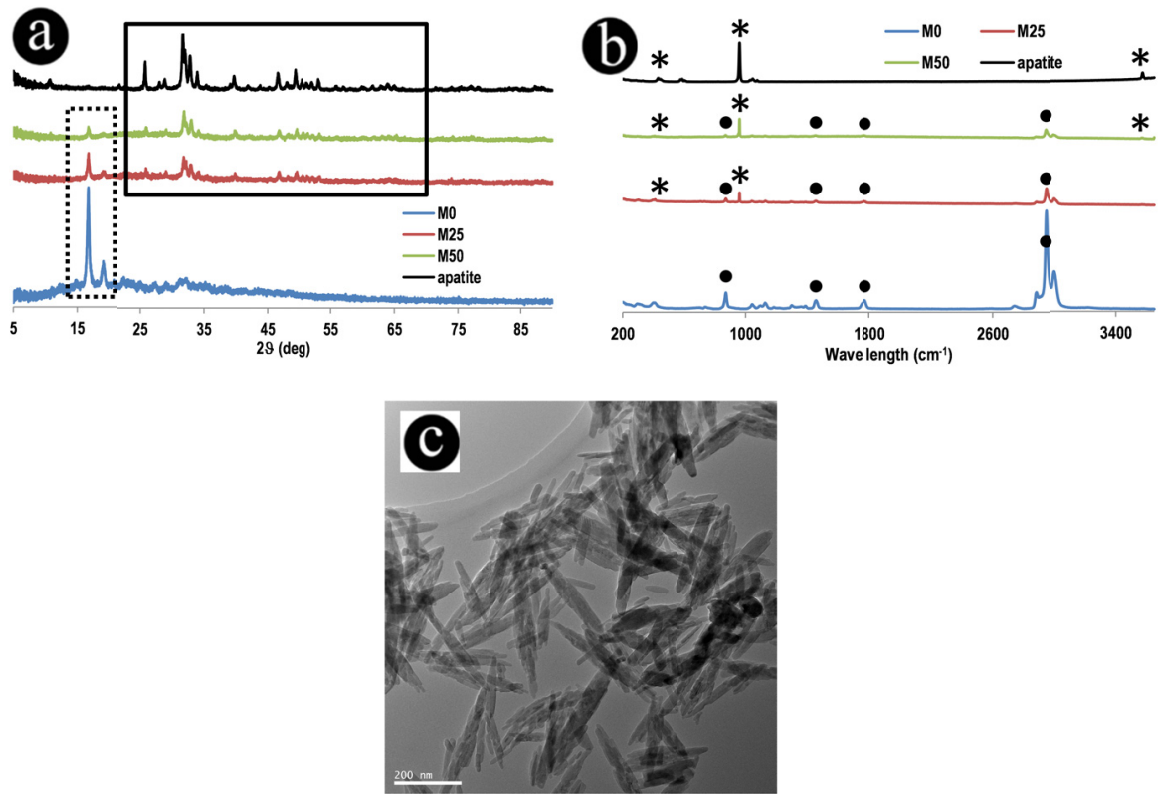

Figure 2. (a) XRD and (b) CR spectra for unsintered apatite, M0, M25 and M50. The rectangles in (a) represent XRD peaks for apatite (continuous line) and copolymer (dotted line) respectively. Stars and filled circles in (b) represent apatite and copolymer CR peaks respectively. (c) TEM picture of the synthesized unsintered apatite.

These results demonstrated that we introduced into the copolymer amounts of apatite close to those expected (i.e. 0, 25 and 50\%wt. apatite; M0, M25 and M50 respectively). Images taken with TEM and BSEM showed that apatite particles were uniformly distributed in the polymer matrix, with no agglomerates or voids (Figure 3 ). 
Measurements with Ubbelohde viscometer showed significant post-extrusion decreases in intrinsic viscosity for the copolymer, which was correlated with the apatite content. In fact, in higher apatite containing materials there was a larger viscosity decrease (Table 3). Dynamic contact angle measurements (Figure 4) indicated a significant increase in surface hydrophilicity with the increase of apatite content (ANOVA, $p=10^{-8}$, comparison of initial values). The sharp and larger decrease in contact angle of M50 over time indicated that it absorbed water quicker than M25. The contact angle of M0 kept stable indicating no or little water absorption.

\subsubsection{In vitro degradation}

As expected, there was larger fluid uptake when more apatite was present (Table 4), which led to polymer hydrolysis as indicated by intrinsic viscosity changes. Unexpectedly, larger fluid uptake corresponded to smaller decrease in intrinsic viscosity (Table 2). In filler-containing composites, i.e. M25 and M50, apatite dissolution and/or release of whole apatite particles occurred as shown by the increasing calcium and phosphate ion concentration in SPS over time.

As expected, M25 released significantly fewer ions as compared to M50 due to its lower apatite content (Figure 5; Table 4). The phase content of apatite (and polymer) remained relatively stable, varying within $\pm 1-3 \%$ compared to their starting counterparts (Table 1).
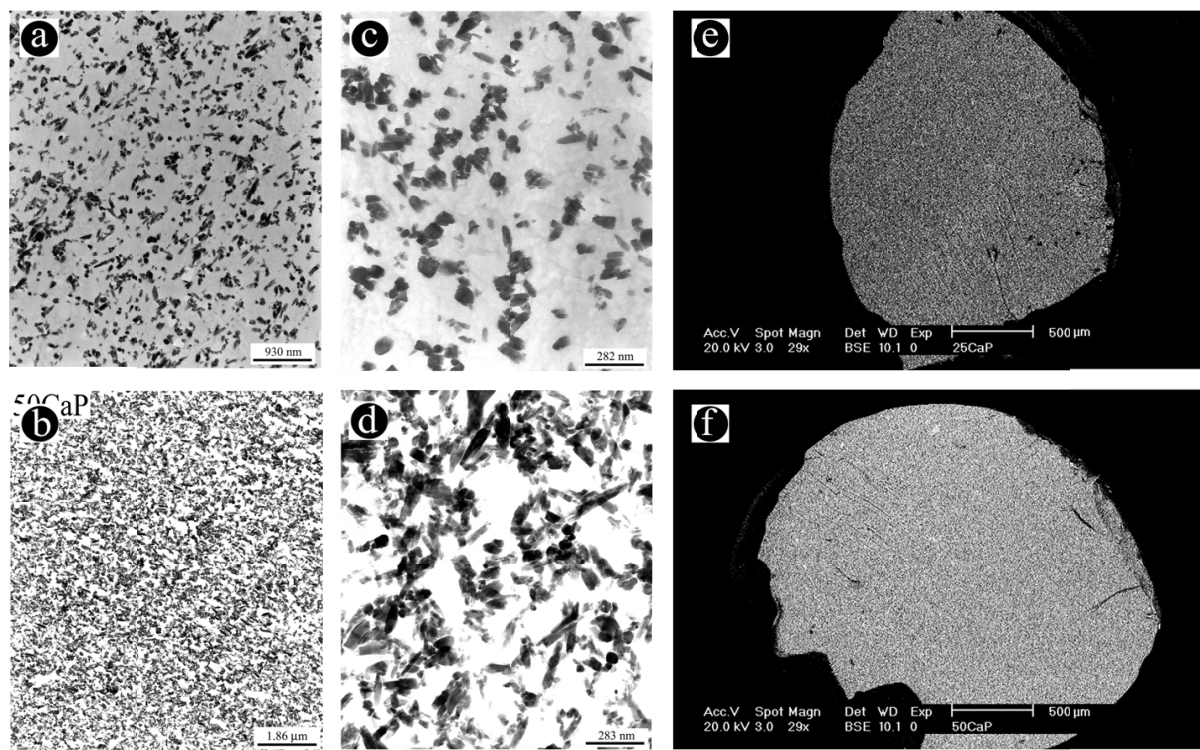

Figure 3. TEM images of M25 at (a) low and (c) high magnification. TEM images of M50 at (b) low and (d) high magnification. BSEM images of cross-sections of (e) M25 and (f) M50 taken under the same conditions of electron beam voltage, working distance, contrast and brightness. Uniform distribution of apatite particles in both composites is observed. Due to the lower content of apatite, M25 appears darker than M50 (see as reference BSEM images in Chapter 3). 
However, by considering the two phases separately, we observed that M25 had the largest loss in apatite phase, while M50 showed the largest loss in polymer phase (Table 1). Consistently with the above reported data, larger mass loss was seen in higher apatite containing materials (Table 4).

Table 1. Burn test results on the composites as prepared and after 12-week in vitro degradation. Results are reported in terms of apatite and polymer phase contents [\%wt.]. Changes in phase content were calculated as explained in $\S 4.2 .3$. Statistical comparison is expressed in terms of $p$-values where ANOVA was used to compare the apatite content among the three materials in the same condition, while $t$-test was used to compare the changes of apatite content due to the degradation.

\begin{tabular}{llll|l}
\hline & $\begin{array}{l}\text { As prepared } \\
\text { apatite [\%wt.] } \\
\text { polymer [\%wt.] }\end{array}$ & $\begin{array}{l}\text { 12-week in vitro degraded } \\
\text { apatite [\%wt.] } \\
\text { polymer [\%wt.] }\end{array}$ & $\begin{array}{l}\text { p, t-test } \\
\text { apatite as prep.-degr. } \\
\text { polymer as prep.-degr. }\end{array}$ & $\begin{array}{l}\text { Phase loss } \\
\text { apatite [\%] } \\
\text { polymer [\%] }\end{array}$ \\
\hline \multirow{2}{*}{ M0 } & $0.1 \pm 0.2$ & $0.1 \pm 0.1$ & 1 (no) & $0 \pm 0$ \\
& $99.9 \pm 0.2$ & $99.9 \pm 0.1$ & $1(\mathrm{no})$ & $0 \pm 0$ \\
\hline \multirow{2}{*}{ M25 } & $23.7 \pm 0.2$ & $22.6 \pm 0.3$ & 0.045 & $-8.0 \pm 1.6$ \\
& $76.3 \pm 0.2$ & $77.4 \pm 0.3$ & 0.04 & $-2.7 \pm 0.5$ \\
\hline \multirow{2}{*}{ M50 } & $48.5 \pm 0.5$ & $52.2 \pm 0.3$ & 0.035 & $-3.9 \pm 0.3$ \\
& $51.5 \pm 0.5$ & $47.8 \pm 0.3$ & 0.04 & \\
\hline p, ANOVA & & & & \\
M0-M25 & $<10^{-4}$ & $<10^{-4}$ & & \\
M0-M50 & $<10^{-5}$ & $<10^{-5}$ & & \\
M25-M50 & $<10^{-3}$ & $<10^{-3}$ & & \\
\hline
\end{tabular}

\subsubsection{Dynamic mechanical analysis.}

Mechanical testing has been performed in three-point bending conditions over a frequency sweep covering the normal physiological frequencies from 1 to $10 \mathrm{~Hz}$ simulating the walk to fast running. The analysis temperature was set to the physiological one (i.e. $37 \pm 0.1^{\circ} \mathrm{C}$ ), and the tests have been run with both dry and wet samples. As expected, the recorded storage modulus in dry conditions significantly increased with the apatite content (Figure 6). Unexpectedly, the loss tangent of M50 was significantly higher than M25 and M0, which indeed had similar damping characteristics. This fact must be correlated with the degrading effects that the extrusion process had on the polymer phase of the composites. When the apatite containing samples were moistened, their mechanical properties changed abruptly. Moisture had little or no effect on the storage modulus of $\mathrm{M} 0$ while, as expected, it decreased the modulus of M25 and M50, with the latter having the largest decrease. At the same time, the loss tangent increased with the largest change occurring in the composite containing more apatite. When the materials were dry, the modulus kept stable over the frequency sweep, while it had decreasing trend in moistened M50 but not in samples with lower apatite contents. As regards the loss tangent, in general it has decreasing trends with increasing frequency. 


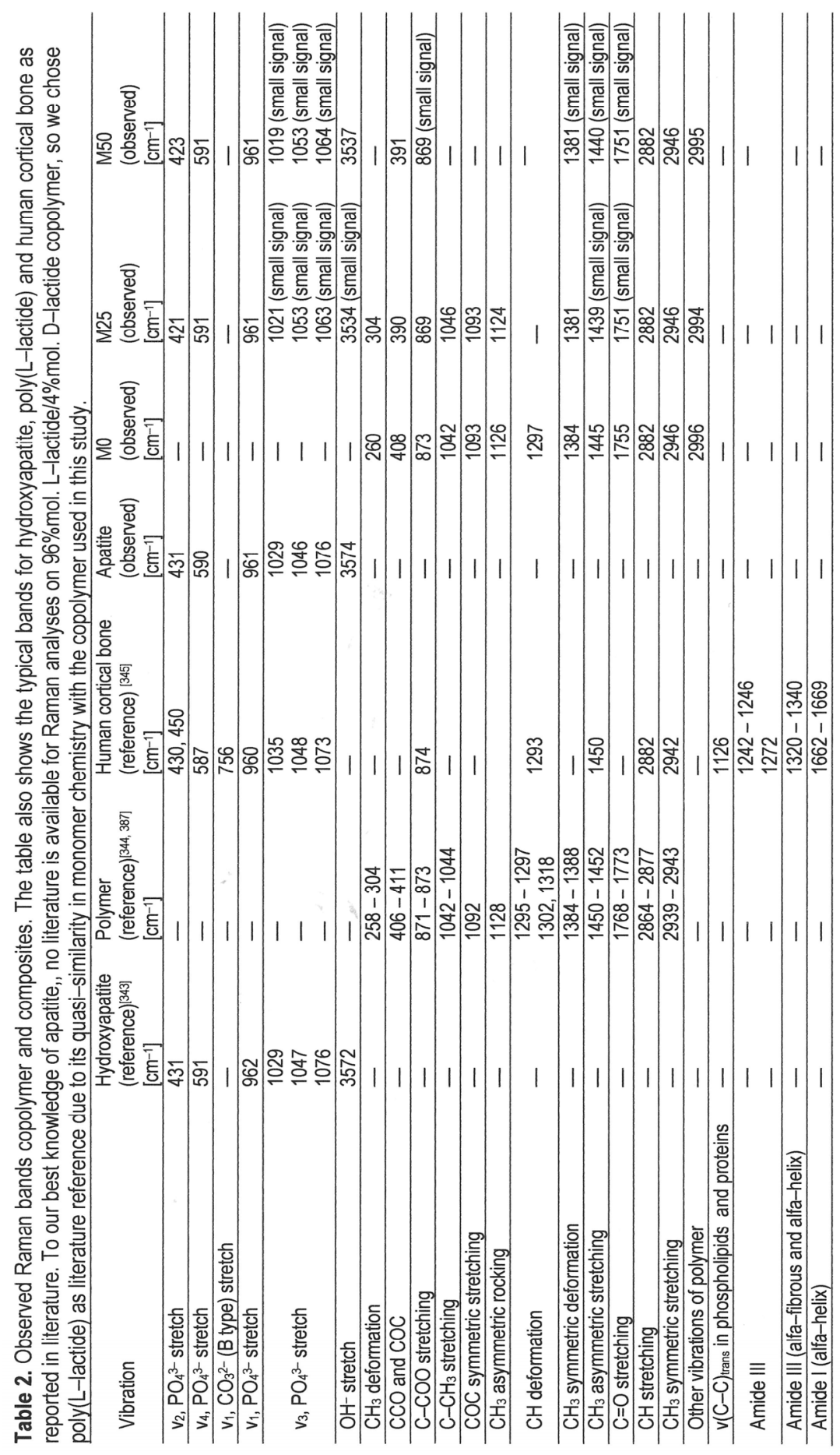

80 
Table 3. Ubbelohde measurements of intrinsic viscosity $<\eta>$ for the copolymer as supplied, after extrusion without (M0) and with apatite particles (i.e. M25 and M50), and after 12-week degradation in vitro. Statistical comparison is expressed in terms of $p$-values where ANOVA was used to compare the viscosity among the three materials in the same condition, while t-test was used to compare the changes of viscosity due to the degradation. In the table are indicated also the percentage variations of the viscosity after degradation (as compared to intrinsic viscosity of the materials 'as prepared').

\begin{tabular}{|c|c|c|c|c|}
\hline & $\begin{array}{l}\text { Copolymer } \\
\text { as supplied } \\
<\eta>\left[\mathrm{dL} \mathrm{g}^{-1}\right]\end{array}$ & $\begin{array}{l}\text { Material as } \\
\text { prepared } \\
<\eta>\left[\mathrm{dL} \mathrm{g}^{-1}\right]\end{array}$ & $\begin{array}{l}\text { 12-week } \\
\text { degradation in vitro } \\
<\eta>\left[\mathrm{dL} \mathrm{g}^{-1}\right]\end{array}$ & $\begin{array}{l}\text { p, t-test } \\
\text { as prep. - degr. }\end{array}$ \\
\hline M0 & \multirow{3}{*}{$6.17 \pm 0.01$} & $3.05 \pm 0.01$ & $1.69 \pm 0.03(-44 \%)$ & $<0.01$ \\
\hline $\mathrm{M} 25$ & & $1.13 \pm 0.01$ & $0.88 \pm 0.02(-22 \%)$ & 0.015 \\
\hline M50 & & $0.60 \pm 0.01$ & $0.49 \pm 0.02(-18 \%)$ & 0.03 \\
\hline \multicolumn{5}{|l|}{$p$, ANOVA } \\
\hline M0-M25 & & $10^{-3}$ & $<0.01$ & \\
\hline M0-M50 & $\mathrm{n} / \mathrm{a}$ & $10^{-4}$ & $10^{-3}$ & \\
\hline M25-M50 & & $<0.015$ & $<0.02$ & \\
\hline
\end{tabular}

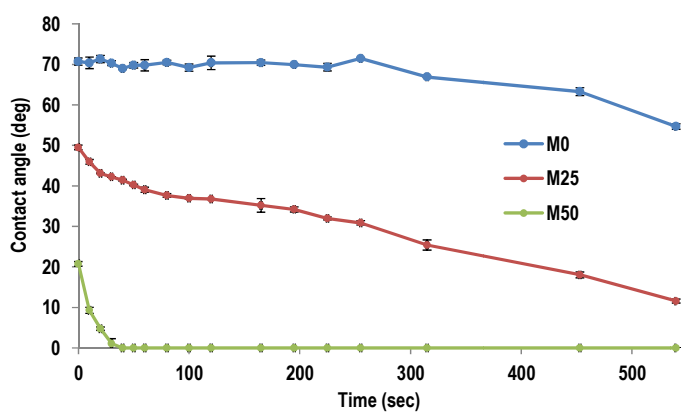

Figure 4. Dynamic contact angle measurements indicated that materials containing more apatite had more hydrophilic surfaces. Over time the angle decreased for all the three materials, with a sharp and quick decrease for M50 and a milder decrease for M25.
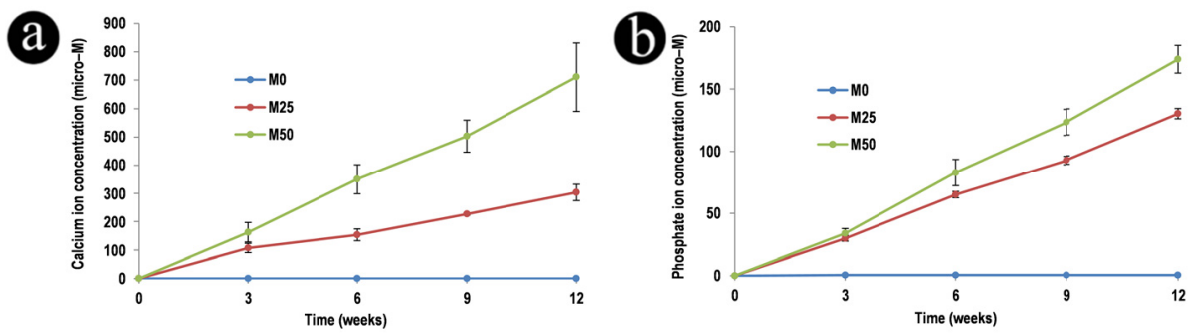

Figure 5. Changes in (a) calcium and (c) phosphate ion concentration when the materials were placed in SPS for 12 weeks. 
Table 4. Calcium and phosphate cumulative ion release into $200 \mathrm{~mL}$ of SPS and mass loss after 12 weeks in vitro degradation in SPS. Statistical comparison is expressed in terms of $p$-values in the text.

\begin{tabular}{lllll}
\hline & $\begin{array}{l}\text { Calcium release } \\
{[\mu \mathrm{M}]}\end{array}$ & $\begin{array}{l}\text { Phosphate release } \\
{[\mu \mathrm{M}]}\end{array}$ & $\begin{array}{l}\text { Mass loss } \\
{[\%]}\end{array}$ & $\begin{array}{l}\text { Fluid uptake } \\
{[\%]}\end{array}$ \\
\hline M0 & $0 \pm 0$ & $0 \pm 0$ & $0.05 \pm 0.03$ & $0.7 \pm 0.06$ \\
\hline M25 & $303 \pm 28$ & $130 \pm 4$ & $3.9 \pm 0.02$ & $4.7 \pm 0.4$ \\
\hline M50 & $710 \pm 120$ & $173 \pm 11$ & $10.8 \pm 0.1$ & $7.5 \pm 0.2$ \\
\hline $\begin{array}{l}\text { p, ANOVA } \\
\text { (for all combinations) }\end{array}$ & $<10^{-3}$ & $<0.02$ & $<10^{-3}$ & $<0.025$ \\
\hline
\end{tabular}

\subsection{Discussion}

As expected, extruding the copolymer alone led its thermal degradation with consequent worsening of the polymer properties, in particular its intrinsic viscosity halved (Table 3). This result is consistent with literature, where the same copolymer was extruded at high temperature $\left(>200^{\circ} \mathrm{C}\right)$ and its intrinsic viscosity was found to decrease 34 to $43 \%$ depending on the starting viscosity. ${ }^{[336]}$ When the polymer was processed with apatite particles, we observed that, besides thermal degradation, there was also a 'mechanical' degradation caused by frictional effects between polymer and apatite particles. This led to abrupt decrease of intrinsic viscosity with the increase of apatite content in the composites (Table 3). As mentioned earlier, the extrusion process firstly provoked thermal degradation where the polymer chains were broken. Helped by this, higher contents of nano-sized apatite particles may have further provoked the rupture of the polymer chains during the extrusion enhancing polymer degradation. Thus, the polymer in M50 had lower intrinsic viscosity than $\mathrm{M} 0$ and $\mathrm{M} 25$ (Table 3).

However, extrusion successfully led to composites with highly uniform distribution of nano-sized apatite particles in the polymer matrix (Figure 3). This homogeneity led to composite materials that could keep stable mechanical properties when the stresses were applied with increasing physiological frequencies (as indicated by their modulus in dry conditions, Figure 6a). The lack of inhomogeneities, such as apatite agglomerates or voids, may have allowed a uniform distribution of the stresses over the composite avoiding the generation of stress concentration points that could cause cracks. ${ }^{[333]}$ The presence of apatite particles increased the stiffness of the materials because they may have 'bridged' the polymer chains, rendering them less prone to shift with each other during the mechanical stressing. So, increasing amounts of apatite particles could block more polymer chains further hindering their movement with a consequent increase in storage modulus (Figure 6a). In dry conditions we observed higher damping characteristics for the stiffer material, i.e. M50, as indicated by higher values of loss tangent (Figure 6b). This observation clashes with the fact that M50 has high storage modulus. This may be explained with the fact that 
the polymer in M50 has significantly lower viscosity than M25 and M0. In general it is expected that polymers with shorter and looser chains, i.e. having lower viscosity, are more flexible and thus more prone to dissipate energy during the stress. Therefore, in spite of its higher stiffness, M50 had larger damping properties by virtue of the lower viscosity of its polymer phase.

Increasing amounts of apatite particles increased the hydrophilicity (Figure 4) and the capacity of composites to uptake fluids (Table 4). This fact had large implications on the mechanical properties since, in presence of water, the stiffness of the materials containing apatite, i.e. M25 and M50, largely decreased. On the contrary, the most hydrophobic material (i.e. M0) kept its initial stiffness. Water may have seeped more into the materials with higher apatite content, rendering the apatite/polymer contacts less stable and adding more freedom in molecular movements decreasing in this way the storage modulus. Thus, besides having the lowest viscosity polymer phase, M50 also absorbed more water and thus its mechanical stiffness decreased most. Water also had a plasticizer effect rendering the polymer phase more viscoelastic, as shown by an increase of the tangent for all materials (Figure 6d). Interestingly, the increasing damping properties occurred largely for materials with increasing apatite contents since, besides having lower polymer viscosity, they had larger ability to uptake water.
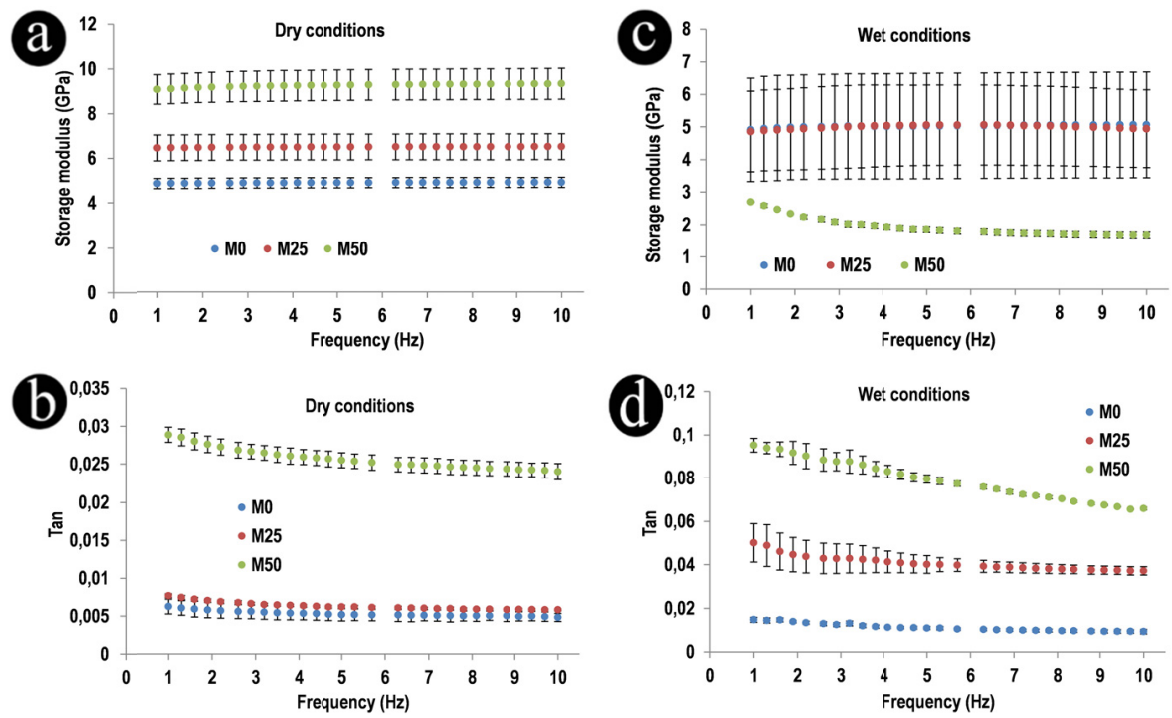

Figure 6. Storage modulus of the materials in (a) dry and (c) wet conditions. Loss tangent in (b) absence and (d) presence of water. 
Extrapolating the data recorded at $1 \mathrm{~Hz}$ in dry conditions, it may be concluded that M50 had storage modulus and loss tangent close to those measured, in three-points bending at $1 \mathrm{~Hz}$, on dry human cortical bone extracted from femora[338] (Figure 7), while other literature data show loss tangent for human bone in physiological loading frequency range (i.e. $0.1-10 \mathrm{~Hz}$ ) ranging between 0.01 and $0.02,{ }^{[339,340]}$ values lower than those measured by Yamashita, ${ }^{[338]}$ and this discrepancy in tangent may depend on the analytical methods. In moist conditions, the modulus of the composite was lower than cortical bone while the tangent was higher (Figure 7), ${ }^{[338]}$ thus further improvements in the elastic and viscoelastic properties are needed for load-bearing applications in vivo. To strengthen the composite and avoid that water can largely affect its mechanical properties, it would be useful to chemically bind the calcium phosphate particles to the polymeric chains. Several groups have already shown the possibility to bind calcium phosphate particles to polymer chains through the use of coupling agents such as isocyanate groups ${ }^{[341,342]}$ or phosphonic acid. [332] In this way, apatite would play a larger role in controlling the dependence of mechanical properties from the loading frequency and the moisture.

Besides influencing on the mechanical properties, apatite particles also affected the degrading trends of the materials. As mentioned earlier, the higher apatite content led to larger fluid uptake when placed for three months in saline solution (Table 4), and polymer hydrolysis could be triggered in all the samples. However, due to the different starting polymer intrinsic viscosity, the polymer hydrolysis trends were different.

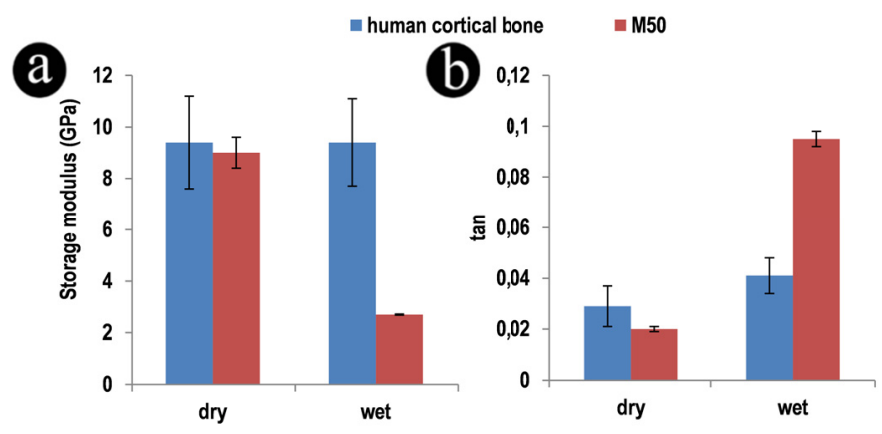

Figure 7. Comparison of (a) storage modulus and (b) loss tangent (measured at $1 \mathrm{~Hz}, 37^{\circ} \mathrm{C}$ in threepoint bending, dry and wet conditions) between M50 and human cortical bone. ${ }^{[338]}$

In particular, there was sharper decrease of the viscosity in materials with higher starting intrinsic viscosity and vice versa (Table 3). These results are in line with literature, where $96 \% \mathrm{~mol}$. L-lactide $/ 4 \% \mathrm{~mol}$. D-lactide copolymer was degraded in phosphate buffered solution for six months and larger decrease in molecular weight 
was observed for copolymers having increasing initial molecular weight.[336] Further, the presence of aqueous fluid also dissolved apatite particles and, consistently, there was an increasing release of ions with the apatite content in the composites (Figure 5). The dissolution of apatite may have acted as buffering agent slowing down the polymer autocatalysis. In M0 hydrolysis could have been catalyzed by the acidic degradation residuals of the polymer. ${ }^{[349]}$ On the contrary, in M25 and M50 the release of calcium and phosphate (Figure 5) may have buffered the acid polymer residuals hindering the polymer autocatalysis. Consequently, the intrinsic viscosity changes were smaller in M25 and M50 (Table 3). In terms of effective phase loss, M0 did not have polymer loss, while M50 had the largest polymer phase loss (Table 1). As observed earlier, M50 contained the polymer with the lowest starting intrinsic viscosity, which may have favored the loss of more polymer residuals from the composite. On the contrary, M25 showed the largest apatite phase loss (about -8\%), which might be explained with its larger polymer content (i.e. $~ 75 \%$ wt.) that may have rendered the local $\mathrm{pH}$ more acidic favoring the dissolution and/or release of whole apatite particles. It should be mentioned that, however, M50 had the larger apatite content (i.e. $\sim 50 \%$ wt.) than M25 and this is why the ion concentrations recorded in SPS were higher for M50. The phase loss results are consistent with the observed increasing mass loss of the materials with apatite content (Table 4). Considering all the results together, the whole degradation of the composite (i.e. mass loss) is accelerated by the increase of apatite content. Clashing with the results normally found in literature, in this case the degradation was accelerated by the apatite content. This might be explained with the fact that most of the composites presented in literature were prepared using solvent-based methods (by mixing, casting or sonication/freezing procedures), ${ }^{[239,240,242,243]}$ or co-precipitation. ${ }^{235,409]}$ It is worth to remind that we have shown in Chapter 3 that solvent-based methods do not degrade the polymer phase, independently from the calcium phosphate phase content. We expect similar results also for other non-thermal methods used for the preparation of composite materials. In this study, the polymer was degraded during the extrusion, and the extent of this degradation was dependent on the apatite content. In particular, the intrinsic viscosity of the copolymer lowered with the increase of the added apatite amount. The differences in intrinsic viscosity amongst the three materials were, in this case, sufficiently large to justify the observed degradation trends. We cannot now affirm whether and how the composites degradation influenced on their mechanical properties. However, it is worthy to observe that the composite released ions, which may be important factors in bone regeneration. It has been speculated that ion release not only enhances the bioactivity of calcium phosphate-based materials, ${ }^{[241,}$ 243] but also the proliferation and differentiation of cells into osteogenic 


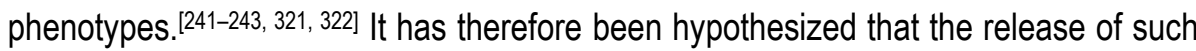
ions might contribute in triggering and enhancing bone formation. However, the role of ions on the (stem) cell osteogenic differentiation onto biomaterials still needs to be fully demonstrated.

It is interesting that, in literature, it was also shown that the formation of increasing amounts of L-lactide monomer was caused by the extrusion of $96 \% \mathrm{~mol}$. Llactide/4\%mol. D-lactide copolymer with increasing initial molecular weight. It was postulated that the monomer formation was provoked during the thermal degradation. ${ }^{[336]}$ Interestingly, those copolymers having higher post-extrusion amounts of L-lactide monomer also had higher hydrolytic degradation rate. [336] Therefore, it may be expected that, being the initial molecular weight of the copolymer used in this study high, significant amounts of $L$-lactide monomer could be generated after extrusion of the composites. Similarly to the monomer content, the processing method (i.e. history) may have influenced also on the polymer crystallinity affecting on the final degrading and mechanical properties. ${ }^{[387]}$ It is expected that during high temperature extrusion all polymers lose their crystallinity and become amorphous. It is known that, after extrusion, the polymers need to be slowly cooled in order to let their chains re-arrange into a structure similar to the initial one. ${ }^{[387]}$ Since we quickly cooled the extruded composite, we expect that the crystallinity level is lower than the initial one. However, the manufacturing methods and conditions (i.e. temperature and cooling step) used to make the three materials were the same, thus we do not expect much differences in monomer content or crystallinity between the three materials unless the 'frictional' degradation with apatite particles had any role. To verify any possible effect of apatite content on the post-extrusion monomer content and crystallinity changes, measurements on the post-extrusion monomer content and crystallinity are necessary in future studies. Mechanical performances may be also influenced my monomer content and crystallinity, particularly in moistened conditions.

\subsection{Conclusion}

The data herein presented demonstrated that, despite its drawbacks, extrusion can be used to produce highly homogeneous composite materials with controllable phase content. However, apatite, during extrusion, generates friction enhancing the polymer degradation: the higher the filler content and the stronger the decrease in molecular weight with consequences on the mechanical and degradation behaviors of the final composites. The filler content also directs the hydrophilicity, with dramatic effects. For example, we observed that the dynamic elasticity of dry materials increases with the apatite content, but it abruptly decreases when the samples were moistened and this decrease was directly correlated with apatite content. On the other side, the 
viscoelastic characteristics mainly depend on the polymer phase, where lower molecular weight gave better damping characteristics, which increase in presence of moisture. Further, the presence of apatite accelerates the degradation of the whole composite (i.e. mass loss) due to its effect on the polymer, but slowers down the polymer phase hydrolysis as its ions may act as buffers. Other factors, such as the post-extrusion monomer content and extrusion, are not expected in this study, but cannot be now completely excluded. 



\section{CHAPTER 5}

Effects of alkali surface treatment on the properties of nano-apatite and polymer composites 



\subsection{Introduction}

Inspired by the nano-composite structure of bone, in the last decade scientists have striven to develop biomaterials having as close characteristics as possible to those of bone tissue. From a material perspective, bone is a bi-phasic material mainly comprising a collagenous matrix reinforced by nano-particles of carbonated apatite.[21, 22] Several approaches have been described to replicate the physicochemical structure of bone in vitro. For instance the process of collagen mineralization has been mimicked to get composite materials chemically and hierarchically similar to bone tissue.[213] Other proposed methods were producing macro-porous blocks comprising silk fibers or polyester matrices and calcium phosphates to mimic the composite macro-structure of bone.[214, 239, 240] The addition of high content of hydroxyapatite particulate (up to $50 \%$ wt.) did not only improve the mechanical properties of the materials but also rendered them osteoconductive, i.e. able to act as framework for bone formation, ${ }^{[241]}$ with increased protein adsorption and enhanced osteoblast adhesion.[241-243] Composites of polymers and calcium phosphate could mimic bone tissue physicochemically (i.e. composition), physically (i.e. porous structure) and biologically with respect to the osteoconductive property. As potential bone grafting materials, composites may be further improved with respect to their osteoinductive properties and allow heterotopic bone formation without added osteogenic cells or bone growth factors (see Chapter 3 ).

It has been proposed that certain surface features of biomaterials, in particular the topographical characteristics such as shape, size and disorder degree of pattern units (e.g. pits, grooves or pillars), influence the cell behave. For instance, by controlling the depth and width of micro-grooved surfaces, $\mathrm{C} 2 \mathrm{C} 12$ murine myoblast cell alignment was tuned leading to myotube formation. ${ }^{[358]}$ Groove-like features not only regulated the behavior of muscle cells but also of osteoblasts, whose alignment and mineral deposition improved when they were cultured on grooves with nano-sized dimensions. ${ }^{[359]}$ Regular patterns of micro- and nano-pits and pillars positively affected fibroblast cell attachment, spreading and migration by offering various combinations of adhesion sites for fibroblastic filopodia. ${ }^{[152,360]}$ On the contrary, improved adhesion and proliferation of human mesenchymal stem cells were observed on smooth surfaces, ${ }^{[191,361]}$ while osteoblasts privileged adhering onto rough ones. ${ }^{[362]}$ The topography has also shown to drive cellular differentiation into specific phenotypes, for example human mesenchymal stem cells cultured on 200 to $350 \mathrm{~nm}$ wide nano-gratings preferentially originated neurogenic and myogenic cells. $\left.{ }^{191,} 361\right]$ Not only the shape and size of ordered topographies were reported to affect cell fate, but it was also seen that increased surface roughness, i.e. a surface with large distribution of height irregularities, led to diminished osteoblastic proliferation and 
increased osteogenic differentiation.[363] Furthermore, it was seen that increased disorder degree of surface pattern units tuned human mesenchymal stem cell differentiation into bone cells in absence of osteogenic factors. ${ }^{195]}$ Summarizing, the surface topography and roughness can have significant influence on the cellular performance that ultimately affects the interactions between biomaterials and the biological surroundings. From the above review, it appears that stem cells preferentially differentiate into osteogenic phenotypes when adhering onto topographically disordered (i.e. with a not-well defined pattern) and rough surface textures.

It is believed that when materials with specific surface textures are implanted, in addition to the effects of the surrounding interstitial matrix, ${ }^{[364]}$ (stem) cells are sensitive to such surface topographies. Thus, by properly designing the surface, osteogenic differentiation may be triggered allowing bone formation even in heterotopic sites. ${ }^{[86]}$ As mentioned earlier, there is increasing interest to develop instructive biomaterials with suitable mechanical properties for the repair and regeneration of defects in load-bearing bone. Calcium phosphate-based composites gained interest as they already have proven biocompatibility, osteoconductivity and have tunable mechanical properties. However, controlling and improving the osteoinductive property of such biomaterials is still under investigation. Based on the above review, in this study we hypothesized that increasing the surface roughness of composites would better support osteogenic differentiation of stem cells and thus would render the material osteoinductive.

In Chapter 4 we evaluated composites containing nano-sized apatite and high molecular weight $96 \% \mathrm{~mol}$. L-lactide/4\%mol. D-lactide copolymer in different content ratios, and we observed that its composites with 50\%wt. nano-apatite were degradable with promising mechanical properties. We now, in this study, want to test and tune its in vitro and in vivo biological responses by means of surface roughness. We prepared such composite and then alkali treated its surface to finally obtain three samples having different roughness levels. After evaluating the in vitro degradation and surface mineralization of the three materials, we studied their ability to adsorb proteins. Afterwards we cultured human bone marrow stromal stem cells on such materials to evaluate the effect of the surface characteristics on cell osteogenic differentiation. Finally, we implanted these materials intramuscularly in dogs to evaluate whether the different surface features resulted in osteoinduction. 


\subsection{Materials and Methods}

\subsubsection{Apatite preparation and characterization}

Nano-apatite powder was synthesized by adding $\left(\mathrm{NH}_{4}\right)_{2} \mathrm{HPO}_{4}$ (Fluka, Steinheim, Germany) aqueous solution ( $\mathrm{c}=63.1 \mathrm{~g} \mathrm{~L}^{-1}$ ) to $\mathrm{Ca}\left(\mathrm{NO}_{3}\right)_{2} \cdot 4 \mathrm{H}_{2} \mathrm{O}$ (Fluka) aqueous solution ( $\mathrm{c}=117.5 \mathrm{~g} \mathrm{~L}^{-1}$ ) at the controlled speed of $12.5 \mathrm{~mL} \mathrm{~min}^{-1}$ and $80 \pm 5^{\circ} \mathrm{C}$ and keeping the reaction $\mathrm{pH}$ above 10 by dropwise adding ammonia (Fluka). After precipitation, the resulting powder was aged overnight, washed with distilled water to remove ammonia, dehydrated in acetone (Fluka) and finally dried at $60 \pm 1^{\circ} \mathrm{C}$. Its chemistry was then investigated with $X$-ray diffractometry (XRD, MiniFlex II, Rigaku, Japan) using Cu K radiation ( $\lambda=1.54056 \AA$ ) operating at $30 \mathrm{kV}$ and $15 \mathrm{~mA}$. Spectra were collected at $0.083 \mathrm{deg} \mathrm{sec}^{-1}$ in the $2 \vartheta$ range 5-90 deg. Unit cell parameters of the powder were determined from XRD data using the software Jade (v6.5.26, Materials Data Inc., Livermore, CA, USA). Following background subtraction (cubic spline method) and pattern smoothing (parabolic Savitzky-Golay filter set at 15 points), individual diffraction peaks were fitted $(R<7 \%)$ with pseudo-Voigt profiles (Lorentzian factor set to 0.65 ) and the unit cell parameters were estimated after a cell refinement procedure for hexagonal lattice P63/m. Confocal Raman microspectroscopy (CR) was performed to analyse the surface chemistry using an in-home built machine according to van Manen. ${ }^{[334]}$ The $647.1 \mathrm{~nm}$ excitation light from a Krypton ion laser light source was focused onto the sample through a 40x air objective. Raman spectra were acquired in 0.5 seconds with a laser power of $35 \mathrm{~mW}$. For each sample, spectra $\left(200-3600 \mathrm{~cm}^{-1}\right)$ were taken at five randomly chosen spots. After preprocessing the spectra using routines written in LabVIEW (version 2009, NI, the Netherlands), the five spectra from each sample were averaged. The apatite particle size and morphology were characterized using transmission electron microscopy (TEM, Tecnai-200 FEG, FEI Europe, Eindhoven, the Netherlands). Using a fast Fourier transform algorithm on TEM signals (FFT-HRTEM), the interplanar spacing of apatite (i.e. the $d$-value) was determined.

\subsubsection{Composites preparation}

The precipitated powder was extruded with $96 \% \mathrm{~mol}$. L-lactide $/ 4 \% \mathrm{~mol}$. D-lactide copolymer (declared inherent viscosity $5.67 \mathrm{dL} \mathrm{g}^{-1}$ with residual monomer $<0.2 \%$; Purac Biomaterials, Gorinchem, the Netherlands) to prepare $50 / 50 \%$ wt. apatite/polymer composite. The extrusion was done using a mini vertical conic twinscrew extruder (RD11-H-1009-025-4, DSM Research BV, Geleen, the Netherlands; top screw diameter: $10 \mathrm{~mm}$; bottom screw diameter: $4.15 \mathrm{~mm}$; screw thread: $8 \mathrm{~mm}$; screw length: $108 \mathrm{~mm}$ ) with temperature $205 \pm 1^{\circ} \mathrm{C}$, screws speed set at $100 \pm 1 \mathrm{rpm}$ for a mixing time of $5 \pm 0.5$ minutes. Granules $(0.5-1 \mathrm{~mm})$ were obtained by grinding 
the extruded green bodies at 14,000 rpm for 15 seconds without particle size filter (ZM 100 grinder, Retsch, Haan, Germany) and then by hand sieving (sieves $0.5 \mathrm{~mm}$ and $1 \mathrm{~mm}$, Retsch). Discs $(\varnothing 8 \times 0.4 \mathrm{~mm})$ were prepared by hot pressing $\left(150 \pm 1^{\circ} \mathrm{C}\right.$, $3 \pm 0.5 \mathrm{~min}, 250 \pm 10 \mathrm{kN}$ ) the granules into steel moulds. The surface of discs was polished with polish machine (LaboPol-5, Struers, Ballerup, Denmark) using waterproof silicon-carbide sand paper (\#4000, Struers) for $20 \pm 1 \mathrm{sec}$ at $300 \mathrm{rpm}$ to make the surface of discs as much similar as possible with each other. Granules and discs were then surface etched with 0,1 or $2 \mathrm{M}$ sodium hydroxide $(\mathrm{NaOH}$, Merck, Darmstadt, Germany) at room temperature for $5 \pm 0.5$ minutes to obtain three composites having different surface characteristics (M0, M1 and M2 respectively). Granules and discs were then sterilized with ethylene oxide (IsoTron Nederland BV, Ede, the Netherlands) and used for all the experiments described in this study.

\subsubsection{Composites characterization}

\subsubsection{Physicochemical}

The chemistry of polymer and composites was evaluated using XRD and CR as explained earlier using discs of the materials. The effective content by weight (\%wt.) of apatite and polymer in the extruded composites was determined by burning the polymer out from the composites in a sinter oven (C19, Nabertherm, Lilienthal, Germany) at $900 \pm 5^{\circ} \mathrm{C}$ for two hours. To evaluate the effect of extrusion and surface treatment on the polymer, we firstly separated the filler from the polymer phase by dissolving the samples overnight in chloroform (Sigma-Aldrich, Steinhem, Germany) at low concentration ( $c<5 \mathrm{mg} \mathrm{mL}^{-1}$ ). The solutions were then vacuum filtered using glass filter (ROBU, Germany; Borosilicate 3.3. funnel capacity $50 \mathrm{~mL}$, glass filter with porosity \#5) with PTFE membrane filter (Toyo Roshi Kaisha, Advantec, Japan; $\varnothing 47$ $\mathrm{mm}$, pore size $0.1 \mu \mathrm{m}$ ) to separate apatite from the polymer. Chloroform was let to fully evaporate from the resulting solution to obtain the polymers. We then dissolved again the three polymers in chloroform (Sigma-Aldrich) at $c=0.1 \mathrm{~g} \mathrm{dL}^{-1}$ and determined the intrinsic viscosity $\langle\eta\rangle$ with an Ubbelohde (ASTM) viscometer (OC, PSL-Rheotek, Burnham on Crouch, United Kingdom) at $25 \pm 0.1^{\circ} \mathrm{C}$. The intrinsic viscosity of the polymers was calculated according to Solomon-Ciută[356] as follows:

$\eta_{\text {rel }}=t_{\text {pol }} / t_{\text {chlor }}$

$\eta_{\mathrm{sp}}=\eta_{\mathrm{rel}}-1$

$<\eta>=\left[\operatorname{sqrt}\left(2 \cdot\left(\eta_{\mathrm{sp}}-\ln \left(\eta_{\mathrm{rel}}\right)\right)\right)\right] / \hat{c}$

where $t_{\mathrm{pol}}$ and $t_{\mathrm{chlor}}$ are the measured time for the solution of polymer and pure chloroform to flow in the viscometer respectively, and $\hat{c}$ is the polymer concentration in chloroform. Scanning electron microscopy in secondary electron modality (SEM) was performed on loose granules to evaluate their surface topography and apatite 
exposure. Part of the granules of the materials were also embedded in epoxy resin (Sigma-Aldrich), sectioned to have cross-sections of the granules and observed in backscattered modality (BSEM) to evaluate their bulk and the effect of alkali treatment at their surface. To evaluate the extent of apatite exposure caused by the etching, at least twenty random granules were considered in BSEM images. Using the software Image ( $\mathrm{v} 1.43 \mathrm{u}, \mathrm{NIH}, \mathrm{USA})$, the average thickness of these apatite layers was measured with the help of the scale bar. As the sectioning plane was random respect to the granules, it is expected that the measureable characteristics of the layers (i.e. their thickness) had a normal distribution of probability and thus, statistically speaking, the method here proposed might be used to evaluate the materials.

\subsubsection{Surface properties}

The surface characteristics of the three materials (in the form of discs) were evaluated with an atomic force microscope (AFM, Bioscope Catalyst AFM, Bruker AXS, Wormer, the Netherlands) in tapping mode using an ESP cantilever (total tip height from 10 to $15 \mu \mathrm{m}$, probe tip radius $12 \mathrm{~nm}$, full type cone radius $25^{\circ}$, spring constant $0.2 \mathrm{~N} \mathrm{~m}^{-1}$ ). The images were taken with a scan frequency of $1 \mathrm{~Hz}$ performing dual scans over an area of $50 \times 50 \mu \mathrm{m}$ and analysed with SPIP software (v5.1.11, Image Metrology A/S, Hørsholm, Denmark) after correcting the plane and removing background/measurement noise using proper digital filters. In this way, twodimensional and three-dimensional height maps were obtained, which allowed us evaluating the surface topographical features. Besides visual results, measurements were taken on average roughness $(\mathrm{Ra})$, root mean square $(\mathrm{Rq})$ and average ten largest top-bottom heights (Rz). The distribution of the measured heights compared to a zero-plane (i.e. a flat plane positioned at middle height of the surface profile of the sample) was also obtained. Static water contact angle measurements were performed to evaluate the surface hydrophilicity on the surface of the composites. At room temperature a drop of $0.6 \mu \mathrm{l}$ of distilled water was placed on the surface of the discs. Pictures were taken with a digital camera (PowerShot SX200 IS, Canon Nederland NV, Amstelveen, the Netherlands) immediately after the drop placement. Measurements of the contact angle from the pictures were done with the software Image ( $1.43 \mathrm{u}, \mathrm{NIH}, \mathrm{USA})$ using the freely distributed plugin Drop-Shape Analysis working on the snake-based approach. ${ }^{[335]}$

\subsubsection{Remarks}

It should be mentioned that AFM and hydrophilicity measurements have been done on discs instead of granules (for experiment design needs). Thus the numerical 
measures cannot be directly applied to the granules. However, as alkali surface treatment has been the same for discs and granules, the roughness and hydrophilicity trends seen on discs are expected also on the granules.

\subsubsection{In vitro degradation}

A saline physiological solution (SPS) was prepared by dissolving sodium chloride ( $\mathrm{NaCl}$, Merck) (8 $\left.\mathrm{g} \mathrm{L}^{-1}\right)$ and 4-(2-hydroxyethyl)-1-iperazineethane-sulfonic acid (HEPES) (Sigma-Aldrich) (11.92 $\left.\mathrm{g} \mathrm{L}^{-1}\right)$ in distilled water. The $\mathrm{pH}$ of the solution was adjusted to 7.3 with $2 \mathrm{M} \mathrm{NaOH}$ (Merck) at $37^{\circ} \mathrm{C}$. Sterile granules of each composite $(0.5 \pm 0.01 \mathrm{~g})$ were carefully weighed before use $\left(\mathrm{m}_{0}\right)$ and soaked in $200 \mathrm{~mL}$ SPS (in triplicate) at $37 \pm 1^{\circ} \mathrm{C}$ for three months under a 3-week refreshing regime. Every three weeks, the $\mathrm{pH}$ of the degrading solution was recorded with a pH-meter (Orion 4 Star, Thermo Scientific, USA). With the solution removed at every refreshing time point, the concentration (in $\mu \mathrm{M}$ ) of calcium and phosphate ions were measured using appropriate biochemical kits (QuantiChrom ${ }^{\mathrm{TM}}$ Calcium assay kit, BioAssay Systems, USA; PhosphoWorks ${ }^{\mathrm{TM}}$ Colorimetric Phosphate Assay kit Blue Color, Bioquestlnc, USA) with the help of a spectrophotometer (AnthosZenyth 3100, AnthosLabtec Instruments $\mathrm{GmbH}$, Salzburg, Austria) and absorbance filter of $620 \mathrm{~nm}$ for both assays. After 12 weeks the granules were removed from the degrading media, the excess SPS was wiped away and they were carefully weighed ( $\left.m_{\text {wet }}\right)$. Afterwards, they were vacuum-dried at $37 \pm 1^{\circ} \mathrm{C}$ until their weight was stable and then weighed again $\left(m_{\text {dry }}\right)$. The mass loss and fluid uptake of the composites were determined as follows:

mass loss $=100 \cdot\left(m_{0}-m_{\text {dry }}\right) / m_{0}$

fluid uptake $=100 \cdot\left(m_{\text {wet }}-m_{\text {dry }}\right) / m_{\text {dry }}$

Part of the degraded samples was heated at $900^{\circ} \mathrm{C}$ to burn the polymer phase out and determine the final effective apatite and polymer percentage contents. Following the procedure described in $\$ 5.2 .3$, the remnant part of the degraded samples was used to evaluate the degradation of the polymer phase by measuring its post-degradation intrinsic viscosity after 12 weeks.

\subsubsection{In vitro surface mineralisation}

Surface mineralisation was studied in two different solutions, i.e. basic simulated body fluid (SBF), and simulated body fluid containing 10\% (in volume) foetal bovine serum (SBF/FBS). Dipping the samples in SBF will give an indication of their surface mineralising potential, while SBF/FBS is a solution simulating the 'real' situation in the body where proteins are present. This second experiment will indicate whether the proteins influence on the surface mineralising potential of the materials. Simulated 
body fluid (SBF) was prepared according to Kokubo[247] by dissolving reagent grade chemicals (Merck) in distilled water strictly in the following order: $\mathrm{NaCl}, \mathrm{NaHCO}_{3}, \mathrm{KCl}$, $\mathrm{K}_{2} \mathrm{HPO}_{4} \cdot 3 \mathrm{H}_{2} \mathrm{O}, \mathrm{MgCl}_{2} \cdot 6 \mathrm{H}_{2} \mathrm{O}, \mathrm{CaCl}_{2}$ (calcium ion standard solution $0.1 \mathrm{M}$, Metrohm, Herisau, Switzerland) and $\mathrm{Na}_{2} \mathrm{SO}_{4}$. The fluid was then buffered to $\mathrm{pH} 7.4$ at $36.5^{\circ} \mathrm{C}$ using Tris $\left(\left(\mathrm{CH}_{2} \mathrm{OH}\right)_{3} \mathrm{CNH}_{3}\right)$ and $1 \mathrm{M} \mathrm{HCl}$. The final solution had an ion concentration (in mM) as follows: $\mathrm{Na}^{+}, 142 ; \mathrm{K}^{+}, 5 ; \mathrm{Mg}^{2+}, 1.5 ; \mathrm{Ca}^{2+}, 2.5 ; \mathrm{Cl}^{-}, 147.8 ;\left(\mathrm{HCO}_{3}\right)^{-}, 4.2$; $\left(\mathrm{HPO}_{4}\right)^{2-}, 1 ;\left(\mathrm{SO}_{4}\right)^{2-}, 0.5$. Sodium azide was added to SBF (in the final quantity of $0.0025 \%$ volume) to prevent bacterial contamination. SBF/FBS solution was prepared by adding ten parts in volume of foetal bovine serum (FBS, Invitrogen, UK) to ninety parts of SBF. Since SBF, by definition, is serum without proteins, the ion concentration in the final SBF/FBS solution is the same of normal SBF. Granules of the composite $(0.1 \mathrm{~g})$ were soaked in $40 \mathrm{~mL}$ SBF or SBF/FBS (in quintuple) at $37 \pm 1^{\circ} \mathrm{C}$ for seven days. Afterwards, they were removed from the solutions, carefully rinsed with distilled water and dried. Part of the samples was gold-sputtered and observed with SEM in secondary electron modality. Following the method explained earlier, other granules were embedded in epoxy resin (Sigma-Aldrich), sectioned and observed at BSEM for quantification (in thickness) of mineralized apatite layers using the software ImageJ (v1.43u, NIH, USA).

\subsubsection{Serum protein adsorption}

Serum protein adsorption was studied under two different conditions to better understand the biological performance of the materials. In particular, we evaluated their adsorption from 10\% basic FBS in water and from simulated body fluid containing $10 \%$ (in volume) foetal bovine serum (i.e. SBF/FBS). Dipping the samples (in the form of granules) in FBS solution will give an indication of their protein adsorption potential, while testing in SBF/FBS will indicate whether surface mineralization has any effect on protein adsorption. Sterile granules $(0.1 \mathrm{~g})$ of the composites were placed (in quintuple) in $40 \mathrm{~mL}$ of $10 \%$ FBS (Invitrogen) or SBF/FBS (i.e. described in $\$ 5.2 .4$ ) containing $0.0025 \%$ v. sodium azide to prevent bacterial contamination. They were incubated at $37 \pm 0.5^{\circ} \mathrm{C}$ and $5 \% \mathrm{CO}_{2}$ for one week. Serum proteins adsorbed from both solutions were measured (in $\mu \mathrm{g}$ per $\mathrm{cc}$ ) after seven days using micro BCA assay kit (Pierce Biotechnology Inc., Rockford, IL, USA) and spectrophotometer (Anthos) with absorbance filter of $595 \mathrm{~nm}$. Standard calibration serum protein curves were built after determining the concentration of proteins in pure serum (i.e. $33.78 \pm 0.64 \mathrm{mg} \mathrm{mL}^{-1}$ ). 


\subsection{7. rhBMP-2 adsorption from enriched culture medium}

A solution with final rhBMP-2 concentration of $500 \mathrm{ng} \mathrm{mL}^{-1}$ was prepared by diluting recombinant human bone morphogenetic protein-2 (rhBMP-2, Reborne, Shanghai, P.R. China) in Dulbecco's modified Eagle's medium (D-MEM, Invitrogen) containing 10\% FBS (Invitrogen), $100 \mathrm{IU} \mathrm{mL} \mathrm{m}^{-1}$ penicillin (Invitrogen) and $100 \mu \mathrm{g} \mathrm{mL}^{-1}$ streptomycin (Invitrogen). Sterile discs of the three composites were then soaked in such solution ( $3 \mathrm{~mL}$ per disc, $\mathrm{n}=5$ per material) at $37 \pm 0.1^{\circ} \mathrm{C}$ for 24 hours. After washing three times with phosphate buffered solution (PBS, Sigma-Aldrich) the discs were frozen at $-80^{\circ} \mathrm{C}$ for at least 12 hours and then $0.5 \mathrm{~mL}$ of $1 \%$ triton $\mathrm{X}-100$ (Sigma-Aldrich) was put onto each sample and kept at $4^{\circ} \mathrm{C}$ for at least 12 hours. Thereafter the samples were ultrasonically shaken for five minutes and, finally, rhBMP-2 concentration in the supernatant was measured using BMP-2 Elisa kit (Quantikine, R\&D Systems, Minneapolis, USA). The fluorescent signal was measured with a spectrophotometer at $450 \mathrm{~nm}$. The rhBMP-2 adsorption (expressed in ng per disc) was estimated through a standard calibration rhBMP-2 curve.

\subsection{8. hBMSCs cell culture}

We chose to perform cell studies on discs to avoid cell seeding and nutritional inhomogeneities, which are usually associated to three-dimensional cultures such as on (porous) granules. Human bone marrow stromal stem cells (hBMSCs, Lonza, Köln, Germany) at the passage P5 $\rightarrow \mathrm{P} 6$ were expanded in an expansion medium (Table 1) with a seeding concentration of $1 \times 10^{3} \mathrm{cells}^{-2}$ on a T300 culture flask under a 4-day medium refreshment regime until $75 \%$ confluence. The expansion process occurred at $37 \pm 0.1^{\circ} \mathrm{C}$ in a $5 \% \mathrm{CO}_{2}$ atmosphere in incubator (NAPCO 5410 , Themo-Electron Corp., Winchester, USA). Once expanded, the cells were harvested with $0.25 \%$ trypsin solution, suspended in osteogenic medium (Table 1 ) and counted with Burker-Türk hemocytometer. They were seeded on composites discs $(\varnothing 8 \times 0.4$ $\mathrm{mm}$ ) at a concentration of $2.5 \times 10^{3}$ cells per disc. The samples were then incubated at $37 \pm 0.1^{\circ} \mathrm{C}$ in a $5 \% \mathrm{CO}_{2}$ atmosphere for two weeks (refreshing medium twice a week). To evaluate cell proliferation, quantification of total DNA was performed after 1, 4, 7 and 14 days using CyQuant dye kit (Invitrogen). Cells were rinsed three times with PBS (Sigma-Aldrich) and digested in $0.3 \mathrm{~mL}$ lysis buffer $(0.5 \%$ triton $\mathrm{X}-100$, SigmaAldrich, in PBS) in each culture well. The resulting mixtures were then ultrasonically treated for 10 minutes and centrifuged at 4,000 rpm for 5 minutes. A $50 \mu \mathrm{L}$ cell lysate was mixed with $50 \mu \mathrm{l} 20 \mathrm{X}$-Cyquant lysis buffer diluted 20 times with $180 \mathrm{mM} \mathrm{NaCl}$ and $1 \mathrm{mM}$ EDTA solution with 1.35 kunitz RNAase addition $(0.2 \% \mathrm{v} / \mathrm{v}$.). After one hour incubation at room temperature in dark, $100 \mu \mathrm{L}$ GR reagent diluted 20 times with the same diluted 20X-Cyquant lysis buffer was added and incubated at room 
temperature in dark for 20 minutes. A standard curve of known concentration of DNA was generated concurrently and used to determine sample concentrations. To evaluate the DNA content, the samples were excited with $480 \mathrm{~nm}$ wavelength and fluorescence emission was read at $520 \mathrm{~nm}$ with a spectrophotometer (AnthosLabtec Instruments $\mathrm{GmbH}$ ). To evaluate cell differentiation, alkaline phosphatase (ALP) activity was measured at the time points 1, 4, 7 and 14 using the same lysate than for DNA assay. A $50 \mu \mathrm{L}$ cell lysate was mixed with $50 \mu \mathrm{L} p$-nitrophenylphosphate ( $\mathrm{p}-$ NPP) (Sigma-Aldrich) in $1 \mathrm{M}$ diethanolamine buffer containing $1 \mathrm{mM} \mathrm{MgCl} 2(\mathrm{pH} 9.8)$ and incubated at $37^{\circ} \mathrm{C}$ for 15 minutes. The reaction was stopped by the addition of 50 $\mu \mathrm{L}$ of $0.1 \mathrm{~N} \mathrm{NaOH}$. A standard curve of known concentration of $p$-nitrophenol (Sigma) was generated concurrently and used to determine sample concentrations. Enzyme activity was quantified by absorbance measurements at $405 \mathrm{~nm}$ (AnthosLabtec Instruments $\mathrm{GmbH}$ ). All experiments were conducted in quintuplicate.

Table 1. Composition of the two culture mediums used. All the components were purchased from Invitrogen.

\begin{tabular}{llll}
\hline Component & & Expansion & Osteogenic \\
\hline $\begin{array}{l}\text { Minimum essential medium ( } \alpha-M E M) \\
\text { with ribonucleosides but without ascorbic acid }\end{array}$ & {$[\% \mathrm{vv}]$.} & 90 & 90 \\
\hline Foetal bovine serum (FBS) & {$[\% \mathrm{vv}]$.} & 10 & 10 \\
\hline L-glutamine & {$[\mathrm{mM}]$} & 2 & 2 \\
\hline L-ascorbic acid 2-phosphate (ASAP) & {$[\mathrm{mM}]$} & 0.2 & 0.2 \\
\hline Penicillin & {$[\mathrm{lU} \mathrm{mL}-1]$} & 100 & 100 \\
\hline Streptomycin & {$\left[\mu \mathrm{g} \mathrm{mL}^{-1}\right]$} & 100 & 100 \\
\hline Basic fibroblast growth factor (bFGF) & {$[\mathrm{ng} \mathrm{mL}-1]$} & 1 & 0 \\
\hline Dexamethason (DEX) & {$[\mathrm{nM}]$} & 0 & 10 \\
\hline
\end{tabular}

\subsubsection{In vivo tissue response}

With the permission of the local animal care committee (Animal Center, Sichuan University, Chengdu, China; protocol \#P11029), granules of the three composites (0.5 g) were implanted in the paraspinal muscles of six skeletally mature mongrel dogs (male, 1-4 years old, weight 10-15 kg) for 12 weeks to evaluate the tissue reaction and the osteoinductive property of the composites. The surgical procedure was performed under general anaesthesia (pentobarbital sodium, Organon, the Netherlands; $30 \mathrm{mg} \mathrm{kg}^{-1}$ body weight) and sterile conditions. The back of the dogs was shaved and cleaned with iodine. A longitudinal incision was made and the paraspinal muscle was exposed by blunt separation. Longitudinal muscle incisions were subsequently made with a scalpel and separate muscle pouches were created by blunt separation. The granules were then placed in the pouches and the wound was closed in layers using silk sutures. After surgery, the animals received intramuscular injections of penicillin for three consecutive days to prevent infection. 
Twelve weeks after implantation, the animals were sacrificed and the samples were harvested with surrounding tissues and fixed in $4 \%$ buffered formaldehyde solution $(\mathrm{pH}=7.4)$ at $4^{\circ} \mathrm{C}$ for one week. After rinsing with phosphate buffer saline (PBS, Invitrogen), the samples were trimmed from surrounding soft tissues and split in two parts: about $3 / 4$ for histological observations and $1 / 4$ for degradation analysis. The parts for histology were dehydrated in a series of ethanol solutions $(70 \%, 80 \%, 90 \%, 95 \%$ and $100 \% \times 2$ ) and embedded in methyl metacrylate (MMA, LTI Nederland, the Netherlands). Non-decalcified histological sections (10-20 $\mu \mathrm{m}$ thick) were made using a diamond saw microtome (Leica SP1600, Leica Microsystems, Germany). Sections for light microscopy observations were stained with $1 \%$ methylene blue (Sigma-Aldrich) and $0.3 \%$ basic fuchsin (Sigma-Aldrich) solutions after etching with acidic ethanol (Merck). The sections were observed with a light microscope (Nikon Eclipse E200, Japan) to analyse the tissue reaction and bone formation. BSEM was also performed on the sectioned samples to further evaluate the materials in terms of degradation, mineralized surface (including quantitative analysis as described earlier) and bone formation. Before use, the other parts of the explants were rinsed in 1\% triton $\mathrm{X}-100$ (Sigma-Aldrich) in phosphate buffered saline to completely remove the tissues from the granules. Afterwards the granules were washed several times in distilled water and vacuum-dried at $37 \pm 1^{\circ} \mathrm{C}$ for at least 48 hours. Part of these granules was heated at $900^{\circ} \mathrm{C}$ to burn the polymer phase out and determine the final effective apatite and polymer percentage contents. Following the procedure described in $\$ 5.2 .3$, the remnant part of the samples was used to evaluate the degradation of the polymer phase by measuring its post-implant intrinsic viscosity after 12 weeks in vivo.

\subsubsection{Statistical analysis}

Two tail t-test (for populations with different variance) and post-hoc Tamhane ANOVA test were used to evaluate differences in the results. The choice between the two tests relied on the size of the compared data. If the data populations to be compared were two, $t$-test was use. If populations were more, ANOVA was used. A $\mathrm{p}$-value lower than 0.05 was considered as significant difference in both statistical tests. The analyses were performed using Origin software (v8.0773, OriginPro, Northampton, MA, USA).

\subsection{Results}

\subsubsection{Characterization of apatite}

XRD showed that the synthesized powder is a calcium phosphate apatite (Figure 1a). Calculations on the XRD data, based on the diffraction angle and the corresponding reflection plane $(h k l)$, led to the estimation of unit cell parameters for apatite as 
$a=9.41 \pm 0.03 \AA$ and $c=6.88 \pm 0.02 \AA$, which are similar to those reported in literature for human cortical bone apatite $(a=9.38 \AA, c=6.87 \AA)$ on the same reflection planes. ${ }^{[315]}$ Using CR (Figure 1b) we observed that the spectrum of the synthesized apatite contained all the characteristic vibrational bands for a calcium phosphate apatite, and chemical similarity with bone mineral was seen (see also Table 3 in Chapter 4). Needle-like apatite particles having 200-350 nm length and 20-30 nm width were seen with TEM (Figure 1c), and such size is similar to that of needle-like apatite observed in human cortical bone.[23] Interplanar spacing (i.e. the $d$-value) in the synthesized apatite has been estimated with FFT-HRTEM as $7.85 \pm 0.39 \AA$ (Figure 1d) that is close to the typical values recorded for synthetic hydroxyapatite. ${ }^{[365]}$

\subsubsection{Characterization of composites}

\subsubsection{Physicochemical (granules and discs)}

The composite was prepared by extruding high molecular weight $96 \% \mathrm{~mol}$. Llactide $/ 4 \%$ mol. D-lactide copolymer with calcium phosphate apatite particles. Measurements with Ubbelohde viscometer showed significant post-extrusion decreases in intrinsic viscosity for the copolymer contained in the composites. However, the final three composites had comparable polymer phase intrinsic viscosity (Table 2). Chemical characterization demonstrated that, after alkali treatment, the chemistry was similar for the three composites. In particular, XRD showed that the diffraction peaks of apatite and copolymer were present in the patterns of all the composites indicating their compositional similarity (Figure 1a). These observations are strengthened by the presence of all vibrational bands of copolymer and apatite in CR patterns of the composites (Figure 1b). Further to this, CR indicated that surface treatment had no effects on the surface chemistry since no additional phase than apatite and polymer were detected (Figure 1b). For more in-depth results about CR analysis on composites containing this copolymer, see also Table 3 in Chapter 4.

After burning the polymer out, the CaP content was similar for M1 and M2 but M0 had slightly less apatite content (ANOVA, $p>0.09$; Table 3 ), which is probably due to the fact that alkali surface treatment removed the polymer from the surface. SEM observations confirmed that alkali treatment exposed apatite particles that were previously covered by the polymer, generating fairly uniform nano-structured surfaces (Figure 2). BSEM of the cross-sectioned granules showed (significant different) increases in the thickness of the exposed apatite layers with increasing treatment strength (ANOVA, $p<10^{-8}$ ) (Figure 2; Table 4). 

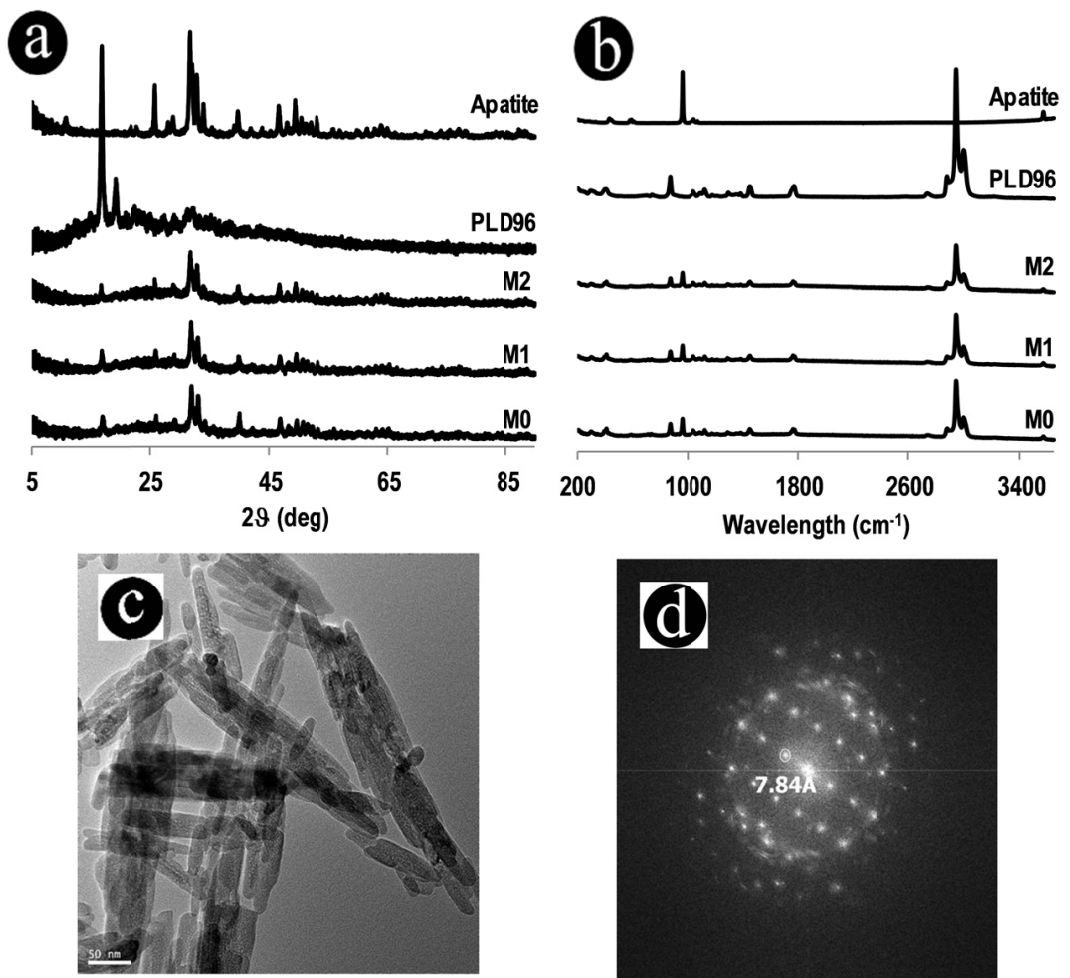

Figure 1. (a) XRD and (b) CR spectra for unsintered apatite, polymer and composites. (c) TEM picture of the unsintered apatite. (d) Selected representative of FFT applied to HRTEM images to measure the dvalue of apatite structure.

\subsubsection{Surface properties (discs)}

Static contact angle measurements indicated significant increase in surface hydrophilicity $(71.8 \pm 0.8,21.0 \pm 1.6$ and $16.6 \pm 0.3 \mathrm{deg}$ for $\mathrm{M} 0, \mathrm{M} 1$ and $\mathrm{M} 2$ respectively) with the increase of the alkali treatment strength (ANOVA, $p<10^{-13}$ ). The increased surface wettability could be linked to the observed increasing apatite exposure on the surface. Two-dimensional AFM images showed that the non-treated discs (i.e. M0) have a 'topographical order' as their surface present quasi-parallel nano-grooves caused by the polishing step during their preparation (Figure 3a). Images of M1 and M2 demonstrated that increasing the strength of alkali surface treatment progressively diminished the level of such topographical order leading to a totally random distributed peak-valley topography in M2 (Figure 3c) whereas traces of nano-grooves are still visible in M1 (Figure 3b). This might be explained with the fact that high $\mathrm{NaOH}$ concentration removes more polymer by hydrolyzing its ester bonds ${ }^{[366]}$, leading to irregularly shaped topography (i.e. peaks and valleys) and to exposure of more apatite particles on the surface (Figure 2). Consequently, besides 
altering the surface topography, the strength of alkali surface treatment also significantly increased the surface roughness as indicated by the measured $\mathbf{R a}, \mathbf{R q}$ and $\mathbf{R z}$ surface indicators (ANOVA, $p<10^{-9}$ for all parameters) of the composites (Table 5).These numerical results were confirmed by the three-dimensional maps (Figure 3). The distribution of recorded heights (i.e. measured as compared to the mean flat plane of the surface) indicated that a strong alkali treatments (i.e. M2) led to the formation of many valleys on the surface due to the higher etching action of sodium hydroxyde which removed more polymer (Figure 4), meanwhile, for M1 there was an increase in the size of peaks and valleys as compared to M0. It is noticeable that to large distributions corresponded to larger roughness as roughness is an index of the variability in height irregularities. However, it should be noted that no porosity was formed as under the surface the bulk was dense as demonstrated by BSEM images (Figure 2). Summarizing, MO had more ordered topography with low roughness whereas M1 and M2 had progressively increasing topographic disorder and roughness.

\subsubsection{In vitro degradation}

During three months the composites degraded as indicated by their mass loss, continuous release of calcium and phosphate ions (Table 6, Figure $5 \mathrm{~d}, \mathrm{e}$ ) and a slight increase in their apatite phase contents compared to the starting conditions (t-test, $p<10^{-6}$ for all) (Table 3). The phase composition after degradation was the same for the three composites (ANOVA, $p>0.06$ ) even if $\mathrm{M} 0$ contained slightly less apatite. However, the three composites did not have significant different bulk degradation as indicated by similar (average) mass loss (Table 6. Please note that, due to the small standard deviation, the statistical comparison gave significant differences amongst the three materials. In practice, such difference is not significative). This observation was supported by BSEM images of cross-sectioned granules showing intact bulks for all the three degraded materials (Figure 5). Slight decrease in apatite layer thickness surrounding M1 and M2 granules were observed (Table 4) indicating that dissolution of the apatite particles exposed on the surface could have occurred. However, these decreases were not significantly large compared to the starting controls (t-test, $p>0.1$ for all), but there was still a significant difference between the materials (ANOVA, $p<10^{-7}$ ). As regards to $M 0$, no surface changes were seen after 3-month degradation in vitro. As expected, due to the initial lack of exposed surface apatite layers, M0 released less calcium and phosphate ions as compared to M1 and M2 (Figure 5d,e; Table 6). Decrease of intrinsic viscosity in all the three materials (Table 2) demonstrated that polymer hydrolysis was triggered most likely by the fluid absorption, which was significantly lower in M0 than M1 and M2 (Table 6). 

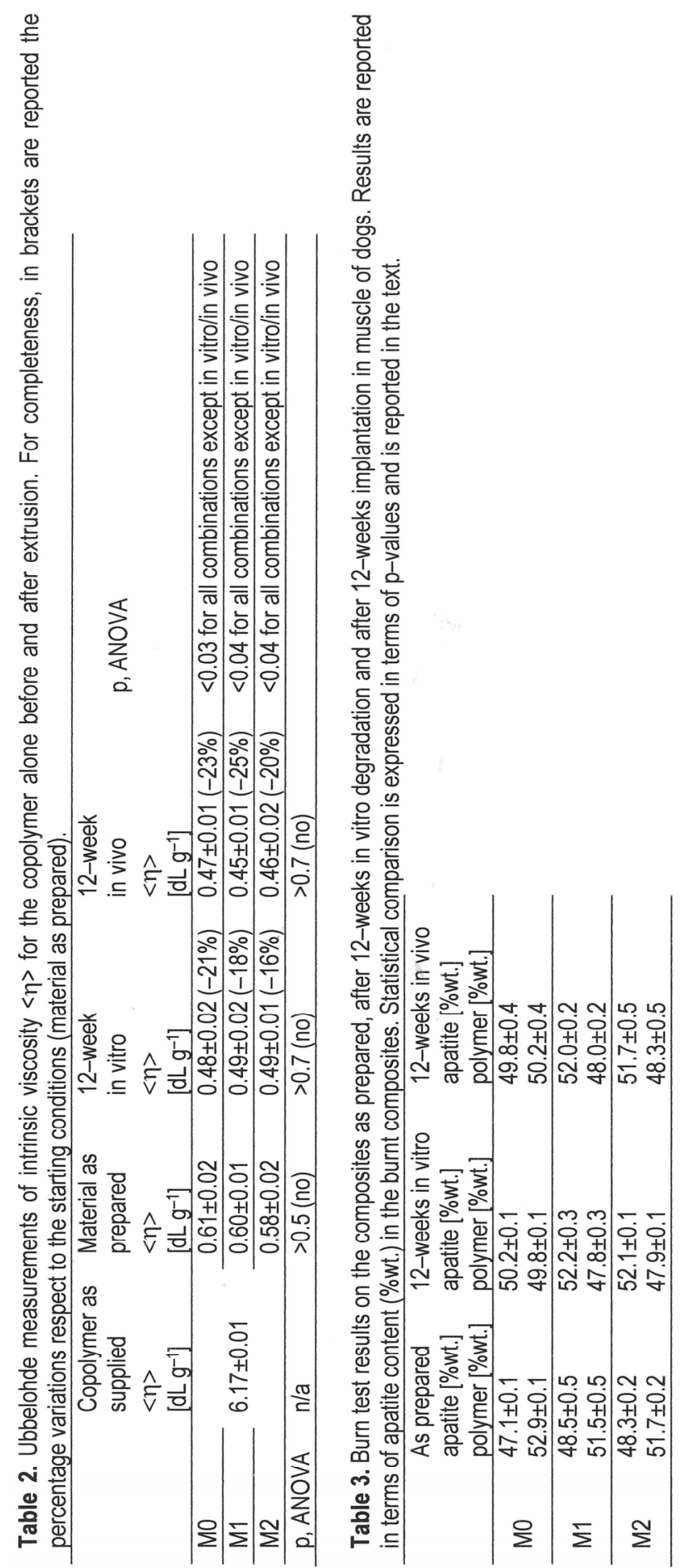

wi

으몸

w o

일

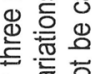

힝

도음

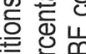

흥

证

焉 要

产 원

$\subseteq$ 元

क

矢

嵌.

造

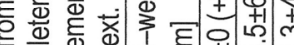

要

尊 今。

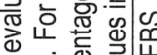

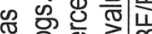

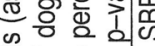

प0 0 क

迸

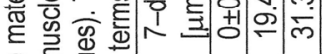

\&

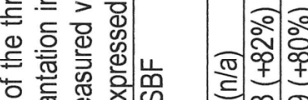

증

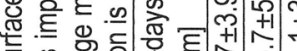

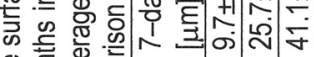

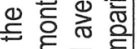

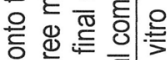

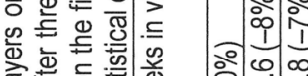

㐫语

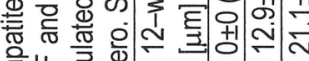

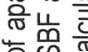

舟

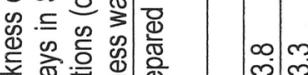

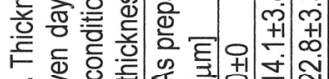

ơ

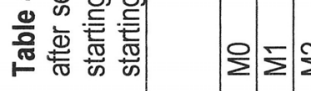



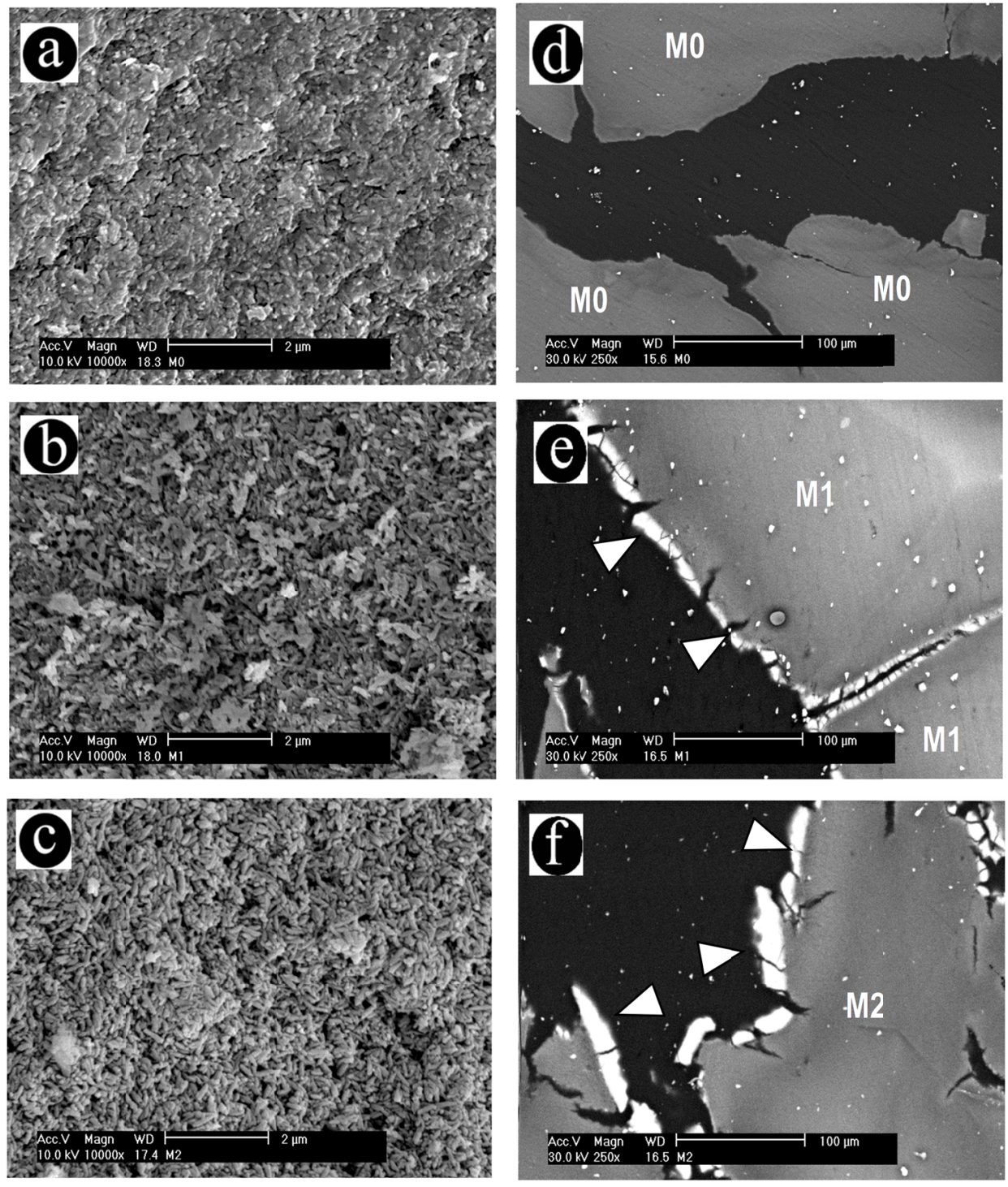

Figure 2. SEM images showing the starting surface of (a) M0, (b) M1 and (c) M2 granules. It can be observed that the surface treatment removed the surface polymer exposing apatite. With the increase of the strength of alkali surface treatment, there was an increase of apatite exposure on the surface. BSEM images of cross-sectioned starting granules were taken for (d) M0, (e) M1 and (f) M2. Increasing thickness in the exposed apatite layers (indicated by white arrows) was observed with the increase of surface treatment strength as $\mathrm{NaOH}$ hydrolyzed and removed the surface polymer. Please note that the 'salt' effect in BSEM images is due to the presence of sand granules after polishing the embedded samples (to remove the top MMA layer from the sectioned block). Confirmation that such granules are sand comes from checking with stereomicroscope. 

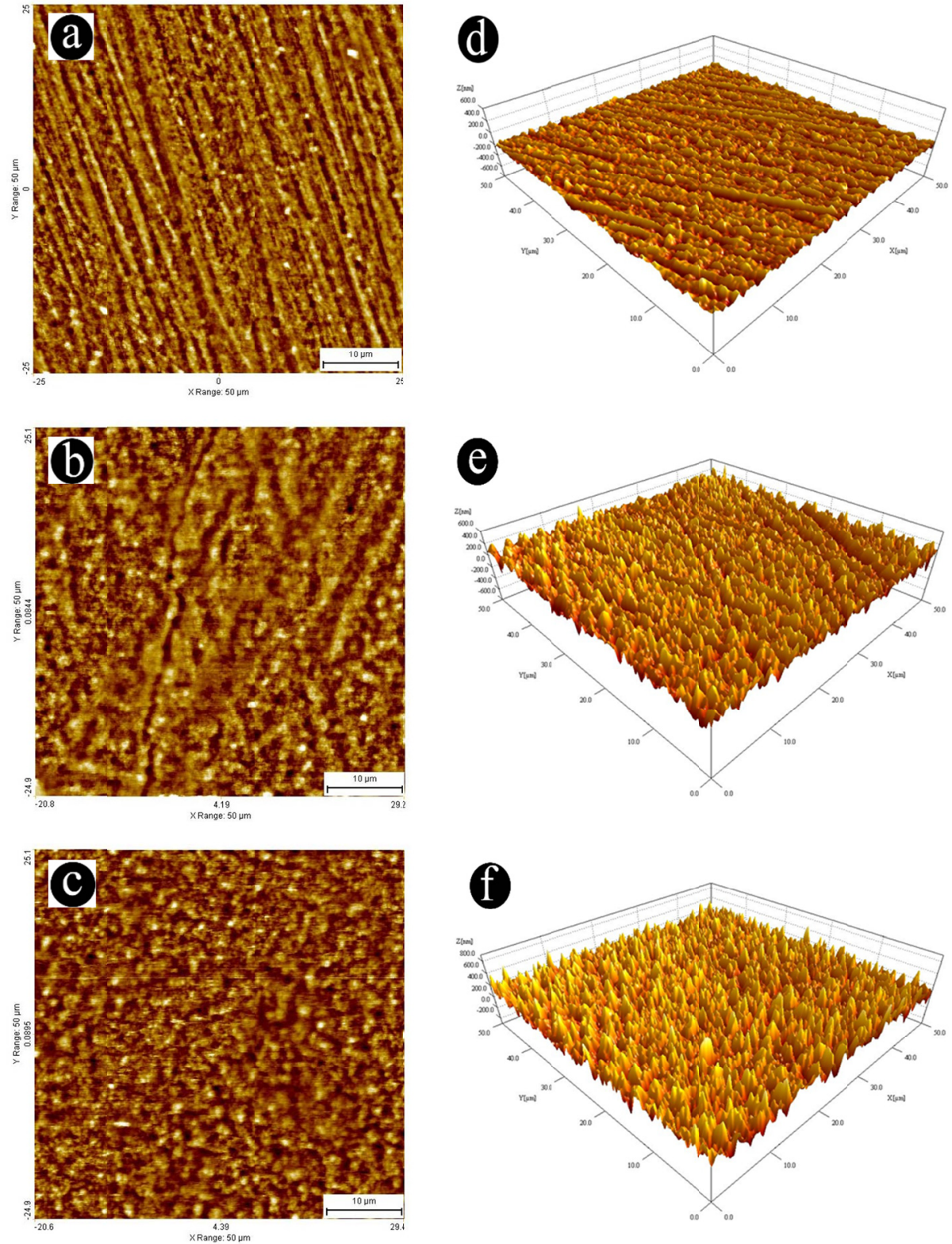

Figure 3. AFM two-dimensional surface maps of (a) M0, (b) $M 1$ and (c) M2 discs, and their corresponding three-dimensional reconstructions of (d) M0, (e) M1 and (f) M2. Two-dimensional maps show that the untreated discs had more ordered topography with quasi-parallel nano-grooves, while the alkali treatment leads to progressive loss of such grooves leading to an increase in topographical disorder. On the two-dimensional maps, the heights are indicated with a color-scale where white indicates the highest positive heights (i.e. peak) and dark brown corresponds to the lowest negative heights (i.e. valley). This color-scale does not apply to the three-dimensional maps. 


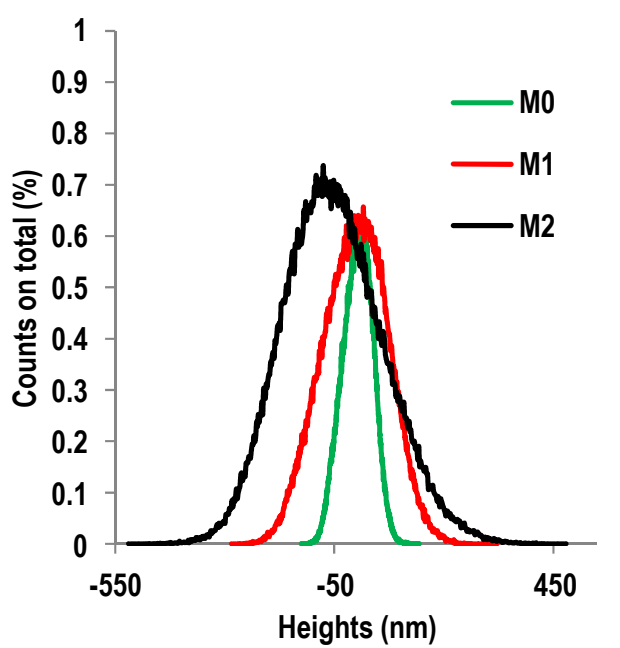

Figure 4. The distribution of recorded heights as compared to the zero-plane shows that stronger alkali surface treatment leads to larger variability in the surface heights.

Table 5. Surface roughness parameters as measured with AFM. Statistical comparison is expressed in terms of $p$-values and is reported in the text.

\begin{tabular}{llll}
\hline & $\mathrm{Ra}$ & $\mathrm{Rq}$ & $\mathrm{Rz}$ \\
& {$[\mathrm{nm}]$} & {$[\mathrm{nm}]$} & {$[\mathrm{nm}]$} \\
\hline $\mathrm{M} 0$ & $27.1 \pm 3.8$ & $33.7 \pm 5.0$ & $258.3 \pm 47.9$ \\
\hline $\mathrm{M} 1$ & $58.2 \pm 4.1$ & $72.3 \pm 4.8$ & $541.5 \pm 89.3$ \\
\hline $\mathrm{M} 2$ & $105.7 \pm 6.3$ & $130.6 \pm 7.8$ & $997.3 \pm 138.3$ \\
\hline
\end{tabular}

Table 6. Calcium and phosphate cumulative ion concentration, mass loss and fluid uptake after 12 weeks in vitro degradation in SPS.

\begin{tabular}{lllll}
\hline & $\begin{array}{l}\text { Calcium release } \\
{[\mu \mathrm{M}]}\end{array}$ & $\begin{array}{l}\text { Phosphate release } \\
{[\mu \mathrm{M}]}\end{array}$ & $\begin{array}{l}\text { Mass loss } \\
{[\%]}\end{array}$ & $\begin{array}{l}\text { Fluid uptake } \\
{[\%]}\end{array}$ \\
\hline M0 & $492 \pm 75$ & $157 \pm 2$ & $10.1 \pm 0.2$ & $2.4 \pm 0.2$ \\
\hline M1 & $710 \pm 120$ & $174 \pm 11$ & $10.8 \pm 0.1$ & $7.5 \pm 0.2$ \\
\hline M2 & $645 \pm 54$ & $175 \pm 3$ & $10.6 \pm 0.1$ & $7.3 \pm 0.3$ \\
\hline p, ANOVA & & & & \\
M0-M1 & $<0.03$ & 0.04 & $<0.01$ & $<10^{-6}$ \\
M0-M2 & $<0.02$ & 0.04 & 0.03 & $<10^{-4}$ \\
M1-M2 & $>0.1$ (no) & 0.7 (no) & $>0.2(\mathrm{no})$ & $>0.65$ (no) \\
\hline
\end{tabular}

It can be said that the fluid uptake results are consistent with the surface treatment effects such as increasing apatite exposure and hydrophilicity for those treated. Negligible $\mathrm{pH}$ changes (i.e. with variations \pm 0.1 around 7.3; Figure 5 f) were seen over the three-week refreshing periods. Such stability might be due to the calcium and phosphate ion buffering action, which may have hindered the catalysis of polymer hydrolysis. 


\subsubsection{In vitro surface mineralisation in basic SBF and SBF/FBS}

After immersion in SBF, all three composites surface mineralised within seven days as indicated by flake-like layers where apatite had spontaneously nucleated. The mineralised surfaces had similar nano-texture amongst the materials (Figure 6a,b,c). It may be observed that the mineralized surfaces had more irregular and larger nanostructured texture than their starting counterparts. BSEM showed significantly thicker apatite layers as compared to the starting granules for all materials (t-test, $p<10^{-4}$ for all, Table 4, Figure 6d,e,f). This indicates that calcium phosphate had precipitated from SBF and nucleated onto the initially exposed apatite particles mineralizing the surfaces. The three materials still presented significantly different apatite layer thickness amongst them after immersion in SBF (ANOVA, $\left.p<10^{-6}\right)$, with increasing thickness in the order M0, M1 and M2. On the other side, when the samples were placed in SBF/FBS, less surface mineralization was observed as compared to the counterparts in SBF. This fact shows an inhibitory effect of proteins on mineralization. It is interesting to observe that, in both cases, the mineralizing rate was similar for M1 and M2 (Table 4). It appears that, once apatite particles were exposed on the surface of composites (i.e. M1 and M2), their potential to surface mineralize was same.

\subsubsection{Protein adsorption from FBS and SBF/FBS}

Rougher surfaces allowed the adsorption of significantly more serum proteins as compared to $\mathrm{MO}$ in both the considered solutions. It is interesting that the roughest surface, i.e. M2, always adsorbed significantly less serum proteins than M1 (Figure 7, Table 7). However, in SBF/FBS serum protein adsorption was significantly enhanced for all the three materials as compared to FBS alone situation (Figure 7, Table 7). At the same time, M1 still adsorbed significantly more proteins than M2.

\subsection{6. rhBMP-2 adsorption on discs}

Consistently with serum protein adsorption results, rougher surfaces allowed the adsorption of significantly more rhBMP-2 as compared to M0 (Table 7). However no significantly different amounts of rhBMP-2 were adsorbed by M1 and M2.

\subsection{7. hBMSCs cell culture}

The composites supported the proliferation and differentiation of hBMSC cells for two weeks. Rougher surface allowed significant less cell proliferation at all time points (DNA) (ANOVA, $p<0.03$ ) (Figure 8) but more osteogenic differentiation, particularly after four days (ALP/DNA) (ANOVA, $p<0.02$ ) (Figure 8). 

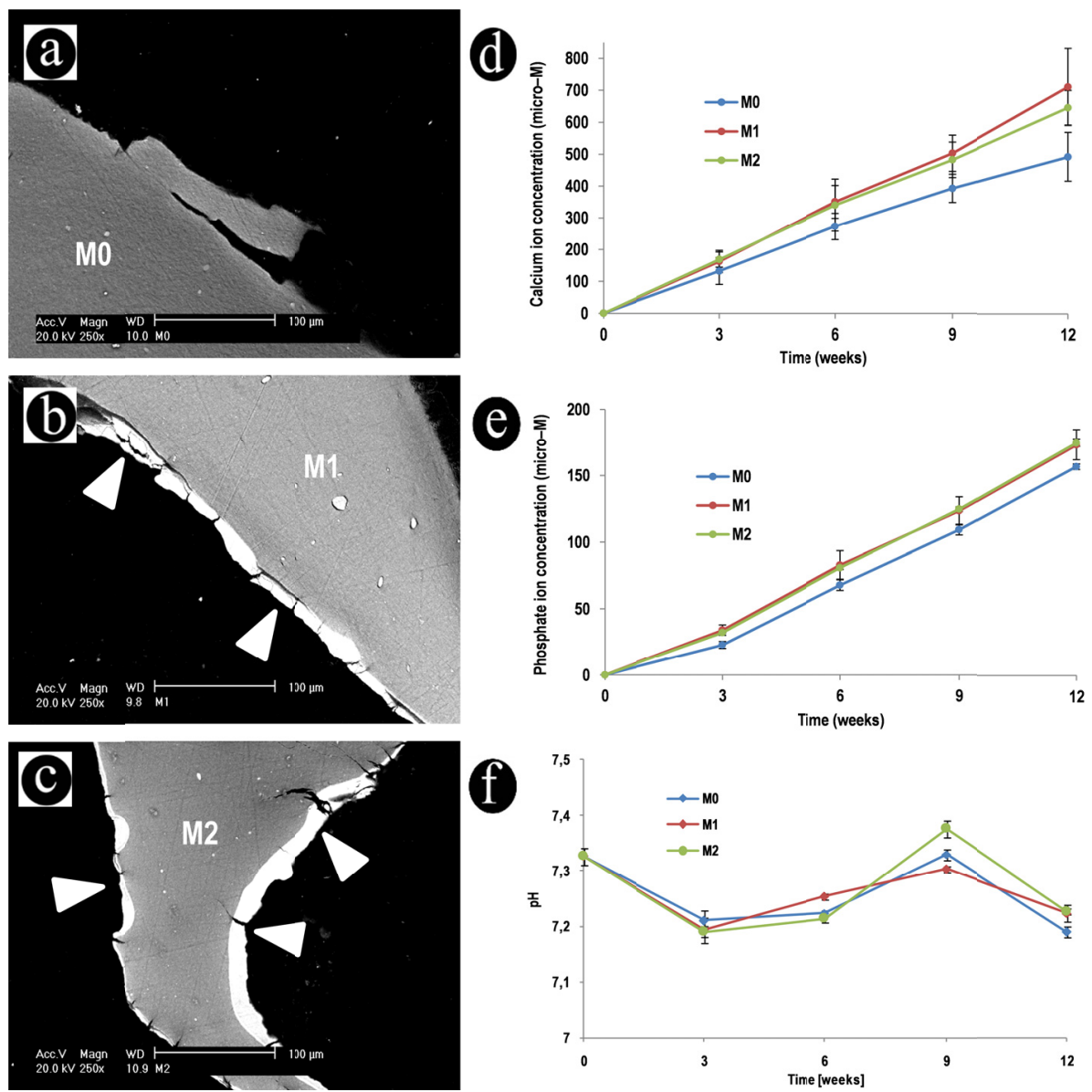

Figure 5. BSEM images of the cross-sectioned (a) M0, (b) M1 and (c) M2 granules after three months in SPS. (d) Calcium and (e) phosphate cumulative ion concentration in SPS over 12 weeks. (f) pH variations (during the four periods between refreshments) of the degrading medium over three months. Please note that the 'salt' effect in BSEM images is due to the presence of granules of sand paper after polishing the embedded samples for the electron microscopy observations as explained in the caption of Figure 2. 

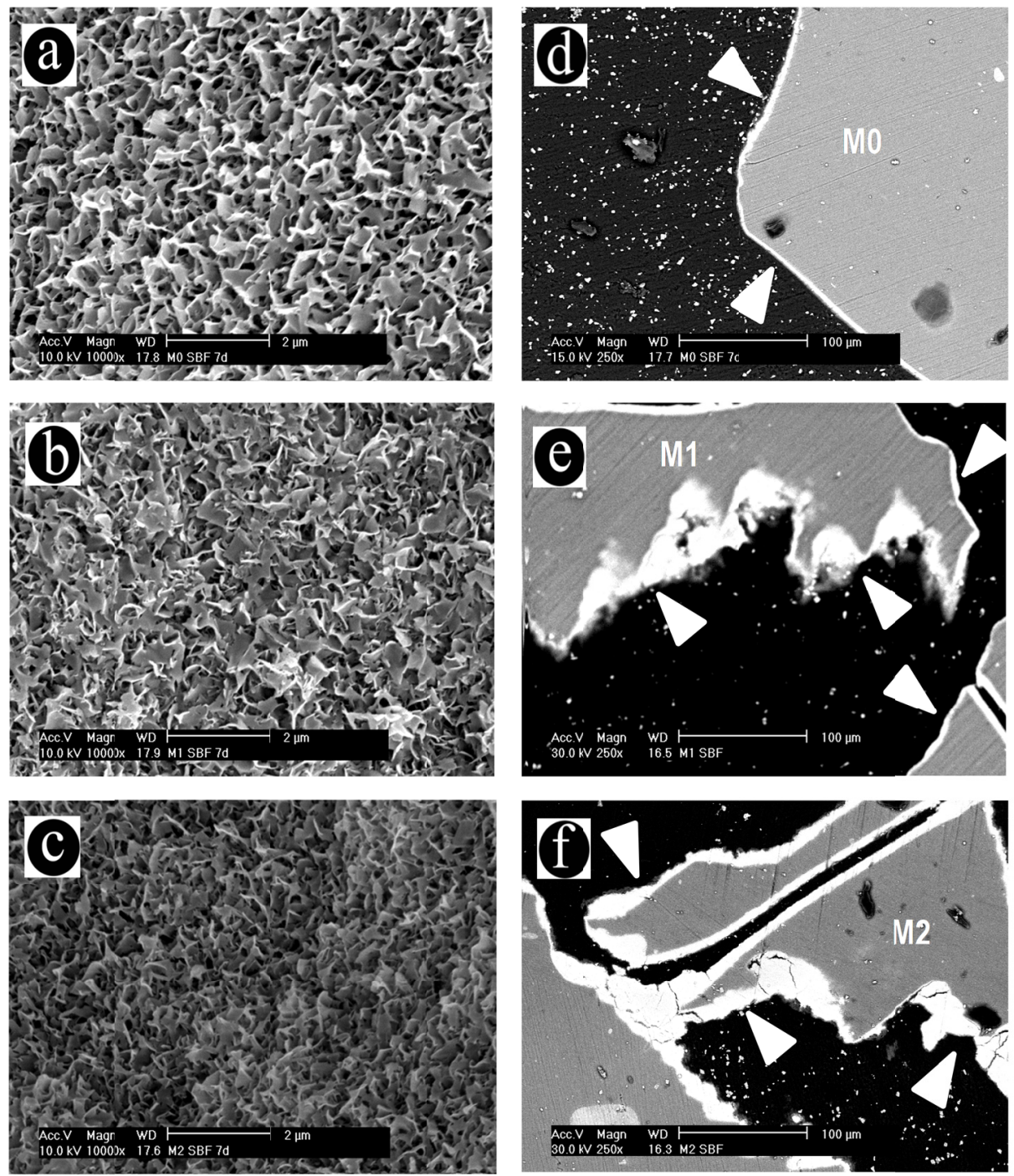

Figure 6. SEM images of mineralised surfaces of (a) M0, (b) M1 and (c) M2 granules after seven days in SBF. Nano-structured surface texture could be observed on both composites. BSEM images of crosssection of (d) M0, (e) M1 and (f) M2 granules after two days in SBF. White triangles indicate the apatite layers around the granules, which were thicker compared to the starting controls (Figure 2). This indicates that calcium phosphates precipitated from SBF on the three materials. Please note that the 'salt' effect in BSEM images is due to the presence of granules of sand paper after polishing the embedded samples for the electron microscopy observations (as explained in the caption of Figure 2). 


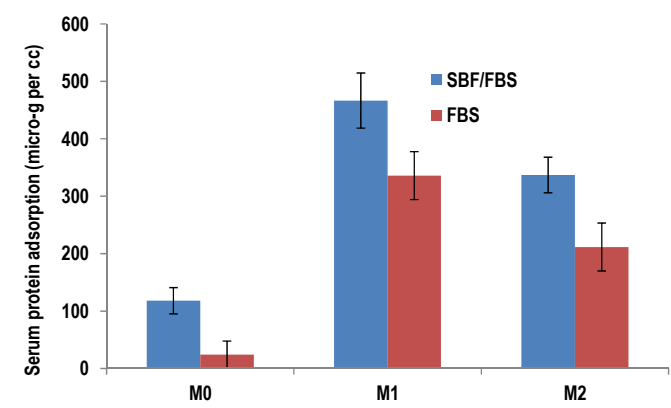

Figure 7. Serum protein and from SBF and SBF/FBS solutions after one week. Statistical comparison is expressed in terms of $p$-values and is reported in Table 7.

Table 7. Statistical comparison of serum protein adsorption after seven days in FBS and SBF/FBS. The left side of the Table makes comparison amongst the materials per each solution (i.e. analyses effect of roughness on protein adsorption), while the right side compares the effect of the kind of solution on protein adsorption. The test used was one-way ANOVA test for means (Tukey's) where a p-value smaller than 0.05 was considered as significant difference.

\begin{tabular}{|c|c|c|c|c|}
\hline & FBS & SBF/FBS & & \\
\hline Between materials & & & Between solutions & \\
\hline M0-M1 & $10^{-5}$ & $10^{-5}$ & M0 & 0.0087 \\
\hline M0-M2 & $10^{-4}$ & $10^{-4}$ & M1 & 0.0014 \\
\hline M1-M2 & 0.03 & 0.001 & M2 & 0.0027 \\
\hline
\end{tabular}

Table 8. rhBMP-2 adsorption on composite discs, with statistical test used (i.e. one-way ANOVA test for means (Tukey's) where a p-value smaller than 0.05 was considered as significant difference).

\begin{tabular}{ll|ll}
\hline & $\begin{array}{l}\text { Adsorbed rhBMP-2 (1 day) } \\
\text { [ng per disc] }\end{array}$ & \multicolumn{2}{l}{ p, ANOVA } \\
\hline M0 & $3.8 \pm 0.6$ & M0-M1 & $<0.04$ \\
M1 & $7.3 \pm 0.9$ & M0-M2 & $<0.045$ \\
M2 & $7.5 \pm 1.1$ & M1-M2 & 0.8 (no) \\
\hline
\end{tabular}

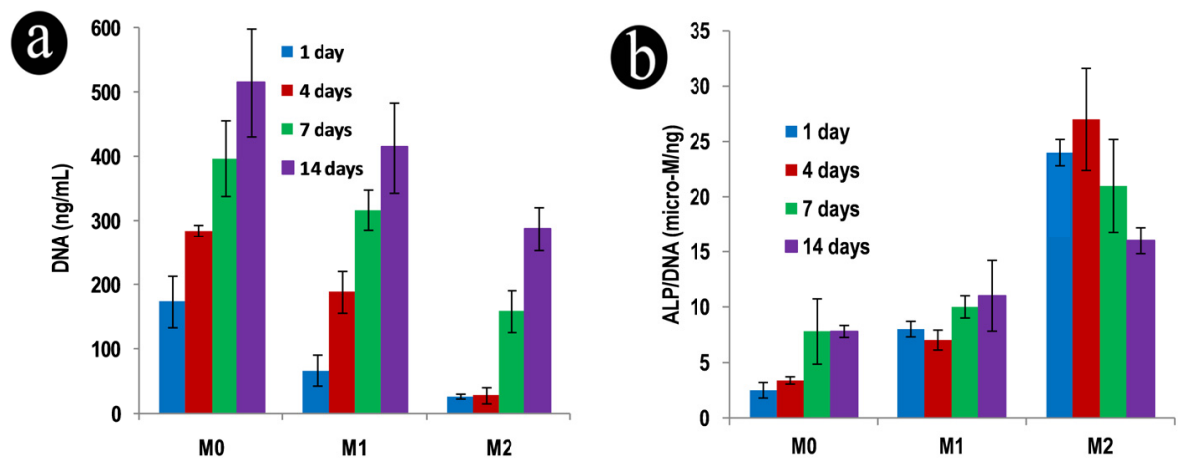

Figure 8. (a) Proliferation expressed as DNA production and (b) osteogenic differentiation of hBMS cells as ALP/DNA ratio. Statistical comparison is expressed in terms of $p$-values in the text. 


\subsubsection{Animal experiments}

A total of six samples per material were intramuscularly implanted in six dogs. After 12 weeks, all samples were retrieved and they were surrounded by a thin layer of connective tissue and then muscle tissue. As shown in the histological overviews (Figure 9), after 12 weeks of implantation all specimens retained the initial shape and size of the granules. However, no bone was observed in any of the composites. Observations at BSEM showed that, as compared to the starting materials, average thicker apatite layers surrounding M1 and M2 granules could be seen. However, their increase compared to their starting counterparts was not significant (t-test, $p>0.31$ for M1, and $p>0.1$ for M2) (Table 4, Figure 9). The resulting apatite layers had significantly different thickness amongst the three materials (ANOVA, $p<0.03$ ), with M0 not presenting any apatite particles exposure and M2 having the thickest layers. These observations are in line with the results from in vitro mineralization experiment (Table 4), where M2 had the thickest layers and M0 the thinnest. Intrinsic viscosity of the copolymer phase decreased similarly in all the three materials as compared to their starting counterparts (Table 2) indicating that polymer hydrolysis occurred. However, as shown by BSEM images (Figure 9), bulk erosion did not occur yet in any of the explants as the core of the granules was still as dense and compact as their starting situation. The explants, as shown by histology overviews (Figure 9), were very compact presenting granules close to each other (not much available space was observed). Furthermore, comparing the final composition of the explants (Table 3), no differences were seen amongst the three materials (ANOVA, $p>0.2$ ).

\subsection{Discussion}

We prepared three composites of apatite and $96 \% \mathrm{~mol}$. L-lactide $/ 4 \% \mathrm{~mol}$. D-lactide copolymer having three different levels of surface roughness, which was directly linked to the topographical disorder. Clashing with our expectances, none of them supported heterotopic bone formation after twelve weeks intramuscular implantation in dogs. In fact, we expected that the rougher and topographically more disordered surfaces (i.e. M2) would have triggered the osteoinduction process because, consistently with literature, ${ }^{[195,363]}$ they diminished human bone marrow stromal stem cell osteoblastic proliferation but increased their osteogenic differentiation compared to their smoother counterparts (Figure 8). It is suggested that osteogenic stem cells are anchorage-dependent and they adhere well on nanorough surfaces able to adsorb proteins, ${ }^{1153,362,367]}$ including fibronectin and vitronectin that facilitate focal adhesion ${ }^{[371-373]}$ and cytoskeleton reorganization. ${ }^{[374]}$ At the same time, increased surface roughness is reported to enhance osteogenic differentiation, ${ }^{[363]}$ probably because such nano-texture can adsorb higher amounts of 
osteo-stimulating proteins than smooth surfaces. However, we observed that the adsorption of rhBMP-2 after one day was similar for M1 and M2, so we assumed that their protein adsorption potential is same. Thus, the higher osteogenic differentiation caused by M2 was most likely affected by the larger roughness.

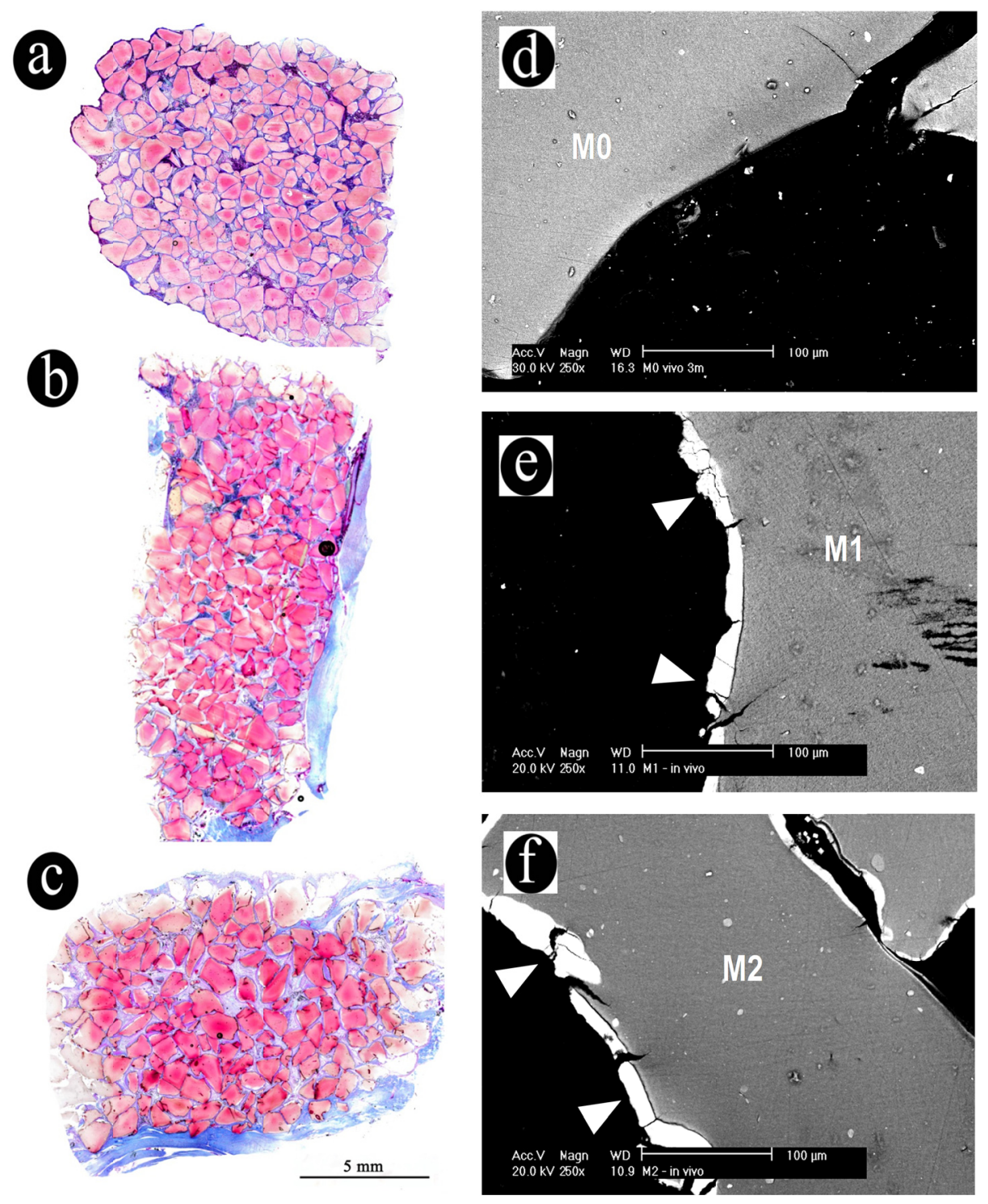

Figure 9. Overviews of the explanted (a) M0, (b) M1 and (c) M2 samples. No bone formation occurred in any of the materials. BSEM images of histology sections of (d) M0, (e) M1 and (f) M2 showing the surface apatite layers (indicated by white arrows). 
This conclusion is strengthened by their similar in vitro degradation, mineralization trends and serum protein adsorption (§5.3.3., §5.3.4. and §5.3.5.), indicating that no other factors than surface roughness were involved in inducing the different cellular performances.

In this study, the failure of the in vitro model to predict the in vivo performance of composites indicates that, in biomaterials science, extrapolating in vitro biological results (e.g. cell culture or protein adsorption) into in vivo performances is a complex issue. In vitro models reduce the intrinsic variability present in living bodies simplifying the system. For example, as mentioned in §5.2.8., in this study we decided to culture cells onto discs to avoid cell seeding and nutritional inhomogeneities usually associated to three-dimensional systems such as (porous) granules. Further, when a material is placed in cell culture, it enters in contact with a closed system having culture medium and its composition (i.e. proteins, nutrients) carefully chosen where $\mathrm{pH}$, carbon dioxide concentration and temperature are strictly stabilized. Besides this, cells are chosen and no other undesired lines or organisms are present to interfere with the used ones. On the contrary, if the same material is placed in the body, many factors that are not included in an in vitro culture system play roles on the overall performance of the material. For example, inflammation and foreign body reaction attract other forms of cells such as monocytes and macrophages which then release cytokines further recruiting other kinds of cell.[217, 256, 257] During this reaction, the material may degrade due to phagocytosis ${ }^{[375]}$ and may change its properties affecting on its own performance. Further, body fluids have more heterogeneous composition than culture medium rendering the in vivo interaction between cells and materials surface more complex than in vitro.

However, in this study we demonstrated that alkali treating the surface of the composite with sodium hydroxide solutions generated differently disordered nanorough surfaces. In particular, the stronger treatment led to topographically disordered surfaces with higher roughness (Figures 3 and 4, Table 5). The enhanced surface nano-structure is likely caused by the hydrolysis of the polymer matrix [366] and by the consequent larger exposure of apatite on the surface (as shown by thicker apatite layers surrounding M1 and M2, Figure 2). The water contact angle of the composites diminished with the strength of the surface treatment indicating an increase of their polar character. This may be partially caused by the formation and exposure of polar groups due to the polymer hydrolysis provoked by the alkaline treatment, ${ }^{[366]}$ and partly by the exposure of larger amount of hydrophilic apatite.

The composites degraded over three months as indicated by their mass loss (Table 6 ), which resulted similar with each other. However, higher concentrations of calcium and phosphate ions in SPS containing M1 and M2 as compared to M0 were observed 
(Figure 5; Table 6). Consistently to these observations, the bulk of all three samples was similar (i.e. dense at BSEM, Figure 5) and the polymer phase hydrolysis was similar (i.e. comparable decreases in intrinsic viscosity, Table 2). At the same time, similar decreases in the apatite layer thickness around M1 and M2 were seen (Table 4). All these observations indicate that the more pronounced ion release from the treated materials is likely caused by the dissolution of the surface apatite particles, which were exposed in larger quantities in M1 and M2. Summarizing, the alkali treatment influenced on the ion release as it allowed exposure of apatite particles on the surface and their direct contact with fluids.

It has been suggested that calcium and phosphate ions also favor surface mineralization, and it is well known that the presence on the surface of some functional groups, particularly those polar such as carboxyl and hydroxyl, renders the surface more hydrophilic and positively influences on the spontaneous apatite precipitation onto the surfaces. ${ }^{[245]}$ Hydrophilic surfaces were reported to favor surface mineralization because they enable better coverage of the surface by the body fluids and significantly accelerate the nucleation and precipitation resulting in deposited mineral. ${ }^{[410]}$ Consistently, we observed that $\mathrm{M} 0$, as compared to the more hydrophilic M1 and M2, had lower mineralization potential. After one week in SBF, significant increases in the thickness of apatite layers surrounding granules were observed for all the three materials (Table 4). We also saw that in vitro mineralization occurred at similar rate for $\mathrm{M} 1$ and $\mathrm{M} 2$ indicating that increasing the alkali treatment strength or the surface hydrophilicity did not have any role on the in vitro surface mineralizing potential. XRD and CR highlighted the presence of apatite also on M0 surface even if no clear layers were seen at BSEM (Figure 2). Most likely, apatite was partially embedded in the polymer at the surface of the composite. Considering this fact, we conclude that the sole (full or partial) exposure of apatite particles on the surface is sufficient to trigger in vitro mineralization in SBF.

Interestingly, we observed that the surface mineralization rate of the composites is decreased when the samples were placed in SBF containing serum. This can be correlated with the fact that the apatite nucleation sites, in this situation, are also binding sites for proteins. Besides adsorbing onto the exposed apatite initially present on the composites surface, serum proteins may have adsorbed also on the growing mineralized layers. When proteins bound to the apatite nucleation sites (i.e. the starting exposed apatite and/or the precipitated apatite), they may have reduced their availability for further apatite precipitation and growth. This fact was already reported in literature for hydroxyapatite and biphasic calcium phosphate ceramics. ${ }^{[376,377] \text { In }}$ particular, it was observed that albumin, which is the most abundant protein in serum, plays a crucial role in this inhibitory process. ${ }^{[376,377]}$ This protein-controlled 
mineralization process has been suggested to occur in living organisms. ${ }^{[378]}$ Thus, alkali surface treatment improved the surface mineralising potential of the composites, which decreases in presence of proteins.

Significant more serum proteins adsorbed onto the treated composites as compared to the non-treated one. The better performances in protein adsorption may be assigned to the larger exposure of apatite particles and/or to the improved surface nano-texture of the surface-etched materials. However, despite its larger nanoroughness M2 adsorbed less serum proteins than M1. This may be connected to the larger surface hydrophilicity of M2 compared to M1. It has been suggested that the formation of a layer of water on hydrophilic surfaces generates an energy barrier for the adsorption of most proteins $[379,380,381]$ because they need to change their conformation to reach an energetic equilibrium with the surface. However, some proteins such as albumin are reported to be conformationally 'flexible' protein able to adsorb also on hydrophilic surfaces. ${ }^{[382]}$

As discussed earlier, surface mineralization occurred in SBF/FBS solution generating apatite nano-textured surfaces which offered more adsorption sites to proteins for their adsorption. At the same time surfaces in contact with serum alone did not mineralize and thus had less adsorption sites available (i.e. only the apatite initially exposed on their surfaces). Consequently, surface mineralization significantly increased the adsorption of serum proteins and albumin in all the considered materials. This may be related to the apatite based chemistry and nano-structure of the precipitated layers. This fact is strengthened by the reporting that proteins, such as fibronectin and vitronectin, adsorb in larger amounts onto rougher surfaces, ${ }^{[383,384]}$ and they are calcium-affine.[153, 250, 251, 346]

\subsection{Conclusion}

Summarizing, the roughest material (i.e. M2) adsorbed proteins, generated a mineralised surface and was able to trigger osteogenic differentiation. In view of these properties we expected it would have at least initiated bone formation but it did not. This study showed that surface roughness is a parameter that should be kept in mind when designing biomaterials as it affects the final material properties and can have implications on its biological performances, both in vitro and in vivo. However, it is necessary to carefully consider the fact that in vitro biological systems (e.g. cell culture, protein adsorption) used to study the biomaterial may lead far from the real in vivo performance of the material. 


\section{CHAPTER 6}

Fluid uptake as instructive factor in biomaterials for bone tissue regeneration 



\section{Remarks}

We would like to remind the readers that the three polymers used in this study have been already evaluated in this thesis (see Chapters 4, 5 and 7). We observed that, despite their different (high) starting inherent viscosity (i.e. weight average molecular weight), after extrusion with $50 \%$ wt. apatite particles their molecular weight reached very low values, which were nearly comparable. Thus, to design studies aiming to evaluate the effect of polylactide monomer chemistry on the final characteristics of the composites, we have striven to optimize the extrusion process (i.e. temperature) to obtain similar molecular weights in the polymer phases of each final composite.

\subsection{Introduction}

Cell behavior is instructed by various physical, mechanical and chemical stimuli exhibited by the surrounding environment. It is proposed that the extra-cellular fluid (i.e. ECF) component of body fluids is an important actor in such instructing system [3437, 96-98] and participate in many phenomena including tissue regeneration and foreign body and inflammatory reactions. ${ }^{[95,96]}$ Cells can bind to specific molecules (i.e. ligands such as growth factors and cytokines) transported by ECF. ${ }^{[96]}$ Such molecules trigger certain intracellular processes determining cell fate. For instance, during inflammatory reaction, endocrine organs secrete biomolecules that, via the ECF, reach and affect distant cells. ECF also carries instructive biomolecules, e.g. VEGF and rhBMP-2, that can induce the differentiation of cells into specific phenotypes enhancing tissues regeneration, ${ }^{[110,135]}$ and it contains various ions crucial for life. For example, during new bone matrix formation collagen micro-fibrils mineralize by sequestrating calcium and phosphate ions dissolved in $\operatorname{ECF}^{[385,386]}$ thus strengthening the load-bearing skeleton in vertebrates.

Various biomaterials have been proposed as 'instructive' for bone tissue regeneration in critical-sized defects, such as calcium phosphate ceramics and their composites with polymers. Their instructive potential (i.e. osteoinduction) is demonstrated when they can induce bone formation in heterotopic sites such as in muscle and under skin. By virtue of their surface micro- and nano-structure, a few calcium phosphate ceramics $^{[228,236,237]}$ and composites (in this thesis) have shown enhanced calcium and phosphate ion release, protein adsorption and surface mineralization. The combination of these characteristics is supposed to provide suitable instructive conditions that allow heterotopically induced stem cells to differentiate into boneforming lineages. ${ }^{[86,228]}$ Interestingly, it was also observed that composites which are able to take more fluid could initiate bone formation in muscle of dogs (see Chapter 7 in this thesis). However, it should be mentioned that the amount and type of protein 
adsorbed would play important roles in osteoinduction as well, $[153,250,251,346]$ and thus there is need of further studies.

Upon implantation of biomaterials, a cascade of reactions is triggered by the initial injury of the vascularized tissue and by interactions between ECF and the material.[161] During the earliest period following surgery, the contact between ECF and the surface of biomaterials allows quick adsorption of biomolecules occurs. Further to this, the injury of the surrounding tissues and vessels triggers the coagulation and complement systems leading to temporary thrombus-like layers onto the biomaterial surface. ${ }^{[216]}$ Such layers contain structural, biochemical and cellular elements necessary for foreign body reaction and wound healing. In particular, they release biomolecules such as growth factors, chemo-attractans and cytokines into the ECF, which are then diffused towards the surrounding tissues. These molecules recruit phagocytes, including macrophages, to the implant site and modulate their activity. ${ }^{[215]}$ Once macrophages reach the biomaterial, they can adhere and colonize its surface. At this point, it is interesting to observe that the initial inflammation provoked by biomaterials has been suggested to trigger osteoinduction, where the colonization of the material by macrophages is considered a prerequisite. When cultured on osteoinductive biomaterials, macrophages synthesized and secreted cytokines, like prostaglandin E2,[386] that may help recruiting stem cells from the vicinity and induce their osteogenic differentiation. This may happen also in vivo since, iln the specific case of instructive ceramics, upon their implantation monocytes and macrophages colonize their surface at early moments, while bone is formed later. ${ }^{[218-220]}$ Besides inflammation, calcium and phosphate ions dissolved in ECF can precipitate and nucleate onto the biomaterial surface generating nano-structured mineralized layers that may promote, besides protein adsorption by virtue of the large surface area, also cell adhesion, proliferation and osteogenic differentiation. [152, 153, 195, 234, 245, 246, 248-250] After heterotopic implantation of osteoinductive calcium phosphatebased materials, an adequate and quick ECF uptake would improve the contact between biomolecules and the material. This will favor coagulation, protein adsorption, ion (re)-precipitation and their mineralization into layers. At the same time, large uptake of body fluids would trigger the dissolution of calcium phosphate components that will release ions, which may act as 'attractant' for inflammatory cells. ${ }^{[254]}$ Such cells would later secrete cytokines attracting un-differentiated (stem) cells towards the biomaterial.[217] The presence of previously adsorbed proteins and mineralized surface would help their adhesion and differentiation into osteogenic phenotypes initiating bone formation. To summarize, ECF may have key roles in the cellular response to implants and could have an indirect 'instructive' action during the subsequent tissue healing and regeneration processes. 
Therefore, here we hypothesize that post-implantation quick fluid uptake is one of the necessary conditions to trigger osteoinduction because of its possible influence on ion release (by virtue of degrading the material), protein adsorption and surface mineralization. To test this hypothesis on a general view, we considered two classes of materials: micro-structured calcium phosphate ceramics and composites of apatite nano-particles with polylactide. The chosen ceramics differed in their micro-structure surface (i.e. grain and pore size, thus their surface area), which has been reported largely affecting on its biological properties. $[86,228,236,237]$ We believe that a ceramic with larger surface area, i.e. higher micro-structure and microporosity, would allow larger fluid uptake and thus renders such ceramic more osteoinductive. Here, we evaluated two tricalcium phosphate ceramics (TCP) having different micro-structure. On the other side, it is known that the monomer chemistry of polylactide influences on its properties and performances. In particular, high content of L-lactide monomer renders the polymer semi-crystalline, with slow degradation rate and high stiffness, ${ }^{[387]}$ whereas high presence of $D, L$-lactide monomers originates amorphous polymers with higher damping performances and faster degradation. [387] Therefore, a composite containing high L-lactide monomer would absorb less fluids resulting less prone to trigger heterotopic bone formation. Thus, in this study we prepared composites using three polylactide(s) having different Llactide contents.

Therefore, we studied the fluid uptake, protein adsorption and surface mineralization potentials, along with the degradation/dissolution trends of all these materials. Later we implanted them in muscle of sheep to evaluate their osteoinduction potential over a period of six months.

\subsection{Materials and Methods}

\subsubsection{Preparation and characterization of tricalcium phosphate ceramics}

Porous cylinders $(\varnothing 7 \times 10 \mathrm{~mm})$ of micro-structured tricalcium phosphate ceramic with different grain size (i.e. small and big, TCPS and TCPB respectively) were kindly provided by Xpand Biotechnology BV (Bilthoven, the Netherlands). The chemistry of the ceramics was evaluated with X-ray diffractometry (XRD, MiniFlex II, Rigaku, Japan) using $\mathrm{Cu} \mathrm{K}$ radiation $(\lambda=1.54056 \AA)$ operating at $30 \mathrm{kV}$ and $15 \mathrm{~mA}$. Spectra were collected at $0.083 \mathrm{deg} \mathrm{sec}^{-1}$ in the $2 \vartheta$ range $25-45$ deg and later analysed with the software Jade (v6.5.26, Materials Data Inc., Livermore, CA, USA). FTIR was run according a typical $\mathrm{KBr}$ pellet protocol and spectra were collected in the range 400$4000 \mathrm{~cm}^{-1}$ and analysed with the software OriginPro (v8.0773, OriginLab Corporation, Northampton, MA, USA) without any pattern elaboration. The surface characteristics, i.e. micro-structure, grain size and porosity, were evaluated with scanning electron 
microscopy (SEM) in secondary electron modality. The porosity, along with specific surface area and pore distribution, was studied outsource with mercury intrusion (Micromeritics Instr. Corp., Norcross, GA, USA). The dissolution rate of the ceramics has been evaluated in a simulated physiological solution (SPS) prepared by dissolving $\mathrm{NaCl}$ (Merck, Darmstadt, Germany; concentration $8 \mathrm{~g} \mathrm{~L}^{-1}$ ) and 4-(2hydroxyethyl)-1-piperazineethane-sulfonic acid (HEPES) (Sigma-Aldrich, Steinheim, Germany; concentration $11.92 \mathrm{~g} \mathrm{~L}^{-1}$ ) in distilled water. The $\mathrm{pH}$ of the solution was adjusted to 7.3 with $2 \mathrm{M} \mathrm{NaOH}$ (Sigma-Aldrich). Calcium ion release was evaluated by soaking the ceramic cylinders in $100 \mathrm{~mL}$ of SPS at $37 \pm 1^{\circ} \mathrm{C}$ for eight hours. While carefully stirring at $150 \pm 5 \mathrm{rpm}$ with stirring bar $(\mathrm{L}=24 \mathrm{~mm} ; \varnothing=6 \mathrm{~mm})$ avoiding the contact between bar and cylinders, the calcium ion concentration in SPS was continuously recorded every minute using a calcium electrode (Metrohm 692 ISE meter, $\mathrm{Ag} / \mathrm{AgCl}$ reference electrode, Metrohm, Herisau, Switzerland).

\subsubsection{Apatite preparation and characterization}

Nano-apatite powder was synthesized by adding $\left(\mathrm{NH}_{4}\right)_{2} \mathrm{HPO}_{4}$ (Fluka, Steinheim, Germany) aqueous solution ( $\mathrm{c}=63.1 \mathrm{~g} \mathrm{~L}-1$ ) to $\mathrm{Ca}\left(\mathrm{NO}_{3}\right)_{2} \cdot 4 \mathrm{H}_{2} \mathrm{O}$ (Fluka) aqueous solution ( $\mathrm{c}=117.5 \mathrm{~g} \mathrm{~L}^{-1}$ ) at the controlled speed of $12.5 \mathrm{~mL} \mathrm{~min}^{-1}$ and $80 \pm 5^{\circ} \mathrm{C}$, with the reaction $\mathrm{pH}$ kept above 10 by using ammonia (Fluka). After precipitation, the resulting powder was aged overnight, washed with distilled water to remove ammonia, dehydrated in acetone (Fluka) and finally dried at $60 \pm 1^{\circ} \mathrm{C}$. Its chemistry was then investigated with X-ray diffractometry (XRD, MiniFlex II, Rigaku, Japan) using Cu K radiation $(\lambda=1.54056 \AA)$ operating at $30 \mathrm{kV}$ and $15 \mathrm{~mA}$. Spectra were collected at $0.083 \mathrm{deg} \mathrm{sec}^{-1}$ in the 29 range 5-60 deg and later analysed with the software Jade (v6.5.26, Materials Data Inc., Livermore, CA, USA). FTIR was run according a typical $\mathrm{KBr}$ pellet protocol and spectra were collected in the range $400-4000 \mathrm{~cm}^{-1}$ and analysed with the software OriginPro (v8.0773, OriginLab Corporation, Northampton, MA, USA) without any pattern elaboration. The apatite particle size and morphology were characterized using transmission electron microscopy (TEM, Tecnai-200FEG, FEI Europe, Eindhoven, the Netherlands).

\subsubsection{Composites preparation and characterization}

The precipitated powder was extruded with three different polymers in a ratio 50/50\%wt. apatite/polymer to make three composites. The polymers used were $96 \%$ mol. L-lactide/4\%mol. D-lactide copolymer (PLD, declared inherent viscosity $5.67 \mathrm{dL} \mathrm{g}^{-1}$ with residual monomer $\left.<0.2 \%\right), 70 \%$ mol. L-lactide $/ 30 \% \mathrm{~mol}$. D,L-lactide copolymer (PLDL, declared inherent viscosity $3.85 \mathrm{dL} \mathrm{g}^{-1}$ with residual monomer $<0.5 \%$ ) and poly(D,L-lactide) (PDL, declared inherent viscosity $4.02 \mathrm{dL} \mathrm{g}^{-1}$ with 
residual monomer $<2.5 \%$ ). All polymers were kindly supplied by Purac Biomaterials (Gorinchem, the Netherlands). The extrusion was done using a mini vertical conic twin-screws extruder (RD11-H-1009-025-4, DSM Research BV, Geleen, the Netherlands; top screw diameter: $10 \mathrm{~mm}$; bottom screw diameter: $4.15 \mathrm{~mm}$; screw thread: $8 \mathrm{~mm}$; screw length: $108 \mathrm{~mm}$ ) with different temperatures according to the polymer (i.e. $205 \pm 1^{\circ} \mathrm{C}$ for PLD, $195 \pm 1^{\circ} \mathrm{C}$ for PLDL and $190 \pm 1^{\circ} \mathrm{C}$ for PDL), screws speed set at $100 \pm 1 \mathrm{rpm}$ for a mixing time of $5 \pm 0.5$ minutes. Granules $(0.5-1 \mathrm{~mm})$ were obtained by grinding the extruded green bodies at $14000 \mathrm{rpm}$ for 15 seconds without particle size filter (ZM 100 grinder, Retsch, Haan, Germany) and then by hand sieving (sieves $0.5 \mathrm{~mm}$ and $1 \mathrm{~mm}$, Retsch). They were then surface etched with1M sodium hydroxide ( $\mathrm{NaOH}$, Merck, Darmstadt, Germany) at room temperature for $5 \pm 0.5$ minutes to obtain three composites having similar surface characteristics (MLD, MLDL and MDL, Table 1). The granules were then sterilized with ethylene oxide (IsoTron Nederland BV, Ede, the Netherlands). Sterile materials were then used for all the experiments described in this study.

Table 1. Design characteristics of the composites (all have apatite/polymer content ratio of $50 \%$ wt.).

\begin{tabular}{|c|c|c|}
\hline & $\begin{array}{l}\text { Polylactide monomer composition } \\
\text { [\%mol.] }\end{array}$ & $\begin{array}{l}\text { Inherent viscosity } \\
\text { Starting (declared) [dL g-1] } \\
\text { Expected in the composite }\left[\mathrm{dL} \mathrm{g}^{-1}\right]\end{array}$ \\
\hline MLD & 96 L-lactide / 4 D-lactide (copolymer) & $\begin{array}{l}5.67 \\
\sim 0.5 \\
\end{array}$ \\
\hline MLDL & 70 L-lactide / 30 D, L-lactide (copolymer) & $\begin{array}{l}3.85 \\
\sim 0.5 \\
\end{array}$ \\
\hline MDL & $\mathrm{D}$, L-lactide & $\begin{array}{l}4.02 \\
\sim 0.5\end{array}$ \\
\hline
\end{tabular}

To evaluate the changes occurring on the polymers caused by the extrusion, we also extruded them without apatite particles under the same conditions used for composites. In the case of composites, we firstly separated apatite particles from the polymer component through vacuum filtering with glass funnels (ROBU, Germany; borosilicate 3.3 with glass filter having porosity \#5) and PTFE membrane filter (Toyo Roshi Kaisha, Advantec, Japan; pore size $0.1 \mu \mathrm{m}$ ). Afterwards, we dissolved the supplied and the extruded polymers (i.e. with and without apatite) in chloroform (Sigma-Aldrich, Steinheim,Germany) at a concentration of $0.1 \mathrm{~g} \mathrm{dL}^{-1}$ and measured the relative viscosity $\left(\eta_{\text {rel }}\right)$ using an Ubbelohde (ASTM) viscometer (OC, PSLRheotek, Burnham on Crouch, United Kingdom) at $25 \pm 0.1^{\circ} \mathrm{C}$. From $\eta_{\text {rel }}$ we could determine the inherent $\left(\eta_{\text {inh }}\right)$ and intrinsic $(<\eta>)$ viscosities (according to SolomonCiută). ${ }^{[356]}$ By using Mark-Houwink equation, the weight average molecular weight $\left(M_{w}\right)$ of the polymers was calculated using the inherent viscosity, as follows: 


$$
\begin{aligned}
& \eta_{\text {rel }}=t_{\text {pol }} / t_{\text {Chlor }} \\
& \eta_{\text {sp }}=\eta_{\text {rel }}-1 \\
& \eta_{\text {inh }}=\ln \left(\eta_{\text {rel }}\right) / \hat{c} \\
& <\eta>=\left[\mathrm{sqrt}\left(2 \cdot\left(\eta_{\mathrm{sp}}-\ln \left(\eta_{\text {rel }}\right)\right)\right)\right] / \hat{c} \\
& \ln \left(\eta_{\text {inh }}\right)=\ln (K)+\bar{a} \cdot \ln \left(M_{\mathrm{w}}\right) \text { from which } M_{w}=\exp \left[\left(\ln \left(\eta_{\text {inh }}\right)-\ln (K)\right) / \bar{a}\right]
\end{aligned}
$$

where $t_{p o l}$ and $t_{c h l o r}$ are the measured time for the solution of polymer in chloroform and pure chloroform to flow in the viscometer respectively, $\hat{c}$ is the polymer concentration in chloroform, $K$ and $\bar{a}$ are the Mark-Houwink constants related to inherent viscosity (Table 2). The effective content by weight (\%wt.) of apatite and polymer in the extruded composites was determined by burning the polymer out from the composites in a sinter oven (C19, Nabertherm, Lilienthal, Germany) at $900 \pm 5^{\circ} \mathrm{C}$ for two hours. The bulk and surface chemistry of the composites were analysed with XRD and FTIR as described in \$6.2.1. Scanning electron microscopy (SEM) in secondary electron modality was performed on loose granules to evaluate their surface topography and apatite exposure.

Table 2. Mark-Houwink constants for the three polymers. They are constants valid when the measurements are done in chloroform at the initial concentration of $0.1 \mathrm{~g} \mathrm{dL}^{-1}$ and temperature $25^{\circ} \mathrm{C}$ and can be used to calculate the weight average molecular weight with inherent viscosity $\eta_{\text {inh. }}$. These values are provided by the polymer supplier. ${ }^{[37]}$ Please note that, as also confirmed by the supplier, since PLD has a content of L-lactide monomer near $100 \%$, its constants can be approximated to those typically used for poly(L-lactide).

\begin{tabular}{lll} 
& \multicolumn{3}{c}{ K } \\
& {$\left[\mathrm{dL} \mathrm{g} \mathrm{g}^{-1}\right]$} & $\bar{a}$ \\
\hline $\mathrm{PLD}$ & $4.7 \cdot 10^{-4}$ & 0.67 \\
\hline $\mathrm{PLDL}$ & $2.0 \cdot 10^{-4}$ & 0.73 \\
\hline $\mathrm{PDL}$ & $1.8 \cdot 10^{-4}$ & 0.72 \\
\hline
\end{tabular}

\subsubsection{Protein adsorption and fluid uptake from $0.1 \%$ FBS}

Sterile granules $(0.2 \mathrm{cc})$ of the composites and cylinders of the two tricalcium phosphate ceramics were weighed before use $\left(\mathrm{m}_{0}\right)$ and placed respectively in 2 and $3.8 \mathrm{~mL}$ of $0.1 \%$ foetal bovine serum (FBS, Invitrogen, Darmstadt, Germany) containing $0.0025 \% \mathrm{v}$. sodium azide to prevent bacterial infection (in triplicate). They were incubated at $37 \pm 0.5^{\circ} \mathrm{C}$ and $5 \% \mathrm{CO}_{2}$ for one week. Proteins adsorbed from FBS were measured after seven days using micro BCA assay kit (Pierce Biotechnology Inc., Rockford, IL, USA) and spectrophotometer (Anthos) with absorbance filter of $595 \mathrm{~nm}$. The serum protein adsorbed by the samples (expressed in $\mu \mathrm{g}$ per $\mathrm{cc}$ ) was estimated through a calibration serum proteins curve using FBS after determining the total proteins content in FBS (i.e. $33.78 \pm 0.64 \mathrm{mg} \mathrm{mL}^{-1}$ ). The granules and cylinders were then used to determine the uptake of serum. Excess fluid was carefully wiped away from the analyzed samples and their wet weight was 
measured ( $\left.m_{\text {wet }}\right)$. Afterwards, they have been vacuum-dried at $37 \pm 1^{\circ} \mathrm{C}$ until their weight was stable and then were weighed again $\left(m_{d r y}\right)$. The fluid uptake was determined as $100 \cdot\left(m_{\text {wet }}-m_{\text {dry }}\right) / m_{\text {dry }}$.

\subsubsection{Accelerated in vitro degradation of the composites}

Table 3 reports the $T_{g}$ of the polymers used in this study. Measurement of the changes in mass loss, fluid uptake and molecular weight are useful to analyse the degradation profile. In this study we used composites of polymers with nano-sized apatite particles, to evaluate the molecular weight changes we used Ubbelohde viscometer to determine the inherent and intrinsic viscosities $\left(\eta_{\text {inh }}\right.$ and $\left.\langle\eta\rangle\right)$. Then, with $\eta_{\text {inh }}$ we applied Mark-Houwink equation to calculate the weight average molecular weight $\left(\mathrm{M}_{\mathrm{w}}\right)$ as explained in $\$ 6.2 .3$.

Table 3. Glass transition temperature of the polymers used in this study as declared by the supplier.

\begin{tabular}{ll}
\hline & $\mathrm{T}_{g}$ \\
& {$\left[{ }^{\circ} \mathrm{C}\right]$} \\
\hline $\mathrm{PLD}$ & $60-65$ \\
\hline $\mathrm{PLDL}$ & $55-60$ \\
\hline $\mathrm{PDL}$ & $50-55$ \\
\hline
\end{tabular}

\subsubsection{Theory background}

Studying the in vitro/in vivo degradation/resorption of polylactide(s) for medical use is a common experiment, where samples are retrieved at certain time moments and evaluated regarding the change in some of their physicochemical (e.g. molecular weight, crystallinity and mass loss) and mechanical characteristics. Typically, in vitro tests mimic the physiological conditions (i.e. the samples are kept in simulated body solutions, such as phosphate buffered solution, at $37^{\circ} \mathrm{C}$ and periodical fluid refreshments are executed).[336, 388-391] However, the time for the complete degradation of polylactide(s) in physiological conditions has been reported exceeding five years in some cases. ${ }^{[387,}$, 392] This fact has large impact on the development of polylactde(s)-based products in an industrial context, which require cost-effective and time-saving reliable procedures. Thus, accelerated degradation studies by mean of various tricks such as increasing the $\mathrm{pH}^{[393]}$ and the temperature ${ }^{[354,356,394,395]}$ of the degrading fluid or applying ultrasounds ${ }^{[396]}$ have been proposed. So far, increasing the temperature of the degrading fluid has shown to be the most reliable method to model the (long-term) degradation behavior of polymer-based materials. ${ }^{[354]}$ However, it has been recommended that such tests, to be valid, should be performed at temperatures lower than the polymer glass transition temperature (i.e. $T_{g}$ ) to avoid undesired effects due to the polymer state transitions. ${ }^{[395]}$ However, this method should be carefully used. Here we will use the change in molecular weight to model the degradation of 
the polymer phase in composites considering the elevated temperature factor. Polylactide(s) are known to hydrolytically degrade ${ }^{[349,387]}$ and various linear models describing the relationship between molecular weight changes and temperature have been proposed. They all are based on the fact that the number average molecular weight $\left(\mathrm{M}_{\mathrm{n}}\right)$ is correlated with the cleavage of the polymer chains. A generally proposed linear model is ${ }^{[397]}$

$\left(1 / M_{n t}\right)=\left(1 / M_{n 0}\right)+k \cdot t$

where $M_{n t}$ is the number average molecular weight at the time point $t, M_{n 0}$ is the number average molecular weight before hydrolytic degradation and $k$ is the hydrolytic degradation rate constant. However, the above described model does not take into account the hydrolytic autocatalysis typical of polyesters, ${ }^{[349,387]}$ thus another model has been proposed. [398] This one is based on the kinetics of ester hydrolysis reaction and included the autocatalysis provoked by the carboxylic acid end residuals. This model is described as

$\mathrm{M}_{\mathrm{nt}}=\mathrm{M}_{\mathrm{n} 0} \cdot \mathrm{e}^{-(\mathrm{k} \cdot \mathrm{t})}$

where $k$ is the catalyzed hydrolytic degradation rate constant. If this relationship holds true, a linear relationship between $\ln \left(\mathrm{M}_{\mathrm{nt}}\right)$ versus time should exist until the complete mass loss. However, since in our studies it is not possible to use GPC to estimate $M_{n}$, we can use the intrinsic viscosity $\langle\eta\rangle$ (measured with Ubbelohde viscometer) to estimate the catalyzed hydrolytic degradation rate constant. Based on Mark-Houwink equation, intrinsic viscosity is related to the viscosity average molecular weight $\mathrm{M}_{\mathrm{v}}$, which is close to the weight average molecular weight $\mathrm{M}_{\mathrm{w}}$. In turn, $M_{w}$ is usually proportional to $M_{n}$ and thus, by assuming that $M_{v}$ is also proportional to $M_{n}$, equation (1) can be rewritten as

$\left\langle\eta_{t}\right\rangle=\left\langle\eta_{0}>\cdot e^{-(k \cdot t)}\right.$

from which

$\ln \left(\left\langle\eta_{1}\right\rangle \mid\left\langle\eta_{0}\right\rangle\right)=-\mathrm{k} \cdot \mathrm{t}$

where $\left\langle\eta_{1}\right\rangle$ and $\left\langle\eta_{0}\right\rangle$ are the intrinsic viscosities at the time point $t$ and before degradation respectively. Linear regression of the plot $\ln \left(\left\langle\eta_{t}\right\rangle \mid\left\langle\eta_{0}\right\rangle\right)$ versus time $t$ will indicate the catalyzed hydrolytic degradation rate constant $k$. Large absolute values of $k$ indicate that (catalysed) hydrolysis of the polymer is faster.

\subsubsection{Experimental settings}

A phosphate buffered saline (PBS; Invitrogen, Darmstadt, Germany) solution having initial pH of $7.5 \pm 0.05$ was used. Sterile granules of each composite $(75 \pm 0.5 \mathrm{mg})$ were weighed before use $\left(\mathrm{m}_{0}\right)$ and soaked in $30 \mathrm{~mL}$ PBS at $55 \pm 0.5^{\circ} \mathrm{C}$ for five weeks. The temperature was set referring to the polymers $\mathrm{T}_{\mathrm{g}}$ reported in Table 3 . For each of the three time points considered, i.e. 1, 3 and 5 weeks, three samples of each material 
were used. Every day the $\mathrm{pH}$ of the degrading solution was recorded with a $\mathrm{pH}-$ meter (Orion 4 Star, Thermo Scientific, USA) and the medium was refreshed in case the $\mathrm{pH}$ fell below 7 . With the solution removed at every refreshment, the amounts (in $\mathrm{mg}$ ) of calcium and phosphate ions released from the samples were measured using appropriate biochemical kits (QuantiChrom ${ }^{\mathrm{TM}}$ Calcium assay kit, BioAssay Systems, USA; PhosphoWorks ${ }^{\mathrm{TM}}$ Colorimetric Phosphate Assay kit Blue Color, Bioquest Inc, USA) with the help of a spectrophotometer (AnthosZenyth 3100, Anthos Labtec Instruments $\mathrm{GmbH}$, Salzburg, Austria) and absorbance filter of $620 \mathrm{~nm}$ for both assays. At each of the considered time points, i.e. 1, 3 and 5 weeks, the granules were removed from the degrading media, the excess PBS was wiped away and their wet weight was measured $\left(m_{\text {wet }}\right)$. Afterwards they have been vacuum-dried at room temperature until their weight was stable and then were weighed $\left(m_{\text {dry }}\right)$. The mass loss and fluid uptake of the composites was determined as:

mass loss $=100 \cdot\left(m_{0}-m_{\text {dry }}\right) / m_{0}$

fluid uptake $=100 \cdot\left(m_{\text {wet }}-m_{\text {dry }}\right) / m_{\text {dry }}$

Part of the degraded samples were then heated at $900^{\circ} \mathrm{C}$ to burn the polymer phase out and determine the final effective apatite and polymer contents. The remaining part of the samples was dissolved in chloroform (Sigma-Aldrich) and, after separating apatite from the polymer, we determined the inherent and intrinsic viscosities $\left(\eta_{\text {inh }}\right.$ and $\langle\eta\rangle$ ) and weight average molecular weight $\left(\mathrm{M}_{\mathrm{w}}\right)$ using an Ubbelohde viscometer as explained in §6.2.3. To evaluate the hydrolysis rate of the polymer phase in the two composites we estimated the autocatalysed hydrolytic degradation rate constant $k$ as (see $\$ 6.2 .5 .1$. for theory background):

$\mathrm{k} \cdot \mathrm{t}=-\ln \left(\left\langle\eta_{\mathrm{t}}\right\rangle \mid\left\langle\eta_{0}\right\rangle\right)$

where $\left\langle\eta_{0}\right\rangle$ is the initial intrinsic viscosity and $\left\langle\eta_{1}\right\rangle$ is the intrinsic viscosity at the considered time point $t(t=0,7,21$ and 35 days) for the considered polymer phase. The results were plotted on a graph $\ln \left(\left\langle\eta_{1}\right\rangle \mid\left\langle\eta_{0}\right\rangle\right)$ against time $t$ (in days) and the constant $k$ was estimated with linear regression.

\subsubsection{Surface mineralization in simulated body fluid}

Simulated body fluid (SBF) was prepared according to Kokubo[247] by dissolving reagent grade chemicals (Merck) in distilled water strictly in the following order: $\mathrm{NaCl}$, $\mathrm{NaHCO}_{3}, \mathrm{KCl}, \mathrm{K}_{2} \mathrm{HPO}_{4} \cdot 3 \mathrm{H}_{2} \mathrm{O}, \mathrm{MgCl}_{2} \cdot 6 \mathrm{H}_{2} \mathrm{O}, \mathrm{CaCl}_{2}$ (calcium ion standard solution 0.1 $\mathrm{M}$, Metrohm, Herisau, Switzerland) and $\mathrm{Na}_{2} \mathrm{SO}_{4}$. The fluid was then buffered to $\mathrm{pH} 7.4$ at $36.5^{\circ} \mathrm{C}$ using Tris $\left(\left(\mathrm{CH}_{2} \mathrm{OH}\right)_{3} \mathrm{CNH}_{3}\right)$ and $1 \mathrm{M} \mathrm{HCl}$. The final solution had an ion concentration (in mM) as follows: $\mathrm{Na}^{+}, 142 ; \mathrm{K}^{+}, 5 ; \mathrm{Mg}^{2+}, 1.5 ; \mathrm{Ca}^{2+}, 2.5 ; \mathrm{Cl}^{-}, 147.8$; $\left(\mathrm{HCO}_{3}\right)^{-}, 4.2 ;\left(\mathrm{HPO}_{4}\right)^{2-}, 1 ;\left(\mathrm{SO}_{4}\right)^{2-}, 0.5$. Granules of the composites $(0.25 \mathrm{~g})$ and ceramics $(0.25 \mathrm{~g}$, prepared by crushing and sieving the cylinders) were soaked in 100 
$\mathrm{mL} \mathrm{SBF}$ (in triplicate) at $37 \pm 1^{\circ} \mathrm{C}$ for two days. The granules were then removed from $\mathrm{SBF}$, carefully rinsed with distilled water, dried, gold-sputtered and observed with SEM in secondary electron modality.

\subsubsection{Animal experiments}

With the permission of the local animal care committee (Animal Center, Sichuan University, Chengdu, China; protocol \#P11029), granules of the three composites (1 cc) and cylinders of the two tricalcium phosphate ceramics were implanted in the dorsal muscles of five sheep (female, 2-3 years old) for six months. Surgeries were performed under general anaesthesia (Isoflurane, Merck, Darmstadt, Germany; $2 \%$ in oxygen, oxygen flow rate of $4 \mathrm{~L} \mathrm{~min}^{-1}$ ) and sterile conditions. The muscles were exposed by longitudinal skin incisions and two lines of independent muscle pockets were created by blunt dissection and the samples were inserted. The pockets were then closed individually with non-resorbable suture material and the wound was closed using silk sutures. Six months after implantation, the animals were sacrificed with a lethal injection of pentobarbital (Vetanarcol ${ }^{\circledR}$, Merck; $60 \mathrm{mg} \mathrm{kg}^{-1}$ ). The samples were harvested with surrounding tissues and fixed in $4 \%$ buffered formaldehyde solution $(\mathrm{pH}=7.4)$ at $4^{\circ} \mathrm{C}$ for one week. After rinsing with phosphate buffer saline (PBS, Invitrogen), the samples were trimmed from surrounding soft tissues. Then the samples were dehydrated in a series of ethanol solutions $(70 \%, 80 \%, 90 \%, 95 \%$ and $100 \% \times 2$ ) and embedded in methyl metacrylate (MMA, LTI Nederland, the Netherlands). Non-decalcified histological sections (10-20 $\mu \mathrm{m}$ thick) were made using a diamond saw microtome (Leica SP1600, Leica Microsystems, Germany). Sections for light microscopy observations were stained with $1 \%$ methylene blue (Sigma-Aldrich) and $0.3 \%$ basic fuchsin (Sigma-Aldrich) solutions

The stained sections were scanned using a slide scanner (Dimage Scan Elite 5400Il, Konica Minolta Photo Imaging Inc, Tokyo, Japan) to obtain low magnification images for histomorphometric analysis. The sections were observed with a light microscope (Nikon Eclipse E200, Tokyo, Japan) to analyse the tissue reaction and bone formation. Histomorphometry was performed using Adobe Photoshop Elements 4.0 software. Firstly the whole sample was selected as a region of interest and the corresponding number of pixels was read as ROI. Then the material and mineralized bone were pseudo-coloured, and their respective pixels were counted as $M$ and $B$ respectively. The percentage of bone in the available space of the explants $\left(B_{p}\right)$ was then determined as $\mathrm{B}_{\mathrm{p}}=\mathrm{B} \cdot 100 /(\mathrm{ROI}-\mathrm{M})$. 


\subsubsection{Statistical analysis}

Two tail t-test (for populations with different variance) and post-hoc Tamhane ANOVA test were used to evaluate differences in the results. The choice between the two tests relied on the size of the compared data: if the data populations to be compared were two, t-test was use. If populations were more, ANOVA was used. A p-value lower than 0.05 was considered as significant difference in both statistical tests. The analyses were performed using Origin software (v8.0773, OriginPro, Northampton, MA, USA).

\subsection{Results}

\subsubsection{Tricalcium phosphate ceramics}

X-ray diffractometry (XRD) showed typical tricalcium phosphate (>99\% pure TCP phase, $<1 \%$ hydroxyapatite phase) patterns for both TCPS and TCPB (Figure 1a). At the same time, the absence of extra-peaks infrared spectroscopy (FTIR) indicated that no impurity was present in the two ceramics (Figure 1b). Scanning electron microscopy (SEM) demonstrated that both ceramics have micro-structured surfaces with micro-porosity (Figure 2). Measurements showed that TCPS presented significantly smaller grains as compared to TCPB, while it also had significant smaller micro-pore size (Figure 2; Table 4). Consistently with the previous measurements, mercury intrusion measurements indicated that the specific surface area was larger for TCPS than TCPB. Further, it showed that the overall porosity (i.e. macroand micro-) of the two ceramics was similar (Table 4). When placed in SPS solution for eight hours, by virtue of its larger surface area TCPS could dissolve quicker than TCPB releasing significant more calcium ions (Figure 3, Table 4).

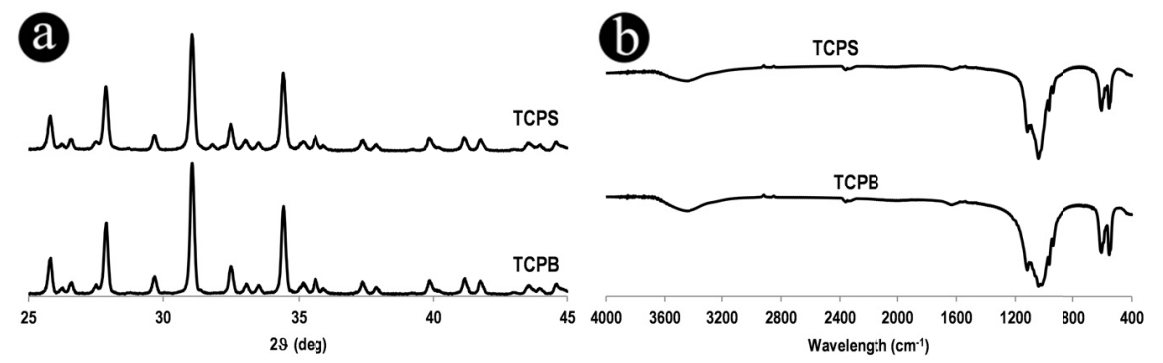

Figure 1. (a) XRD and (b) FTIR patterns for the two tricalcium phosphate ceramics.

\subsubsection{Characterization of apatite}

Similarly to what was reported in previous Chapters in this thesis, $\mathrm{X}$-ray diffraction (XRD) and Fourier transform infra-red spectrometry (FTIR) showed that the synthesized powder is a calcium phosphate apatite (Figure 4a,b). Needle-like apatite particles having $300-400 \mathrm{~nm}$ length and $20-40 \mathrm{~nm}$ width were seen with TEM (Figure 
4c). As already observed in other Chapters of this work, the shape and size are similar to those of needle-like apatite observed in human cortical bone.[23]

Table 4. Summary of the surface characteristics of the two ceramics. Statistical comparison is expressed as $p$-value (t-test) only for those properties measured in-house (i.e. grain and pore size). Porosity and surface area were measured outsourced (i.e. mercury intrusion) and only one measurement per sample is available.

\begin{tabular}{llllll}
\hline & $\begin{array}{l}\text { Grain size } \\
{[\mu \mathrm{m}]}\end{array}$ & $\begin{array}{l}\text { Pore size } \\
{[\mu \mathrm{m}]}\end{array}$ & $\begin{array}{l}\text { Porosity } \\
{[\%]}\end{array}$ & $\begin{array}{l}\text { Specific surface area } \\
{\left[\mathrm{m}^{2} \mathrm{~g}^{-1}\right]}\end{array}$ & $\begin{array}{l}\text { Calcium released }(8 \mathrm{hrs}) \\
{[\mathrm{ppm}]}\end{array}$ \\
\hline TCPB & $3.0 \pm 0.5$ & $1.6 \pm 0.6$ & 72 & 0.77 & $9.0 \pm 0.4$ \\
\hline TCPS & $0.9 \pm 0.2$ & $0.6 \pm 0.2$ & 70 & 1.48 & $12.2 \pm 0.8$ \\
\hline p, t-test & $<10^{-5}$ & $<10^{-4}$ & n/a & n/a & $<0.01$ \\
\hline
\end{tabular}
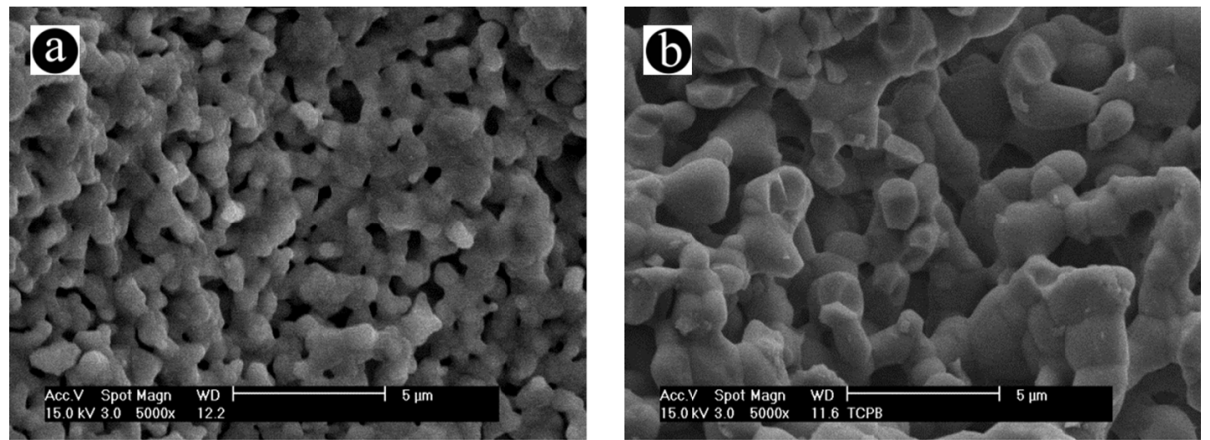

Figure 2. SEM images of (a) TCPS and (b) TCPB showing that their surface have different microstructures and grain sizes.

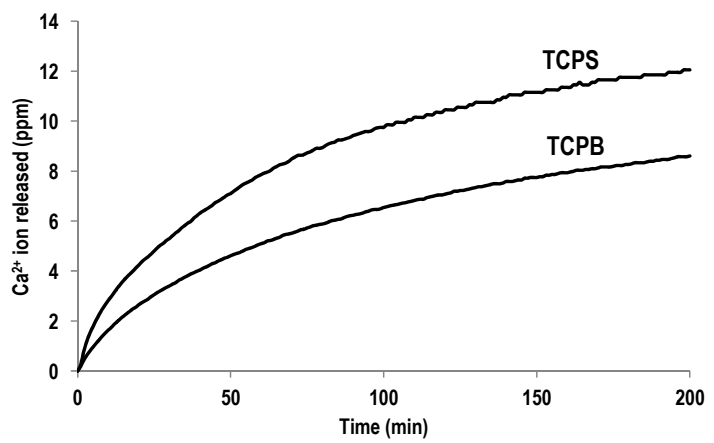

Figure 3. Eight-hour continuous measurement of calcium ion concentration in SPS when it contained samples of TCPS and TCPB. 

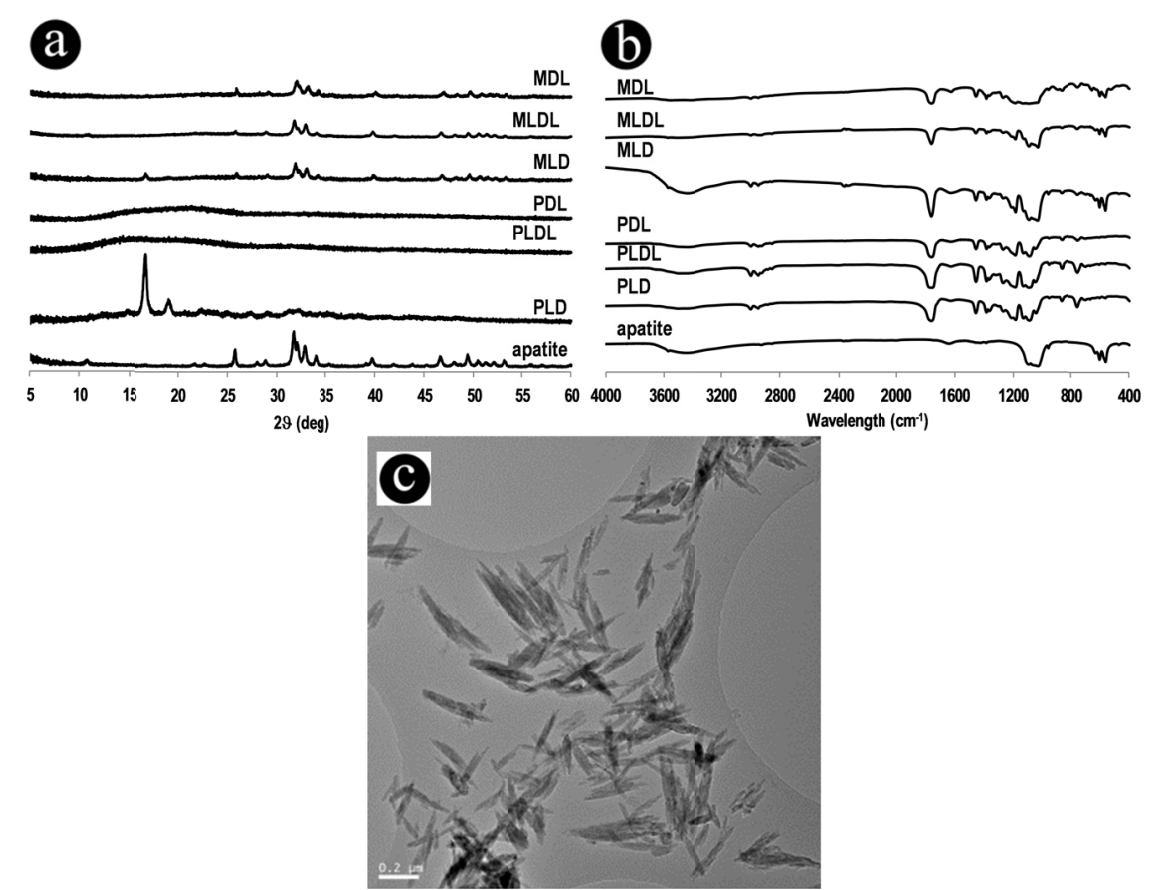

Figure 4. (a) XRD and (b) FTIR spectra for not-sintered apatite, polymer and composites. (c) TEM picture of the not-sintered apatite, which was used to make the composites.

\subsubsection{Characterization of composites}

The composites were prepared by extruding three polymers with calcium phosphate apatite particles. XRD (Figure 4a), together with FTIR, demonstrated that the composites are bi-phasic materials composed of apatite and the polymer. This is particularly clear with FTIR, where all vibrational bands of the polymers and apatite are visible in the patterns of the composites (Figure $4 b$ ). Further to this, FTIR indicated that surface treatment had no effect on the surface chemistry as the composite spectra did not show any additional phase than apatite and polymers (Figure 4b). After burning the polymer out, the CaP content of the three composites was similar (Table 6). SEM observations showed that the surface of the three composites was similar, with exposed apatite particles that generated fairly uniform nano-structured surfaces (Figure 5). Large effects of extrusion on the inherent viscosity of the polymer phases were seen. In particular, when the polymer alone was extruded, there was a large decrease of about $50 \%$, whereas if the polymer was extruded with apatite particles the viscosity decreased about ten times (Table 5). It is interesting that the (calculated) weight average molecular weight of the polymer phase in the three composites were very similar to each other (Table 5). Despite statistical tests showed significant differences, these molecular weights were very low 
and had minimal differences $( \pm 6 \mathrm{kDa})$ and thus, in practical terms, they may be considered similar to each other.
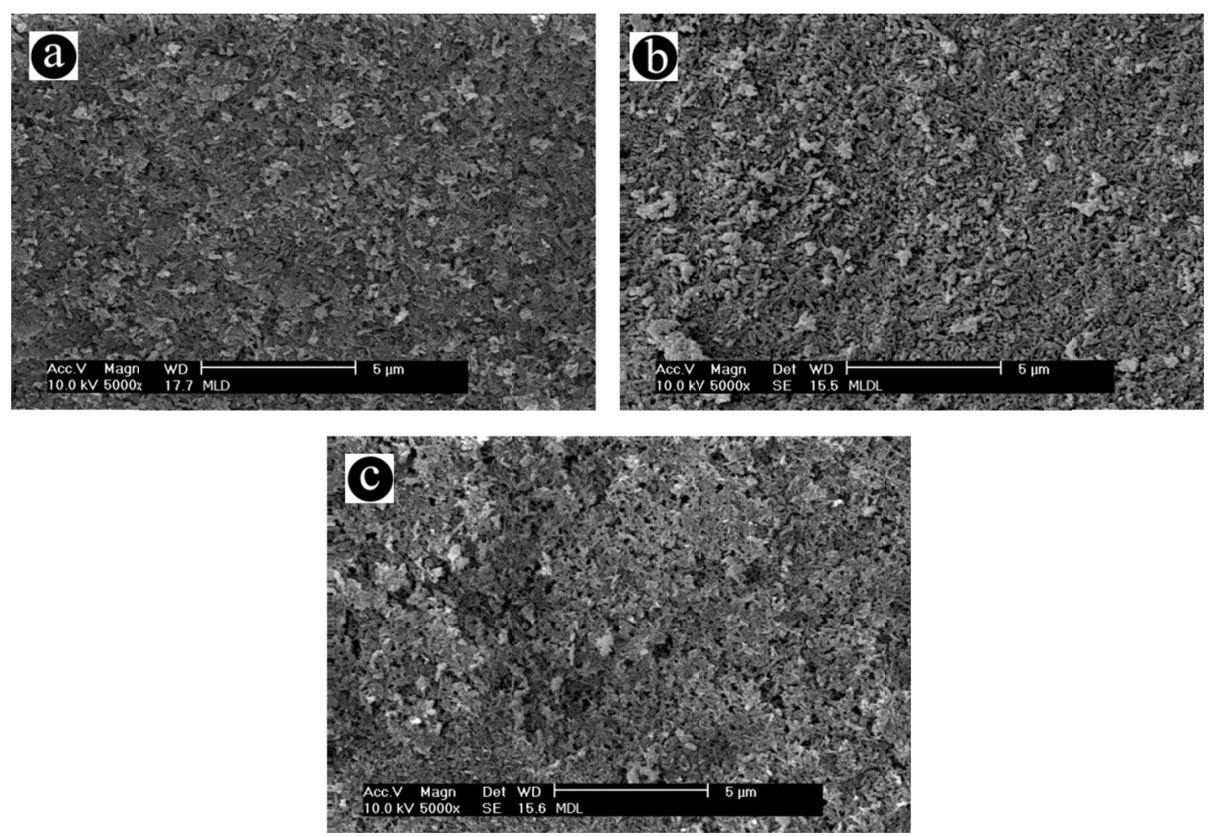

Figure 5. SEM images showing the surface of (a) MLD, (b) MLDL and (c) MDL composite granules.

Table 5. Ubbelohde measurements of inherent ( $\left.\eta_{\text {inh }}\right)$ and intrinsic $(<\eta>)$ viscosity, and calculated weight average molecular weight $\left(\mathrm{M}_{\mathrm{w}}\right)$ for the polymers as supplied and after extrusion without and with apatite particles in the content ratio of 50/50 to make the composites. Statistical comparison is expressed in terms of $p$-values.

\begin{tabular}{|c|c|c|c|}
\hline & $\begin{array}{l}\text { As supplied } \\
\eta_{\text {inh }}\left[\mathrm{dL} \mathrm{g}^{-1}\right] \\
<\eta>\left[\mathrm{dL} \mathrm{g}^{-1}\right] \\
M_{w}[\mathrm{kDa}]\end{array}$ & $\begin{array}{l}\text { Extruded alone } \\
\eta_{\text {inh }}\left[\mathrm{dL} \mathrm{g}^{-1}\right] \\
<\eta>\left[\mathrm{dL} \mathrm{g} \mathrm{g}^{-1}\right] \\
M_{\mathrm{w}}[\mathrm{kDa}]\end{array}$ & $\begin{array}{l}\text { Extruded with apatite } \\
\eta_{\text {inh }}\left[\mathrm{dL} \mathrm{g}^{-1}\right] \\
<\eta>\left[\mathrm{dL} \mathrm{g}^{-1}\right] \\
\mathrm{M}_{\mathrm{w}}[\mathrm{kDa}]\end{array}$ \\
\hline & $6.01 \pm 0.01$ & $3.01 \pm 0.01$ & $0.60 \pm 0.01$ \\
\hline PLD & $\begin{array}{l}6.17 \pm 0.02 \\
1350 \pm 2\end{array}$ & $\begin{array}{l}3.05 \pm 0.01 \\
481 \pm 2\end{array}$ & $\begin{array}{l}0.61 \pm 0.01 \\
43.5 \pm 0.9\end{array}$ \\
\hline PLDL & $\begin{array}{l}3.81 \pm 0.02 \\
3.87 \pm 0.02 \\
728 \pm 2 \\
\end{array}$ & $\begin{array}{l}1.99 \pm 0.01 \\
2.01 \pm 0.02 \\
300 \pm 3\end{array}$ & $\begin{array}{l}0.48 \pm 0.01 \\
0.49 \pm 0.01 \\
42.9 \pm 0.9 \\
\end{array}$ \\
\hline PDL & $\begin{array}{l}3.40 \pm 0.01 \\
3.45 \pm 0.02 \\
871 \pm 5\end{array}$ & $\begin{array}{l}1.35 \pm 0.02 \\
1.36 \pm 0.02 \\
242 \pm 5\end{array}$ & $\begin{array}{l}0.44 \pm 0.01 \\
0.45 \pm 0.02 \\
51.5 \pm 1.4\end{array}$ \\
\hline $\begin{array}{l}\text { p, ANOVA }\left(M_{w}\right) \\
\text { PLD-PLDL } \\
\text { PLD-PDL } \\
\text { PDL-PLDL }\end{array}$ & $\begin{array}{l}<10^{-4} \\
<10^{-3} \\
<10^{-3}\end{array}$ & $\begin{array}{l}<10^{-3} \\
<10^{-3} \\
<10^{-3}\end{array}$ & $\begin{array}{l}>0.1 \text { (no) } \\
<0.02 \\
<0.03\end{array}$ \\
\hline
\end{tabular}


Table 6. Burn test results on the composites as prepared and during the accelerated in vitro degradation. Results are reported in terms of apatite content (\%wt.) in the burnt composites. Statistical comparison is expressed in terms of $p$-values comparing the three materials.

\begin{tabular}{lllll}
\hline & $\begin{array}{l}\text { As prepared } \\
\text { [\%wt.] }\end{array}$ & $\begin{array}{l}\text { 1 week } \\
{[\% \text { wt.] }}\end{array}$ & $\begin{array}{l}3 \text { weeks } \\
{[\% w t .]}\end{array}$ & $\begin{array}{l}5 \text { weeks } \\
{[\% w t .]}\end{array}$ \\
\hline MLD & $48.5 \pm 0.5$ & $48.9 \pm 0.4$ & $47.7 \pm 0.3$ & $45.6 \pm 0.6$ \\
\hline MLDL & $51.6 \pm 0.6$ & $47.8 \pm 0.5$ & $42.8 \pm 0.5$ & $37.7 \pm 0.4$ \\
\hline MDL & $49.1 \pm 0.1$ & $49.9 \pm 0.6$ & $42.8 \pm 0.4$ & $28.8 \pm 0.4$ \\
\hline p, ANOVA & & & & \\
MLD-MLDL & $>0.65$ & $>0.52$ & $<10^{-3}$ & $<10^{-3}$ \\
MLD-MDL & $>0.71$ & 0.70 & $<10^{-3}$ & $<10^{-5}$ \\
MLDL-MDL & $>0.53$ & $>0.58$ & 0.93 & $<10^{-3}$ \\
\hline
\end{tabular}

\subsubsection{Protein adsorption studies}

After one week no significant differences in fluid uptake and protein adsorption was seen between MLDL and MDL. However, these two composites could absorb significantly more fluids and adsorb more proteins than MLD (Figure 6a,b, Table 7). The ceramic having smaller grain size, i.e. TCPS, could uptake significantly more fluids than TCPB (t-test, $p<0.011$ ) (Figure $6 \mathrm{~d}$ ). The adsorption of serum proteins was significantly higher on TCPS than TCPB (t-test, $p<0.015$ ) (Figures 6$)$. In general, we could observe a 'direct' correlation between protein adsorption and fluid uptake, which was seen for both kinds of biomaterials (i.e. composites and ceramics).
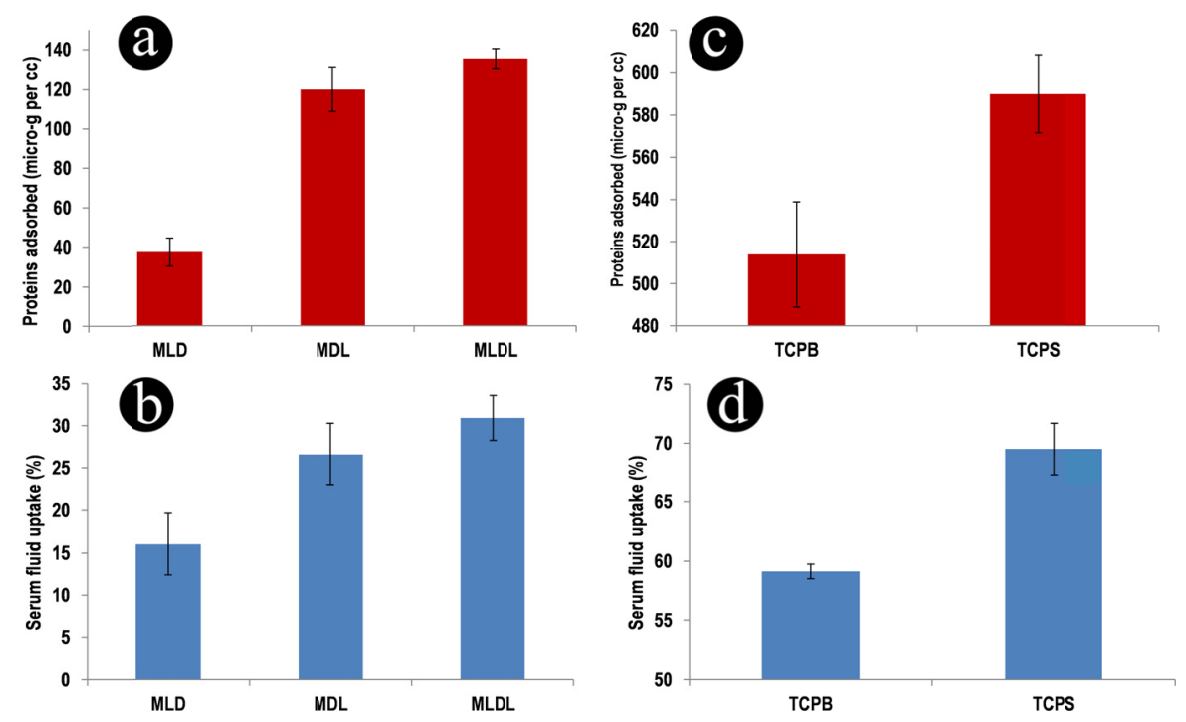

Figure 6. Adsorption of proteins after one week in $0.1 \%$ FBS solution.(a) Serum protein adsorption and (b) serum fluid uptake of the three composites. (c) Serum protein adsorption and (d) serum fluid uptake of the ceramics. Statistical comparison is expressed in terms of $p$-values and is reported in the text and in Table 7. 
Table 7. Statistical comparison of serum protein adsorption and fluid uptake after seven days in $0.1 \%$ FBS. The test used was one-way ANOVA test for means (Tukey's) where a p-value smaller than 0.05 was considered as significant difference.

\begin{tabular}{lll}
\hline & Serum protein adsorption & Fluid uptake \\
\hline MLD-MLDL & $10^{-4}$ & $10^{-3}$ \\
MLD-MDL & $10^{-4}$ & $<0.02$ \\
MLDL-MDL & $>0.6(\mathrm{no})$ & $>0.7(\mathrm{no})$ \\
\hline
\end{tabular}

\subsubsection{Accelerated in vitro degradation of the composites}

Samples containing poly(D,L-lactide), i.e. MDL, could not be retrieved after five weeks as they broke down and fully fragmented. These samples had more swollen volume than MLD and MLDL after three weeks and could hardly keep their shape when touched with normal laboratory stainless steel spoons or tweezers. This indicated that MDL composites degraded and absorbed fluids faster. However, all three composites degraded during the 5-week period as indicated by their mass loss (Figure 7a), continuous release of calcium and phosphate ions (Figure 8). We observed that the apatite phase content decreased compared to the starting conditions (Table 6). In particular, samples containing PLD had the most stable mass, whereas MDL degraded most. Consistently, there was a direct link between mass loss and fluid uptake (Figure $7 \mathrm{~b}$ ), where the larger mass loss corresponded to a large fluid uptake and vice versa. A fast decline in intrinsic viscosity (and weight average molecular weight) was observed in MDL composites, followed by MLDL and MDL (Table 8). The degradation rate constants and the correlation coefficients are in Figure 9 . The validity of the model to estimate the autocatalytic degradation rate is supported by the high values of the correlation coefficients. The results show that the polymer phase in MDL had a faster autocatalysed hydrolysis than MLDL and MDL, and in particular, this last result is in line with the fluid absorption trends confirming the important role fluid uptake has in degrading the polymer phase.

Table 8. Measured inherent ( $\left.\eta_{\text {inh }}\right)$ and intrinsic $(\langle\eta>)$ viscosity, and weight average molecular weight $\left(\mathrm{M}_{\mathrm{w}}\right)$ of the polymer phase over five weeks in PBS at $55^{\circ} \mathrm{C}$.

\begin{tabular}{|c|c|c|c|c|}
\hline & $\begin{array}{l}0 \text { weeks } \\
\eta_{\text {inh }}\left[\mathrm{dL} \mathrm{g}^{-1}\right] \\
<\eta>\left[\mathrm{dL} \mathrm{g}^{-1}\right] \\
M_{w}[\mathrm{kDa}]\end{array}$ & $\begin{array}{l}1 \text { week } \\
\eta_{\text {inh }}\left[\mathrm{dL} \mathrm{g}^{-1}\right] \\
<\eta>\left[\mathrm{dL} \mathrm{g}^{-1}\right] \\
M_{w}[\mathrm{kDa}]\end{array}$ & $\begin{array}{l}3 \text { weeks } \\
\eta_{\text {inh }}\left[\mathrm{dL} \mathrm{g}^{-1}\right] \\
<\eta>\left[\mathrm{dL} \mathrm{g}^{-1}\right] \\
M_{w}[\mathrm{kDa}]\end{array}$ & $\begin{array}{l}5 \text { weeks } \\
\eta_{\text {inh }}\left[\mathrm{dL} \mathrm{g}^{-1}\right] \\
<\eta>\left[\mathrm{dL} \mathrm{g}^{-1}\right] \\
M_{w}[\mathrm{kDa}]\end{array}$ \\
\hline & $0.60 \pm 0.01$ & $0.51 \pm 0.03$ & $0.36 \pm 0.02$ & $0.32 \pm 0.01$ \\
\hline MLD & $\begin{array}{l}0.61 \pm 0.01 \\
43.5 \pm 0.9\end{array}$ & $\begin{array}{l}0.52 \pm 0.02 \\
34.5 \pm 1.7\end{array}$ & $\begin{array}{l}0.36 \pm 0.01 \\
20.4 \pm 0.6\end{array}$ & $\begin{array}{l}0.33 \pm 0.01 \\
16.9 \pm 0.5\end{array}$ \\
\hline MLDL & $\begin{array}{l}0.48 \pm 0.01 \\
0.49 \pm 0.01 \\
42.9 \pm 0.9\end{array}$ & $\begin{array}{l}0.30 \pm 0.02 \\
0.30 \pm 0.01 \\
22.7 \pm 0.3\end{array}$ & $\begin{array}{l}0.23 \pm 0.01 \\
0.24 \pm 0.02 \\
16.1 \pm 0.7\end{array}$ & $\begin{array}{l}0.14 \pm 0.02 \\
0.15 \pm 0.01 \\
8.8 \pm 0.3\end{array}$ \\
\hline MDL & $\begin{array}{l}0.44 \pm 0.01 \\
0.45 \pm 0.02 \\
51.5 \pm 1.4\end{array}$ & $\begin{array}{l}0.20 \pm 0.01 \\
0.20 \pm 0.01 \\
17.5 \pm 1.1\end{array}$ & $\begin{array}{l}0.10 \pm 0.02 \\
0.11 \pm 0.01 \\
7.3 \pm 0.8\end{array}$ & not measured \\
\hline
\end{tabular}



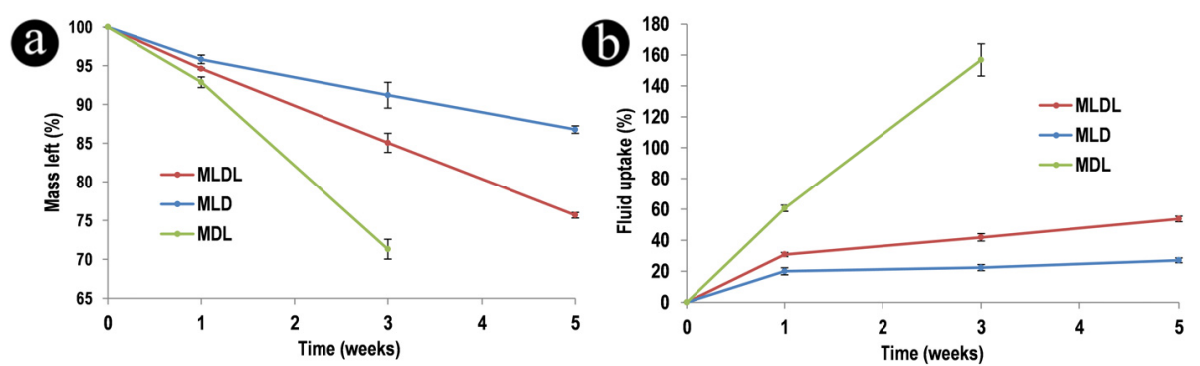

Figure 7. Mass left (a) and fluid uptake (b) of the three composites over five weeks accelerated degradation at 55C. Differences are all significative.
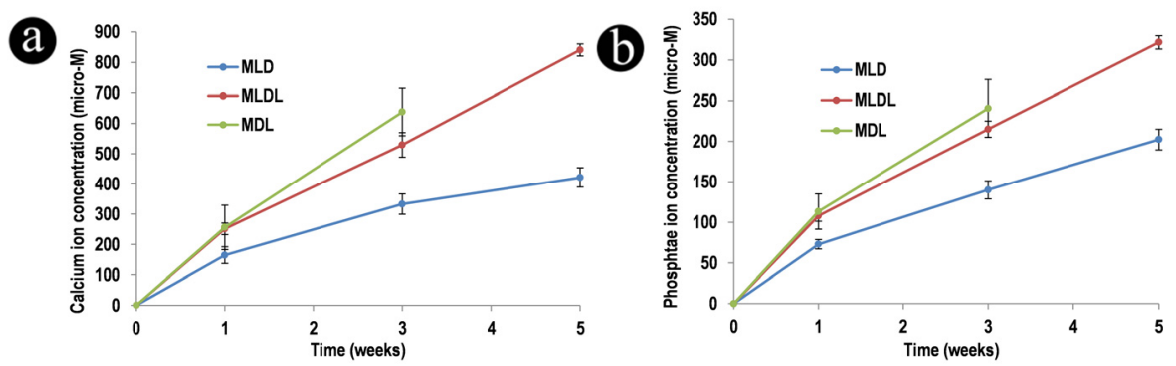

Figure 8. (a) Calcium and (b) phosphate cumulative ion concentration over 5 weeks in PBS.

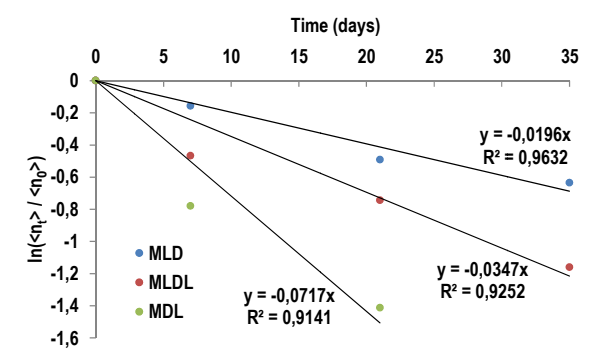

Figure 9. Autocatalysed hydrolytic degradation rate constant $k$ obtained by linearly regressing the plot of $\ln \left(\left\langle\eta_{1}\right\rangle \mid\left\langle\eta_{0}\right\rangle\right)$ against time. The (absolute) rate constants resulted 0.0196 day $^{-1}, 0.0347$ day $^{-1}$ and 0.0717 day $^{-1}$ for the polymer phases in MLD, MLDL and MDL respectively, indicating faster autocatalysed hydrolysis for the polymer in MDL. The correlation coefficients $R^{2}$ indicate the model is valid in this experiment.

\subsubsection{Surface mineralization}

After immersion in SBF, both ceramics (Figure 10) and all the composites (Figure 11) showed surface mineralisation within two days as indicated by the formation of layers with irregular shaped globules where apatite had spontaneously nucleated. It is interesting that, after mineralisation, the materials presented more nano-structured surface textures than their starting counterparts. In the case of ceramics, it can be observed that the precipitated apatite formed globules, which apparently still maintained the initial difference between TCPS and TCPB in their grain size. 

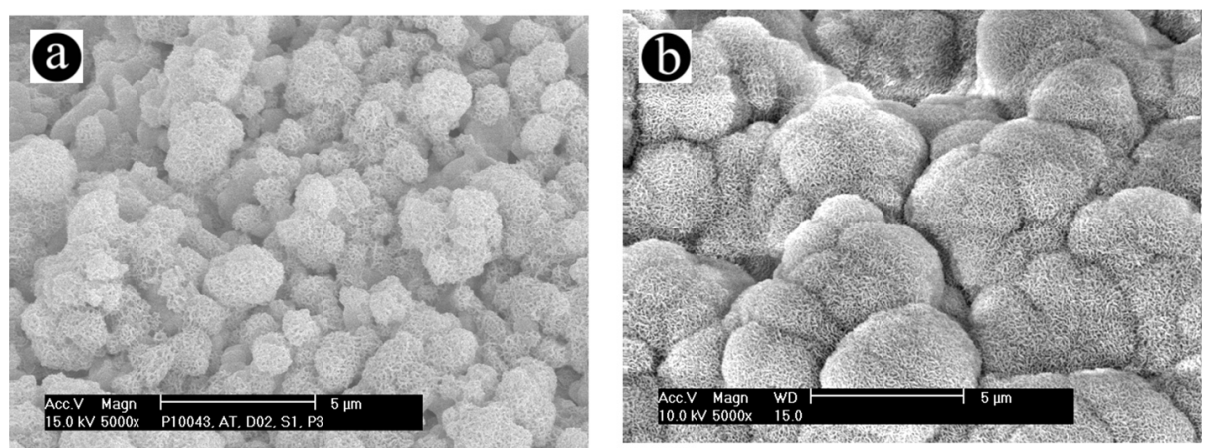

Figure 10. SEM images of (a) TCPS and (b) TCPB after two days in SBF.
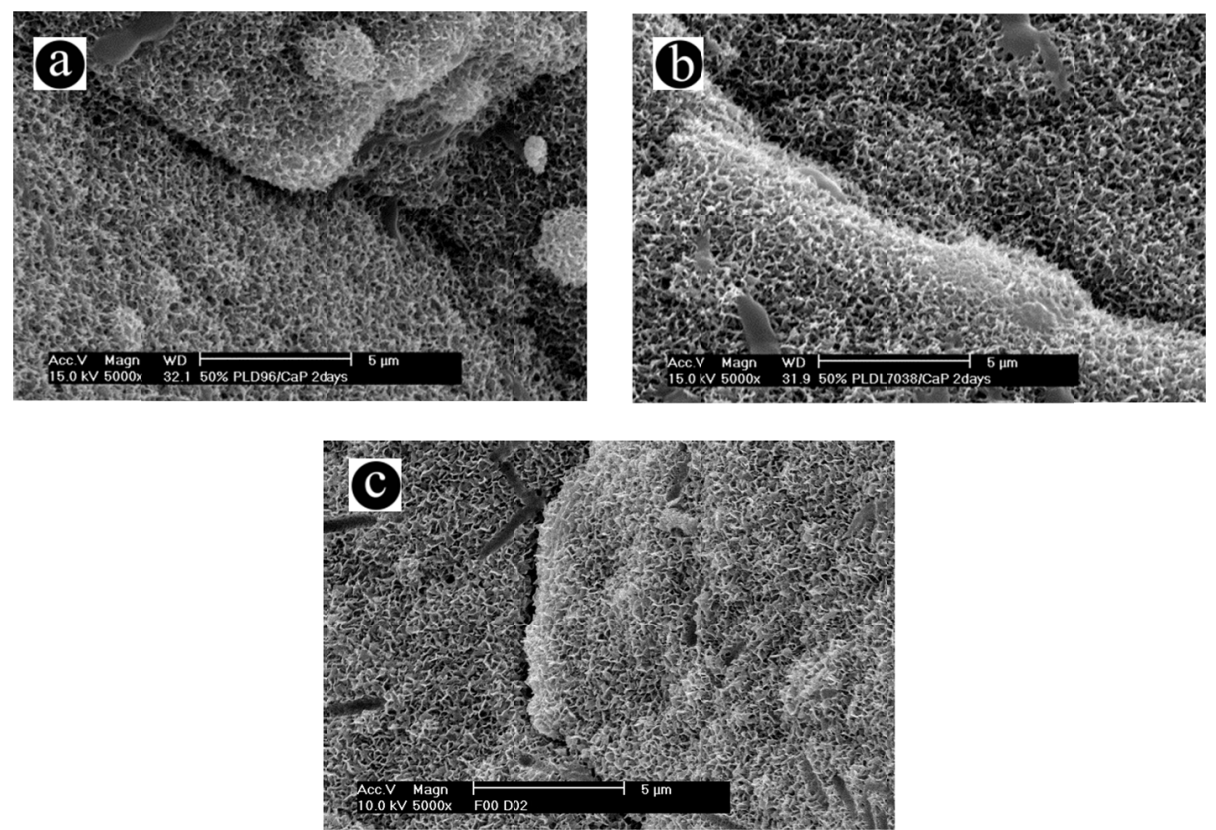

Figure 11. SEM images of (a) MDL and (b) MLDL and (c) MDL after two days in SBF.

\subsubsection{Animal experiments}

A total of five samples per material were intramuscularly implanted in five sheep. After six months, all samples were retrieved and they were surrounded by a thin layer of connective tissue and then muscle tissue. As shown in the histological overviews (Figure 12a), morphologically, it appeared that all MLD specimens retained the initial shape and size of the granules indicating that MLD degraded much slower than the other two composites. Its explants presented granules compacted with each other and little free available space filled with soft tissues and no bone formed in any MLD explant (Table 9). High magnification images (Figure 13) showed that MLD granules 
presented non-degraded bulks surrounded by few thin layers of mineralized surface. On the contrary, the core of all MDL and MLDL implants had areas of bone formation (Figure 12b,c, Table 9) and it appeared that the granules were shifted towards the edges by the formed bone. However, it appears that MDL had smaller granule size and larger available space filled with soft tissue than MLDL. These observations indicates that MDL may have degraded in vivo quicker than MLDL. Microscopy images (Figure 13) showed that bone had formed tightly on the surface of the granules in both MDL and MLDL. Active osteoblasts were present on the outer surface of the newly formed bone (Figure 13), indicating that there was still active bone formation after six months of implantation. At the same time, osteocytes were observed within lacunae in the mineralized mature bone. In MDL and MLDL composites the granules had degraded as demonstrated by numerous crossing cracks. Interestingly, thick mineralized layers surrounding the granules were observed in both MDL and MLDL, on which bone was tightly deposited. Histomorphometry results demonstrated that MLDL composites significantly induced more bone formation than MDL indicating a higher osteoinduction rate (Table 9).

With regard to the ceramics, TCPS degraded and largely reduced in size over time while TCPB mainly retained its shape and size (Figure 14). Only one sample of TCPB induced bone formation while all TCPS resulted osteoinductive (Figure 14, Table 9). Similarly to composites, bone grew tight onto the surface of TCPS granules. Mature bone matrix entrapping osteocytes was observed and, on its external edge, bone formation was still ongoing as a seam of active osteoblasts and immature bone was visible (Figure 15). TCPS significantly induced more bone formation as compared to TCPB (Table 9).

Table 9. Histomorphometry results. The tests used were one-way ANOVA test for means (Tukey's) where a p-value smaller than 0.05 was considered as significant difference, and two tail t-test (for populations with different variance).

\begin{tabular}{|c|c|c|c|}
\hline & Bone incidence & $\begin{array}{l}\text { Bone volume } \\
{[\% \text { in available space] }}\end{array}$ & Statistical comparison \\
\hline MLD & $0 / 5$ & $0 \pm 0$ & \multirow{3}{*}{$\begin{array}{l}\text { MLD-MLDL, }<10^{-8}, \text { ANOVA } \\
\text { MLD-MDL, }>0.1 \text { (no), ANOVA } \\
\text { MLDL-MDL, }<10^{-5} \text {, ANOVA }\end{array}$} \\
\hline MLDL & $5 / 5$ & $7.8 \pm 2.3$ & \\
\hline $\mathrm{MDL}$ & $5 / 5$ & $2.1 \pm 3.3$ & \\
\hline TCPB & $1 / 5$ & $0.9 \pm 2.1$ & \multirow{2}{*}{$<0.002$, t-test } \\
\hline TCPS & $5 / 5$ & $18.7 \pm 6.6$ & \\
\hline
\end{tabular}



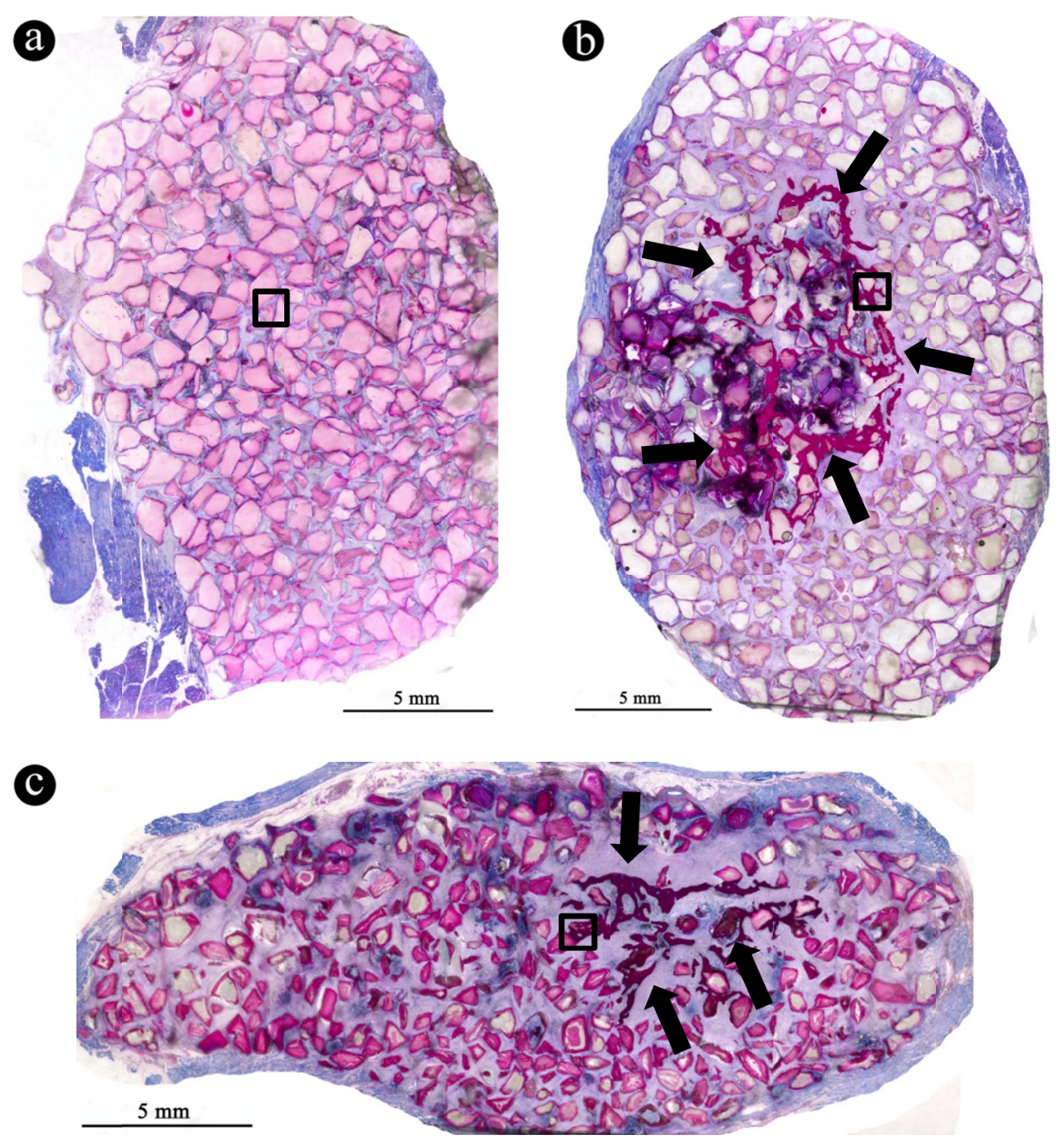

Figure 12. Low magnification scans of (a) MLD, (b) MLDL and (c) MDL explants stained with methylene blue and basic fuchsin. Arrows indicate bone (dark red) whereas granules have colors varying from white to pink. Soft tissues are colored with violet/blue. Black squares indicate the spots where high magnification images were taken with light microscopy (Figure 13).

\subsection{Discussion}

The results of this study showed that fluid uptake in biomaterials can be controlled by means of polymer monomer chemistry in the case of composite materials, or through the surface grain size (thus the surface area) in ceramics. Those materials that could absorb more fluids also showed higher degradability and protein adsorption potential. Besides this, they could induce heterotopic bone formation. However, the results obtained in one of the two classes of biomaterial could not be fully extrapolated to the other one due to multifactorial issues. 

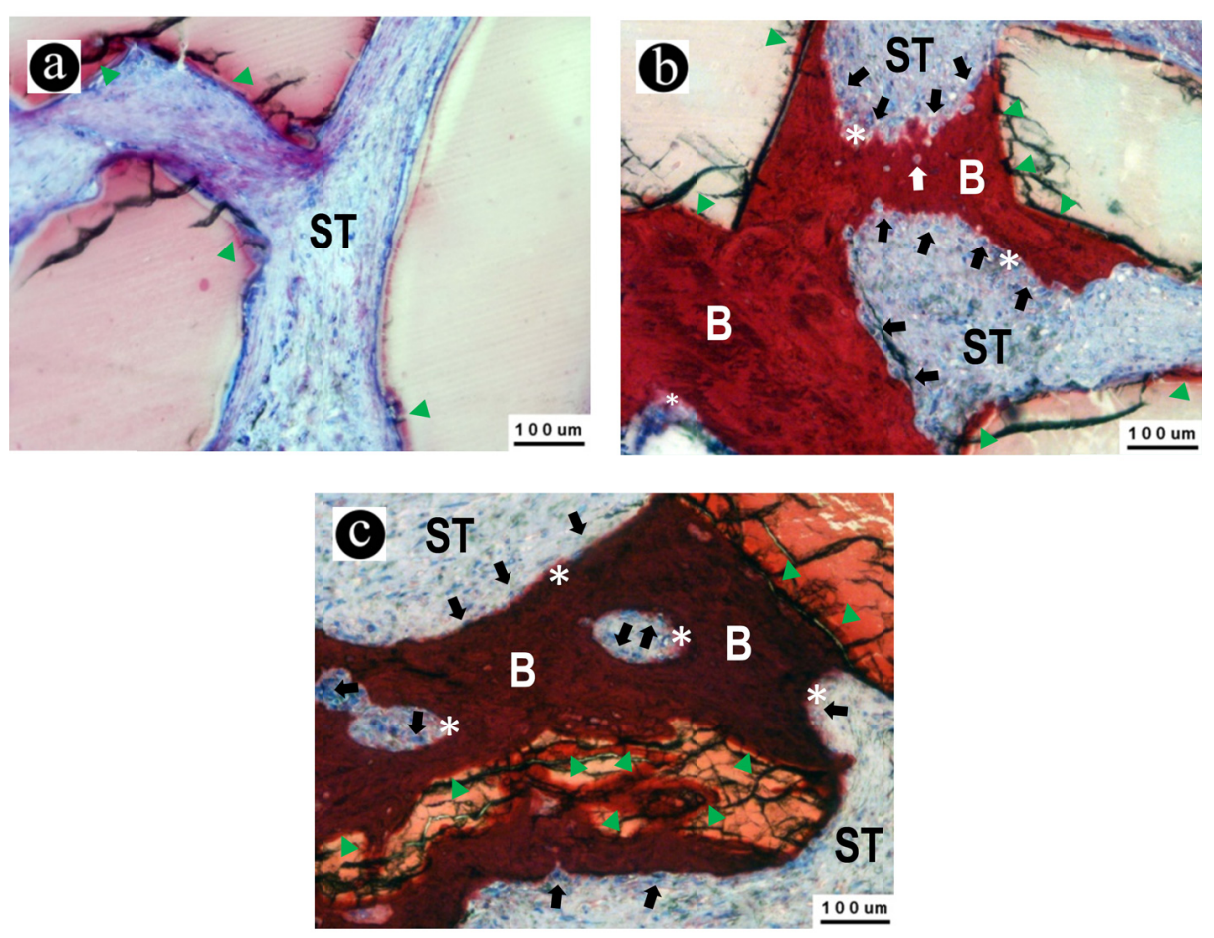

Figure 13. Microscopy details of (a) MLD, (b) MLDL and (c) MDL explants stained with methylene blue and basic fuchsin. Green triangles indicate surface mineralization layers onto the granules. Black arrows indicate active osteoblasts on immature bone matrix and white arrows show osteocytes. Stars indicate ongoing bone matrix formation, letters B and ST stands for mature bone and soft tissue respectively.

\subsubsection{Composites}

The composites had similar surface mineralizing potential, as within two days in simulated body fluid all granules were covered by mineralized apatite layers. After soaking in foetal bovine serum (FBS) solution for a week at body temperature, MLDL and MDL had comparable fluid absorption. Interestingly, these two composites also adsorbed similar amounts of serum proteins (Figure 6). In turn, MLD significantly took up less fluids and adsorbed less proteins (Figure 6). In this situation, as compared to $M L D$, the higher fluid uptake in MLDL and MDL allowed better contact between their surfaces and FBS, increasing the probability of serum protein adsorption. Similarly, short after implantation in vivo, biological molecules from body fluids, including clotting factors, could have largely adsorbed on the surfaces of MLDL and MDL allowing adhesion of inflammation cells.[216] 

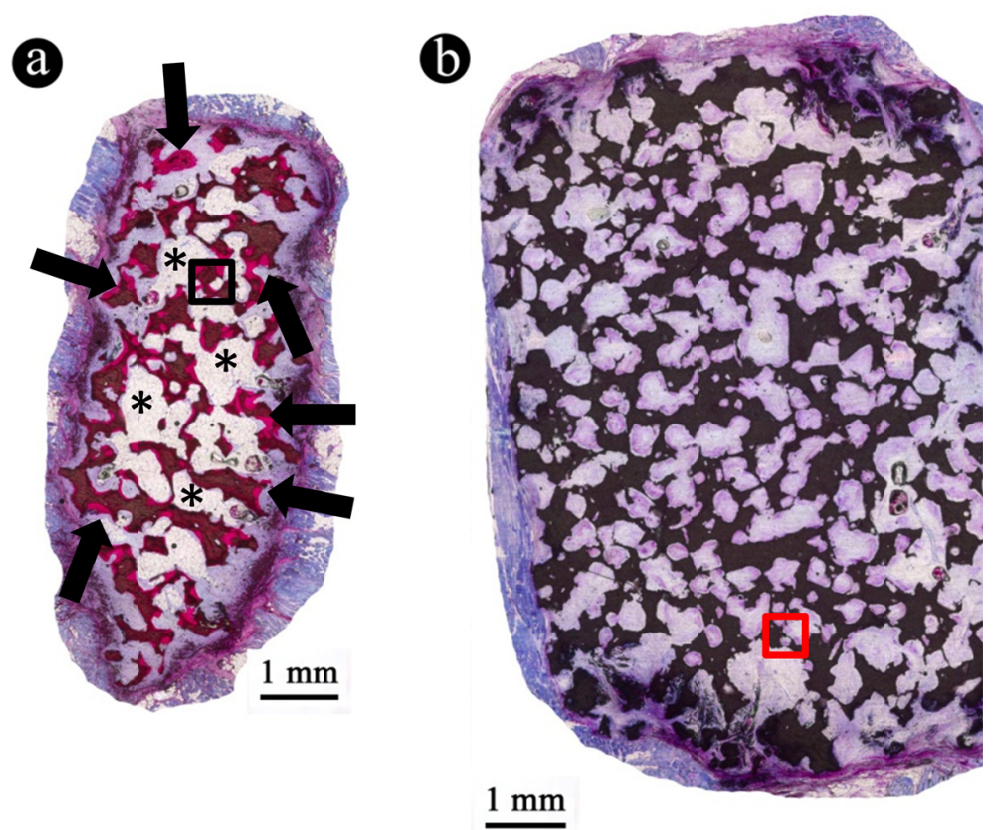

Figure 14. Low magnification scans of (a) TCPS and (b) TCPB explants stained with methylene blue and basic fuchsin. Arrows indicate bone (dark red) whereas ceramics are dark colored (i.e. brown and black). Soft tissues are colored with violet/blue and bone marrow is white (stars). Due to the long implantation time (i.e. 6 months) it may be well that bone marrow is a consequence of occurring bone remodeling. Squares indicate the spots where high magnification images were taken with light microscopy (Figure 14).
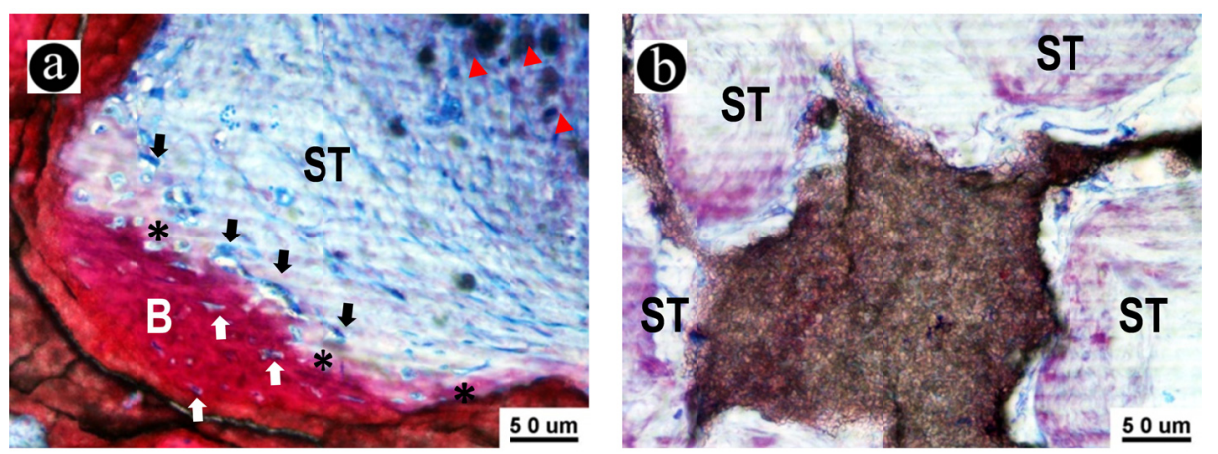

Figure 15. Microscopy details of (a) TCPS and (b) TCPB explants stained with methylene blue and basic fuchsin. Red triangles show residuals of degraded ceramic. Black arrows indicate osteoblasts and white arrows show osteocytes. Stars indicate ongoing bone matrix formation, letters B and ST stands for mature bone and soft tissue respectively. 
As already mentioned in the introduction, the initial inflammatory response to the implantation of biomaterials may be one of the osteoinduction triggers. ${ }^{[218-220,255,256 \text {, }}$ 386] In fact, osteoclastogenesis and osteoblastogenesis at the biomaterial surface may be mediated by macrophage adhesion and subsequent secretion of cytokines. Unpublished preliminary in vitro results of members from our group showed that the culture of murine monocyte/macrophage cell line RAW 264.7 on osteoinductive ceramic resulted in significantly higher levels of secreted IL-6 and IL -4 , cytokines responsible for osteoclastogenesis and foreign body giant cell fusion respectively, when compared to a non-inductive ceramic. Other data showed that osteoclastic markers in murine macrophage cell line $\mathbf{J} 774.2$ were significantly up-regulated during culture on osteoinductive ceramics, and stimulation of RAW 264.7 with osteoclast differentiation factor RANKL (receptor activator of NF-KB ligand) during culture on osteoinductive ceramics resulted in larger, more surface integrated osteoclast-like cells. Further evaluation of these macrophage/osteoclast culture systems may shed light on the potential osteogenic effects that such cell-material interactions may have on precursor cells. It should be observed that, in this study, the three composites had similar surface nano-structured topographies thus effects of surface topography on the composites in vivo performances can be excluded. Concluding, those composites (i.e. MLDL and MDL) that took up more fluids could quickly adsorb more biological molecules, which may have contributed to trigger certain inflammatory responses that may have increased the chance to trigger bone formation. On the contrary, things may have gone differently on MLD surfaces, which did not start any bone formation process. In vitro studies to unravel the role of early cellular response to osteoinductive composite are in progress. After six months we observed that MLDL showed significantly more bone compared to MDL. This may be explained by the fact that the composites have chemically different polymer phases. After five weeks accelerated degradation in phosphate buffered solution (PBS) we observed more fluid uptake in MDL than MLDL and MLD. Since the initial apatite chemistry and weight content was the same in the three materials, the different fluid absorption in the composites can be linked with the polymer physico-chemistry, i.e. the monomer and molecular weight. We observed that, after extrusion with apatite particles, differences in the viscosity molecular weights of the polymer phase in the three composites were minimal $( \pm 6 \mathrm{kDa})$. Based on this result, we assume that, in this study, the molecular weight did not play a crucial role. When the polymer is in contact with a liquid (e.g. water), its chains can move to reach an energetic equilibrium in the liquid-polymer contact eventually allowing more or less fluid penetration. ${ }^{[36,37]}$ The monomer type influences on the polymer crystallinity. Particularly, polylactide having high D,L-lactide content is more amorphous. ${ }^{[387]}$ Due to the little content of ordered regions (e.g. those 
containing L-lactide monomer), the chains in amorphous polymers can shift past each other and allowing the diffusion of aqueous fluids into their matrix. In this study MLD composite, with the least D,L-lactide content (i.e. 4\%) polymer, had little fluid uptake. On the contrary, MLDL and MDL (i.e. containing polymers having $30 \%$ and $100 \%$ D,L-monomer respectively) absorbed increasing amounts of fluids. Fluid uptake is crucial for polylactide-based materials (i.e. pure polymers and their composites) because they degrade by hydrolysis. During liquid absorption, the polymer undergoes random chain cleavage, which increases with the amounts of fluids taken up ${ }^{[387]} \mathrm{At}$ the same time, acid degradation products are released from the polymer decreasing the surrounding $\mathrm{pH}$ further accelerating degradation ${ }^{[349,387]}$ and leading to a decrease of molecular weight over time. Thus, based on the above concepts, the least crystalline polymers should have the largest degradation and vice versa. As expected, we observed quicker decrease in weight average molecular weight for composites having polymer phase containing more D,L-lactide. In particular, MDL composites had more rapid polymer autocatalysed hydrolysis rate than MLDL, which was in its turn higher than MLD (Figure 9). Interestingly, those materials that had quicker degradation (i.e. MDL and MLDL) could induce significant bone formation. It is well-known that calcium phosphate materials dissolve when in contact with water, thus increasing fluid uptake would facilitate the dissolution of apatite. Consistently, we observed increasing dissolution of the apatite phase with the increase of $D, L-l a c t i d e$ content. This was indicated by continuous decrease in apatite phase content over time (Table 6), which was significantly more pronounced for MDL. Correlated to this, calcium and phosphate ions were released into the degrading solution with amounts directly linked with the D,L-lactide content. Such ions are reported to trigger surface mineralization ${ }^{[253]}$ and are signaling molecules for bone cells. ${ }^{[226-228,252,321-323]}$ During time, because of the degradation of both polymer and apatite phases, overall mass loss of the composites occurred, which sharply increased with the D,L-content (Figure 6) and led to the disruption of MDL granules. From these results, we can conclude that, under the conditions of this study, the degradation of the composites was dependent on their capacity to uptake fluids. The observed trends of degradation in vitro could have happened in vivo as well. Histomorphometrical analysis indicated that MDL degraded more than MLDL. It may be well that bone formation may have been hindered by a series of causes. An implant formed by loose granules compacted in muscular pouches forms a porous material, where the porosity is given by the free space between the granules themselves. So, one reason might be the lack of an adequate supporting (porous) structure on which bone could grow due to the relatively too fast degradation of MDL. In fact, we observed that the granules had smaller size and were not close to each 
other to support bone bridging (in some cases the distance between MDL granules was $>1 \mathrm{~mm}$, Figure 12). Another cause may be the excessive release of degradation products (both polymer and apatite) from MDL, which may have somehow influenced on the surrounding conditions (e.g. $\mathrm{pH}$ and/or macrophage activity).

The formation of L-lactide monomer residuals, caused by the extrusion of $96 \% \mathrm{~mol}$. L-lactide/4\%mol. D-lactide copolymer, was reported.[336] Interestingly, those copolymers having higher post-extrusion amounts of L-lactide monomer also had higher hydrolytic degradation rate.[336] Other studies reported that, in poly $(D, L-$ lactide), increasing amounts of monomer residuals facilitate fluid uptake leading to larger hydrolysis. ${ }^{[411]}$ From these information, it may be expected that significant amounts of L-lactide and D,L-lactide monomers may have been generated after extrusion of the composites evaluated in this Chapter. It could be that such residuals played some role influencing on the composites degradation trends or even on their osteoinduction. However, for now no conclusion can be drawn and, to our best knowledge, there is no literature reporting the effect that monomer residuals may have on the interactions between the polymer-based biomaterials and biological surroundings. Therefore, in future it would be useful to investigate the possible role that the residual monomer content may have on the properties and biological performances of composites.

Besides the monomer content, the (semi)-crystallinity of the polymer matrix may be another important factor. It is influenced by the processing history and monomer chemistry, and on its turn it influences on the polymer properties such as fluid uptake, degradation and mechanical properties.[387] In particular, it has been reported affect the cell response to the biomaterial surface. ${ }^{[412,413]}$ It was observed that highly crystalline polyester surfaces were more efficient in supporting fibroblast growth, whereas amorphous ones were more efficient in supporting growth of osteoblasts. ${ }^{[413]}$ In this study, we did not evaluate the crystallinity changes and therefore it is recommended to consider the polymer crystallinity in future experiments.

Based on these results, the role of fluid uptake can be divided in two parts. Over a short time span, i.e. few weeks, large and fast fluid uptake favor bio-molecule adsorption triggering biological phenomena such as bone induction. On the other side, during longer periods (i.e. months), a material absorbing little amount of fluids degrades too slowly. Consequently, no available space for bone ingrowth would be formed and little amount of ions would be released slowing down or inhibiting bone formation. On the contrary, materials taking up excessive fluids would degrade too fast and may collapse or be disrupted, thus not offering anymore 
adequate support framework for bone forming cells and hindering the continuation of bone induction process where activated.

\subsubsection{Ceramics}

Ceramics had similar surface mineralizing potential as after two days in simulated body fluid the granules presented nano-textured apatite-like layers. Thanks to the smaller micro-structure (i.e. smaller grain size), TCPS had a higher surface area that increased its hydrophilicity as compared to TCPB. A larger amount of fluid was absorbed by TCPS, on which more serum proteins adsorbed as well. Similarly to what was said for the composites case, better contact with fluids transporting biomolecules favors their adsorption onto materials surfaces. It has been proposed that the presence of micro-structure and pores with large surface area favor the accumulation of body fluid proteins, such as fibrogen, and growth factors like as rhBMP2.[154, 228] Such molecules are acknowledged improving cell adhesion and trigger bone formation. Similarly to what was discussed for the composite, the larger fluid uptake may also have triggered inflammation cells to produce signals that later could initiate bone formation.[217-220, 255-257, 386] Besides enhancing protein adsorption, the surface micro- and nano-structural features such as grain and micro-pore size have been shown to play a crucial role in inducing the in vivo differentiation of stem cells into osteogenic lineages. When hydroxyapatite $(\mathrm{HA})$ with and without a microstructured surface was implanted in the muscle of dogs, it was reported that only those materials possessing a micro-structure could induce ectopic bone formation. ${ }^{[236,237]}$ Similar results were shown in studies comparing HA and biphasic calcium phosphate (BCP) ceramics with various micro-porosity. ${ }^{[228]}$ One of the possible causes proposed as crucial for heterotopic bone induction is the resorption/degradation with release of calcium ions having positive effect on cellular differentiation and activity. ${ }^{[252,321-323]}$ Consistently with literature, we observed that the ceramic inducing more bone formation (i.e. TCPS) had quicker dissolution in vitro with higher calcium ions release compared to TCPB. Further, the in vitro trend was confirmed by the observation that after six months of implantation, TCPS cylinders lost their shape and little amount of material remained as compared to TCPB. We can correlate the fast degradation of TCPS with its higher capacity to absorb fluids in its bulk, which favored its dissolution.

\subsubsection{Closing remarks}

By keeping separated the two families of materials, in this work we have reported that the capacity to uptake fluids influences the bone forming ability of calcium phosphate based biomaterials, where the materials absorbing more fluids induced 
larger heterotopic bone formation. As seen earlier, fluid uptake could favor various phenomena such as biomolecule adsorption and it accelerated the degradation facilitating the release of calcium and phosphate ions. These processes could later trigger osteogenic differentiation and bone formation by differentiated cells. Further to this, degradation leads to the formation of available space for bone ingrowth. However, when bone formation is slow (i.e. the case of composites) a too fast degradation might be detrimental as a framework for bone formation would no longer exist (i.e. the case of MDL). On the contrary, a fast degradation of the ceramic did not inhibit bone formation because the rate of bone growth was quite high (i.e. the case of TCPS). It is interesting to observe that both ceramics had a higher fluid uptake, with consequent larger protein adsorption and faster dissolution/degradation rate, as compared to the composites. Based on these considerations, we could explain a higher bone induction potential in both ceramics than the composites. However, MLDL and MDL composites triggered and supported larger heterotopic bone formation than TCPB ceramic which gave no bone formation. At the same time, TCPS induced most bone amongst all the materials analyzed. These discrepancies might be explained by the presence of multiple physicochemical factors between the two classes of materials. In fact, as mentioned earlier, composite materials differed only in their monomer chemistry, while the two ceramics differed in their surface grain size. On the contrary, when comparing the two classes of materials, they differ in chemistry (i.e. polymer and calcium phosphate) and surface topography (i.e. nano- and microtexture), which have various implications on ion release, protein adsorption and, ultimately, bone induction potential. Therefore, applying the same principle, in this case the role of fluid uptake in driving bone formation, is feasible when considering materials belonging to the same class (i.e. composites and ceramics), but not in a more general view to compare materials of different classes due to the multifactorial issue.

\subsection{Conclusion}

We have reported that the capacity to uptake fluids influences the bone forming ability of calcium phosphate based biomaterials, where the materials absorbing more fluids induced larger heterotopic bone formation. This principle might be applied to all biomaterials as it held true for two different kinds of material (i.e. composites and ceramics). However, it cannot be applied to compare the osteoinductive potential between biomaterials from different families. 


\section{ADDENDUM}

\section{6a.1. Introduction}

When polymers have comparable molecular weights, their monomer composition, besides influencing on their biological properties as seen previously, also affects their mechanical properties because it determines the molecular structure. As discussed previously, semi-crystalline polymers present ordered and compact molecular regions in their disordered entangled structure. These regions hinder the chain sliding movement when the polymer is under stress, rendering the whole structure stiffer. Polylactide with high content of L-lactide monomer, for example above $70 \% \mathrm{~mol}$. content, is semi-crystalline, whereas if it has high content of D,L-lactide monomer it will have an amorphous structure.

As observed previously, the polymer phase in the three composites has comparable molecular weight thus we may evaluate the effect of the monomer on their elastic and viscoelastic properties. We expect that the composites containing polymers with high L-lactide contents, i.e. MLD and MLDL, will have higher storage modulus and lower damping characteristics as compared to MDL. To test this, we performed dynamic mechanical analyses in dry conditions.

\section{6a.2. Method}

Bars $(50 \times 15 \times 2.5 \mathrm{~mm})$ of the three composites were prepared by hot pressing $\left(150 \pm 1^{\circ} \mathrm{C}, 3 \pm 0.5 \mathrm{~min}, 250 \pm 10 \mathrm{kN}\right)$ the granules into steel moulds. The surface of all samples was then etched with $1 \mathrm{M}$ sodium hydroxide $(\mathrm{NaOH}$, Merck, Darmstadt, Germany) at room temperature for $5 \pm 0.5$ minutes to obtain samples with similar surfaces. They were then sterilized with ethylene oxide (IsoTron Nederland BV, Ede, the Netherlands) and used for all the experiments described in this study. Afterwards, the bars were analysed with a dynamic mechanical analyzer (DMA 2980, TA Instruments, New Castle, DE, USA) in three-point bending, over a sweep of physiological frequencies $(1-10 \mathrm{~Hz}, 0.3 \mathrm{~Hz} / \mathrm{min})$ at $37 \pm 0.1^{\circ} \mathrm{C}$ in dry air with static force $0.53 \pm 0.01 \mathrm{~N}$ and dynamic displacement $10 \pm 0.01 \mu \mathrm{m}$. The samples were kept at $37 \pm 0.01^{\circ} \mathrm{C}$ for $15 \pm 1$ minutes to stabilize the material prior the measurements. The data measured were storage modulus and loss tangent.

\section{6a.3. Results and discussion}

The composites that contained polymers with L-lactide monomer, i.e. MLD and $M L D L$, had storage modulus significantly higher than the material with poly $(D, L-$ lactide) (Figure 16a). In general, the modulus in MLD and MLDL has negligible changes during the analysis showing these materials are stable over a sweep of 
physiological frequencies. On the contrary, the stiffness in MDL had a slightly increasing trend with the frequency. Since the analysis has been done by applying cyclic stresses, it may be that the polymer exhibited strain-stiffening behavior, presumably, because of the inability of the molecular chains to relax to their neutral conformation between loading cycles, thereby debilitating smooth intermolecular motion and requiring more stress for the same strain. Consistently, the loss tangent increased with the diminution of L-lactide content (Figure 16b), indicating that amorphous polymers have better damping properties. Interestingly, such damping properties significantly decrease over the frequency for MDL as a consequence of increasing stiffness as indicated by the corresponding storage modulus.
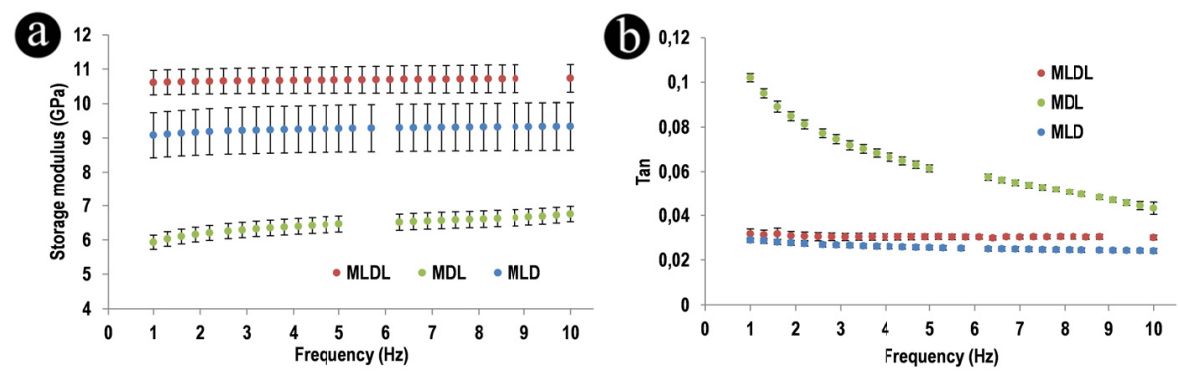

Figure 16. Measured (a) storage modulus and (b) loss tangent of the composites in dry conditions.

\section{6a.4. Conclusion}

The results reported in this Addendum demonstrate that poly(D,L-lactide) may not be a suitable polymer for composites to be used in load-bearing sites, whereas the copolymers gave rise to composite materials with higher dynamic stiffness and more stable damping properties over the considered stressing frequency range. This is a supplemental information for developing instructive composites with improved mechanical properties. From this, it appears that the composite comprising $70 \% \mathrm{~mol}$. L-lactide/30\%mol. D,L-lactide may be used in bone tissue regeneration in loadbearing sites as it is instructive and has dry dynamic mechanical properties close to those measured on dry human cortical bone extracted from femora ${ }^{[338]}$ (see Chapter 4). However, as already mentioned also in Chapter 4, improvements are necessary to guarantee suitable mechanical properties in moistened conditions (not measured for this composite). 



\section{CHAPTER 7}

Implications of polymer molecular weight in instructive composites for bone tissue regeneration 



\subsection{Introduction}

Whether it is simply maintenance or repair of small tissue damages, during our lifetime the body takes action to trigger tissue regeneration when required. Examples are haematopoiesis, skin and bone remodelling, and even the regeneration of organs like the liver. In these scenarios, it is believed that adult stem cells emerge from their niche, reach the required target sites and differentiate into cell-phenotypes that are able to synthesise the newly needed tissues. ${ }^{[46]}$ To guide the differentiation of stem cells into the correct cell type, the tissue micro- and nano-environment characteristics are crucial in instructing them. For instance it has been shown in vitro that, depending on the environmental stiffness caused by the presence of micro- and nano-columns, marrowderived mesenchymal stem cells will differentiate into either a neuronal, myoblastic and osteoblastic lineage. ${ }^{[99-103]}$ However, injured environments may lose their instructing property and, without proper or sufficient stimuli, stem cells may not be able to regenerate the required tissue. This may happen, for example, in myocardial tissue after infarction ${ }^{[84]}$ or in bone defects where large quantities of tissue are missing (i.e. critical sized bone defects) ${ }^{[85,86]}$ In such situations there is need of external intervention to support the cellular activity with stem cells or gene therapies, organ transplantation or grafting with healthy harvested tissues (i.e. auto- and allografts) or biomaterials.

Traditionally, biomaterial grafting consisted of providing the damaged site with a passive synthetic framework for cells. The need for full tissue regeneration is nowadays driving towards biomaterials that go beyond this concept, i.e. newly developed biomaterials should be designed to actively interact with the biological surroundings. It has been observed that, when stem cells attach to a biomaterial, the local surface characteristics of the material (e.g. topography, roughness, surface stiffness and chemistry) can induce various cellular behaviours. For example micro- and nano-rough surfaces can physically promote the adhesion of cells offering many contact sites for their filopodia. ${ }^{[152]}$ Further, such surfaces, having large surface area, can expose functional groups capable of binding specific proteins from body fluids. In this way cells are favoured to contact with the materials, on which different adsorbed protein motifs may trigger intracellular signalling pathways leading to various cellular responses, including their differentiation into specific cellular lines and synthesis of the desired tissues. ${ }^{103,153,154]}$

In bone tissue regeneration a subgroup of instructive biomaterials that have osteoinductive potential exists. These materials, following injury and colonization of inflammatory cells ${ }^{[215,216]}$ that later attract undifferentiated stem cells from the surrounding tissues, are capable of inducing stem cell differentiation into osteogenic phenotypes. ${ }^{[217-220]}$ This has been demonstrated in implantation sites where bone is normally not present (e.g. muscle, skin) without the support of exogenously added bone growth factors or (osteogenic) cells. ${ }^{[86]}$ Since the Sixties, when osteoinductivity of biomaterials was observed for the first time, ${ }^{[221]}$ this phenomenon has been 
reported for various materials, mainly sintered calcium phosphate ceramics ${ }^{[222-228]}$ but also in cements, ${ }^{[229,}{ }^{230]}$ coatings, ${ }^{[231,}{ }^{232]}$ porous Bioglass ${ }^{\mathrm{TM}},{ }^{233]}$ surface-treated titanium ${ }^{[234]}$ and more recently in composites of hydroxyapatite and polymer.[235] Numerous hypotheses have been formulated to explain the osteoinductivity of materials. For example, when composites of apatite nano-particles and poly $(D, L-$ lactide) with various content ratios were intramuscularly implanted in dogs, heterotopic bone formed only in the highest apatite containing formulation. The high apatite presence was proposed as the main osteoinduction trigger because it generated a rougher and disordered surface micro-topography (see Chapter 3 in this thesis), which may have positively affected (stem) cell differentiation into the osteogenic lineage. ${ }^{[195]}$ Further, it could have promoted the adsorption of proteins with calcium affinity such as vitronectin and bone morphogenetic protein, which favour osteoblast adhesion and bone formation. ${ }^{[153,250,251,346]}$ The high apatite content also increased calcium ion release from the composite, which may have saturated the surrounding fluids and induced the precipitation of calcium phosphate minerals leading to mineralized surfaces, ${ }^{[227,234,324]}$ while the rougher surface topography may have increased the number of nucleation sites ${ }^{[245]}$ for enhanced bio-mineralisation. In this way, a set of surface conditions for in vivo synthesis of new bone matrix by the composites may have been met.[226, 228, 234]

Attempting to design biomaterials able to support, or even trigger, bone tissue regeneration and to mechanically support physiological stresses, research has striven to fully or partially mimick the bi-phasic composition of bone (i.e. collagen matrix and carbonated nano-apatite) ${ }^{[21,22]}$ and its structure by developing composite biomaterials. Synthetic or natural polymers, thanks to their viscoelasticity, may be used in sites with mild mechanical stresses, such as cartilage or tendons. On the contrary, sites when stiffness is required together with damping characteristics such as in bone, filling polymers with inorganic particulate may be an interesting solution. Further, the presence of inorganic filler in the polymer would enhance the biological properties of the materials.

At the molecular level, a(n amorphous) polymer material is an entangled network of disordered interpenetrating randomly coiled macromolecules. When the polymer is in contact with a liquid (e.g. water), its chains can move to reach an energetic equilibrium in the liquid-polymer contact eventually allowing more or less fluid penetration. ${ }^{347,348]}$ When the molecular weight is high, the polymer material is less prone to uptake fluids. This phenomenon assumes particular importance for polyesters as they degrade hydrolytically. After liquid uptake, they undergo random chain cleavage, which increases with the amounts of fluids uptaken. During hydrolysis, more fluids are taken up and catalyse the cleaving process while free carboxylic acid groups released from the cleaved chains decrease the surrounding $\mathrm{pH}$ further enhancing the degradation. $[349,350]$ 
In calcium phosphate containing composites, the polyester molecular weight would determine the fluid uptake and indirectly guide the overall degradation. We hypothesize that composites containing amorphous polyesters with low molecular weight will absorb more fluids than those with higher molecular weight. A more rapid polyester hydrolysis would then generate rougher surface topographies with larger exposure of apatite particles, which in turn would enhance the release of calcium and phosphate ions. In addition, higher body fluid absorption will enhance biomolecular transport onto and into the biomaterial resulting in higher chances of protein adsorption and surface mineralisation, which play roles in recruiting and inducing (stem) cells to differentiate into osteogenic phenotypes. It is therefore expected that the polyester molecular weight in composites with calcium phosphate influences their bone forming ability.

To test this hypothesis, two polymers having same monomer chemistry but different molecular weights were used to prepare composites with the same calcium phosphate apatite content. As seen in Chapter 6, composites having (excessively) high L-lactide monomer content degraded slowly and were not osteoinductive, whereas those containing less L-lactide monomer, degraded more and triggered heterotopic bone formation. Consequently, in this study we choose poly $(D, L$-lactide $)$ as polymer phase of composites to study the effect of molecular weight on their osteoinduction. Once the composites were prepared with extrusion, we characterized their physicochemistry and in vitro performance in terms of degradation, surface mineralisation and serum protein adsorption. Thereafter we evaluated in vivo mineralisation, degradation and osteoinductive potential after intramuscular implantation of the composites in dogs for three months.

Besides this, the polymer molecular weight also influences on the viscoelastic properties of the resulting composites. Polymers with low molecular weight are composed by shorter chains that have more freedom to slide past each other when mechanically stressed. Under the same filler content and same monomer chemistry, this fact would lead to composite materials with lower stiffness and higher damping capacities as compared to those containing higher molecular weight polymers. Therefore, we evaluated also the effect of molecular weight on the dynamic mechanical properties of the two materials over a physiological frequency sweep to simulate the natural cyclic stresses occurring in bone.

\subsection{Materials and methods}

\subsubsection{Apatite preparation and characterization}

Nano-apatite powder was synthesized by adding $\left(\mathrm{NH}_{4}\right)_{2} \mathrm{HPO}_{4}$ (Fluka, Steinheim, Germany) aqueous solution ( $\mathrm{c}=63.12 \mathrm{~g} \mathrm{~L}^{-1}$ ) to $\mathrm{Ca}\left(\mathrm{NO}_{3}\right)_{2} \cdot 4 \mathrm{H}_{2} \mathrm{O}$ (Fluka) aqueous solution ( $\mathrm{c}=117.5 \mathrm{~g} \mathrm{~L}^{-1}$ ) at the controlled speed of $12.5 \mathrm{~mL} \mathrm{~min}^{-1}$ and $80 \pm 5^{\circ} \mathrm{C}$, with the reaction $\mathrm{pH}$ kept above 10 by using ammonia (Fluka). After precipitation, the resulting powder 
was aged overnight, washed with distilled water to remove ammonia, dehydrated in acetone (Fluka) and finally dried at $60 \pm 1^{\circ} \mathrm{C}$. Its chemistry was then investigated with $\mathrm{X}$ ray diffractometry (XRD, MiniFlex II, Rigaku, Japan) using Cu K radiation ( $\lambda=1.54056 \AA$ ) operating at $30 \mathrm{kV}$ and $15 \mathrm{~mA}$. Spectra were collected at $0.083 \mathrm{deg} \mathrm{sec}^{-1}$ in the 29 range 5-90 deg. Unit cell parameters of the powder were determined from XRD data using the software Jade (v6.5.26, Materials Data Inc., Livermore, CA, USA). Following background subtraction (cubic spline method) and pattern smoothing (parabolic Savitzky-Golay filter set at 15 points), individual diffraction peaks were fitted $(\mathrm{R}<7 \%)$ with pseudo-Voigt profiles (Lorentzian factor set to 0.65$)$ and the unit cell parameters were estimated after a cell refinement procedure for hexagonal lattice P63/m. Fourier transform infrared spectrometer (FTIR, Spectrum 1000, Perkin Elmer, Waltham, MA, USA) was used to chemically characterize the precipitated powder with a typical $\mathrm{KBr}$ pellet technique. Spectra were collected in the range $400-4000 \mathrm{~cm}^{-1}$ and analysed with the software OriginPro (v8.0773, OriginLab Corporation, Northampton, MA, USA) without any pattern elaboration. The apatite particle size and morphology were characterized using transmission electron microscopy (TEM, Tecnai-200FEG, FEI Europe, Eindhoven, the Netherlands).

\subsubsection{Composite preparation and characterization}

The precipitated powder was extruded with low and high molecular weight poly(D,Llactide) (declared inherent viscosity $0.39 \mathrm{dL} \mathrm{g}^{-1}$ with residual monomer $<2 \%$, and 4.02 $\mathrm{dL} \mathrm{g}^{-1}$ with residual monomer $<2.5 \%$, PDL-L and PDL-H respectively; Purac Biomaterials BV, Gorinchem, the Netherlands) to prepare two dense $50 / 50 \%$ wt. apatite/polymer composites (ML and $\mathbf{M H}$ respectively). The extrusion was done using a mini vertical conic twin-screws extruder (RD11-H-1009-025-4, DSM Research BV, Geleen, the Netherlands; top screw diameter: $10 \mathrm{~mm}$; bottom screw diameter: $4.15 \mathrm{~mm}$; screw thread: $8 \mathrm{~mm}$; screw length: $108 \mathrm{~mm}$ ) with screws speed set at $100 \pm 1 \mathrm{rpm}$ for a mixing time of $5 \pm 0.5$ minutes. Due to the different starting inherent viscosity of the polymers, the extrusion temperature was set at $150 \pm 1^{\circ} \mathrm{C}$ with $\mathrm{PDL}-\mathrm{L}$ or $190 \pm 1^{\circ} \mathrm{C}$ with $\mathrm{PDL}-\mathrm{H}$ to allow enough polymer softening with minimal thermal degradation. Granules $(0.5-1 \mathrm{~mm})$, discs $(\varnothing 8 \times 0.4 \mathrm{~mm})$ and bars $(50 \times 15 \times 2.5 \mathrm{~mm})$ were prepared. To guarantee similar surface topographical features, all samples were surface etched in $0.75 \mathrm{M}$ sodium hydroxide ( $\mathrm{NaOH}$, Merck, Darmstadt, Germany) at room temperature for $5 \pm 0.5$ minutes. All the samples were then sterilized with ethylene oxide (IsoTron Nederland BV, Ede, the Netherlands). Sterile materials were then used for all the experiments described in this study.

To evaluate whether the polymer phase changed during manufacturing, we measured the viscosity of the polymer as supplied and the polymer phase in the prepared materials. In the case of composites, we dissolved the samples in chloroform $\left(\mathrm{CHCl}_{3}\right.$, 
Sigma-Aldrich, Steinhem, Germany) at the concentration of $4 \mathrm{mg} \mathrm{mL}^{-1}$. We then separated apatite particles from the polymer component through vacuum filtering with glass funnels (ROBU, Germany; borosilicate 3.3 with glass filter having porosity \#5) and PTFE membrane filter (Toyo Roshi Kaisha, Advantec, Japan; pore size $0.1 \mu \mathrm{m}$ ) and let chloroform completely evaporate to obtain the polymer samples. Afterwards, we dissolved again the filtered polymers in chloroform (Sigma-Aldrich) at a concentration of $0.1 \mathrm{~g} \mathrm{dL}^{-1}$ and measured the relative viscosity $\left(\eta_{\text {rel }}\right)$ using an Ubbelohde (ASTM) viscometer (OC, PSL-Rheotek, Burnham on Crouch, United Kingdom) at $25 \pm 0.1^{\circ} \mathrm{C}$. From $\eta_{\text {rel }}$ we could determine the inherent $\left(\eta_{\text {inh }}\right)$ and intrinsic $(\langle\eta\rangle)$ viscosity (Solomon-Ciută). ${ }^{[356]}$ By using Mark-Houwink equation, the weight average molecular weight $\left(\mathrm{M}_{\mathrm{w}}\right)$ of the polymers was calculated, as follows:[337]

$\eta_{\text {rel }}=\mathrm{t}_{\text {pol }} / \mathrm{t}_{\text {chlor }}$

$\eta_{\mathrm{sp}}=\eta_{\text {rel }}-1$

$\eta_{\text {inh }}=\ln \left(\eta_{\text {rel }}\right) / \hat{c}$

$<\eta>=\left[\operatorname{sqrt}\left(2 \cdot\left(\eta_{\mathrm{sp}}-\ln \left(\eta_{\mathrm{rel}}\right)\right)\right)\right] / \hat{c}$

$\ln \left(\eta_{\text {inh }}\right)=\ln (K)+\bar{a} \cdot \ln \left(M_{w}\right)$ from which $M_{w}=\exp \left[\left(\ln \left(\eta_{\text {inh }}\right)-\ln (K)\right) / \bar{a}\right]$

where $t_{p o l}$ and $t_{c h l o r}$ are the measured time for the solution of polymer and of pure chloroform to flow in the viscometer respectively, and $\hat{c}$ is the polymer concentration in chloroform. The used Mark-Houwink constants related to inherent viscosity for poly $\left(D, L\right.$-lactide) were $K=1.8 \cdot 10^{-4} \mathrm{dL} \mathrm{g}^{-1}$ and $\bar{a}=0.72 .{ }^{[337]}$

Scanning electron microscopy (SEM) in secondary electron modality was performed on loose granules to evaluate their surface topography and apatite exposure. Some granules of the two materials were also embedded in epoxy resin (Sigma-Aldrich, Steinheim, Germany), sectioned to have cross-sections of the granules and observed in backscattered modality (BSEM) to evaluate their bulk and the effect of alkali treatment. To evaluate the extent of apatite exposure (caused by the etching), at least twenty random granules were considered in BSEM images. The granule total perimeter $\left(\mathrm{P}_{\mathrm{gr}}\right)$ and the perimeter of the apatite layer on the granule $\left(\mathrm{P}_{\mathrm{ap}}\right)$ were measured using the tool perimeter measurement in ImageJ $(\mathrm{v} 1.43 \mathrm{u}, \mathrm{NIH}, \mathrm{USA})$. The covering perimeter of apatite was estimated as percentage of perimeter for each granule:

$\mathrm{P}_{\%}=100$ * $\left(\mathrm{P}_{\mathrm{ap}} / \mathrm{P}_{\mathrm{gr}}\right)$

The values were then averaged and their standard deviation was calculated. BSEM also allowed measuring the average thickness of these apatite layers still using Image J tools with the help of the scale bar. As the sectioning plane was random respect to the granules, it was expected that the measureable characteristics of the layers (i.e. their perimeter around the granules and thickness) had a normal distribution of probability and thus, statistically speaking, the method here proposed might be used to evaluate the materials. 
The effective content by weight (\%wt.) of apatite $\left(u_{\text {apatite }}\right)$ and polymer $\left(u_{\text {polymer }}\right)$ in the extruded composites was determined by burning the polymer out from the composites in a sinter oven (C19, Nabertherm, Lilienthal, Germany) at $900 \pm 5^{\circ} \mathrm{C}$ for two hours. The bulk and surface chemistry of the composites were analysed with XRD and FTIR as described earlier. Dynamic contact angle measurements were performed to evaluate the surface hydrophilicity and drop spreading rate on the surface of the composites. At room temperature a drop of $0.6 \mu \mathrm{l}$ of distilled water was placed on the surface of the discs. Pictures were taken with a digital camera (PowerShot SX200 IS, Canon Nederland NV, Amstelveen, the Netherlands) immediately after the drop placement and then every 5 seconds for 5 minutes. Measurements of the contact angle from the pictures were done with the software ImageJ ( $1.43 \mathrm{u}, \mathrm{NIH}, \mathrm{USA})$ using the freely distributed plugin Drop-Shape Analysis working on the snake-based approach.[335]

\subsubsection{In vitro degradation of the composites}

A saline physiological solution (SPS) was prepared by dissolving sodium chloride $(\mathrm{NaCl}$, Merck; $c=8 \mathrm{~g} \mathrm{~L}^{-1}$ ) and 4-(2-hydroxyethyl)-1-iperazineethane-sulfonic acid (HEPES, Sigma-Aldrich; $\left.\mathrm{c}=11.92 \mathrm{~g} \mathrm{~L}^{-1}\right)$ in distilled water. The $\mathrm{pH}$ of the solution was adjusted to 7.3 with $2 \mathrm{M} \mathrm{NaOH}$ (Merck) at $37^{\circ} \mathrm{C}$. Sterile granules of each composite $(0.5 \pm 0.01 \mathrm{~g})$ were weighed before use $\left(\mathrm{m}_{0}\right)$ and soaked in $200 \mathrm{~mL}$ SPS (in triplicate) at $37 \pm 1^{\circ} \mathrm{C}$ for three months under a 3-week refreshing regime. Every three weeks, the $\mathrm{pH}$ of the degrading solution was recorded with a pH-meter (Orion 4 Star, Thermo Scientific, USA). Using the solution removed at every refreshing time point, the concentration (in $\mu \mathrm{M})$ of calcium and phosphate ions in the degrading solution was measured using appropriate biochemical kits (QuantiChrom ${ }^{\mathrm{TM}}$ Calcium assay kit, BioAssay Systems, USA; PhosphoWorks ${ }^{\mathrm{TM}}$ Colorimetric Phosphate Assay kit Blue Color, Bioquestlnc, USA) with the help of a spectrophotometer (AnthosZenyth 3100, AnthosLabtec Instruments $\mathrm{GmbH}$, Salzburg, Austria) and absorbance filter of $620 \mathrm{~nm}$ for both assays. After 12 weeks the granules were removed from the degrading media, the excess SPS was wiped away and they were carefully weighed ( $\left.m_{\text {wet }}\right)$. Afterwards, they have been vacuum-dried at $37 \pm 1^{\circ} \mathrm{C}$ until their weight was stable and then were weighed again $\left(m_{\text {dry }}\right)$. The mass loss and fluid uptake of the composites were determined as:

mass loss $=100 *\left(m_{0}-m_{\text {dry }}\right) / m_{0}$

fluid uptake $=100 *\left(m_{\text {wet }}-m_{\text {dry }}\right) / m_{\text {dry }}$

Following the method explained earlier, part of the granules was embedded in epoxy resin (Sigma-Aldrich), sectioned and observed at BSEM to evaluate the changes (in perimeter and thickness) of the surrounding apatite layers. Another part of the degraded samples was heated at $900^{\circ} \mathrm{C}$ to burn the polymer phase out and determine the final effective apatite and polymer percentage contents (in \%wt., $p_{\text {ap }}$ and $p_{p o l}$ respectively). We then calculated the phase content change as follows: 
$\bar{u}_{\text {apatite }}=100 \cdot \mathrm{m}_{\text {dry }} \cdot p_{\text {ap }}$

$\bar{u}_{\text {polymer }}=100 \cdot \mathrm{m}_{\text {dry }} \cdot p_{\text {pol }}$

apatite phase change $=100 \cdot\left(\bar{u}_{\text {apatite }}-u_{\text {apatite }}\right) / u_{\text {apatite }}$

polymer phase change $=100 \cdot\left(\bar{u}_{\text {polymer }}-u_{\text {polymer }}\right) / u_{\text {polymer }}$

where $u_{\text {apatite }}$ and $u_{\text {polymer }}$ are the initial phase contents (in grams) of apatite and polymer (as determined in §7.2.2). Following the procedure described in §7.2.2, the remnant part of the degraded samples was used to evaluate the degradation of the polymer phase by measuring its post-degradation inherent/intrinsic viscosity and weight average molecular weight after 12 weeks.

\subsubsection{In vitro surface mineralisation of the composite}

Simulated body fluid (SBF) was prepared according to Kokubo[247] by dissolving reagent grade chemicals (Merck) in distilled water strictly in the following order: $\mathrm{NaCl}, \mathrm{NaHCO}_{3}$, $\mathrm{KCl}, \mathrm{K}_{2} \mathrm{HPO}_{4} \cdot 3 \mathrm{H}_{2} \mathrm{O}, \mathrm{MgCl}_{2} \cdot 6 \mathrm{H}_{2} \mathrm{O}, \mathrm{CaCl}_{2}$ (calcium ion standard solution $0.1 \mathrm{M}$, Metrohm, Herisau, Switzerland) and $\mathrm{Na}_{2} \mathrm{SO}_{4}$. The fluid was then buffered to $\mathrm{pH} 7.4$ at $36.5^{\circ} \mathrm{C}$ using Tris $\left(\left(\mathrm{CH}_{2} \mathrm{OH}\right)_{3} \mathrm{CNH}_{3}\right)$ and $1 \mathrm{M} \mathrm{HCl}$. The final solution had an ion concentration (in $\mathrm{mM}$ ) as follows: $\mathrm{Na}^{+}, 142 ; \mathrm{K}^{+}, 5 ; \mathrm{Mg}^{2+}, 1.5 ; \mathrm{Ca}^{2+}, 2.5 ; \mathrm{Cl}^{-}, 147.8 ;\left(\mathrm{HCO}_{3}\right)^{-}, 4.2 ;\left(\mathrm{HPO}_{4}\right)^{2-}$, 1; $\left(\mathrm{SO}_{4}\right)^{2-}, 0.5$. Granules of the composites $(0.25 \mathrm{~g})$ were soaked in $100 \mathrm{~mL} \mathrm{SBF}$ (in triplicate) at $37 \pm 1^{\circ} \mathrm{C}$ for two days. The granules were then removed from SBF, carefully rinsed with distilled water and dried. Part of them was gold-sputtered and observed with SEM in secondary electron modality. Following the method explained earlier, other granules were embedded in epoxy resin (Sigma-Aldrich), sectioned and observed at BSEM for quantification (in perimeter and thickness) of mineralized apatite layers.

7.2.5. Protein adsorption and fluid uptake from $0.1 \%$ foetal bovine serum (FBS)

Sterile granules $(0.3 \mathrm{~g})$ of the composites were placed in $2 \mathrm{~mL}$ of $0.1 \%$ foetal bovine serum (FBS, Invitrogen, Darmstadt, Germany) containing $0.0025 \% \mathrm{v}$. sodium azide to prevent bacterial infection (in triplicate). They were incubated at $37 \pm 0.5^{\circ} \mathrm{C}$ and $5 \% \mathrm{CO}_{2}$ for one week. Serum proteins adsorbed from FBS were measured after one and seven days using micro BCA assay kit (Pierce Biotechnology Inc., Rockford, IL, USA) and spectrophotometer (Anthos) with absorbance filter of $595 \mathrm{~nm}$. The analysed granules were used also to estimate the fluid uptake as described earlier.

\subsubsection{Animal experiments}

With the permission of the local animal care committee (Animal Center, Sichuan University, Chengdu, China; protocol \#P11029), granules of the two composites (1 cc) were implanted in the paraspinal muscles of six skeletally mature mongrel dogs (male, 1-4 years old, weight $10-15 \mathrm{~kg}$ ) for 12 weeks to evaluate the tissue reaction and osteoinductive property of the composites. The surgical procedure was performed under 
general anaesthesia (pentobarbital sodium, Organon, the Netherlands; $30 \mathrm{mg} \mathrm{kg}^{-1}$ body weight) and sterile conditions. The back of the dogs was shaved and the skin was cleaned with iodine. A longitudinal incision was made and the paraspinal muscle was exposed by blunt separation. Longitudinal muscle incisions were subsequently made with a scalpel and separate muscle pouches were created by blunt separation. The composites granules were then placed in the pouches and the wound was closed in layers using silk sutures. After surgery, the animals received an intramuscular injection of penicillin for three consecutive days to prevent infection. Twelve weeks after implantation, the animals were sacrificed and the samples were harvested with surrounding tissues and fixed in $4 \%$ buffered formaldehyde solution $(\mathrm{pH}=7.4)$ at $4^{\circ} \mathrm{C}$ for one week. After rinsing with phosphate buffer saline (PBS, Invitrogen), the samples were trimmed from surrounding soft tissues and split in two parts: about $3 / 4$ for histological observations and $1 / 4$ for degradation analysis. The parts for histology were dehydrated in a series of ethanol solutions $(70 \%, 80 \%, 90 \%, 95 \%$ and $100 \% \times 2)$ and embedded in methyl metacrylate (MMA, LTI Nederland, the Netherlands). Non-decalcified histological sections (10-20 $\mu \mathrm{m}$ thick) were made using a diamond saw microtome (Leica SP1600, Leica Microsystems, Germany). Sections for light microscopy observations were stained with $1 \%$ methylene blue (Sigma-Aldrich) and $0.3 \%$ basic fuchsin (Sigma-Aldrich) solutions. The sections were observed with a light microscope (Nikon Eclipse E200, Japan) to analyse the tissue reaction and bone formation. BSEM was also performed on the sectioned samples to further evaluate the materials in terms of degradation, mineralized surface (including quantitative analysis as described earlier) and bone formation. Before use, the other parts of the explants were rinsed in $1 \%$ triton X-100 (Sigma-Aldrich) in phosphate buffered saline to completely remove the tissues from the granules. Afterwards the granules were washed several times in distilled water and vacuum-dried at $37 \pm 1^{\circ} \mathrm{C}$ for at least 48 hours. Part of these granules was heated at $900^{\circ} \mathrm{C}$ to burn the polymer phase out and determine the final effective apatite and polymer percentage contents (in \%wt., $p_{a p}$ and $p_{p o l}$ respectively) and have an idea on possible changes in the composite composition. Following the procedure described in $\$ 7.2 .2$, the remnant part of the samples was used to evaluate the degradation of the polymer phase by measuring its post-implantation inherent/intrinsic viscosity and weight average molecular weight after 12 weeks in vivo.

\subsubsection{Dynamic mechanical analysis}

Bars were analysed with a dynamic mechanical analyzer (DMA 2980, TA Instruments, New Castle, DE, USA) in three-point bending, over a sweep of physiological frequencies $\left(1-10 \mathrm{~Hz}, 0.3 \mathrm{~Hz} \mathrm{~min}^{-1}\right)$ at $37 \pm 0.1^{\circ} \mathrm{C}$ with static force $0.53 \pm 0.01 \mathrm{~N}$ and dynamic displacement $10 \pm 0.01 \mu \mathrm{m}$ in dry air conditions. The samples were kept at $37 \pm 0.01^{\circ} \mathrm{C}$ for 
$15 \pm 1$ minutes to stabilize the material prior the measurements. The data measured were storage modulus and loss tangent.

\subsubsection{Statistical analysis}

Two tail t-test (for populations with different variance) and post-hoc Tamhane ANOVA test were used to evaluate differences in the results. The choice between the two tests relied on the size of the compared data. If the data populations to be compared were two, t-test was use. If populations were more, ANOVA was used. A p-value lower than 0.05 was considered as significant difference in both statistical tests. The analyses were performed using Origin software (v8.0773, OriginPro, Northampton, MA, USA).

\subsection{Results}

7.3.1. Physicochemical characterization of the synthesised apatite

Using XRD we observed that the spectrum of the synthesized powder (Figure 1a) was comparable to the international JCPDS 9-432 reference for hydroxyapatite. Since the powder was neither sintered nor calcined, the diffraction peaks were broader than the international reference, indicating low crystallinity and confirming we obtained a calcium phosphate apatite powder. Calculations on the diffractometer data led to unit cell parameters $a=9.412 \pm 0.047 \AA$ and $c=6.880 \pm 0.011 \AA$, which are characteristic for synthetic apatite. ${ }^{[314]}$ FTIR showed vibrational bands around 604, 632, 962, 1031 and $1095 \mathrm{~cm}^{-1}$ (Figure 1b), which are typical for a calcium phosphate apatite. ${ }^{[351]}$ Acicularshaped apatite particles, with dimensions ranging from 200 to $400 \mathrm{~nm}$ in length and 20 to $50 \mathrm{~nm}$ in width, were observed in TEM images (Figure 1c).

\subsubsection{Composites characterization}

Two composites (ML and MH respectively) were successfully prepared by extruding low and high molecular weights poly(D,L-lactide) with calcium phosphate apatite particles. Measurements with Ubbelohde viscometer showed significant decreases in the weight average molecular weight for the polymer phase in both composites (Table 1), which indicates degrading effects of extrusion (i.e. thermal degradation and friction with apatite) on the polymer phases. In particular, this effect was larger in the case of higher molecular weight polymer. This fact is in line with observations reported in literature, ${ }^{[336]}$ and our results in Chapter 4. However, differences in the molecular weight between the two polymers after extrusion with apatite were still observed and therefore the two composites contained significantly different molecular weight polymers (Table 1). Chemical characterization with XRD and FTIR confirmed that the two composites had similar surface and bulk composition. Diffractometer patterns showed amorphousness of the pure polymers and the presence of apatite in the composites (Figure 1a). The infrared vibrational bands of the two polymers were similar demonstrating chemical 
equivalence, while the patterns of the two composites displayed all the polymers and apatite bands demonstrating that the apatite particles were successfully introduced into the polymers (Figure 1b). After burning the polymers out, only apatite was left and the composition of the two composites could be determined (Table 2), resulting close to the expected contents of $50 \%$ wt. In particular, no significant differences in the initial apatite/polymer content between $\mathrm{ML}$ and $\mathrm{MH}$ were observed ( $p>0.73$ ). Scanning electron microscopy (SEM) images of loose granules demonstrated similar nano-rough surface topographies for both composites with exposed acicular-shaped apatite nanoparticles that might be the main responsible for the rough topographies (Figure 2a,c). Homogeneous cores, with no large apatite agglomerates, were observed in backscattered scanning electron (BSEM) images of the cross-sectioned granules (Figures $2 b, d$ ). Alkali treatment affected the composites surface, resulting in a partial removal of the polymer and exposure of apatite particles (Figure $2 b, d)$. In the two materials, the exposed apatite layers had similar average thickness $(p>0.28)$ and they surrounded the granules covering similar percentage perimeters $(p>0.8)$ (Table 3 ) indicating that alkali treatment had similar effect on the two materials.
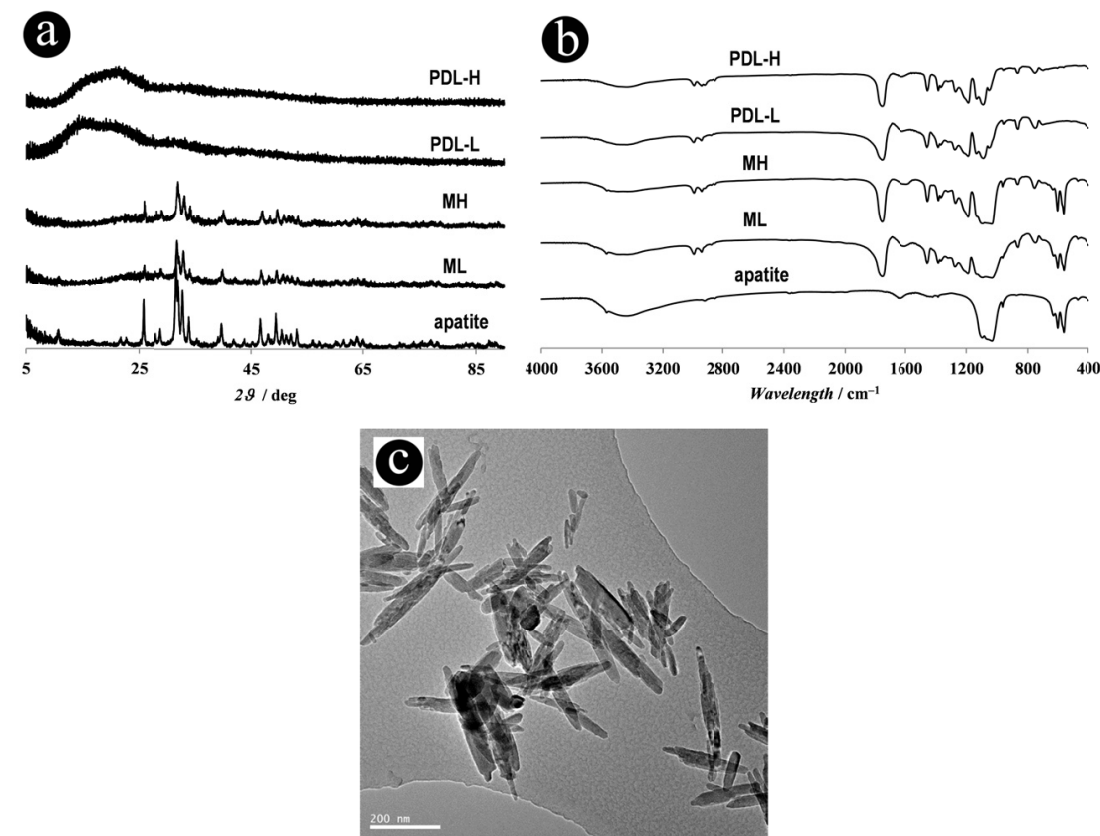

Figure 1. (a) XRD and (b) FTIR spectra for apatite, the two polymers (PDL-H and PDL-L) and the composites thereof ( $\mathrm{MH}$ and $\mathrm{ML}$ ). Polymers have amorphous component as demonstrated by their broad XRD patterns. From the composite XRD spectra it can be seen that apatite was introduced into the two polymers. These results are confirmed by the FTIR spectra, showing that vibrational bands of the composites include those of apatite and of the two polymers. (c) TEM image of apatite particles. PDL-H and $P D L-L$ indicate high and low molecular weight poly $(D, L-l a c t i d e)$ respectively; $M H$ and $M L$ indicate composites prepared with high and low molecular weight polymer respectively. TEM scale bar is $200 \mathrm{~nm}$. 
Contact angle, when measured as soon as distilled water was placed on the surfaces (time $0 \mathrm{sec}$ ), showed close values for both composites demonstrating their similarity in surface hydrophilicity (i.e. equivalent surface energy). However, within five minutes ML had a more pronounced decrease in contact angle (Figure 4a), i.e. a quicker spreading, roughly indicating a higher rate in water absorption than $\mathrm{MH}$.

\subsubsection{In vitro degradation of the composites in saline physiological solution (SPS)}

In a period of three months the composites degraded as demonstrated by their mass loss, continuous release of calcium and phosphate ions (Table 4, Figure $5 a, b$ ) and a slight increase of their apatite phase contents $(p<0.001$ and $p<0.02$ for $M L$ and $M H$ respectively) (Table 2). By considering the two phases separately, we observed that in both materials the largest phase loss occurred for the polymer phase (Table 2). However, the phase losses were similar $(p>0.55)$ in the two materials and, consistently, we also observed that ML and MH did not have significantly different bulk degradation as indicated by similar mass loss, comparable ion release (Table 4, Figure 5a,b) and from BSEM images showing that the granule bulks were still dense with no sign of significant bulk degradation (e.g. cracks or pores; Figure 3). However, degradation at the edge of the granules was observed in both composites (Figure 3). Interestingly, the two materials differed in fluid uptake where ML absorbed significantly more fluids than $\mathrm{MH}$ (Table 4). Fluid absorption triggered the polymer hydrolysis leading to significant decrease in weight average molecular weight in both materials (Table 1). When compared to their starting molecular weights, the polymer phase had similar decreases (in percentage) for both materials (Table 1). This indicates that, over a period of 12 weeks, the amount of fluids absorbed may not play a significant role in controlling the hydrolysis. However, the polymer phases in the two degraded materials still significantly differed in their molecular weight. Negligible pH changes (Figure $5 \mathrm{c}$ ) were seen because the release of calcium and phosphate ions may have compensated for the acidity provoked by the polymer hydrolysis. This effect may have also hindered the process of polymer hydrolysis autocatalysis, typical of polyesters. ${ }^{[349,350]}$ However, no different effects on $\mathrm{pH}$ were seen for both materials (Figure $5 c$ ) as they had a similar degradation and ion release. Due to the contact with aqueous fluid, the initial apatite layers surrounding the granules decreased their dimensions over time, with no significant difference between the two materials ( $p>0.6$ and $p>0.4$ for perimeter and thickness respectively) (Table 3 , Figure 3 ). 


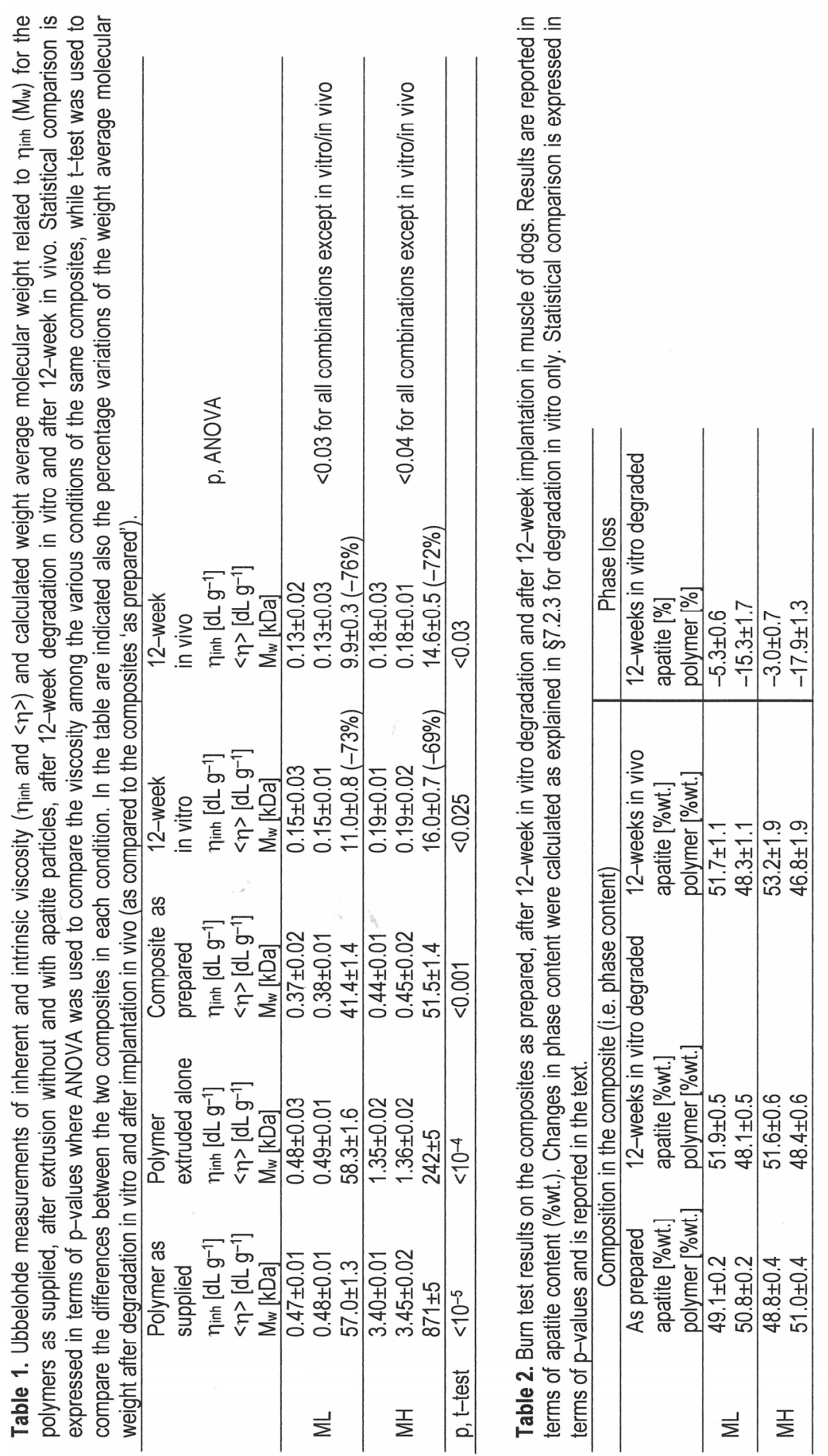


Table 3. Percentage of covering perimeter (\%pt.) and thickness of apatite layers onto the surface of the two materials (as evaluated from BSEM images) in their starting conditions, after two days in SBF, after 12week degradation in vitro (SPS) and after three months implantation in muscle of dogs. For completeness, in brackets are reported the percentage variations respect to the starting conditions of layer thickness (calculated on the final average measured values). Statistical comparison is expressed in terms of $p$-values in the text.

\begin{tabular}{lllll}
\hline & As prepared & 2-days SBF & $\begin{array}{l}\text { 12-weeks } \\
\text { in vitro }\end{array}$ & $\begin{array}{l}\text { 12-weeks } \\
\text { in vivo }\end{array}$ \\
\hline ML & & & & \\
- perimeter [\%pt.] & $73.9 \pm 8.5$ & $86.5 \pm 6.4$ & $67.3 \pm 10.5$ & $84.9 \pm 5.9$ \\
- thickness [ $\mu \mathrm{m}]$ & $11.7 \pm 2.8$ & $29.1 \pm 6.2(+148.8 \%)$ & $10.2 \pm 2.7(-12.8 \%)$ & $32.6 \pm 6.2(+178.3 \%)$ \\
\hline MH & & & & \\
- perimeter [\%pt.] & $74.8 \pm 7.6$ & $86.3 \pm 5.0$ & $69.6 \pm 8.3$ & $85.5 \pm 8.3$ \\
- thickness [ $\mu \mathrm{m}]$ & $10.4 \pm 2.3$ & $22.8 \pm 4.7(+119.3 \%)$ & $9.1 \pm 3.2(-12.7 \%)$ & $19.0 \pm 4.0(+83.1 \%)$ \\
\hline
\end{tabular}
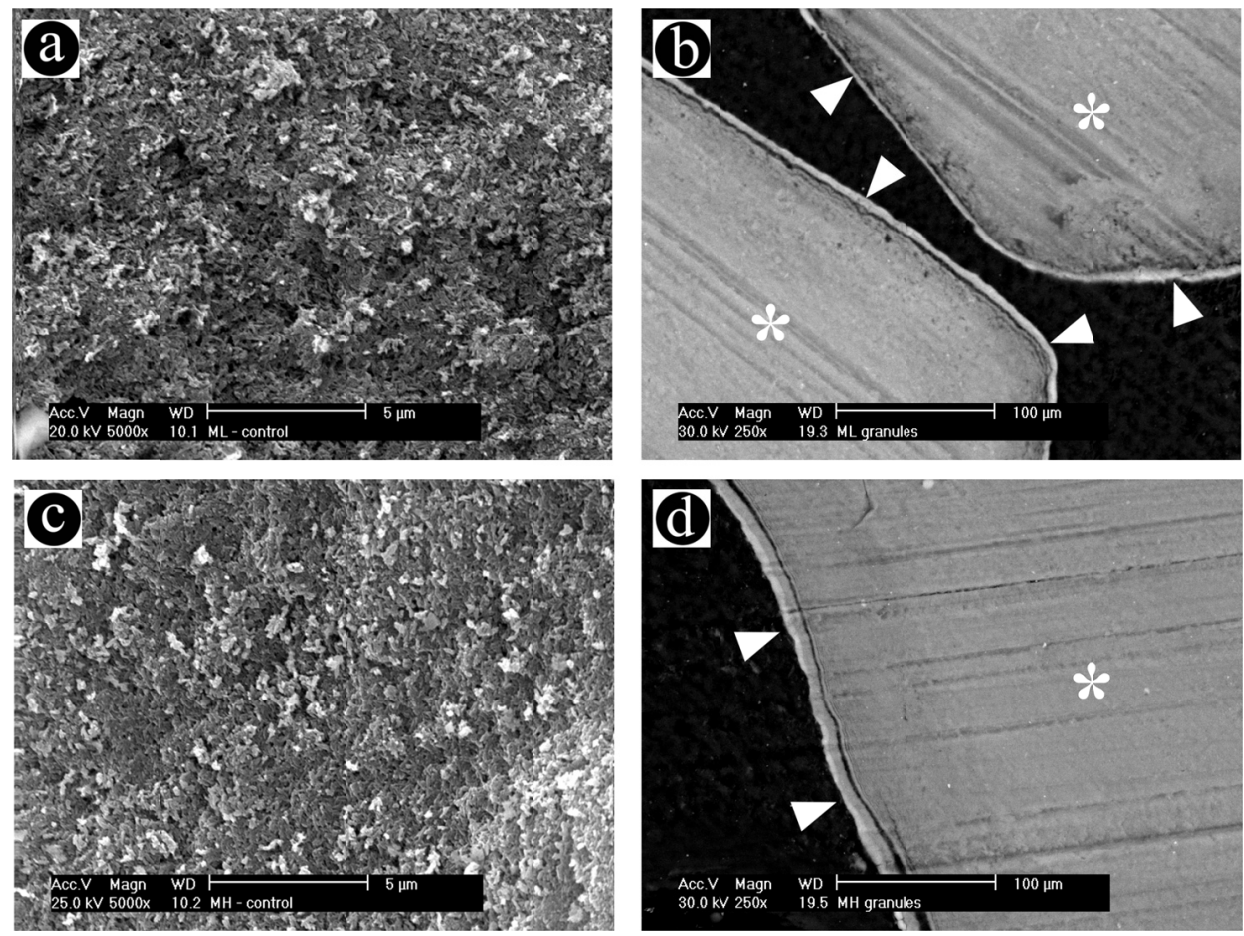

Figure 2. SEM images showing the similarity between the surface of (a) ML and (c) MH granules. BSEM images of cross-sections of the starting surface of (b) ML and (d) MH granules. Alkali treatment caused partial removal of polymer from the surfaces and exposed apatite particles generating calcium phosphate apatite layers (white triangles) surrounding the granules of both materials. Homogeneous cores were seen in both materials $\left(^{*}\right)$. 
Table 4. Calcium and phosphate cumulative ion concentrations, mass loss and fluid uptake after 12 weeks in vitro degradation. Differences between $\mathrm{ML}$ and $\mathrm{MH}$ were significant only for fluid uptake, but not for all other measurements.

\begin{tabular}{lllll}
\hline & $\begin{array}{l}\text { Calcium release } \\
{[\mu \mathrm{M}]}\end{array}$ & $\begin{array}{l}\text { Phosphate release } \\
{[\mu \mathrm{M}]}\end{array}$ & $\begin{array}{l}\text { Mass loss } \\
{[\%]}\end{array}$ & $\begin{array}{l}\text { Fluids uptake } \\
{[\%]}\end{array}$ \\
\hline $\mathrm{ML}$ & $504 \pm 26$ & $170 \pm 5$ & $10.4 \pm 0.8$ & $17.4 \pm 2.5$ \\
\hline $\mathrm{MH}$ & $549 \pm 43$ & $179 \pm 5$ & $10.8 \pm 0.4$ & $10.2 \pm 2.0$ \\
\hline p. t-test & $>0.3$ & $>0.15$ & $>0.45$ & $<0.02$ \\
\hline
\end{tabular}
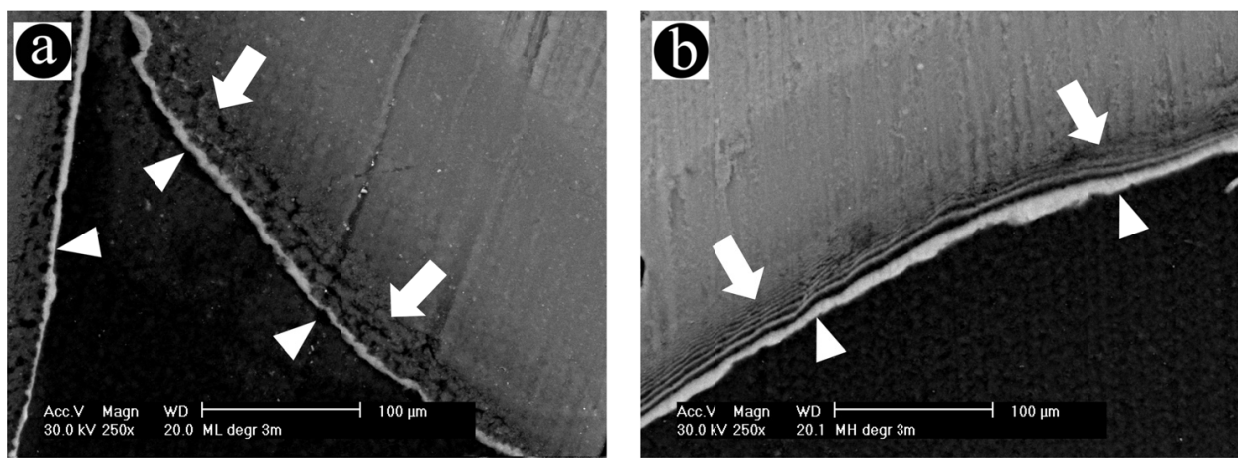

Figure 3. BSEM images of (a) ML and (c) MH granules showing their bulk and surrounding apatite layers (triangles) after 12-week degradation in vitro. Homogeneous cores were still seen in both materials, however the external edge of the granule appear degraded in both materials.
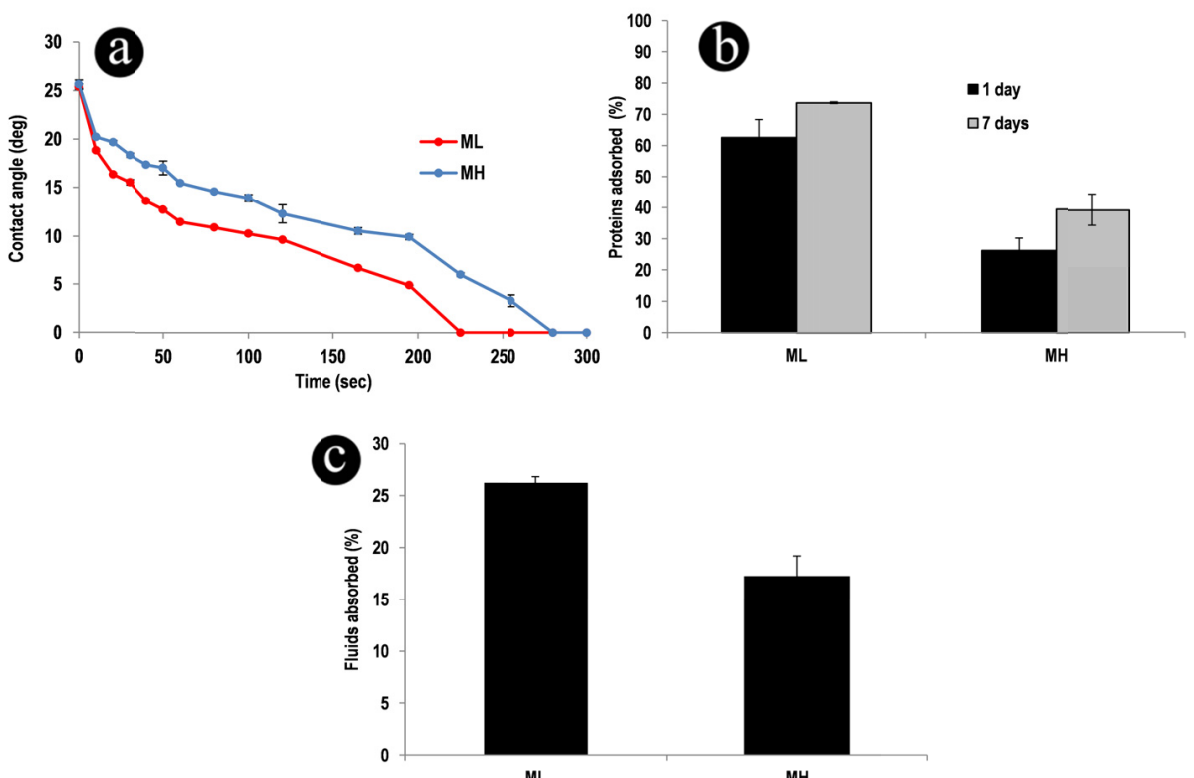

$\mathrm{MH}$

Figure 4. (a) Dynamic contact angle changes for the two composites observed up to 5 minutes. Significant differences were observed over time. (b) Serum proteins adsorbed from $0.1 \%$ FBS solution onto the surface of the composites after one and seven days. Significant differences were always seen between the two materials. (c) Significant different fluid uptake from $0.1 \%$ FBS solution was observed after seven days in the two materials. Statistical comparison is expressed in terms of $p$-values and is reported in the text. 
a

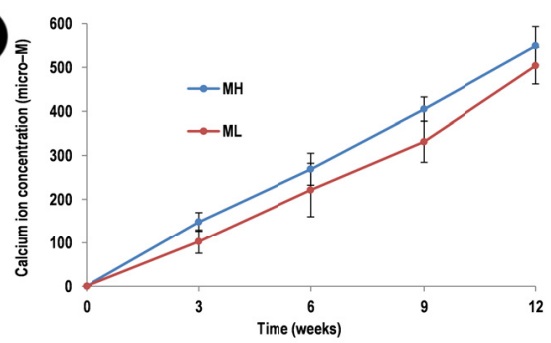

b

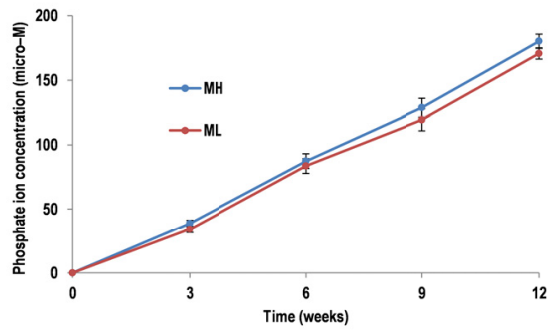

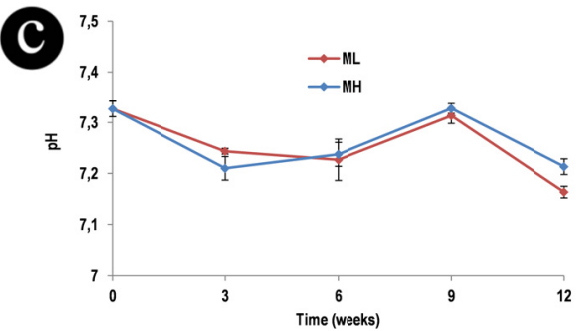

Figure 5. (a) Calcium and (b) phosphate ion (measured) cumulative concentration in SPS where the two composites were soaked for 12 weeks. No significant differences were observed between the two materials at every time point $(p>0.1)$. (c) $\mathrm{pH}$ variations of SPS over three months. No significant differences in $\mathrm{pH}$ between the two materials were observed until week $9(p>0.06)$. At week 12 the $\mathrm{pH}$ was different $(p<0.011)$, however this difference did not affect the overall degradation.

\subsubsection{In vitro surface mineralisation in simulated body fluid (SBF)}

After immersion in SBF, both composites showed surface mineralisation within two days as indicated by layers with spherical globules where apatite had spontaneously nucleated. The mineralised surfaces had similar nano-topography in both composites (Figure 6a,c). After mineralisation, the composites had a more nano-structured surface texture than their starting counterparts. Observations at BSEM showed thicker apatite layers compared to the starting granules (Figure 6b,d), indicating that calcium phosphate had precipitated from SBF and nucleated onto the initially exposed apatite particles. Compared to the starting conditions, significant increases in thickness $\left(p<10^{-5}\right.$ for both $M L$ and $M H$ ) and covered perimeters ( $p<0.002$ for both $M L$ and $M H$ ) were measured in both materials (Table 3), demonstrating that surface mineralisation occurred. Interestingly, significantly thicker layers were measured on $\mathrm{ML}$ compared to $\mathrm{MH}$ $(p<0.025)$ although the surface covering was similar $(p>0.93)$. 

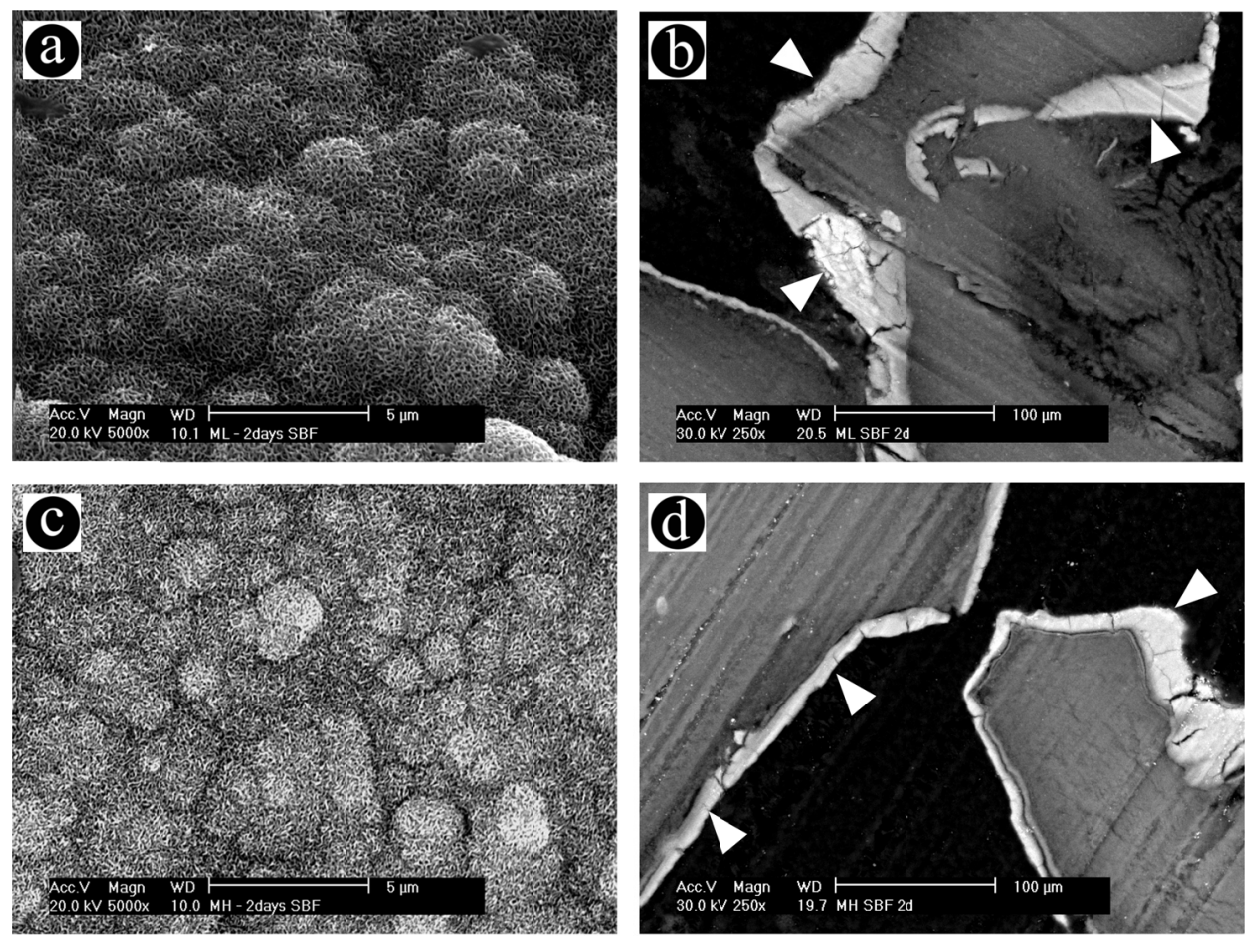

Figure 6. SEM images of mineralised surfaces of (a) ML and (c) MH granules after two days in SBF. Nanostructured surface texture could be observed on both composites. BSEM images of cross-section of (b) ML and (d) MH granules after two days in SBF. White triangles indicate the apatite layers around the granules, which were thicker compared to the starting controls. This indicates that calcium phosphates have precipitated from SBF on both materials.

7.3.5. Protein adsorption and fluid uptake from $0.1 \%$ foetal bovine serum (FBS) solution Serum proteins could be adsorbed from $0.1 \%$ FBS solution onto the surface of the two composites. In particular, $\mathrm{ML}$ adsorbed significantly more proteins than $\mathrm{MH}(\mathrm{p}<0.002)$ already after one day (Figure 4b). Only a small increase in the adsorbed proteins was observed after seven days, probably because after the first day most of the surface binding sites were already occupied. Interestingly, ML could take up significantly larger amounts of fluid from $0.1 \%$ FBS solution than $\mathrm{MH}$ within one week $(p<0.015)$ (Figure 4c). The higher fluid uptake in ML may have facilitated the contact between its surfaces and FBS, increasing the probability of serum protein adsorption.

\subsubsection{Animal experiment}

Six samples of each composite were intramuscularly implanted in six dogs, and after 12 weeks all samples were retrieved. The explants were surrounded by thin layers of connective tissue and muscle. Histological observations demonstrated that very limited bone formation was triggered in all ML implants (6 out of 6 ) but in none of MH samples 
( 0 out of 6 ). Mature bone formed tightly to the mineralised surfaces of ML granules, while non-mineralised bone matrix, with active osteoblast-like cells, was observed on the outer surface of the mature bone (Figure 7). These results indicated that the process of bone formation was still active after 12 weeks of implantation. The fact that mature bone grew tightly onto the mineralised apatite layers was confirmed by BSEM images taken in the same spots used for histology (Figure 8a,c).
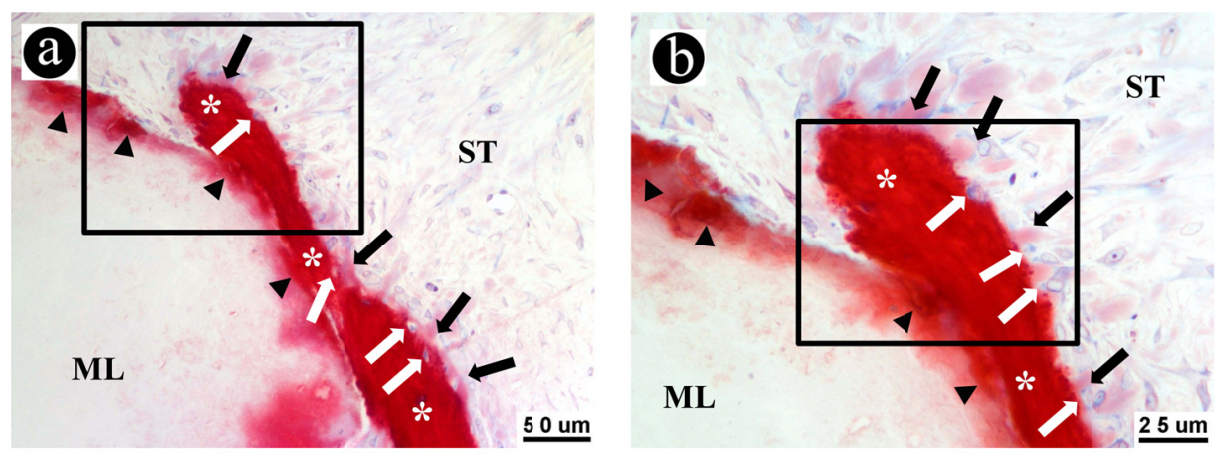

Figure 7. Histology images (non-decalcified, $1 \%$ methylene blue and $0.3 \%$ basic fuchsin staining) of ML explant harvested from back muscle of dogs after 12 weeks. Image (b) is the magnification of the box in image (a). Heterotopic bone formation was induced and an active, but not yet mineralized, bone formation zone (long black arrows) is visible. Osteoblasts (long white arrows) are embedded in bone matrix and are synthesising new bone. The inner part of the bone is an immature woven and mineralized tissue (white stars). Surface mineralisation occurred (black triangles) and bone tightly formed onto these mineralized layers. Soft tissues (ST) and bulk of the material (ML) are indicated as well. The box in (b) indicates the spot where BSEM images have been taken (Figure 8c).

As compared to the starting materials, thicker apatite layers surrounding the granules of both composites could be observed (Figure 8). This suggests that calcium phosphates may have precipitated from body fluids and nucleated onto the granule surfaces. A significant increase in thickness ( $p<10^{-5}$ for both $\mathrm{ML}$ and $\mathrm{MH}$ ) and covering perimeter $(p<0.004$ and $p<0.008$ for $\mathrm{ML}$ and $\mathrm{MH}$ respectively) were measured demonstrating that surface mineralisation took place in vivo (Table 3). Significantly thicker layers formed in vivo on $\mathrm{ML}$ as compared to $\mathrm{MH}\left(\mathrm{p}<10^{-5}\right)$, but the perimeter of surface covering was similar in the two materials ( $p>0.85$ ), confirming the observed in vitro trends (Table 3 ). Overview BSEM images showed that bulk erosion occurred and generated porous implants in both materials (Figure 8). Inherent viscosity measurements demonstrated that hydrolysis of the polymer phase occurred in vivo for both materials (Table 1) and, after explanting, the two composites still presented significant different weight average molecular weights. Interestingly, the molecular weights after 3-months in vitro degradation and in vivo implantation were similar (Table 1). Further, comparing the final phase composition of ML and MH explants (Table 2), no differences were seen ( $p>0.3$ ) demonstrating that their overall degradation was similar, as observed also in vitro over 
the same period length. These facts indicate that in vivo the materials may have degraded similarly to the trend indicated by the in vitro degradation experiment. Since the apatite layers after three-months in vitro degradation decreased (due to apatite dissolution), this indicates that no apatite particles were further exposed by the degradation of the material (Table 3). This last fact strengthens the results on in vivo mineralization mentioned earlier. Concluding, the different increase in thickness of the apatite layers on the two composites is not due to a possible increase in apatite particles exposure caused by the degradation process, but to precipitation of apatite from the surroundings.
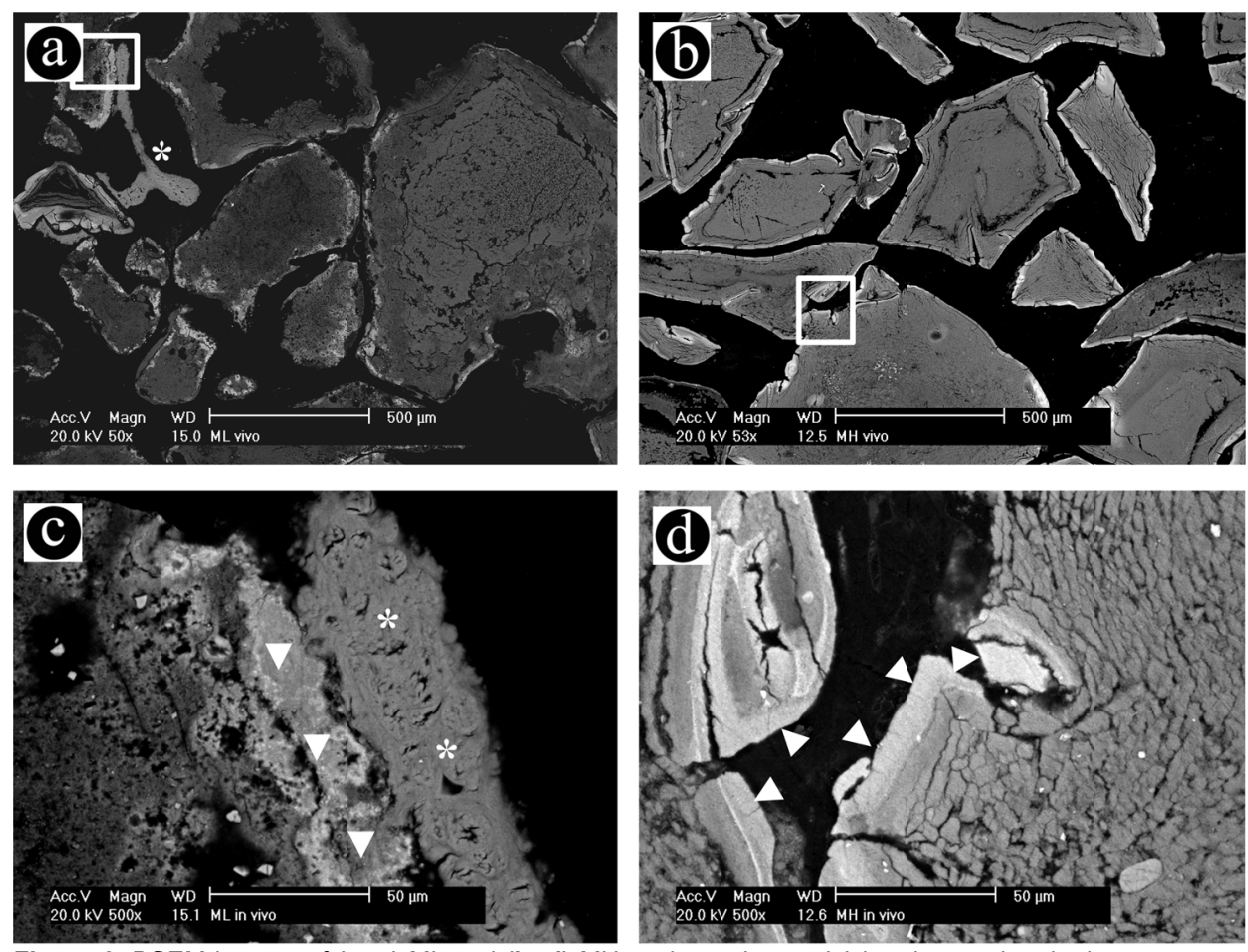

Figure 8. BSEM images of $(a, c) M L$ and $(b, d) M H$ explants. Image (c) has been taken in the same spot shown in the box in Figure $7 \mathrm{~b}$. Bone formed in ML sample (white stars), while layers of surface mineralisation are clearly visible (white triangles) in both materials. These layers are thicker than the starting granules, meaning calcium phosphates precipitated from body fluids and nucleated onto the materials surfaces. Importantly, bone is tight to the mineralized layers around ML surface (c). It is interesting that the bulk of the two materials appear degraded. The white boxes in (a) and (b) indicate the spots shown in (c) and (d) respectively. 


\subsubsection{Dynamic mechanical analysis}

As expected, the recorded storage modulus was significantly higher in the composite containing high molecular weight polymer, i.e. $\mathrm{MH}$, and at the same time the loss tangent was lower (Figure 9). The modulus increased (not significantly) but the loss tangent significantly decreased with the frequency for both materials indicating that the polymers had stiffening behaviours. Presumably the increasing loading rate hindered the molecular chains relaxation to their neutral conformation between the loading cycles, consequently requiring more stress for the same strain.
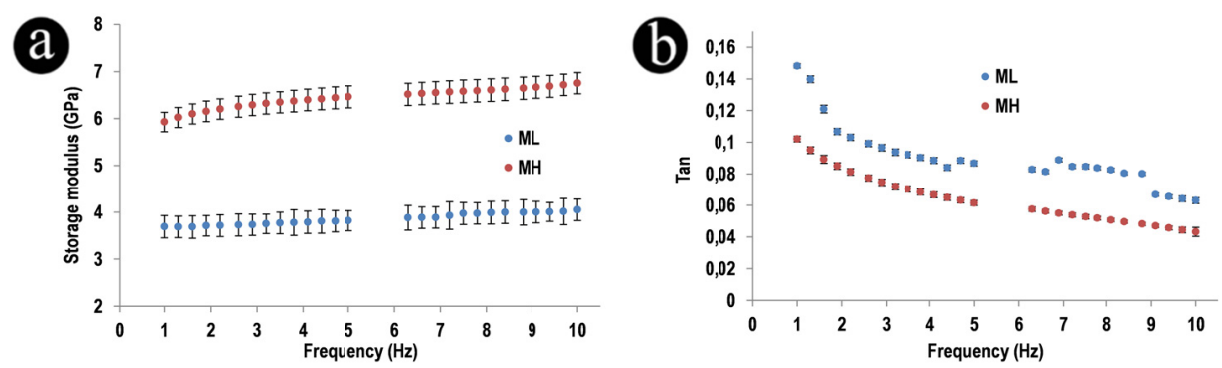

Figure 9. Recorded (a) storage modulus and (b) loss tangent of $\mathrm{ML}$ and $\mathrm{MH}$. The measurements were performed on dry samples in dry air at $37^{\circ} \mathrm{C}$.

\subsection{Discussion}

Herein we have shown that poly $(\mathrm{D}, \mathrm{L}-$ lactide $)$ molecular weight influences the bone forming ability of its composites with calcium phosphate apatite, where only the low molecular weight polymer containing implants (i.e. ML) triggered limited heterotopic bone formation. The molecular weight of the polymer in composites therefore appears to play a role in initiating osteoinduction.

After a 12-week period in saline physiological solution (SPS) we observed higher fluid uptake in ML than MH (Table 4). In this case, liquid absorption in the composites is correlated with the molecular weight of the polymer phase. It is noticeable that polymers which take up large amount of fluids degrade faster than those absorbing small amounts of fluid because hydrolysis is favoured. ${ }^{[349,350]}$ Assuming that low molecular weight polymers degrade, it has been suggested that composites of low molecular weight poly $(D, L-l a c t i d e)$ with $40 \%$ wt. apatite content release sufficient amounts of calcium ions favouring osteoinduction (see Chapter 3 of this thesis). In fact, such ions are believed to be signalling molecules for bone cells[226-228, 252] and may also enhance surface mineralisation. ${ }^{227,}{ }^{228,}{ }^{324]}$ Besides calcium ions, it has been recently reported that phosphate ions also support surface bio-mineralisation. ${ }^{[253]}$ Putting together the aforementioned assumptions, one may connect bone formation in $\mathrm{ML}$ with the faster bulk hydrolysis of its polymeric phase. In fact, hydrolysis will cleave the polymer chains degrading the composite matrix and exposing apatite particles to the absorbed fluids, 
which would dissolve them facilitating the release of calcium and phosphate ions. However, during a 12-week period our results showed similar mass loss and molecular weight changes (in percentage), and comparable ions release profiles in vitro for the two materials as well as equivalent post-degradation phase contents (i.e. similar phase loss trends, Table 2). Further, after 12 weeks intramuscular implantation in dogs, no significant differences were found in the molecular weight of the polymers in $M L$ and $M H$, indicating similar degradation behaves in vivo. This may be explained by the time course of the study (i.e. 12 weeks), which may have been too short to allow the penetrated fluids to fully hydrolyse the polymer and degrade the bulk of the composites leading to insignificant differences in the degradation patterns of the two materials. Hydrolysis may have been restrained by the buffering effect of calcium and phosphate ions on the acidity provoked by the formation of polymer residuals. From these results, we can conclude that, under the conditions of this 12-week period, the degradation of the two composites was not dependent on their different fluid uptakes.

Further to this, the difference in osteoinductive potential of the two composites is not likely due to ion release. In fact, our results showed that the in vitro degradation model may be used as indication of the possible in vivo degradation trends. So, the two composites may have degraded similarly releasing comparable amounts of ions.

We observed that ML had higher fluid uptake after seven days soaking in foetal bovine serum (FBS) solution and could adsorb significantly more serum proteins than $\mathrm{MH}$ (Figure 4b, 3c). In our situation, the higher fluid uptake in ML within short time could enhance the contact between its surfaces and FBS, increasing the probability of serum protein adsorption. Our observations support the conclusion that, in vivo, these biological molecules could have more pronouncedly been adsorbed on the surfaces of ML. As already suggested in literature, ${ }^{[154,228,251,346]}$ such adsorbed bio-molecules provide better conditions for (stem) cell colonisation and osteogenic differentiation that finally leads to bone matrix synthesis. The increased fluid uptake in ML, which may have facilitated the contact between the surrounding fluids and the composite surfaces, also enhanced apatite nucleation from the fluids. Besides this, the high apatite content in composites could favour the nucleation of mineralised layers onto its surfaces and thereby generating conditions that allow cells to synthesize bone. ${ }^{[234,248,249]}$ We observed in vitro surface mineralisation on both $\mathrm{ML}$ and $\mathrm{MH}$ composites within two days, where similar three-dimensional nano-structured layers were generated (Figure 6). However, the formation of mineralized layers was faster on $\mathrm{ML}$ than $\mathrm{MH}$ as shown by the larger increase in thickness. Similarly, mineralisation occurred in vivo on both materials, where $\mathrm{ML}$ mineralised quicker than $\mathrm{MH}$, generating thicker nucleated apatite layers (Table 3). Nano-scaled structures containing calcium can expose more binding sites for biomolecules adsorption [153, 154, 250] Thus, the formation of thicker three-dimensional nano-structured mineralised layers in $\mathrm{ML}$, together with the higher fluids absorption 
ability of ML, could have allowed larger protein adsorption onto ML. Even if no differences were observed in the mineralization potential of $M L$ and $M H$, the similar nano-texture on their mineralized surfaces would improve the initial anchorage of cellular filopodia[152, 195] as compared to non-surface mineralizing materials.

The initial inflammatory response to the implantation of biomaterials has been proposed as a trigger for osteoinduction as well. Osteoclastogenesis and osteoblastogenesis at the biomaterial surface may be mediated by macrophage adhesion and subsequent secretion of cytokines. Histological observations over time demonstrated that, upon implantation of ceramics, fibrous tissue containing monocytes and macrophages invaded the implants at early time points, while later bone formed tight to the material and active osteoblasts were aligned with the newly synthesised bone.[218-220] Interestingly, the secretion of cytokines such as interleukin-6 (IL-6) and prostaglandin E2,[217, 386] were enhanced when macrophages were cultured on materials having micro-textures compared to smooth surfaces, ${ }^{[255]}$ and the presence of IL-6 enhanced the expression of osteogenic markers (e.g. alkaline phosphatase and osteocalcin) from osteoblasts.[256] Unpublished preliminary in vitro results of members from our group showed that the culture of murine monocyte/macrophage cell line RAW 264.7 on osteoinductive ceramic resulted in significantly higher levels of secreted IL-6 and IL-4, cytokines responsible for osteoclastogenesis and foreign body giant cell fusion respectively, when compared to a non-inductive ceramic. Other data showed that osteoclastic markers in murine macrophage cell line $\mathbf{J} 774.2$ were significantly up-regulated during culture on osteoinductive ceramics, and stimulation of RAW 264.7 with osteoclast differentiation factor RANKL (receptor activator of NF-KB ligand) during culture on osteoinductive ceramics resulted in larger, more surface integrated osteoclast-like cells. So, by uptaking more fluids, ML could generate thicker nano-rough mineralised surfaces within few days upon implantation which further enhanced bio-molecule adsorption. Thus, more attractive conditions for macrophages colonisation may have been created on ML, and it could be that such cells may have induced to secrete various cytokines and angiogenic molecules ${ }^{[27]}$ later triggering the differentiation of stem cells into an osteogenic line and leading later to bone matrix synthesis in ML.[217] However, further evaluation of these macrophage/osteoclast culture systems may shed light on the potential osteogenic effects that such cell-material interactions may have on precursor cells.

In summary, the molecular weight of poly(D,L-lactide) composites can indirectly control surface phenomena occurring at the interface that will ultimately determine whether osteoinduction takes place or not. Composites with low molecular weight polymer (i.e. $\mathrm{ML}$ ) absorbed more body fluids and activated a cascade of surface events. Serum proteins were taken up and the formation of thicker nano-structured mineralised surfaces may have allowed for even higher amounts of protein adsorption. As a 
consequence, improved cell colonisation on the nano-structured mineralised surface may have led to heterotopic bone formation through the adsorbed protein motifs. Further to this, inflammatory response with the activation of macrophages could have played roles as well in triggering osteoinduction. It is interesting to note that in vivo bone formation occurred after surface mineralisation, which highlights the importance of surface bioactivity. This supports the suggestion that surface mineralisation is a necessary condition, ${ }^{[228,234]}$ even if it is not the driver, for heterotopic bone formation in composites.

However other intrinsic characteristics of the polymer phase, such as its monomer content and crystallinity, cannot be excluded from the discussion. As already mentioned in Chapter 6, the monomer content can increase due to the extrusion and it facilitates the polymer hydrolysis. $[336,411]$ In particular, it was reported that after extrusion of $96 \% \mathrm{~mol}$. L-lactide $/ 4 \% \mathrm{~mol}$. D-lactide copolymer with increasing initial inherent viscosity, the monomer content increased and was higher for the copolymer having higher initial viscosity. ${ }^{[336]}$ It could be that, in this study, the final monomer content in the two composites was different, and it could have some role in determining their final characteristics. However, different working conditions (e.g. the monomer chemistry is different, the polymer was extruded with $50 \%$ wt. apatite) render impossible to draw any conclusion or comparison with the mentioned literature references. It is therefore advisable to consider the monomer content in future studies as it may have crucial roles in the biological response of the materials. The manufacturing process may also influence the polymer crystallinity, which affects fluid uptake, degradation and mechanical properties ${ }^{[387]}$ with implications on the biological performances of the materials. In particular, it has been reported that the polymer crystallinity affects the cell response to the biomaterial surface. ${ }^{[412,413]}$ Again, no conclusion can be drawn and thus it is recommended to consider also the polymer crystallinity in future experiments.

\subsection{Conclusion}

From these results, we can conclude that the key point in tissue regeneration is a proper design of materials by choosing appropriate physicochemical characteristics. In this way surface properties can be determined to control the in vivo cellular fate. For example, in cartilage or muscle regeneration, materials with surfaces that can mechanically stimulate, at local level, the surrounding cells might control the cellular differentiation and thus their fate into chondrocyte- or myoblastic-lines. ${ }^{[9-103,352]}$ However, we also observed that improving the osteoinductive property by virtue of controlling the polymer molecular weight did not lead to materials with sufficient mechanical properties. In fact, osteoinduction was obtained at the cost of elastic properties worsening. This tells us that there is need of a balance between the various material factors to obtain proper tuning of both mechanical characteristics and osteoinduction. 


\section{ADDENDUM}

\section{7a.1. Introduction}

As seen in 7.3.7. the osteoinductive composite containing poly(D,L-lactide) had low stiffness and its damping properties were not stable over the frequency sweep. Thus, a separated and independent study has been performed using $70 \% \mathrm{~mol}$. L-lactide $/ 30 \% \mathrm{~mol}$. $D, L-l a c t i d e$ copolymer as organic phase of the composites. This polymer is expected to have higher mechanical,performances thanks to the higher L-lactide content, and to be sufficiently degradable to allow osteoinduction thanks to its $D, L-l a c t i d e$ component. To evaluate their osteoinductive potential, a different animal model has been used for longer implantation period (i.e. 6 months in sheep). As explained in Chapter 6, a 5-week accelerated degradation study at high temperature has been done to simulate a longterm degradation at physiological temperature. The results herein presented confirmed the conclusions previously described in this Chapter.

\section{7a.2. Materials and methods}

\section{7a.2.1. Preparation and characterization of composites}

The used apatite powder was the same of the one described in $\S 7.2 .1$. Copolymers of $70 \%$ mol. L-lactide $/ 30 \%$ mol. D,L-lactide with different molecular weights (declared inherent viscosity $3.85 \mathrm{dL} \mathrm{g}^{-1}$ with residual monomer $<0.5 \%$, and $5.95 \mathrm{dL} \mathrm{g}^{-1}$ with residual monomer $<0.1 \%$, PLDL38 and PLDL60 respectively; Purac Biomaterials BV, Gorinchem, the Netherlands) were extruded with the apatite powder to make dense composites (50/50\%wt.). Extrusion had been done following the protocol described in $\S 5.2 .2$. at the temperatures of $195 \pm 1^{\circ} \mathrm{C}$ and $205 \pm 1^{\circ} \mathrm{C}$ when, respectively, PLDL38 and PLDL60 were used. The two resulting composites will be named as M38 and M60 respectively. Granules and bars were prepared and surface treated $(1 \mathrm{M} \mathrm{NaOH})$ and then sterilized with ethylene oxide (\$5.2.2). The composites were chemically characterized with XRD and their surface topography was observed at SEM as described in §7.2.2. Burn test (§5.2.2) was performed to estimate the phase content in the two composites. The intrinsic viscosity of the polymer phase was measured as described in in \$7.2.2.

\section{7a.2.2. Protein adsorption of composites}

The potential to adsorb serum proteins from serum and to uptake fluids has been evaluated following the same procedure reported in $§ 7.2 .5$.

\section{7a.2.3. Accelerated in vitro degradation}

To predict the long-term degradation behaviour of polymer-based materials in the body, in vitro accelerated degradation tests at high temperature may be used. ${ }^{[353]}$ It has been 
recommended that such tests, to be valid, should be performed at temperatures lower than the glass transition temperature (i.e. $\mathrm{T}_{\mathrm{g}}$ ) of the considered polymer to avoid unwanted effects due to polymer state transitions. ${ }^{[354-357,368]} \mathrm{A}$ phosphate buffered saline (PBS; Invitrogen, Darmstadt, Germany) solution having initial pH of $7.5 \pm 0.05$ was used. Sterile granules of each composite $(75 \pm 0.5 \mathrm{mg})$ were carefully weighed before use $\left(\mathrm{m}_{0}\right)$ and soaked in $30 \mathrm{~mL}$ PBS at $55 \pm 0.5^{\circ} \mathrm{C}$ for five weeks. The temperature was set referring to the polymers $T_{g}$ of the copolymers used here (i.e. $55-60^{\circ} \mathrm{C}$ ). For each of the three time points considered, i.e. 1, 3 and 5 weeks, three samples of each material were used. Every day the $\mathrm{pH}$ of the degrading solution was recorded with a $\mathrm{pH}$-meter (Orion 4 Star, Thermo Scientific, USA) and the medium was refreshed in case the $\mathrm{pH}$ fell below 7.0. With the solution removed at every refreshment, the amounts (in $\mu \mathrm{M}$ ) of calcium and phosphate ion released from the samples were measured using appropriate biochemical kits (QuantiChrom ${ }^{T M}$ Calcium assay kit, BioAssay Systems, USA; PhosphoWorks ${ }^{\mathrm{TM}}$ Colorimetric Phosphate Assay kit Blue Color, Bioquest Inc, USA) with the help of a spectrophotometer (AnthosZenyth 3100, Anthos Labtec Instruments $\mathrm{GmbH}$, Salzburg, Austria) and absorbance filter of $620 \mathrm{~nm}$ for both assays. At each of the considered time points, i.e. 1, 3 and 5 weeks, the granules were removed from the degrading media, the excess PBS was wiped away and their wet weight was carefully weighed $\left(m_{\text {wet }}\right)$. Afterwards they have been vacuum-dried at room temperature until their weight was stable and then were weighed again $\left(m_{\text {dry }}\right)$. The mass loss and fluid uptake of the composites was determined as:

mass loss $=100 \cdot\left(m_{0}-m_{\text {dry }}\right) / m_{0}$ fluid uptake $=100 \cdot\left(m_{\text {wet }}-m_{\text {dry }}\right) / m_{\text {dry }}$

Part of the degraded samples were then was heated at $900^{\circ} \mathrm{C}$ to burn the polymer phase out and determine the final effective apatite and polymer percentage contents (in \%wt., $p_{\mathrm{ap}}$ and $\mathrm{p}_{\mathrm{pol}}$ respectively). The remaining part of the samples was dissolved in chloroform (Sigma-Aldrich) and, after separating apatite from the polymer, we determined the intrinsic viscosity $(\langle\eta\rangle)$ using an Ubbelohde viscometer as explained in §7.2.2. As already mentioned in Chapter 6 (i.e. \$6.2.5. for theory background), to evaluate the hydrolysis rate of the polymer phase in the two composites we estimated the autocatalysed hydrolytic degradation rate constant $k$ as:

$k \cdot t=-\ln \left(\left\langle\eta_{0}\right\rangle \mid\langle\eta\rangle\right)$

where $\left\langle\eta_{0}\right\rangle$ is the initial intrinsic viscosity and $\langle\eta\rangle$ is the intrinsic viscosity at the considered time point $t(t=0,7,21$ and 35 days) for the considered polymer phase. For convenience, the results were plotted on a graph $\ln \left(\left\langle\eta_{0}\right\rangle \mid\langle\eta\rangle\right)$ against time $t$ (in days).

7a.2.4. Dynamic mechanical analysis

It has been done following the protocol described in \$7.2.7. 


\section{7a.2.5. Animal study}

To evaluate the in vivo biological response, granules of the two composites were intramuscularly implanted in five sheep for six months (with the permission of the local animal care committee: Animal Center, Sichuan University, Chengdu, China; protocol \#P11030). The surgery procedure (but no fluorescent injections were done) and the histological analysis were similar to those described in Chapter 2 (\$2.2.4 and §2.2.5). Unfortunately, no sample was kept for degradation analyses (e.g. burn test and viscosity measurements).

\section{7a.3. Results}

7a.3.1. Preparation and characterization of composites

Extrusion process, as expected, significantly decreased the intrinsic viscosity of both polymer phases, and the addition of apatite further decreased it (Table 5). The two final materials still had significant different intrinsic viscosity. The composites had similar surface chemistry (in terms of apatite and monomer chemistry) as demonstrated by XRD patterns (Figure 10) and, from past experience (described in other Chapters of this thesis), it was expected that they also had the similar bulk chemistry. As resulted from the burn test, they had similar starting phase composition (Table 6). Their surface topography was similar, with randomly disordered texture due to the alkali treatment (Figure 10).
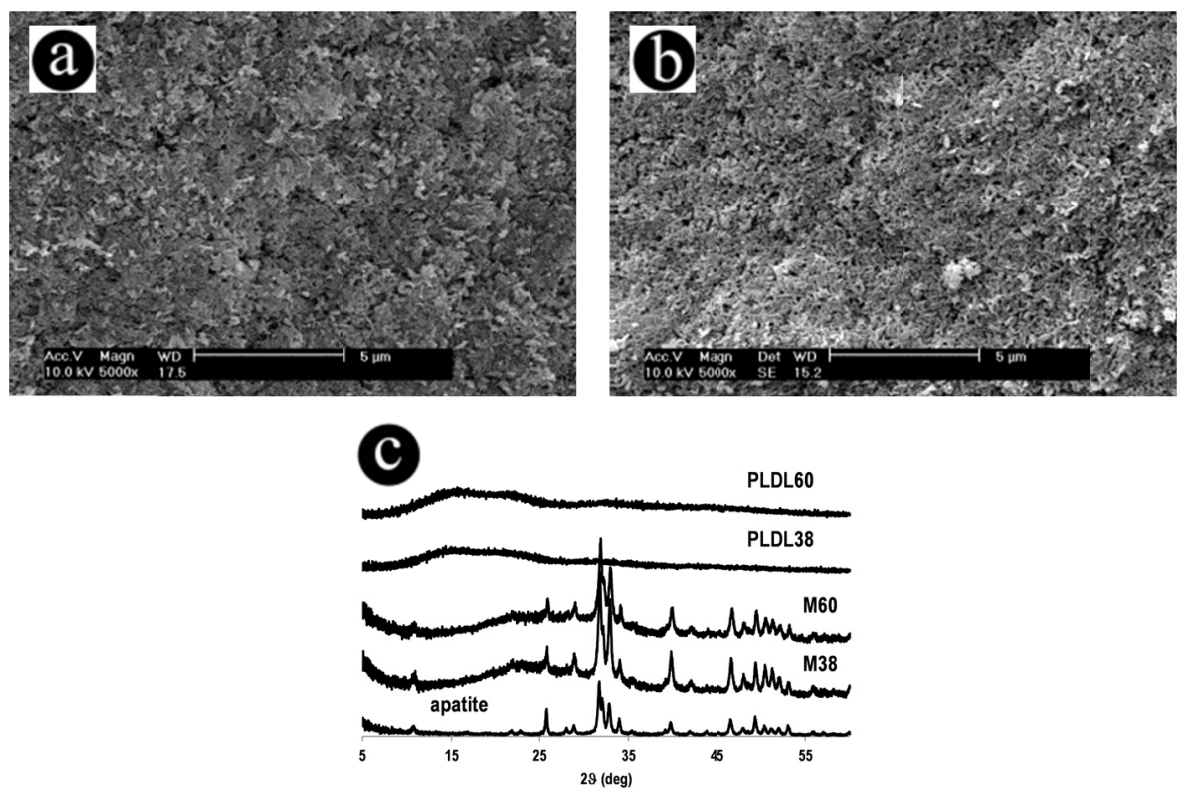

Figure 10. (a) and (b) are SEM images of the surface of M38 and M60 respectively. Similar randomly disordered surface topographies between the two composites are visible. (c) XRD spectra for the copolymers, apatite and composites. It may be observed that the composites have almost identical patterns. 


\section{7a.3.2. Protein adsorption of composites}

Serum fluid was absorbed in larger amounts by M38 than M60 $\left(p<10^{-4}\right)$ and this fact may have enhanced the adsorption of serum proteins onto M38 $\left(p<10^{-3}\right)$ (Figure 11). Over time the amount of absorbed serum and adsorbed proteins did not significantly change in both materials.
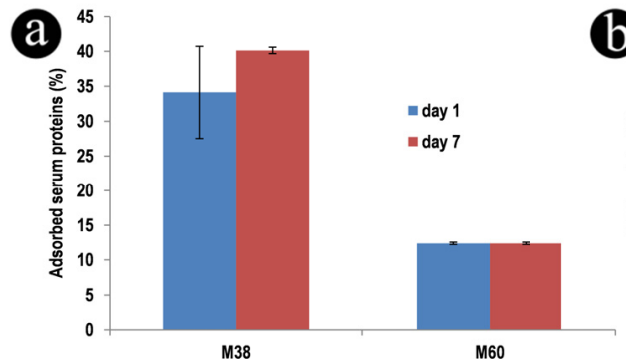

Figure 11. (a) Significant differences in serum proteins adsorption (from $0.1 \% \mathrm{FBS}$ ) were always seen between the two materials after one and seven days. (b) Significant different amounts of FBS fluid were absorbed already after one day, when the materials reached their maximal capacity to absorb fluids (after seven days there was no significant increase in fluids content in both composites). Statistical comparison is expressed in terms of $p$-values and is reported in the text.

\section{7a.3.3. Accelerated in vitro degradation}

Both composites degraded during the whole considered period (i.e. 5 weeks) as indicated by their mass loss (Figure 12) and continuous release of calcium and phosphate ions (Figure 13). As expected, the material containing the lower molecular weight copolymer had faster mass loss and higher ion release. The difference, even if significant, in mass loss was not large, most likely due to the small difference in the starting intrinsic viscosity of the polymer phase (Table 5). Consistently, there was a direct link between mass loss and fluid uptake (Figure 12), where the larger mass loss corresponded to a large fluid uptake and vice versa. Faster decline in intrinsic viscosity was observed in M38 composites (Table 5), which was confirmed by the autocatalysed hydrolytic degradation rate constants (Figure 14) where M38 had lower constant than $\mathrm{M60}$. The high correlation factors validate the model for this study (Figure 14). The $\mathbf{p H}$ of the medium was measured daily, and we observed it had an average slow decrease of about -0.05 per day, which justifies the model used to evaluate the hydrolysis considering the autocatalysis (as explained in §6.2.5. of Chapter 6). We observed that, over time, the apatite and polymer phase contents significantly changed compared to the starting conditions (Table 6) with decreasing apatite content. This fact might be connected with the observed decreasing $\mathrm{pH}$, which may have favoured the dissolution and/or release of whole apatite particles (mechanism proposed also in Chapter 4 for M25 composite). 

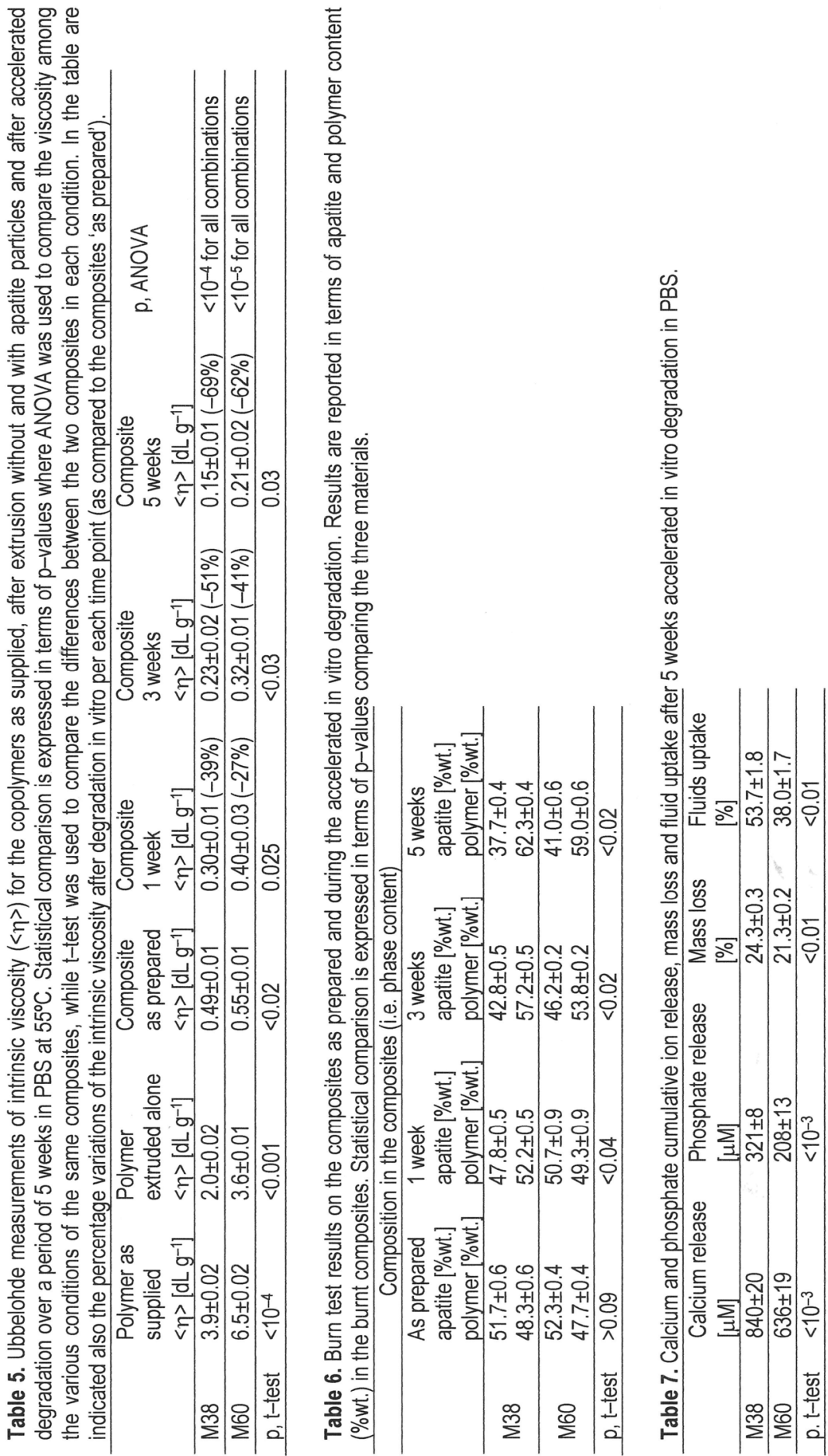

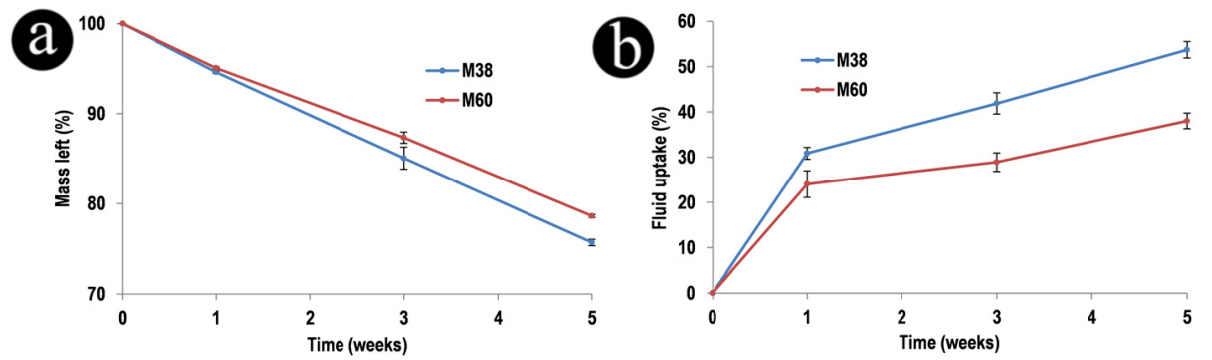

Figure 12. (a) Mass loss and (b) fluid uptake of the two composites when soaked for 12 weeks. Significant differences were observed between the two materials at every time point (except mass loss at week 1).

\section{a}

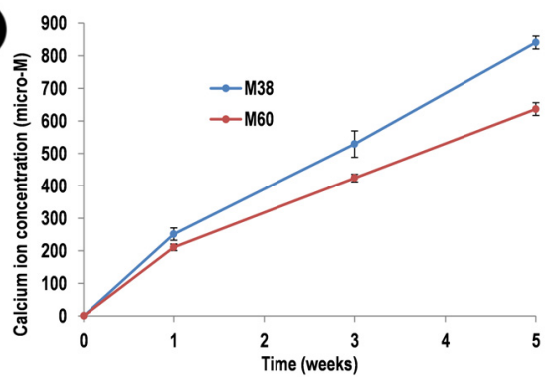

(b)

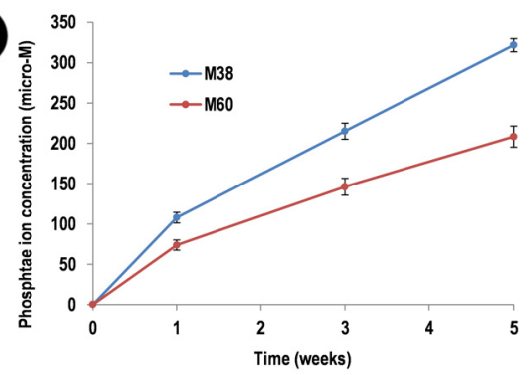

Figure 13. (a) Calcium and (b) phosphate ion (measured) cumulative concentration in PBS where the two composites were soaked for 12 weeks. Significant differences were observed between the two materials at every time point.

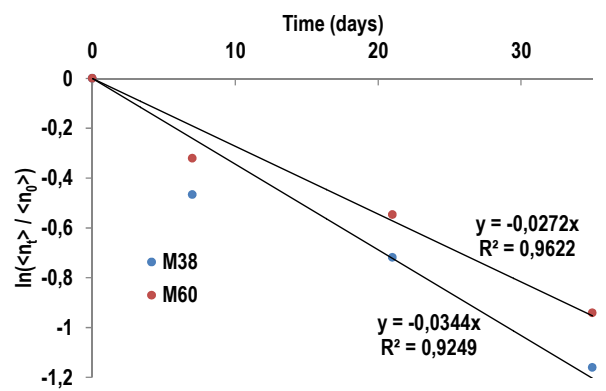

Figure 14. Autocatalysed degradation model at $50^{\circ} \mathrm{C}$ for the polymer phase in the two composites. M38 has a quicker hydrolysis rate than M60 (i.e. the absolute constants were $\mathrm{k}_{\mathrm{M} 38}=0.0344$ day $^{-1}, \mathrm{k}_{\mathrm{M} 60}=0.0272$ day $^{-1}$ ).

\section{7a.3.4. Dynamic mechanical analysis}

The recorded storage modulus was significantly higher in M60 than M38 (i.e. with high molecular weight copolymer) while the loss tangent was lower (Figure 15). The modulus and loss tangent did not significantly change with the frequency for both materials. These results confirm the role molecular weight has on the dynamic mechanical characteristics of the composites. 

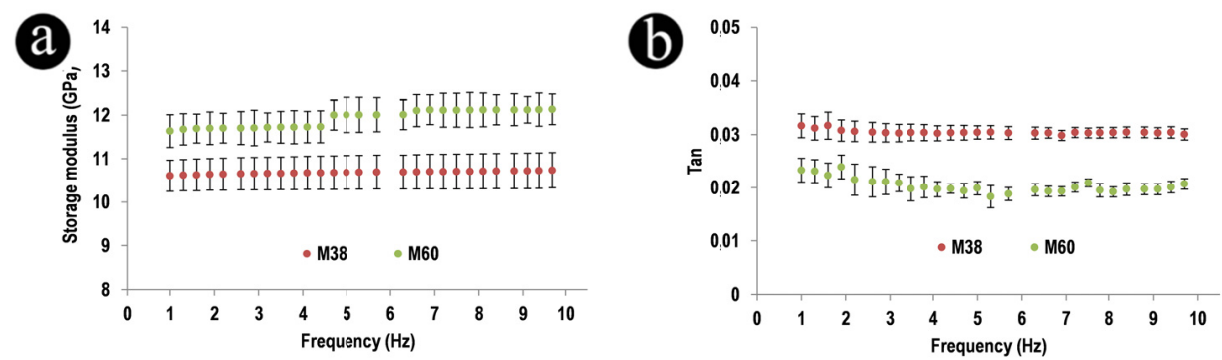

Figure 15. Recorded (a) storage modulus and (b) loss tangent of M38 and M60. The measurements were performed on dry samples in dry air at $37^{\circ} \mathrm{C}$.

\section{7a.3.5. Animal study}

Five samples of each composite were intramuscularly implanted in five sheep, and after six months all samples were retrieved. The explants were surrounded by thin layers of connective tissue and muscle. Histological observations demonstrated that heterotopic bone formation was triggered in all M38 implants but in none of M60 samples (Table 8, Figure 16). Mature bone formed tightly to the mineralised surfaces of ML granules, while non-mineralised bone matrix, with active osteoblast-like cells, was observed on the outer surface of the mature bone indicating ongoing bone formation (Figure 17). Amongst the granules, bone marrow has been observed indicating the bone remodelling may have occurred over six months.

Table 8. Bone incidence, histomorphometry and fluorescent results after 6-month implantation in sheep.

\begin{tabular}{lll}
\hline & $\mathrm{M} 38$ & $\mathrm{M} 60$ \\
\hline Bone incidence & $5 / 5$ & $0 / 5$ \\
\hline Bone in available space [\%] & $7.8 \pm 2.3$ & $0 \pm 0$ \\
\hline
\end{tabular}
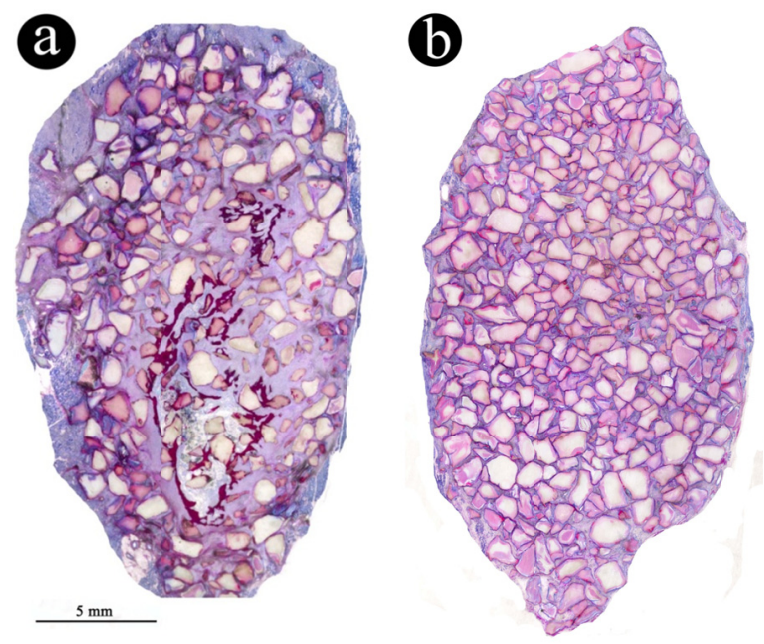

Figure 16. Low magnification scans of explants. (a) Heterotopic bone formed in all M38 implants. (b) None of the M60 composites induced bone formation. Bone is indicated by the dark pink areas. 


\section{7a.4. Discussion}

The results in this Addendum confirm the importance of the choice of molecular weight when designing instructive composites of polymer and calcium phosphates. We have shown that the copolymer molecular weight influenced the bone forming ability of its composites with calcium phosphate apatite. Only the lower molecular weight polymer containing implants (i.e. M38) induced heterotopic bone formation. After accelerated 5week degradation in PBS to simulate a long-term degradation, we observed that M38 composite absorbed larger amount of fluids and had a degrading trend faster than M60 because, most likely, hydrolysis was favoured. ${ }^{[349,350]}$ At the same time, we possibly due to the degradation, M38 may have exposed more apatite particles on its surfaces, which led to the release of larger amounts of calcium and phosphate ions. Such ions are believed to be signalling molecules for bone cells ${ }^{[226-228,252]}$ and may also enhance surface mineralisation. ${ }^{[227,228,324]}$ Together the possible enhanced surface roughness caused by the exposure of apatite, they may have contributed in triggering osteoinduction in M38. Further, with the molecular weight it is possible to modulate the mechanical properties together with osteoinduction.
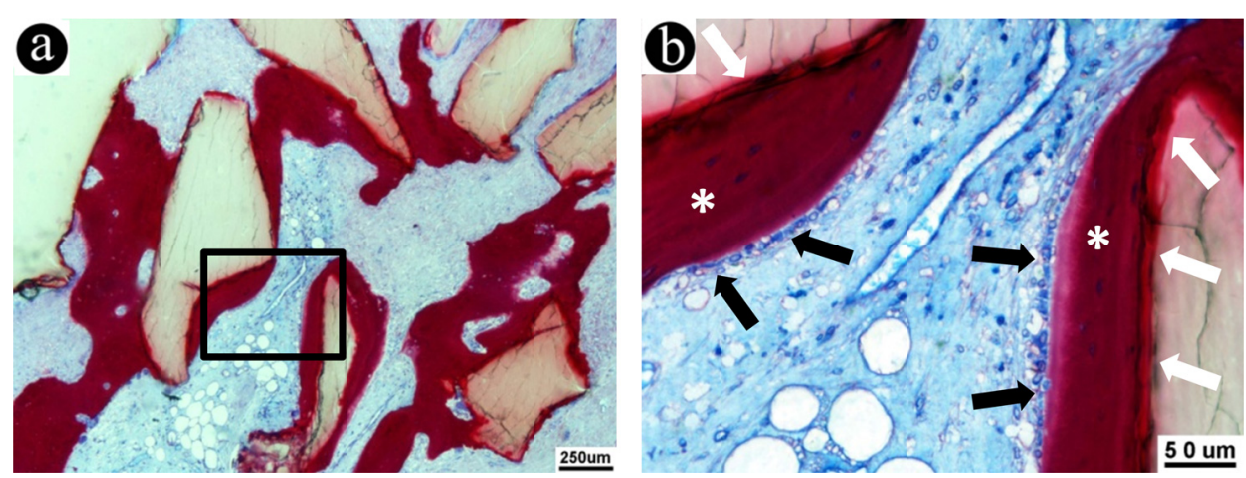

Figure 17. Histology images (non-decalcified, $1 \%$ methylene blue and $0.3 \%$ basic fuchsin staining) of M38 explant harvested from the muscle of sheep after six months. Image (b) is the magnification of the box in image (a). Heterotopic bone (white stars) formation was induced and an active, but not yet mineralized, bone formation zone is visible, where a seam of osteoblasts is onto its outer surface (black arrows). Surface mineralisation occurred (white arrows) and bone tightly formed onto these mineralized layers. Bone marrow and some blood vessels were observed as well.

\section{7a.5. Conclusion}

The results in this Addendum confirm the importance of the choice of molecular weight when designing instructive composites of polymer and calcium phosphates as proposed in Chapter 7. We have shown that the molecular weight of the polymer phase in instructive composites influences, besides the mechanical properties and the degradation trend, also its heterotopic bone forming ability. 


\section{CHAPTER 8}

General discussion 



\subsection{General discussion}

\subsubsection{Tissue engineering: issues and benefits}

Two science fields born during the last century with a common challenging dream are regenerative medicine and tissue engineering, which both aim to artificially replace and/or regenerate lost or damaged tissues. They have different approaches to the clinical problems: regenerative medicine mainly focuses on (stem) cell therapy methodologies, whereas tissue engineering combines biomaterial science concepts with cell biology and medicine. Recently, they have shown huge potential to recover nearly-dead tissues that lost their functions after debilitating conditions such as myocardial infarction, spinal injury, skin burns, osteoporosis and liver cirrhosis.

In general, tissue engineering aims to design systems where a biomaterial scaffold provides environmental cues to cells to promote tissue formation either in vitro or directly in vivo. ${ }^{[399]}$ A milestone is the year 1997, when the first tissue engineered product was approved for clinical use in skin replacement and was rendered available on the medical market. ${ }^{[399]}$ Since then, fast growth of discoveries in cell biology and materials science allowed the development of many new products available for preclinical and clinical therapies for many tissues such as bladder and trachea.[400, 401]

Along with human benefits, tissue engineering could also bring financial benefits to the holders of clinically successful tissue engineering concepts. However, the path to clinical and commercial success is fraught with obstacles. In fact, providing effective products is not in itself enough to guarantee commercial success. Issues such as costs, scaling-up, shelf life, quality control, regulatory hurdles and distribution of tissue engineering products rendered difficult to build appropriate business strategies and led to the cessation of many financial investments on the research and development. ${ }^{[399,}{ }^{402,403]} \mathrm{A}$ combination of clinical performance, simplicity in use, costeffectiveness and marketing is necessary for the success of a tissue engineering product. Reaching such equilibrium in developing tissue engineered constructs is challenging because, on one side, scaffold materials must provide complex information, through their physicochemical properties, to direct cells towards tissue regeneration. On the other side financial and marketing considerations require low system complexity. For this reason, tissue engineered products should be developed through as simplest as possible steps, each with clear goals. An emerging strategy is not attempting to recreate the complexity of tissues in vitro, but to focus on the development of synthetic materials that have 'intrinsic' features able to actively interact with (stem) cells in vivo and to instruct them determining their fate. Therefore, newly developed biomaterials should be carefully designed to have specific local characteristics (e.g. surface stiffness, chemistry and topography) that 
can induce various and controlled cellular behaviors ultimately leading to new tissue synthesis. ${ }^{[103,152-154]}$

\subsubsection{Instructive biomaterials in bone tissue engineering}

In bone tissue regeneration, a subgroup of instructive biomaterials has the potential to favor undifferentiated stem cells to differentiate into bone phenotype without addition of (osteogenic) factors or cells (i.e. biomaterial-directed osteoinduction phenomenon) [. ${ }^{[86]}$ It has been suggested that the micro-structured surface of certain calcium phosphate ceramics may be a key factor inducing and supporting heterotopic bone growth in large animals (e.g. dog and sheep), ${ }^{86,}$ 228, 236, 237] and such osteoinductive ceramics demonstrated to be effective alternatives to autologous bone grafts in critical-sized bone defects. ${ }^{[86,238]}$ Besides the clear biological benefits such ceramics bring, they have two main drawbacks: their handling characteristics and their brittleness. In this thesis we evaluated the material factors to be considered when designing instructive and improved calcium phosphate-based materials by means of composites. According to the European Composites Industry Association (EuClA), ${ }^{[404]}$ composite materials are the combination of two or more materials to reinforce their properties making them mechanically, chemically, physically or biologically better together than they are apart. Thus, to improve the handling or mechanical performances of osteoinductive calcium phosphates we added a polymer component to obtain composite materials. The calcium phosphate phase would contribute to the biological (i.e. osteoinductive) properties of the composite whereas the polymer phase would have roles in the handling and mechanical properties. However, adding a polymer may have effects or even take actively part in the material-directed osteoinductive phenomenon. The challenge in this thesis was to develop composite biomaterials that are, at the same time, degradable to leave room to the growing tissue, mechanically suitable for the required clinical application in load-bearing sites, have good handling properties and still be osteoinductive. In particular, we evaluated the design factors involved when designing such instructive composite biomaterials for bone tissue regeneration.

\subsubsection{Dissolution rate of (hydro)gels and osteoinduction}

Most osteoinductive calcium phosphate ceramics are manufactured in block or particular forms, which have poor handling properties. Adding a polymer (hydro)gel to ceramic particulate has been proposed as a way to prepare putties and/or injectable pastes with better handling properties. Initial (stem) cell adhesion on the surface of osteoinductive ceramics appears to be the first step to trigger osteoinduction phenomenon. ${ }^{[86]}$ Therefore, we hypothesized that covering the micro-structured 
ceramic surface with a slowly dissolvable polymer (hydro)gel would inhibit or delay cell adhesion and thus osteoinduction. To evaluate this, we used polymer binders with different dissolution rates and studied their effect on bone induction when combined with micro-structured ceramics and after ectopic implantation. Our results indicated that the availability of the ceramic micro-structured surface to the surrounding tissue in early post-implantation time is crucial. Moreover, free space between granules is likely necessary for vasculature formation and soft tissue infiltration, which may be obstructed with slower degrading (hydro)gels reducing, or even nullifying, the chances of stem cell migration into the implant. It was concluded in Chapter 2 that designing instructive putties (or injectable pastes) implies careful choice of the binder, whose chemistry and dissolution rate are crucial factors for its in vivo performance.

\subsubsection{Manufacturing nano-composites: considerations}

As mentioned earlier, the intrinsic brittleness of (commercially available) ceramic materials restricts their use as fillers to mechanically non-loaded sites. Thus scientists strive to design biologically active composite materials that may bear mechanical loads. At the same time, to favor bone growth and full replacement of the implant with new tissue over time, controllable degradation rate is a crucial property as well. Adding (micro- or nano-) (hydroxy)apatite particulate or fibres into polylactide led to porous materials with improved mechanical properties. ${ }^{[239,240] \text { In }}$ particular, composites containing more than $40 \%$ wt. hydroxyapatite resulted also osteoconductive, ${ }^{[241]}$ with enhanced protein adsorption and osteoblast adhesion in vitro. ${ }^{[241-243]}$ In some cases, such porous composites fabricated with solvent-methods were reported to be osteoinductive as well.[235] However, to support (physiological) cyclic stresses, composites may need dense bulk with homogeneous distribution of calcium phosphate particulate in the polymer matrix, which relies on the manufacturing method. We observed that, despite the occurrence of thermal and frictional degradation of the polymer phase, extrusion could be used to make highly homogeneous composites with mechanical characteristics similar to those of dry bone (Chapter 4). Consistently with literature results, ${ }^{[336]}$ we observed that extrusion decreased the molecular weight of the polymer. In particular, this effect was dependent on the starting molecular weight of the used polymers and on the filler content (Chapters 4,5). On the contrary, a solvent-based method did not have degrading effects on the polymer but led to inhomogeneous porous materials and issues such as incomplete solvent evaporation (Chapter 3). This fact has consequences on the mechanical and degradation features of the composite. It was therefore concluded that the manufacturing method is a crucial factor to be 
considered during the design of a composite material regarding mechanical property and degradation.

\subsubsection{Effects of filler content in nano-composites}

By controlling the amount of apatite in composites, the mechanical properties and degradation trend can be tuned (Chapter 4). Besides this, it also determines their osteoinductive property as shown in Chapter 3. In fact, similarly to results in literature, ${ }^{[239,240]}$ the presence of nano-sized filler stiffened the composites. Since the viscoelastic characteristics are mainly controlled by the polymer phase, the apatite content had an indirect effect on them because, during extrusion process, it degraded the polymer molecular weight. The composite with the highest filler content was therefore stiffest but also had the largest damping characteristics (Chapter 4). The apatite content influenced the hydrophilicity of the composites as well, and this had direct consequences on the mechanical and degradation characteristics. As expected, we observed higher fluid uptake by the composites with higher filler content. These composites also had the largest decrease in stiffness and largest increase in damping properties (Chapter 4). Similarly to what is reported in literature, higher fluid uptake led to quicker apatite dissolution ${ }^{[249,314]}$ and polymer hydrolysis ${ }^{[349}$, 387] with consequent larger mass loss and ion release. However, increasing amount of apatite accelerated the degradation of the whole composite, which clashes with most of results in literature, [235, 239, 240,242, 243, 409] because in this situation we used an extrusion method, instead of solvent-based ones, to prepare the materials. Extrusion led to decreases in polymer intrinsic viscosity with the increase of apatite content, with direct impact on the composite degradation since the differences of the final intrinsic viscosity amongst the three materials were significantly large (Chapter 4). Besides stiffening and rendering the composites more degradable, the filler content also had an effect on the biological properties. For example, we observed that surface mineralization was enhanced when larger amounts of filler were available at the surface of the composites (Chapters 3 and 7). Furthermore, the exposure of apatite particles on the surface rendered the composite surfaces rougher. Similarly to others, ${ }^{[363]}$ we observed that composites with rougher surfaces induced significantly more osteogenic differentiation of human bone marrow stromal stem cells (Chapter 7). These events may have contributed to the triggering of heterotopic bone formation in composites with filler content higher than $40 \%$ wt. (Chapter 3). Thus, the filler content is another critical design factor to be carefully considered as it controls, either directly or indirectly, many material features including hydrophilicity, elasticity and viscoelasticity, degradation and surface roughness that will affect the performance of composites in vitro and in vivo. 


\subsubsection{Surface roughness}

Surface roughness is another material parameter that can influence on the biological processes occurring at the interface between material and surrounding tissues. ${ }^{[195,363]}$ We observed that the roughest composite material adsorbed most proteins, surface mineralised and was able to trigger osteogenic differentiation of human bone marrow stromal stem cells. In view of these properties, we expected that this material would initiate bone formation. But no osteoinduction was observed and it could be most because of the very slow degradation of the composites due to the semi-crystalline polymer used (i.e. copolymer containing $96 \% \mathrm{~mol}$. L-lactide). Surface roughness is a parameter that should be kept in mind when designing biomaterials. It affects the final material properties and can have implications on its biological performances, both in vitro and in vivo. However, we should carefully consider the fact that in vitro systems used to study the biomaterials may lead us far from its real in vivo performances. It indicates that extrapolating in vitro biological results (e.g. cell culture or protein adsorption) into in vivo performances is still nowadays a complex issue.

\subsubsection{Role of polymer phase features in nano-composites}

The effect of two intrinsic characteristics of the polymer phase in the composites, i.e. the molecular weight and the monomer chemistry, was evaluated as well. Consistently with polymer science literature, ${ }^{[347,348]}$ we observed that low molecular weight polymer phase, or the presence of D,L-lactide monomer, allowed larger fluid uptake in their composites (Chapters 6 and 7), which in turn indirectly enhanced the biological properties. In particular, composites with low molecular weight polymer, or containing D,L-lactide monomer, absorbed more fluids and activated a cascade of surface events. Serum proteins were taken up and the formation of thicker nanostructured mineralised surfaces may have allowed for even higher amounts of protein adsorption. Cell colonisation on the mineralised surface may have been enhanced by adsorbed protein motifs, which could have aided in heterotopic bone formation. A larger fluid uptake also caused a higher degradation rate, with consequent release of ions and increase of available space for bone ingrowth. The molecular weight and monomer did not only have effect on the biological and degradation properties, but also on the mechanical properties. As expected, an increase in stiffness and decreased damping properties were seen for those composites with polymers having high molecular weight or low D, L-lactide content. 
8.1.8. Other possible factors: monomer content and polymer (semi)-crystallinity It should be mentioned that other intrinsic characteristics of the polymer should not be excluded from the set of possible factors influencing the properties of the composites. For instance, it has been reported that the monomer content after extrusion varies, presumably increases, ${ }^{[336,411]}$ facilitating the fluid uptake and thus the polymer hydrolysis. This fact may not only affect the mechanical properties, particularly in moistened conditions (Chapter 4), but also the instructive potential of the composites. Another intrinsic feature is the polymer (semi)-crystallinity, which is dependent on the processing steps, e.g. the cooling, ${ }^{[387]}$ (Chapter 4). Crystallinity has been shown to influence the mechanical performance, degradation and cell response to polymer surfaces. $[387,412,413]$ Thus, it is advisable to consider these factors as well in future studies on composites and their performances.

\subsubsection{Importance of fluid uptake in osteoinductive biomaterials}

We have evaluated two classes of biomaterials, i.e. calcium phosphate ceramics and composites, to investigate whether a common link between material properties and osteoinduction exists. Based on our results, hydrophilicity improves the contact between fluids and biomaterial by virtue of larger fluid uptake. As fluids carry various molecules and ions, such improved contact would enhance biomolecule adsorption and surface mineralization thanks to the higher probability of contact between the biomaterial surface and such molecules. It is also proposed that it may enhance the early cell response upon implantation, triggering macrophages to secrete cytokines that later could induce bone induction. Further, absorbed fluids would accelerate the polymer hydrolysis and calcium phosphate dissolution enhancing the degradation of biomaterials and facilitating the release of calcium and phosphate ions. Degradation of biomaterials may also generate changes at the surface, for example by exposing more calcium phosphates or generating nano- or micro-porosity. The combination of such phenomena triggered by fluid uptake contributed to the heterotopic bone formation. However, we also observed that it was possible to apply this hypothesis separately per each class of biomaterial, but it was not valid under a more general 'biomaterial' view (Chapter 6).

\subsubsection{Closing remarks}

A balance between biomaterial design complexity and feasibility (from research, industrial and financial points of view) is necessary. We found that designing an instructive biomaterial with proper dynamic mechanical properties, degradation rate and osteoinductive potential is challenging because various factors are involved and influence each other. In fact, we wanted to make a strong composite material able 
to control cell fate in vivo triggering their osteogenic differentiation into bonesynthesizing cells without adding osteogenic (growth) factors to the material itself. Then, when trying to improve mechanical properties, we increased the molecular weight of the polymer phase and the biological characteristics of the composite worsened and vice versa. Thus, we had to face with the challenge that either excessively simplifying the system, or excessively complicating it, may be detrimental for the performance efficacy of the biomaterial. This concept can be extended to a more general view: a biomaterial approach should focus on a few simple mechanisms occurring in nature that effectively influence and control cell fate and try to reproduce them in a material. In particular, in view of a simple and effective approach we should focus on simple and controllable 'intrinsic' properties of biomaterials that are then able to interact with the biological environment by means of protein adsorption, surface mineralization and release of certain ions that will influence on cell behaviour. For example, the surface properties or the chemistry have been reported to play important roles such biological phenomena and in instructing cells.

However, as mentioned earlier, we wanted to design a biomaterial that, upon implantation, supports, or replaces, the tissue function by means of simple 'physical' mechanisms (in view of simplifying the system). The material, once implanted, may degrade leaving room for the growing new tissue. In this scenario, the choice of material factors is crucial to trigger biological phenomena involving tissue cells and intrinsic properties of materials such as surface features or mechanical performance.

For instance, successful attempts to design an artificial vocal cord were accomplished, ${ }^{[405]}$ where the main issue was mimicking the viscoelastic properties of the cord since it varies its dynamic viscosity with the frequency of stimulus (i.e. the vibrational stress given by the air flush during the talk) for a proper phonation. However, this material still has to demonstrate its effectiveness in driving cell fate and supporting new cord tissue formation. This example demonstrates how challenging is to design a biomaterial that have controllable 'multiple' characteristics.

The mechanisms of tissue formation and healing are still unknown, although new discoveries in cell biology and medicine are contributing to the development of new instructive materials that fully or partially mimic nature's structures and regenerative mechanisms. These new insights highlight the issues of (1) what is the minimum level of material complexity required for the regeneration of specific tissues, and (2) how to balance the feasibility of new biomaterial design with the regulatory implications, costs of the final device and its ease of use by surgeons, design time and, to a less extent, available funding.

As already seen, interest is growing in the exciting possibility of using simple material properties that physically or chemically influence cell behavior. Current worldwide 
research is actively pursuing simple but effective solutions to tissue engineering problems, such that the ideal of structurally simple, yet functionally complex, biomaterials, for the near future. For example, osteoinductive micro-structured calcium phosphate ceramics have already widely shown their potential in instructing cells by means of the simple control of their surface/chemistry and are currently commercially available (Attrax ${ }^{\top \mathrm{M}}$, Nuvasive Inc., San Diego, USA). At the same time, we have shown in this thesis that producing degradable composite materials able to instruct cells in vivo, with improved handling and mechanical properties is possible. Such composites can be obtained by designing them with few proper 'intrinsic' characteristics, such as choosing the polymer phase molecular weight and monomer, the inorganic filler content and chemistry. Besides this, further improving osteoinductive calcium phosphate ceramics and composites may be pursued by, for instance, adding ions to their chemical structure. Unpublished results from members of our group have observed that adding certain ions (e.g. zinc, strontium or fluorine) to calcium phosphate ceramics and composites can have beneficial effects on their osteoinductive potential. In closing, exciting scenarios in developing biomaterials that can actively interact with biological elements loom up on the horizon. 


\section{REFERENCES}



[1] Waggoner B. Eukaryotes and multicells: origin. In: Encyclopedia of Life Sciences 2001, MacMillan Publishers Ltd., Nature Publishing Group / www.els.net, p. 1.

[2] Alberts K, Bray D, Lewis J, Raff M, Roberts K, Watson JD. The evolution of the cell. In: Molecular Biology of the Cell (3rded), 1994, New York: Garland Science, p. 3.

[3] Schopf JW. Microfossils of the early Archean Apex Chert: new evidence of the antiquity of life. Science 1993, 260, 640.

[4] Voet D, Voet JG, Pratt CW. Life: the Origin of Life. In: Harris D (ed), Fundamentals of Biochemistry. Upgrade Edition, 2002, NY: John Wiley and Sons, p. 3.

[5] Oparin Al. The Origin of Life.1924, Moscow: Moscow Worker Publisher. English translation: Oparin Al, The Origin and Development of Life (NASA TTF-488) 1968, Washington: D.C.L. GPO.

[6] Miller SL. A production of amino acids under possible primitive Earth conditions. Science 1953, 117, 528.

[7] Trevors JT. Early assembly of cellular life. Prog. Biophys. Mol. Biol. 2003, 81, 201.

[8] Gelse K, Pöschl E, Aigner T. Collagens - structure, function and biosynthesis. Adv. Drug Del. Rev. 2003, 55, 1531.

[9] Myllyharju J, Kivirikko KI. Collagens, modifying enzymes and their mutations in humans, flies and worms. Trends Genet. 2004, 20, 33.

[10] Ott HC, Matthiesen TS, Goh SK, Black LD, Kren SM, Netoff TI, Taylor DA. Perfusion-decellularized matrix: using nature's platform to engineer a bioartificial heart. Nat. Med. 2008, 14, 213.

[11] de Belle L, Alix AJP. The structures of elastins and their function. Biochimie 1999, $81,981$.

[12] Gandhi NS, Mancera RL. The structure of glycosaminoglycans and their interactions with proteins. Chem. Biol. Drug Des. 2008, 72, 455.

[13] Toole BP. Hyaluronan: from extracellular glue to pericellular cue. Nat. Rev. Cancer 2004, 4, 528.

[14] Morgan MR, Humphries MJ, Bass MD. Synergistic control of cell adhesion by integrins and syndecans. Nat. Rev. Mol. Cell. Biol. 2007, 8, 957.

[15] Heldin CH, Rubin K, Pietras K, Östman A. High interstitial fluid pressure - an obstacle in cancer therapy. Nat. Rev. Canc. 2004, 4, 806.

[16] Megill WM, Gosline, JM, Blake RW. The modulus of elasticity of fibrillincontaining elastic fibres in the mesoglea of the hydromedusa Polyorchis penicillatus. J. Exp. Biol. 2005, 208, 3819.

[17] Benović A. Diurnal vertical migration of Solmissus albescens (Hydromedusae) in the southern Adriatic. Mar. Biol. 1973, 18, 298.

[18] Mackay WC. Sulphate regulation in jellyfish. Comp. Biochem. Physiol. 1969, 30, 481. 
[19] Denton EJ, Shaw TI. The buoyancy of gelatinous marine animals. J. Physiol. 1962, 161, 14.

[20] Kumar V, Abbas AK, Fausto N, Aster J. In: Robbins and Cotran Pathologic Basis of Disease, $8^{\text {th }}$ Edition, 2010, Elsevier.

[21] Rho JY, Kuhn-Spearing L, Zioupos P. Mechanical properties and the hierarchical structure of bone. Med. Eng. Phys. 1998, 20, 92.

[22] Fratzl P, Gupta HS, Paschalis EP, Roschger P. Structure and mechanical quality of the collagen-mineral nano-composite in bone. J. Mater. Chem. 2004, 14, 2115.

[23] Xin R, Leng $Y$, Wang N. HRTEM study of the mineral phase in human cortical bone. Adv. Eng. Mater. 2010, 12, B552.

[24] Hong SI, Hong SK, Kohn DH. Nanostructural analysis of trabecular bone. J. Mater. Sci: Mater. Med. 2009, 20, 1419.

[25] Yamaguchi M. Role of zinc in bone formation and bone resorption. J. Trace El. Exp. Med. 1998, 11, 119.

[26] Roveri N, Battistella E, Bianchi CL, Foltran I, Foresti E, lafisco M, Lelli M, Naldoni A, Palazzo B, Rimondini L. Surface enamel remineralization: biomimetic apatite nanocrystals and fluoride ions different effects. J. Nanomater. 2009, article ID 746383. [27] Landis W. The strength of a calcified tissue depends in part on the molecular structure and organization of its constituent mineral crystals in their organic matrix. Bone 1995, 16, 533.

[28] Shorr E, Carter A. The usefulness of strontium as an adjuvant to calcium in the remineralization of the skeleton in man. Bull. Hosp. Joint Dis. Orthoped. Ist., 1952, 13, 59.

[29] Bigi A, Foresti E, Gregorini R, Ripamonti A. The role of magnesium on the structure of biological apatites. Calc. Tiss. Int. 1992, 50, 439.

[30] Rodan GA. Commentary bone homeostasis. PNAS USA 1998, 95, 13361.

[31] Hill P. Bone remodeling. J. Orth. 1998, 25, 101.

[32] Bonewald LF, Johnson ML. Osteocytes, mechanosensing and Wnt signaling. Bone 2008, 42, 606.

[33] Turner CH, Warden SJ, Bellido T, Plotkin LI, Kumar N, Jasiuk I, Danzig J, Robling AG. Mechanobiology of the skeleton. Sci. Signal. 2009, 2, pt3.

[34] Bonewald LF, Johnson ML. Osteocytes, mechanosensing and Wnt signaling. Bone 2008, 42, 606.

[35] Thompson WR, Rubin CT, Rubin J. Mechanical regulation of signaling pathways in bone. Gene 2012, 503, 179.

[36] Moriishi T, Fukuyama R, Ito M, Miyazaki T, Maeno T, Kawai Y, Komori H, Komori $T$. Osteocyte network: a negative regulatory system for bone mass augmented by the 
induction of rank in osteoblasts and sost in osteocytes at unloading. PLoS One 2012, 7, e40143.

[37] Kamioka H, Kameo Y, Imai Y, Bakker AD, Bacabac RG, Yamada N, Takaora A, Yamashiro T, Adachi T, Klein-Nulend J. Microscale fluid flow analysis in a human osteocyte canaliculus using a realistic high-resolution image-based three-dimensional model. Integr. Biol. (Camb) 2012, PMID: 22858651.

[38] Taylor D, Hazenberg JG, Lee TC. Living with cracks: damage and repair in human bone. Nat. Mater. 2007, 6, 263.

[39] Wu DC, Boyd AS, Wood KJ. Embryonic stem cell transplantation: potential applicability in cell replacement therapy and regenerative medicine. Front. Biosci. 2007, 12, 4525.

[40] Shevde N. Stem cells: flexible friends. Nature 2012, 483, S22.

[41] Gadue P, Huber TL, Nostro MC, Kattman S, Keller GM. Germ layer induction from embryonic stem cells. Exp. Hematol. 2005, 33, 955.

[42] Slack JM. Stem cells in epithelial tissues. Science 2000, 287, 1431.

[43] Conover JC, Notti RQ. The neural stem cell niche. Cell Tissue Res. 2008, 331, 211.

[44] Moore KA, Lemischka IR. Stem cells and their niches. Science 2006, 311, 1880.

[45] Xie T, Li L. Stem cells and their niche: an inseparable relationship. Development 2007, 134, 2001.

[46] Katayama Y, Battista M, Kao WM, Hidalgo A, Peired AJ, Thomas SA, Frenette PS. Signals from the sympathetic nervous system regulate hematopoietic stem cell egress from bone marrow. Cell 2006, 124, 407.

[47] da Silva ML, Chagastelles PC, Nardi NB. Mesenchymal stem cells reside in virtually all post-natal organs and tissues. J. Cell Sci. 2006, 119, 2204.

[48] Crisan M. A perivascular origin for mesenchymal stem cells in multiple human organs. Cell Stem Cell 2008, 3, 301.

[49] Reubinoff BE, Itsykson P, Turetsky T, Pera MF, Reinhartz E, Itzik A, Ben-Hur T. Neural progenitors from human embryonic stem cells. Nat. Biotech. 2001, 19, 1134.

[50] Seaberg RM, van der Kooy D. Stem and progenitor cells: the premature desertion of rigorous definitions. Trends Neurosci. 2003, 26, 125.

[51] Jahagirdar NB, Verfaillie CM. Multipotent adult progenitor cell and stem cell plasticity. Stem Cell Rev. 2005, 1, 53.

[52] Wagers AJ, Weissman IL. Plasticity of adult stem cells. Cell 2004, 116, 639.

[53] Goss RJ. Regeneration versus repair, In: Cohen IK, Diegelman RF, Lindblad WJ (eds), Wound Healing: Biochemical and Clinical Aspects 1992, Philadelphia: WB Saunders, p. 20. 
[54] Brockes JP. Amphibian limb regeneration. Rebuilding a complex structure. Science 1997, 276, 81.

[55] Fujisawa T. Hydra regeneration and epitheliopeptides. Dev. Dyn. 2003, 226, 182.

[56] Stappenbeck TS, Miyoshi $\mathrm{H}$. The role of stromal stem cells in tissue regeneration and wound repair. Science 2009, 324, 1666.

[57] Shibata N, Rouhana L, Agata K. Cellular and molecular dissection of pluripotent adult somatic stem cells in planarians. Dev. Growth Differ. 2010, 52, 27.

[58] Umesono Y, Tasaki J, Nishimura K, Inoue T, Agata K. Regeneration in an evolutionary primitive brain - the planarian Dugesia japonica model. Eur. J. Neurosci. 2011, 34, 863.

[59] Lindahl A. Tissue homeostasis, In: van Blitterswijk CA (ed), Tissue Engineering 2008, London: Elsevier Academic Press, p. 73.

[60] Oh $\mathrm{H}$, Humphries RK. Concise review: multidimensional regulation of the hematopoietic stem cell state. Stem Cells 2012, 30, 82.

[61] Chen JS, Wong VW and Gurtner GC. Therapeutic potential of bone marrowderived mesenchymal stem cells for cutaneous wound healing. Front. Immun. 2012, 3, 192.

[62] Kachgal S, Carrion B, Janson IA, Putnam AJ. Bone marrow stromal cells stimulate an angiogenic program that requires endothelial MT1-MMP. J. Cell. Phys. 2012, 227, 3546.

[63] Bryder D, Rossi DJ, Weissman IL. Hematopoietic stem cells: the paradigmatic tissue-specific stem cell. Am. J. Pathol. 2006, 169, 338.

[64] Bigas A, Espinosa L. Hematopoietic stem cells: to be or Notch to be. Blood 2012, $119,3226$.

[65] Fox JM, Chamberlain G, Ashton BA, Middleton J. Recent advances into the understanding of mesenchymal stem cell trafficking. Br. J. Haematol. 2007, 137, 491.

[66] Caplan Al. Adult mesenchymal stem cells for tissue engineering versus regenerative medicine. J. Cell. Physiol. 2007, 213, 341.

[67] Caplan Al. Why are MSCs therapeutic? New data: new insight. J. Pathol. 2009, 217, 318.

[68] Bonfield TL. Adult mesenchymal stem cells: an innovative therapeutic for lung diseases. Discov. Med. 2010, 47.

[69] Fausto N, Campbell JS. The role of hepatocytes and oval cells in liver regeneration and repopulation. Mech. Dev. 2003, 120, 117.

[70] Fausto N. Liver regeneration and repair: hepatocytes, progenitor cells and stem cells. Hepatology 2004, 39, 1477.

[71] Taupin P. Adult neural stem cells, neurogenic niches and cellular therapy. Stem Cell Rev. 2006, 2, 213. 
[72] Kokovay E, Wang Y, Kusek G, Wurster R, Lederman P, Lowry N, Shen q, Temple S. VCAM1 is essential to maintain the structure of the SVZ niche and acts as an environmental sensor to regulate SVZ lineage progression. Cell Stem Cell 2012, $11,220$.

[73] Okano H, Sakaguchi M, Ohki K, Suzuki N, Sawamoto K. Regeneration of the central nervous system using endogenous repair mechanisms. J. Neurochem. 2007, 102, 1459.

[74] Fuchs E. Skin stem cells: rising to the surface. J. Cell Biol. 2008, 180, 273.

[75] Ohyama M, Terunuma A, Tock CL, Radonovich MF, Pise-Masison CA, Hopping SB, Brady JN, Udey MC, Vogel JC. Characterization and isolation of stem cellenriched human hair follicle bulge cells. J. Clin. Invest. 2006, 116, 249.

[76] Yen TH, Wright NA. The gastrointestinal tract stem cell niche. Stem Cell Rev. 2006, 2, 203.

[77] Chargé SBP, Rudnicki MA. Cellular and molecular regulation of muscle regeneration. Physiol. Rev. 2004, 84, 209.

[78] Hsieh PCH, Segers VFM, Davis ME, MacGillivray C, Gannon J, Molkentin JD, Robbins J, Lee RT. Evidence from a genetic fate-mapping study that stem cells refresh adult mammalian cardiomyocytes after injury. Nat. Med. 2007, 13, 970.

[79] Daniels JT, Harris AR, Mason C. Corneal epithelial stem cells in health and disease. Stem Cell Rev. 2006, 2, 247.

[80] Carlson BM. Some principles of regeneration in mammalian systems. Anat. Records B: New Anat. 2005, 287B, 4.

[81] Michalopoulos GK, de Frances MC. Liver regeneration. Science 1997, 276, 60.

[82] Kawasaki S, Makuuchi M, Ishizone S, Matsunami H, Terada M, Kawarazaki $\mathrm{H}$. Liver regeneration in recipients and donors after transplantation. Lancet 1992, 339, 580.

[83] Starzl TE, Fung J, Tzakis A, Todo S, Demetris AJ, Marino IR, Doyle H, Zeevi A, Warty V, Kusne S, Rudert WA, Trucco M, Michaels M. Baboon-to-human liver transplantation. Lancet 1993,341, 65.

[84] Berry MF, Engler AJ, Woo YJ, Pirolli TJ, Bish LT, Jayasankar V, Morine KJ, Gardner TJ, Discher DE, Sweeney HL. Mesenchymal stem cell injection after myocardial infarction improves myocardial compliance. Am. J. Physiol. Heart. Circ. Physiol. 2006, 290, H2196.

[85] Park J, Ries J, Gelse K, Kloss F, von der Mark K, Wiltfang J, Neukam FW, Schneider $\mathrm{H}$. Bone regeneration in critical size defects by cell-mediated BMP-2 gene transfer: a comparison of adenoviral vectors and liposomes Gene Therapy 2003, 10, 1089. 
[86] Yuan H, Fernandes H, Habibovic P, de Boer J, Barradas AMC, de Ruiter A, Walsh WR, van Blitterswijk CA, de Bruijn JD. Osteoinductive ceramics as a synthetic alternative to autologous bone grafting. PNAS 2010, 107, 13614.

[87] McKim LH. Regeneration of the distal phalanx. Can. Med. Assoc. J. 1932, 26, 549.

[88] Vidal P, Dickinson MG. Regeneration of the distal phalanx. A case report. J. Hand Surg. Br. 1993, 18, 230.

[89] Kyzas PA, Stefanou D, Batistatou A, Agnantis NJ. Hypoxia-induced tumor angiogenic pathway and neck cancer: an in vivo study. Cancer Lett. 2005, 225, 297.

[90] Sephel GC, Woodward SC. Repair, regeneration and fibrosis, In: Rubin R, Strayer DS (eds), Rubin's Pathology: Clinicopathologic foundations of medicine (5th ed.) 2008, Philadeplphia: Lippincott Williams \& Wilkins, p. 71.

[91] Distler O, Neidhart M, Gay RE, Gay S. The molecular control of angiogenesis. Int. Rev. Immunol. 2002, 21, 33.

[92] Pardue EL, Ibrahim S, Ramamurthi A. Role of hyaluronan in angiogenesis and its utility to angiogenic tissue engineering. Organogenesis 2008, 4, 203.

[93] Bayat A, McGrouther DA, Ferguson MWJ. Skin scarring. BMJ 2003, 326, 88.

[94] Eming SA, Krieg T, Davidson JM. Inflammation in wound repair: molecular and cellular mechanisms. J. Inv. Derm. 2007, 127, 514.

[95] Singh $A B$, Harris RC. Autocrine, paracrine and juxtacrine signaling by EGFR ligands. Cell. Signal. 2005, 17, 1183.

[96] Baraniak PR, McDevitt TC. Stem cell paracrine actions and tissue regeneration. Regen. Med. 2010, 5, 121.

[97] Shi ZD, Ji XY, Qazi H, Tarbell JM. Interstitial flow promotes vascular fibroblast, myofibroblast and smooth muscle cell motility in 3-D collagen I via upregulation of MMP-1. Am. J. Physiol. Heart Circ. Physiol. 2009, 297, H1225.

[98] $\mathrm{Ng} \mathrm{CP,} \mathrm{Hinz} \mathrm{B,} \mathrm{Swartz} \mathrm{MA.} \mathrm{Interstitial} \mathrm{fluid} \mathrm{flow} \mathrm{induces} \mathrm{myofibroblast}$ differentiation and collagen alignment in vitro. J. Cell Sci. 2005, 118, 4731.

[99] Deng J, Petersen BE, Steindler DA, Jorgensen ML, Laywell ED. Mesenchymal stem cells spontaneously express neural proteins in culture and are neurogenic after transplantation. Stem Cell 2006, 24, 1054.

[100] Hofstetter CP, Schwarz EJ, Hess D, Widenfalk J, el Manira A, Prockop DJ, Olson L. Marrow stromal cells form guiding strands in the injured spinal cord and promote recovery. PNAS 2002, 99, 2199.

[101] Kondo T, Johnson SA, Yoder MC, Romand R, Hashino E. Sonic hedgehog and retinoic acid synergistically promote sensory fate specification from bone marrowderived pluripotent stem cells. PNAS 2005, 102, 4789. 
[102] McBeath R, Pirone DM, Nelson CM, Bhadriraju K, Chen CS. Cell shape, cytoskeletal tension and RhoA regulate stem cell lineage commitment. Dev. Cell. 2004, 6, 483.

[103] Engler AJ, Sen S, Sweeney HL, Discher DE. Matrix elasticity directs stem cell lineage specification. Cell 2006, 126, 677.

[104] Discher DE, Janmey P, Wang YL. Tissue cells feel and respond to the stiffness of their substrate. Science 2005, 310, 1139.

[105] Ingber DE. Mechanobiology and diseases of mechanotransduction. Ann. Med. 2003, 35, 564.

[106] Chen CS. Mechanotransduction - a field pulling together? J. Cell. Sci. 2008, $121,3285$.

[107] Vogel V, Sheetz M. Local force and geometry sensing regulate cell functions. Nat. Rev. Mol. Cell. Biol. 2006, 7, 265.

[108] Zandi R, Larsen AB, Andersen P, Stockhausen MT, Poulsen HS. Mechanisms of oncogenic activation of the epidermal growth factor receptor. Cell. Signal. 2007, 19, 2013.

[109] Conway K, Price P, Harding KG, Jiang WG. The molecular and clinical impact of hepatocyte growth factor, its receptor, activators and inhibitors in wound healing. Wound Repair Regen. 2006, 14, 2.

[110] Nagy JA, Dvorak AM, Dvorak HF. VEGF-A and the induction of pathological angiogenesis. Annu. Rev. Pathol. 2007, 2, 251.

[111] Andrae J, Gallini R, Betsholtz C. Role of platelet-derived growth factors in physiology and medicine. Genes Dev. 2008, 22, 1276.

[112] Itoh N. The FGF families in humans, mice and zebrafish: their evolutional processes and roles in development, metabolism and disease. Biol. Pharm. Bull. 2007, 30, 1819.

[113] Jaffer U, Wade RG, Gourlay T. Cytokines in the systemic inflammatory response syndrome: a review. HSR Proc. Int. Care Cardiovasc. Anesth. 2010, 2, 161. [114] McNulty AL, Moutos FT, Weinberg JB, Guilak F. Enhanced integrative repair of the porcine meniscus in vitro by inhibition of interleukin-1 or tumor necrosis factor alpha. Arthritis Rheum. 2007, 56, 3033.

[115] Sudo K, Yamada Y, Saito K, Shimizu S, Ohashi H, Kato T, Moriwaki H, Ito H, Seishima M. THF-alpha and IL-6 signals from the bone marrow derived cells are necessary for normal murine liver regeneration. Biochim. Biophys. Acta 2008, 1782, 671.

[116] Hanada R, Hanada T, Sigl V, Schramek D, Penninger JM. RANKL/RANKbeyond bones. J. Mol. Med. (Berl) 2011, 89, 647. 
[117] Neve A, Corrado A, Cantatore FP. Osteoblast physiology in normal and pathological conditions. Cell Tissue Res. 2011, 343, 289.

[118] Chen X, Tian HM, Yu XJ. Bone delivers its energy information to fat and islets through osteocalcin. Orthop. Surg. 2012, 4, 114.

[119] Schwetz V, Pieber T, Obermayer-Pietsch B. The endocrine role of the skeleton: background and clinical evidence. Eur. J. Endocrinol. 2012, 166, 959.

[120] Krause C, Korchynski O, de Rooij K, Weidauer SE, de Gorter DJ, van Bezooijen RL, Hatsell S, Economides AN, Mueller TD, Löwik CW, ten Dijke P. Distinct modes of inhibition by sclerostin on bone morphogenetic protein and Wnt signaling pathways. $J$. Biol. Chem. 2010, 285, 41614.

[121] Lombardi G, di Somma C, Rubino M, Faggiano A, Vuolo L, Guerra E, Contaldi P, Savastano S, Colao A. The roles of parathyroid hormone in bone remodeling: prospects for novel therapeutics. J. Endocrinol. Invest. 2011, 34, 18.

[122] Robling AG, Niziolek PJ, Baldridge LA, Condon KW, Allen MR, Alam I, Mantila SM, Gluhak-Heinrich J, Bellido TM, Harris SE, Turner CH. Mechanical stimulation of bone in vivo reduces osteocyte expression of Sost/sclerostin. J. Biol. Chem. 2008, 283, 5866.

[123] Papanicolaou SE, Phipps RJ, Fyhrie DP, Genetos DC. Modulation of sclerostin expression by mechanical loading and bone morphogenetic proteins in osteogenic cells. Biorheology 2009, 46, 389.

[124] Gooi JH, Pompolo S, Karsdal MA, Kulkarni NH, Kalajzic I, McAhren SH, Han B, Onya JE, Ho PW, Gillespie MT, Walsh NC, Chia LY, Quinn JM, Martin TJ, Sims NA. Calcitonin impairs the anabolic effect of PTH in young rats and stimulates expression of sclerostin by osteocytes. Bone 2010, 46, 1486.

[125] Antonopoulos AS, Margaritis M, Shirodaria C, Antoniades C. Translating the effects of statins: from redox modulation to suppression of vascular wall inflammation. Thromb. Haemost. 2012, 108.

[126] de Palma C, Clementi E. Nitric oxide in myogenesis and therapeutic muscle repair. Mol. Neurobiol. 2012. PMID: 22821188.

[127] Forbes BE, McCarthy P, Norton RS. Insulin-like growth factor binding proteins: a structural perspective. Front. Endocrinol. (Lausanne) 2012, 3, 38.

[128] Zamora R, Azhar N, Namas R, Metukuri MR, Clermont T, Gladstone C, Hermus L, Megas C, Constantine G, Billiar TR, Fink MP, Vodovotz Y. Identification of a novel pathway of TGF- $\beta 1$ regulation by extracellular NAD+ in mouse macrophages: in vitro and in silico studies. J. Biol. Chem. 2012, PMID: 22829588

[129] Willems E, Cabral-Teixeira J, Schade D, Cai W, Reeves P, Bushway PJ, Lanier M, Walsh C, Kirchausen T, Izpisua Belmonte JC, Cashman J, Mercola M. Small 
molecule-mediated TGF- $\beta$ type II receptor degradation promotes cardiomyogenesis in embryonic stem cells. Cell Stem Cell 2012, 11, 242.

[130] Bierie B, Moses HL. Tumor microenvironment: TGFbeta, the molecular Jekyll and Hyde of cancer. Nat. Rev. Cancer 2006, 6, 506.

[131] Noble NA, Harper JR, Border WA. In vivo interactions of TGF-beta and extracellular matrix. Prog. Growth Factor Res. 1992, 4, 369.

[132] Bujak M, Frangogiannigs NG. The role of TGF- $\beta$ signaling in myocardial infarction and cardiac remodeling. Cardiovasc. Res. 2007, 74, 184.

[133] Ducy P, Karsenty G. The family of bone morphogenetic proteins. Kidney Int. 2000, 57, 2207.

[134] Reddi AH. BMPs: from bone morphogenetic proteins to body morphogenetic proteins. Cytok. Growth Fact. Rev. 2005, 16, 249.

[135] Ripamonti U, Heliotis M, Ferretti C. Bone morphogenetic proteins and the induction of bone formation: from laboratory to patients. Oral Maxillofac. Surg. Clin. North Am. 2007, 19, 575.

[136] MacKay WF, Peckham SM, Badura JM. A comprehensive clinical review of recombinant human bone morphogenetic protein-2 (INFUSE ${ }^{\circledR}$ Bone graft). Int. Orthop. (SICOT) 2007, 31, 729.

[137] Dooley C, Tisbo P, Lee TC, Taylor D. Rupture of osteocyte processes across microcracks: the effect of crack length and stress. Biomech. Model Mechanobiol. 2012, 11, 759 .

[138] Herman BC, Cardoso L, Majeska RJ, Jespen KJ, Schaffer MB. Activation of bone remodeling after fatigue: differential response to linear microcracks and diffuse damage. Bone 2010, 47, 766.

[139] Verbogt O, Gibson GJ, Schaffer MB. Loss of osteocyte integrity in association with microdamage and bone remodeling after fatigue in vivo. J. Bone Miner. Res. 2000, 15,60 .

[140] Kennedy OD, Herman BC, Laudier DM, Majeska RJ, Sun HB, Schaffler MB. Activation of resorption in fatigue-loaded bone involves both apoptosis and active proosteoclastogenic signaling by distinct osteocyte populations. Bone 2012, 50, 1115.

[141] Rochefort GY, Pallu S, Benhamou CL. Osteocyte: the unrecognized side of bone tissue. Osteoporos. Int. 2010, 21, 1457.

[142] Fukazawa T, Matsuoka J, Yamatsuji T, Maeda Y, Durbin ML, Naomoto Y. Adenovirus-mediated cancer gene therapy and virotherapy - review. Int. J. Mol. Med. 2010, 25, 3.

[143] Touchefeu Y, Harrington KJ, Galmiche JP, Vassaux G. Review article: gene therapy, recent developments and future prospects in gastrointestinal oncology. Aliment. Pharmacol.Ther. 2010, 32, 953. 
[144] Mullard A. Gene therapies advance towards finish line. Nature Reviews 2011, 10,719 .

[145] Byrant JS, Duker JS, Reichel E. Gene therapy for retinal disease. Rev. Opht. Online 2012, retrieved on 17 July 2012 from the website www.revophth.com.

[146] Zischek C, Niess H, Ischenko I, Conrad C, Huss R, Jauch KW, Nelson PJ, Bruns $C$. Targeting tumor stroma using engineered mesenchymal stem cells reduces the growth of pancreatic carcinoma. Ann. Surg. 2009, 250, 747.

[147] Jaglowski SM, Byrd JC. Novel therapies and their integration into allogeneic stem cell transplant for chronic lymphocytic leukemia. Biol. Blood Marrow Transplant 2012, 18, S132.

[148] Müller LU, Schlaeger TM, Devine AL, Williams DA. Induced pluripotent stem cells as a tool for gaining new insights into Fanconi anemia. Cell Cycle 2012, 11.

[149] Kim SU, de Vellis J. Stem cell-based therapy in neurological diseases: a review. J. Neurosci. Res. 2009, 87, 2183.

[150] Haraguchi Y, Shimizu T, Yamato M, Okano T. Concise review: cell therapy and tissue engineering for cardiovascular disease. Stem Cells Trans. Med. 2012, 1, 136.

[151] Giannoudis PV, Dinopoulos H, Tsiridis E. Bone substitutes: an update. Injury Int. J. Care Injured 2005, 36, s20.

[152] Dalby MJ, Gadegaard N, Riehle MO, Wilkinson CDW, Curtis ASG. Investigating filopodia sensing using arrays of defined nano-pits down to $35 \mathrm{~nm}$ diameter in size. Int. J. Biochem. Cell. Biol. 2004, 36, 2005.

[153] Webster TJ, Schadler LS, Siegel RW, Bizios R. Mechanism of enhanced osteoblast adhesion on nanophase alumina involve vitronectin. Tissue Engineering 2001, 7, 291.

[154] Stevens MM, George JH. Exploring and engineering the cell surface interface. Science 2005, 310, 1135.

[155] Atala A, Bauer SB, Soker S, Yoo JJ, Retik AB. Tissue engineered autologous bladders for patients needing cystoplasty. Lancet 2006, 367, 1241.

[156] Macchiarini P, Jungebluth P, Go T, Asnaghi MA, Rees LE, Cogan TA, Dodson A, Martorell J, Bellini S, Parnigotto PP, Dickinson SC, Hollander PA, Mantero S, Conconi MT, Birchall MA. Clinical transplantation of a tissue engineered airway. Lancet 2008, 372, 2023.

[157] Autumn K, Liang YA, Hsieh ST, Zesch W, Chan WP, Kenny TW, Fearing R, Full RJ. Adhesive force of a single gecko foot-hair. Nature 2000, 405, 681.

[158] Pennisi E. Biomechanics. Geckos climb by the hairs of their toes. Science 2000, 288, 1717. 
[159] Autumn K, Sitti M, Liang YA, Peattie AM, Hansen WR, Sponberg S, Kenny TW, Fearing R, Israelachvili JN, Full RJ. Evidence for van der Waals adhesion in gecko setae. PNAS 2002, 99, 12252.

[160] Sun W, Neuzil P, Kustandi TS, Oh S, Samper VD. The nature of the gecko lizard adhesive force. Biophys. J. 2005,89, L14.

[161] Huber G, Mantz H, Spolenak R, Mecke K, Jacobs K, Gorb SN, Arzt E. Evidence for capillarity contributions to gecko adhesion from single spatula nanomechanical measurements. PNAS 2005, 102, 16293.

[162] Ge L, Sethi S, Ci L, Ajayan PM, Dhinojwala A. Carbon nanotube-based synthetic gecko tapes. PNAS 2007, 104, 10792.

[163] Geim AK, Dubonos SV, Grigorieva IV, Novoselov KS, Zhukov AA, Shapoval SY. Microfabricated adhesive mimicking gecko foot-hair. Nat. Mater. 2003, 2, 461.

[164] Lee H, Lee BP, Messersmith PB. A reversible wet/dry adhesive inspired by mussels and geckos. Nature 2007, 448, 338.

[165] Mahdavi A, Ferreira L, Sundback C, Nichol JW, Chan EP, Carter DJD, Bettinger CJ, Patanavanich S, Chignozha L, Ben-Joseph E, Galakatos A, Pryor H, Pomerantseva I, Masiakos PT, Faquin W, Zumbuehl A, Hong S, Borenstein J, Vacanti J, Langer R, Karp JM. A biodegradable and biocompatible gecko-inspired tissue adhesive. PNAS 2008,105, 2307.

[166] Mueller T. Biomimetics: design by Nature. National Geographic 2008 (April), 68. [167] Bhushan B. Biomimetics: lessons from nature - an overview. Phil. Trans. R. Soc. A 2009, 367, 1445.

[168] Abele R. The new lightness: new materials and design principles for improving energy efficiency. Technicity Magazine (edited by Daimler) 2010, 2, 62.

[169] Howle LE. WhalePower Wenvor blade. A report in the efficiency of a WhalePower Corp. 5 meter prototype wind turbine blade. 2009, BelleQuant Engineering, PLLC.

[170] Donati D, Zolezzi C, Tomba P, Viganò A.Bone grafting: historical and conceptual review, starting with an old manuscript by Vittorio Putti. Acta Orthopaedica 2007, 78, 19.

[171] Nerlich AG, Zink A, Szeimies U, Hagedorn HG. Ancient Egyptian prosthesis of the big toe. Lancet 2000, 356, 2176.

[172] Finch J. The ancient origins of prosthetic medicine. Lancet 2011, 377, 548.

[173] Sawaya F, Liff D, Stewart J, Lerakis S, Babaliaros V. Aortic stenosis: a contemporary review. Am. J. Med. Sci. 2012, 343, 490.

[174] Courpied JP, Caton JH. Total hip arthroplasty, state of the art for the $21^{\text {st }}$ century. Int. Orthop. 2011, 35, 149. 
[175] Goodman SL, Sims PA, Albrecht RM. Three-dimensional extracellular matrix textured biomaterials. Biomaterials 1996, 17, 2087.

[176] Abrams GA, Goodman SL, Nealey PF, Franco M, Murphy CJ. Nanoscale topography of the basement membrane underlying the corneal epithelium of the rhesus macaque. Cell Tissue Res. 2000, 299, 39.

[177] Pamula E, de Cupere V, Dufrêne YF, Rouxhet PG. Nanoscale organization of adsorbed collagen: influence of substrate hydrophobicity and adsorption time. J. Colloid Interface Sci. 2004, 271, 80.

[178] Bozec L, van der Heijden G, Horton M. Collagen fibrils: nanoscale ropes. Biophys. J. 2007, 92, 70.

[179] Wolf K, Müller R, Borgmann S, Bröcker EB, Friedl P. Amoeboid shape change and contact guidance: T-lymphocyte crawling through fibrillar collagen is independent of matrix remodeling by MMPs and other proteases. Blood 2003, 102, 3262.

[180] Sutherland J, Denyer M, Britland S. Contact guidance in human dermal fibroblasts is modulated by population pressure. J. Anat. 2005, 206, 581.

[181] Chou L, Firth JD, Uitto VJ, Brunette DM. Substratum surface topography alters cell shape and regulates fibronectin mRNA level, mRNA stability, secretion and assembly in human fibroblasts. J. Cell. Sci. 1995, 108, 1563.

[182] Oakley C, Brunette DM. Response of single, pairs and clusters of epithelial cells to substratum topography. Biochem. Cell Biol. 1995, 73, 473.

[183] Qu J, Chehroudi B, Brunette DM. The use of micromachined surfaces to investigate the cell behavioral factors essential to osseointegration. Oral Dis. 1996, 2, 102.

[184] Brunette DM, Chehroudi B. The effects of the surface topography of micromachined titanium substrata on cell behavior in vitro and in vivo. J. Biomech. Eng. 1999, 121, 49.

[185] Choi CH, Hagvall SH, Wu BM, Dunn JCY, Beygui RE, Kim CJ. Cell interaction with three-dimensional sharp-tip nanotopography. Biomaterials 2007, 28, 1672.

[186] Bettinger CJ, Zhang Z, Gerecht S, Borenstein JT, Langer R. Enhancement of in vitro capillary tube formation by substrate nanotopography. Adv. Mater. 2008, 20, 99.

[187] Gerecht S, Bettinger CJ, Zhang Z, Borenstein JT, Vunjak-Novakovic G, Langer $R$. The effect of actin disrupting agents on contact guidance of human embryonic stem cells. Biomaterials 2007, 28, 4068.

[188] Yim EKF, Reano RM, Pang SW, Yee AF, Chen CS, Leong KW. Nanopatterninduced changes in morphology and motility of smooth muscle cells. Biomaterials 2005, 26, 5405. 
[189] Teixeira AI, McKie GA, Foley JD, Bertics PJ, Nealey PF, Murphy CJ. The effect of environmental factors on the response of human corneal epithelial cells to nanoscale substrate topography. Biomaterials. 2006, 27, 3945.

[190] Rajnicek AM, Foubister LE, McCaig CD. Prioritising guidance cues: directional migration induced by substratum contours and electrical gradients is controlled by a rho/cdc42 switch. Dev. Biol. 2007, 312, 448.

[191] Yim EKF, Pang SW, Leong KW. Synthetic nanostructures inducing differentiation of human mesenchymal stem cells into neuronal lineage. Exp. Cell Res. 2007, 313, 1820.

[192] Biggs M, Richards R, Gadegaard N, Wilkinson C, Dalby MJ. The effects of nanoscale pits on primary human osteoblast adhesion formation and cellular spreading. J. Mater. Sci. Mater. Med. 2007, 18, 399.

[193] Curtis ASG, Gadegaard N, Dalby MJ, Riehle MO, Wilkinson C, Aitchison GA. Cells react to nanoscale order and symmetry in their surroundings. IEEE Trans. NanoBiosci. 2004, 3, 61.

[194] Milner KR, Siedlecki CA. Submicron poly(L-lactic acid) pillars affect fibroblast adhesion and proliferation. J. Biomed. Mater.Res. A. 2007, 82, 80.

[195] Dalby MJ, Gadegaard N, Tare R, Andar A, Riehle MO, Herzyk P, Wilkinson C, Oreffo ROC. The control of human mesenchymal cell differentiation using nanoscale symmetry and disorder. Nat. Mater. 2007, 6, 997.

[196] Hart A, Gadegaard N, Wilkinson C, Oreffo ROC, Dalby MJ. Osteoprogenitor response to low-adhesion nanotopographies originally fabricated by electron beam lithography. J. Mater. Sci. Mater. Med. 2007, 18, 1211.

[197] Fu J, Wang YK, Yang MT, Desai RA, Yu X, Liu Z, Chen CS. Mechanical regulation of cell function with geometrically modulated elastomeric substrates. Nat. Met. 2010, 7, 733.

[198] Green DW, Watson GS, Watson J, Abraham SJK. New biomimetic directions in regenerative ophthalmology. Adv. Healthcare Mater. 2012, 1, 140.

[199] Kim S, Ku SH, Lim SY, Kim JH, Park CB. Graphene-biomineral hybrid materials. Adv. Mater. 2011, 23, 2009.

[200] Segman-Magidovich S, Grisaru H, Gitli T, Levi-Kalisman Y, Rapaport H. Matrices of acidic $\beta$-sheet peptides as templates for calcium phosphate mineralization. Adv. Mater. 2008, 20, 2156.

[201] Cushing MC, Anseth KS. Hydrogel cell cultures. Science 2007, 316, 1133. [202] Liu SQ, Tian Q, Hedrick JL, Po-Hui JH, Ee PL, Yang YY. Biomimetic hydrogels for chondrogenic differentiation of human mesenchymal stem cells to neocartilage. Biomaterials 2010, 31, 7298. 
[203] Ng SP, Billings KS, Ohashi T, Allen MD, Best RB, Randles LG, Erickson HP, Clarke J. Designing an extracellular matrix protein with enhanced mechanical stability. PNAS 2007, 104, 9633.

[204] Shih YRV, Chen CN, Tsai SW, Wang YJ, Lee OK. Growth of mesenchymal stem cells on electrospun type I collagen naniofibers. Stem Cells 2006, 24, 2391.

[205] McKee MG, Layman JM, Cashion MP, Long TE. Phospholipid nonwoven electrospun membranes. Science 2006, 311, 353.

[206] Jean A, Engelmayr Jr. GC. Anisotropic collagen fibrillogenesis within microfabricated scaffolds: implications for biomimetic tissue engineering. Adv. Healthcare Mater. 2012, 1, 112.

[207] Liu W, Thomopoulos S, Xia Y. Nanofibers in regenerative medicine: electrospun nanofibers for regenerative medicine. Adv. Healthcare Mater. 2012, 1, 2.

[208] Moroni L, Licht R, de Boer J, de Wijn J, van Blitterswijk CA. Fiber diameter and texture of electrospun PEOT/PBT scaffold influence human mesenchymal stem cell proliferation and morphology, and the release of incorporated compounds. Biomaterials 2006, 27, 4911.

[209] Woodfield TB, Malda J, de Wijn J, Péters F, Riesle J, van Blitterswijk CA. Design of porous scaffolds for cartilage tissue engineering using a three-dimensional fiber-deposition technique. Biomaterials 2004, 25, 4149.

[210] Nuttelman CR, Mortisen DJ, Hnery SM, Anseth KS. Attachment of fibronectin to poly(vinyl alcohol) hydrogels promotes NIH3T3 cell adhesion, proliferation and migration. J. Biomed. Mater. Res. 2001, 57, 217.

[211] Schofer MD, Veltum A, Theisen C, Chen F, Agarwal S, Fuchs-Winkelmann S, Paletta JR. Functionalisation of PLLA nanofiber scaffolds using a possible cooperative effect between collagen type I and BMP-2: impact on growth and osteogenic differentiation of human mesenchymal stem cells. J. Mater. Sci. Meter. Med. 2011, 22, 1753.

[212] Jurga M, Dainiak MB, Sarnowska A, Jablonska A, Tripathi A, Plieva IN, Strojek L, Junqvid H, Kumar A, Lukomska B, Domanska-Janik K, Forraz N, McGuckin CP. The performance of laminin-containing cryogel scaffolds in neural tissue regeneration. Biomaterials 2011, 32, 3423.

[213] Liu Y, Li N, Qi YP, Dai L, Bryan TE, Mao J, Pashley DH, Tay FR. Intrafibrillar collagen mineralization produced by biomimetic hierarchical nanoapatite assembly. Adv. Mater. 2011, 23, 975.

[214] Collins AM, Skaer NJV, Gheysens T, Knight D, Betram C, Roach HI, Oreffo ROC, von Aulock S, Baris T, Skinner J, Mann S. Bone-like resorbable silk-based scaffold for load-bearing osteoregenerative applications. Adv. Mater. 2009, 21, 75. 
[215] Tang L, Jennings TA, Eaton JW. Mast cells mediate acute inflammatory responses to implanted biomaterials. PNAS 1998, 95, 8841.

[216] Anderson JM, Rodriguez A, Chang DT. Foreign body reaction to biomaterials. Semin. Immunol. 2008, 20, 86.

[217] de Bruijn JD, Yuan H. Osteoinductive calcium phosphate. European Patent EP1829564, 2006.

[218] Yang ZJ, Yuan H, Zou P, Tong W, Qu S, Zhang X. Osteogenic responses to extraskeletally implanted synthetic porous calcium phosphate ceramics: an early stage histomorphological study in dogs. J. Mater. Sci. Mater. Med. 1997, 8, 697.

[219] Yuan $\mathrm{H}$, van Blitterswijk CA, de Groot K, de Bruijn JD. A comparison of bone formation in biphasic calcium phosphate (BCP) and hydroxyapatite $(\mathrm{HA})$ implanted in muscle and bone of dogs at different time periods. J. Biomed. Mater. Res. A 2006, 78, 139.

[220] Kondo N, Ogose A, Tokunaga K, Umezu H, Arai K, Kudo N, Hoshino M, Inoue $\mathrm{H}$, Irie $\mathrm{H}$, Kuroda $\mathrm{K}$, Mera K, Endo N. Osteoinduction with highly purified betatricalcium phosphate in dog dorsal muscles and the proliferation of osteoclasts before heterotopic bone formation. Biomaterials 2006, 27, 4419.

[221] Winter GD, Simpson BJ. Heterotopic bone formed in a synthetic sponge in the skin of young pigs. Nature 1969, 223, 88.

[222] Yamasaki H. Heterotopic bone formation around porous hydroxyapatite ceramics in the subcuits of dogs. Jpn. J. Oral. Biol. 1990, 32, 190.

[223] Klein C, de Groot K, Chen W, Li Y, Zhang X. Osseous substance formation induced in porous calcium phosphate ceramics in soft tissues. Biomaterials 1994, 15, 31.

[224] Pollick S, Shors EC, Holmes RE, Kraut RA. Bone formation and implant degradation of coralline porous ceramics placed in bone and ectopic sites. J. Oral. Maxillofac. Surg. 1995, 53, 915.

[225] Ripamonti U. Osteoinduction in porous hydroxyapatite implanted in heterotopic sites of different animal models. Biomaterials 1996, 17, 31.

[226] Yuan H, Yang Z, Li Y, Zhang X, de Bruijn JD, de Groot K. Osteoinduction by calcium phosphate biomaterials. J. Mater. Sci: Mater. Med. 1998, 9, 723.

[227] Ripamonti U, Crooks J, Kirkbride AN. Sintered porous hydroxyapatites with intrinsic osteoinductive activity: geometric induction of bone formation. S. Afr. J. Sci. 1999, 95, 335.

[228] Habibovic P, Yuan H, van der Valk CM, Meijer G, van Blitterwijk CA, de Groot K. 3D microenvironment as essential element for osteoinduction by biomaterials. Biomaterials 2005, 26, 3565. 
[229] Yuan H, Li Y, de Bruijn JD, de Groot K, Zhang X. Tissue responses of calcium phosphate cement: a study in dogs. Biomaterials 2000, 21, 1283.

[230] Gosain AK, Song L, Riordan P, Amarante MT, Nagy PG, Wilson CR, Toth JM, Ricci JL.A 1-year study of osteoinduction in hydroxyapatite-derived biomaterials in adult sheep model: part I. Plast. Reconstr. Surg. 2002, 109, 619.

[231] de Bruijn JD, Yuan H, Dekker R, Layrolle P, de Groot K, van Blitterswijk CA. Osteoinductive biomimetic calcium-phosphate coatings and their potential use as tissue-engineering scaffolds. In: Bone Engineering (JE Davies, ed), EM Square Inc, Toronto, 2000, 421.

[232] Barrère F, van der Valk CM, Dalmeijer RA, Meijer G, van Blitterswijk CA, de Groot K, Layrolle P. Osteogenecity of octacalcium phosphate coatings applied on porous metal implants. J. Biomed. Mater. Res. A 2003, 66, 779.

[233] Yuan H, de Bruijn JD, Zhang X, van Blitterswijk CA, de Groot K. Bone induction by porous glass ceramic made from Bioglass (45S5). J. Biomed. Mater.Res. 2001, 58, 270.

[234] Fujibayashi S, Neo M, Kim HM, Kokubo T, Nakamura T. Osteoinduction of porous bioactive titanium metal. Biomaterials 2004, 25, 443.

[235] Hasegawa S, Neo M, Tamura J, Fujibayashi S, Takemoto M, Shikinami Y, Okazaki K, Nakamura T. In vivo evaluation of a porous hydroxyapatite/poly-D,Llactide composite for bone tissue engineering. J. Biomed. Mater.Res. A 2007, 81, 930. [236] Yamasaki H, Sakai H. Osteogenic response to porous hydroxyapatite ceramics under the skin of dogs. Biomaterials 1992, 13, 308.

[237] Yuan H, Kurashina K, de Bruijn JD, Li Y, de Groot K, Zhang X. A preliminary study on osteoinduction of two kinds of calcium phosphate ceramics. Biomaterials 1999, 20, 1799.

[238] Habibovic P, Yuan H, van den Doel M, Sees TM, van Blitterswijk CA, de Groot $\mathrm{K}$. Relevance of osteoinductive biomaterials in critical-sized orthotopic defect. J. Orthop. Res. 2006, 24, 867.

[239] Deng X, Hao J, Wang C. Preparation and mechanical properties of nanocomposites of poly(D,L-lactide) with Ca-deficient hydroxyapatite nanocrystals. Biomaterials 2001, 22, 2867.

[240] Nejati E, Mirzadeh H, Zandi M. Synthesis and characterization of nanohydroxyapatite rods/poly(L-lactic acid) composite scaffold for bone tissue engineering. Composites Part A 2008, 39, 1589.

[241] Verheyen CC, de Wijn JR, van Blitterswijk CA, de Groot K, Rozing PM. Hydroxyapatite/poly(L-lactide) composites: an animal study on push-out strengths and interface histology. J. Biomed. Mater. Res. 1993, 27, 433. 
[242] Wei G, Ma PX. Structure and properties of nano-hydroxyapatite/polymer composite scaffolds for bone tissue engineering. Biomaterials 2004, 25, 4749. [243] Lin PL, Fang HW, Tseng T, Lee WH. Effects of hydroxyapatite dosage on mechanical and biological behaviors of polylactic acid composite materials. Mat. Lett. 2007, 61, 3009.

[244] le Nihouannen D, Saffarzadeh A, Aguado E, Goyenvalle E, Gauthier O, Moreau F, Pilet P, Spaethe R, Daculsi G, Layrolle P. Osteogenic properties of calcium phosphate ceramics and fibrin glue based composites. J. Mater. Sci. Mater. Med. 2007, 18, 225.

[245] Kokubo T, Kim HM, Kawashita M, Nakamura T. What kinds of materials exhibit bone-bonding? In: Davies JE (ed), Bone Engineering 2000, Toronto: EM Square Inc., 190.

[246] LeGeros RZ. Calcium phosphate-based osteoinductive materials. Chem. Rev. 2008, 108, 4742.

[247] Kokubo T, Takadama H. How useful is SBF in predicting in vivo bone bioactivity? Biomaterials 2006, 27, 2907.

[248] Kokubo T, Kim HM, Kawashita M. Novel bioactive materials with different mechanical properties. Biomaterials 2003, 24, 2161.

[249] LeGeros RZ. Properties of osteoconductive biomaterials: calcium phosphates. Clin. Orthop.Relat.Res. 2002, 395, 81.

[250] Boix T, Gómez-Morales J, Torrent-Burgués J, Monfort A, Puigdomènech P, Rodríguez-Clemente R. Adsorption of recombinant human bone morphogenetic protein rhBMP-2m onto hydroxyapatite. J. Inorg. Biochem. 2005, 99, 1043.

[251] Yuan H, van Blitterswijk CA, de Groot K, de Bruijn JD. Ectopic bone formation by microstructured synthetic materials through in vivo protein adsorption. In: Trans. 31st. Ann. Meet. Soc. Biomaterials, Vol. XXIX 2006, 609.

[252] Ducheyne P, Qiu Q. Bioactive ceramics: the effect of surface reactivity on bone formation and bone cell function. Biomaterials 1999, 20, 2287.

[253] Habibovic P, Bassett DC, Doillon CJ, Gerard C, McKee MD, Barralet JE. Collagen biomineralizaion in vivo by sustained release of inorganic phosphate ions. Adv. Mater. 2010, 22, 1858.

[254] Fellah BH, Josselin N, Chappard D, Weiss P, Layrolle P. Inflammatory reaction in rats muscle after implantation of biphasic calcium phosphate micro particles. $J$. Mater. Sci. Mater. Med. 2007, 18, 287.

[255] Bota PCS, Collie AMB, Puolakkainen P, Vernon RB, Sage EH, Ratner BD, Stayton PS. Biomaterial topography alters healing in vivo and monocyte/macrophage activation in vitro. J. Biomed. Mater. Res. A 2010, 95, 649. 
[256] Fellah BH, Delorme B, Sohier J, Magne D, Hardouin P, Layrolle P. Macrophage and osteoblast responses to biphasic calcium phosphate microparticles. J. Biomed. Mater. Res. A 2010, 93, 1588.

[257] Xia Z, Triffitt JT. A review on macrophage responses to biomaterials. Biomed. Mater. 2006, 1, 1.

[258] Anscomb A. Orthopedic Biomaterials. The World Market Kalorama Information Market Intelligence Reports. New York: Kalorama Information; 2011.

[259] Patel VV, Zhao L, Wong P, Kanim L, Bae HW, Pradhan BB, Delamarter RB. Controlling bone morphogenetic protein diffusion and bone morphogenetic proteinstimulated bone growth using fibrin glue. Spine 2006, 31, 1201.

[260] Yuan H, de Groot K. In: Reis RL, Weiner S (eds.) Learning from nature how to design new implantable biomaterials. Kluwer Academic Publishers (Dordrecht, the Netherlands), ISBN 1-4020-2644-7, 2004, 37.

[261] Navarro M, Michiardi A, Castaño O, Planell JA. Biomaterials in orthopaedics. J. R. Soc. Interface 2008, 5, 1137.

[262] le Nihouannen D, Daculsi G, Saffarzadeh A, Gauthier O, Delplace S, Pilet P, Layrolle $P$. Ectopic bone formation by microporous calcium phosphate ceramic particles in sheep muscles. Bone 2005, 36, 1086.

[263] Habibovic P, Sees TM, van den Doel MA, van Blitterswijk CA, de Groot K. Osteoinduction by biomaterials - physicochemical and structural influences. J. Biomed. Mater. Res. A 2006, 77, 747.

[264] Ginebra MP, Fernandez E, Boltong MG, Bermúdez O, Planell JA, Driessens FC. Compliance of an apatitic calcium phosphate cement with the short-term clinical requirements in bone surgery, orthopaedics and dentistry. Clin. Mater. 1994, 17, 99.

[265] Mirtchi AA, Lemaitre J, Terao N. Calcium phosphate cements: study of the betatricalcium phosphate-monocalcium phosphate system. Biomaterials 1989, 10, 475.

[266] Comuzzi L, Ooms E, Jansen JA. Injectable calcium phosphate cement as a filler for bone defects around oral implants: an experimental study in goats. Clin. Oral. Implants Res. 2002, 13, 304.

[267] Roemhildt ML, Wagner SD, McGee TD. Characterization of a novel calcium phosphate composite bone cement: flow, setting and aging properties. J. Mater. Sci. Mater. Med. 2006, 17, 1127.

[268] Félix Lanao RP, Leeuwenburgh SC, Wolke JG, Jansen JA. Bone response tof ast-degrading, injectable calcium phosphate cements containing PLGA microparticles. Biomaterials 2011, 32, 8839.

[269] Bodde EW, Cammaert CT, Wolke JG, Spauwen PH, Jansen JA. Investigation as to the osteoinductivity of macroporous calcium phosphate cement in goats. $\mathrm{J}$. Biomed. Mater. Res. B Appl. Biomater. 2007, 83, 161. 
[270] Atkinson BL, Hanks TS. Bone repair putty comprising porous particulate and carrier gel. WO patent No. WO2004/011053 A1 2004.

[271] Gertzman AA, Sunwoo MH. Malleable bone composition for filling bone defects. EU patent No. EP1477176 A1 2004.

[272] Trojani C, Boukhechba F, Scimeca JC, Vandenbos F, Michiels JF, Daculsi G, Boileau P, Weiss P, Carle GF, Rochet N. Ectopic bone formation using an injectable biphasic calcium phosphate/Si-HPMC hydrogel composite loaded with undifferentiated bone marrow stromal cells. Biomaterials 2006, 27, 3256.

[273] Ambrosio L, Sanginario V, Ginebra MP, Planell JA. Injectable composite material suitable for use as a bone substitute. WO patent No. WO2007/015208 A2 2007.

[274] Balaguer T, Boukhechba F, Clavé A, Bouvet-Gerbettaz S, Trojani S, Michiels JF, Laugier JP, Bouler JM, Carle GF, Scimeca JC, Rochet N. Biphasic calcium phosphate microparticles for bone formation: benefits of combination with blood clot. Tissue Eng. Part A 2010, 16, 3495.

[275] Engelhardt SA. In: Orthopaedic product News, May/June 2008, 50. Available online from URL: http://www.orthoworld.com/site/docs/opn/us_opn-2008-06.pdf (retrieved on 23 June 2010).

[276] Fedorovich NE, Alblas J, de Wijn JR, Hennik WE, Verbout AJ, Dhert WJ. Hydrogels as extracellular matrices for skeletal tissue engineering: state-of-the-art and novel application in organ printing. Tissue Eng. 2007, 13, 1905.

[277] Reza AT, Nicoll SB. Characterization of novel photocrosslinked carboxymethylcellulose hydrogels for encapsulation of nucleus pulposus cells. Acta Biomater. 2010, 6, 179.

[278] Escobar-Chávez JJ, López-Cervantes M, Naïk A, Kalia YN, Quintanar-Guerrero D, Ganem-Quintanar A. Applications of thermo-reversible pluronic F-127 gels in pharmaceutical formulations. J. Pharm. Pharm. Sci. 2006, 9, 339.

[279] Mallapragada SK, McCarthy-Schroeder S. In Wise DL (ed.). Handbook of pharmaceutical controlled release technology, Marcel Dekker, 2000, 31.

[280] Peterson RC, Wolffsohn JS, Nick J, Winterton L, Lally J. Clinical performance of daily disposable soft contact lenses using sustained release technology. Cont. Lens Anterior Eye 2006, 29, 127.

[281] Ong SY, Wu J, Moochhala SM, Tan MH, Lu J. Development of a chitosanbased wound dressing with improved hemostatic and antimicrobial properties. Biomaterials 2008, 29, 4323.

[282] Diduch DR, Jordan LC, Mierisch CM, Balian G. Marrow stromal cells embedded in alginate for repair of osteochondral defects. Arthroscopy 2000, 16, 571. 
[283] Bent AE, Tutrone RT, McLennan MT, Lloyd LK, Kennelly MJ, Badlani G. Treatment of intrinsic sphincter deficiency using autologous ear chondrocytes as a bulking agent. Neurourol. Urodyn. 2001, 20, 157.

[284] Yuan H, de Groot K, van Blitterswijk CA, de Bruijn JD. Preparation of a resorbable osteoinductive tricalcium phosphate ceramic. Eur. Cells Mater. 2008, 16 (suppl. 2), 14.

[285] Clayton HA, London NJ, Colloby PS, Bell PR, James RF. The effect of capsule composition on the biocompatibility of alginate-poly-L-lysine capsules. J. Microencapsulation 1991, 6, 221.

[286] de Vos P, de Haan B, van Schilfgaarde R. Effect of the alginate composition on the biocompatibility of alginate-polylysine microcapsules. Biomaterials 1997, 18, 273.

[287] Otterlei M, Ostgaard K, Skjåk-Bræk G, Smidsrød O, Soon-Shiong P, Espevik T. Induction of cytokine production from human monocytes stimulated with alginate. $J$. Immunother. 1991, 10, 286.

[288] Rowley JA, Madlambayan G, Mooney DJ. Alginate hydrogels as synthetic extracellular matrix materials. Biomaterials 1999, 20, 45.

[289] Augst AD, Kong HJ, Mooney DJ. Alginate hydrogels as biomaterials. Macromol. Biosci. 2006, 6, 623.

[290] Huang JW, Chen WJ, Liao SK, Yang CY, Lin SS, Wu CC. Osteoblastic differentiation of rabbit mesenchymal stem cells loaded in a carrier system of Pluronic F127 and Interpore. Chang Gung Med. J. 2006, 29, 363.

[291] Reynolds MA, Aichelmann-Reidy ME, Kassolis JD, Prasad HS, Rohrer MD. Calcium sulfate-carboxymethylcellulose bone graft binder: histologic and morphometric evaluation in a critical size defect. J. Biomed. Mater. Res. B Appl. Biomater. 2007, 83, 451.

[292] Daculsi G, Rohanizadeh R, Weiss P, Bouler JM. Crystal polymer interaction with new injectable bone substitute: SEM and HR-TEM study. J. Biomed. Mater. Res. $2000,50,1$.

[293] Bohner M. Design of ceramic-based cements and putties for bone graft substitution. Eur. Cell. Mater. 2010, 20, 1.

[294] LeGeros RZ. Biodegradation and bioresorption of calcium phosphate ceramics. Clin. Mater. 1993, 14, 65.

[295] Davison N, Yuan H, de Bruijn JD, Barrère-de Groot F. In vivo performance of microstructured calcium phosphate formulated in novel water-free carriers. Acta Biomater. 2012, 8, 2759.

[296] Habibovic P, Juhl MV, Clyens S, Martinetti R, Dolcini L, Theilgaard N, van Blitterswijk CA. Comparison of two carbonated apatite ceramics in vivo. Acta Biomater. 2010, 6, 2219. 
[297] Sato I, Akizuki T, Oda S, Tsuchioka H, Hayashi C, Takasaki AA, Mizutani K, Kawakatsu N, Kinoshita A, Ishikawa I, Izumi Y. Histological evaluation of alveolar ridge augmentation using injectable calcium phosphate bone cement in dogs. J. Oral. Rehabil. 2009, 36, 762.

[298] Kwon B, Jenis LG. Carrier materials for spinal fusion. Spine J. 2005, 5, $224 S$.

[299] Boakye M, Mummaneni PV, Garrett M, Rodts G, Haid R. Anterior cervical discectomy and fusion involving a polyetheretherketone spacer and bone morphogenetic protein. J. Neurosurg. Spine 2005, 2, 521.

[300] Kroese-Deutmann HC, Quinten Ruhé P, Spauwen PHM, Jansen JA. Bone inductive properties of rhBMP-2 loaded porous calcium phosphate cement implants inserted at ectopic site in rabbits. Biomaterials 2005, 26, 1131.

[301] Hsu HP, Zanella JM, Peckham SM, Spector M. Comparing ectopic bone growth induced by rhBMP-2 on an absorbable collagen sponge in rat and rabbit models. J. Orthop. Res. 2006, 24, 1660.

[302] Kim CS, Kim JI, Kim J, Choi SH, Chai JK, Kim CK, Cho KS. Ectopic bone formation associated with recombinant human morphogenetic protein-2 using absorbable collagen sponge and beta tricalcium phosphate as carriers. Biomaterials 2005, 26, 2501.

[303] Fellah BH, Gauthier O, Weiss P, Chappard D, Layrolle P. Osteogenicity of biphasic calcium phosphate ceramics and bone autograft in a goat model. Biomaterials 2008, 29, 1177.

[304] Kruyt MC, Dhert WJ, Yuan H, Wilson CE, van Blitterwijk CA, Verbout AJ, de Bruijn JD. Bone tissue engineering in a critical size defect compared to ectopic implantations in goat J. Orthop. Res. 2004, 22, 544.

[305] Rezwan K, Chen QZ, Blaker JJ, Boccaccini AR. Biodegradable and bioactive porous polymer/inorganic composite scaffolds for bone tissue engineering. Biomaterials 2006, 27, 3413.

[306] Rodríguez-Lorenzo LM, Vallet-Regí M. Controlled crystallization of calcium phosphate apatites. Chem. Mater. 2000, 12, 2460.

[307] Elliott JC, Wilson RM, Dowker SEP. Apatite structures - JCPDS. Adv. X-ray Analysis 2002, 45, 172.

[308] Klug HP, Alexander LE. In: X-ray diffraction procedures of polycrystalline and amorphous materials ( $2^{\text {nd }}$ ed.), Wiley, New York, 1974.

[309] Mitchell BS. In: An Introduction to Materials Engineering and Science for Chemical and Materials Engineers (ed.), Wiley Interscience, Hoboken, NJ, USA, 2004, 124. 
[310] Chen CW, Oakes CS, Byrappa K, Riman RE, Brown K, ten Huisen KS, Janas VF. Synthesis, characterization and dispersion properties of hydroxyapatite prepared by mechanochemical-hydrothermal methods J. Mater. Chem. 2004, 14, 2425.

[311] Li ZY, Lam WM, Yang C, Xu B, Ni GX, Abbah SA, Cheung KMC, Luk KDK, Lu WW. Chemical composition, crystal size and lattice structural changes after incorporation of strontium into biomimetic apatite. Biomaterials 2007, 28, 1452.

[312] Rogers KD, Daniels P. An X-ray diffraction study of the effects of heat treatment on bone mineral microstructure. Biomaterials 2002, 23, 2577.

[313] Venkateswarlu K, Chandra Bose A, Rameshbabu N. X-ray peak broadening studies of nanocrystalline hydroxyapatite by Williamson-Hall analysis. Physica $B$ : Cond. Matter 2010, 405, 4256.

[314] Dorozhkin SV. Calcium orthophosphates. J. Mater. Sci. 2007, 42, 1061.

[315] Meneghin C, Dalconi MC, Nuzzo S, Mobilio S, Wenk RH. Rietveld refinement of X-ray diffraction patterns of bioapatite in human fetal bones. Biophys. J. 2003, 84, 2021.

[316] Yao F, LeGeros JP, LeGeros RZ. Simultaneous incorporation of carbonate and fluoride in synthetic apatites: effect on crystallographic and physico-chemical properties. Acta Biomater. 2009, 5, 2169.

[317] Handschin RG, Stern WB. Crystallographic lattice refinement of human bone. Calcif. Tissue Int. 1992, 51, 111.

[318] Wang XY, Zuo Y, Huang D, Hou XD, Li YB. Comparative study on inorganic composition and crystallographic properties of cortical and cancellous bone. Biomed. Env. Sci. 2010, 23, 473.

[319] Petra M, Anastassopoulou J, Theologis T, Theophanides T, Synchrotron microFT-IR spectroscopic evaluation of normal paediatric human bone. J. Mol. Struct. 2005, 733, 101.

[320] Shikinami Y, Okuno M. Bioresorbable devices made of forged composites of hydroxyapatite (HA) particles and poly-L-lactide (PLLA): part I. Basic characteristics. Biomaterials 1999, 20, 859.

[321] Barradas AMC, Fernandes HAM, Groen N, Chai YC, Schrooten J, van de Peppel J, van Leeuwen JP, van Blitterswijk CA, de Boer J. A calcium-induced signaling cascade leading to osteogenic differentiation of human bone marrowderived mesenchymal stromal cells. Biomaterials 2012, 33, 3205.

[322] Chai YC, Roberts SJ, Schrooten J, Luyten FP. Probing the osteoinductive effect of calcium phosphate by using an in vitro biomimetic model. Tissue Eng. A 2011, 17, 1083.

[323] Nakamura S, Matsumoto T, Sasaki JI, Egusa H, Lee KY, Nakano T, Sohmura T, Nakahira A. Effect of calcium ion concentrations on osteogenic differentiation and 
hematopoietic stem cell niche-related protein expression in osteoblasts. Tissue Eng. A 2010, 16, 2467.

[324] Daculsi G, LeGeros RZ, Heughebaert M, Barbieux I. Formation of carbonateapatite crystals after implantation of calcium phosphate ceramics. Calcif. Tissue Int. 1990, 46, 20.

[325] Zaffe D. Some considerations on biomaterials and bone. Micron 2005, 36, 583.

[326] Zhu XD, Fan HS, Xiao YM, Li DX, Zhang HJ, Luxbacher T, Zhang XD. Effect of surface structure on protein adsorption to biphasic calcium-phosphate ceramics in vitro and in vivo. Acta Biomater. 2009, 5, 1311.

[327] Kurashina K, Kurita H, Wu Q, Ohtsuka A, Kobayashi H. Ectopic osteogenesis with biphasic ceramics of hydroxyapatite and tricalcium phosphate in rabbits. Biomaterials 2002, 23, 407.

[328] Frosch KH, Stürmer KM. Metallic biomaterials in skeletal repair. Eur. J. Trauma 2006, 2, 149.

[329] Bozic KJ, Browne J, Dangles CJ, Manner PA, Yates AJ, Weber KL, Boyer KM, Zemaitis P, Woznica A, Turkelson CM, Wies JL. Modern metal-on-metal hip implants. J. Am. Acad. Orthop. Surg. 2012, 20, 402.

[330] Wolff JD. In: Das gesetz der transformation der knochen Hirschwald Berlin 1982 Springer (Berlin). Reprinted in English translation, 1987.

[331] Heller MO, Mehta M, Taylor WR, Kim DY, Speirs A, Duda GN, Perka C. Influence of prosthesis design and implantation technique on implant stresses after cementless revision THR. J. Orthop. Surg. Res. 2011, 13, 6.

[332] Wang T, Chow LC, Frukhtbeyn SA, Ting AH, Dong Q, Ynag M, Mitchell JW. Improve the strength of PLA/HA composite through the use of surface initiated polymerization and phosphonic acid coupling agent. J. Res. Natl. Inst. Stand. Technol. 2011, 116, 785.

[333] Wang M. Developing bioactive composite materials for tissue replacement. Biomaterials 2003, 24, 2133.

[334] van Manen HJ, Lenferink A, Otto C. Non-invasive imaging of protein metabolic labelling in single human cells using stable isotopes and Raman microscopy. Anal. Chem. 2008, 80, 9576.

[335] Stalder AF, Kulik G, Sage D, Barbieri L, Hoffmann P. A snake-based approach to accurate determination of both contact points and contact angles. Colloids Surf. A. 2006, 286, 92.

[336] Paakinaho K, Ellä V, Syrjälä S, Kellomäki M. Melt spinning of poly(L/D)lactide 96/4: effects of molecular weight and melt processing on hydrolytic degradation. Polym. Degr. Stability. 2009, 94, 438.

[337] Purac Biomaterials. Datasheet 03. Inherent viscosity and molecular weight correlations. Rev. No. 1 / September 2010. 
[338] Yamashita J, Furman BR, Rawls HR, Wang X, Agrawal CM. The use of dynamic mechanical analysis to assess the viscoelastic properties of human cortical bone. Biomed. Mater. Res. (Appl. Biomater.) 2001, 58, 47.

[339] Lakes RS, Katz JL, Sternstein SS. Viscoelastic properties of wet cortical bone Torsional and biaxial studies. J. Biomech. 1979, 12, 657.

[340] Ramaekers JGM. The dynamic shear modulus and damping of compact bovine metacarpal bone in dependence on the topography along the bone shaft. Neth. J. Zool. 1979, 29, 151.

[341] Liu F, Jin Y, Lin X, Jia D. Properties and morphology of bioceramics/poly(D,Llactide) composites modified by in situ compatibilizing extrusion. J. Appl. Polym. Sci. 2006, 102, 4085.

[342] Vaz CM, Reis RL, Cunha AM. Use of coupling agents to enhance the interfacial interactions in starch-EVOH/hydroxyapatite composites. Biomaterials 2002, 23, 629.

[343] Silva CC, Sombra ASB. Raman spectroscopy measurements of hydroxyapatite obtained by mechanical alloying. J. Phys. Chem. Solids 2004, 65, 1031.

[344] Qin D, Kean RT. Crystallinity determination of polylactide by FT-Raman spectrometry. Appl. Spec. 1998, 52, 488.

[345] Penel G, Delfosse C, Descamps M, Leroy G. Composition of bone and apatitic biomaterials as revealed by intravital Raman microspectroscopy. Bone 2005, 36, 893. [346] Yuan H, Zhou, P, Yang Z, Zhang X, de Bruijn JD, de Groot K. Bone morphogenetic protein and ceramic-induced osteogenesis. J. Mater. Sci. Mater. Med. 1998, 9, 717.

[347] Blomqvist J, Mannfors B, Pietilä LO. Amorphous cell studies of polyglycolic, poly(L-lactic), poly(L,D-lactic) and poly(glycolyc/L-lactic) acids. Polymer 2002, 43, 4571.

[348] Simitzis J, Triantou D, Soulis, S, Triantou K, Simitzis CH, Zoumpoulakis L. Correlation of hydrolytic degradation with structure for copolyesters produced from glycolic and adipic acids. J. Mater. Sci. Mater. Med. 2010, 21, 1069.

[349] von Burkersroda F, Schedl L, Göpferich A. Why degradable polymers undergo surface erosion or bulk erosion. Biomaterials 2002, 23, 4221.

[350] Hofmann D, Entrialgo-Castaño M, Kratz K, Lendlein A. Knowledge-based approach towards hydrolytic degradation of polymer-based biomaterials. Adv. Mater. 2009, 21, 3237.

[351] Rapacz-Kmita A, Paluszkiewicz C, Ślósarczyk A, Paszkiewicz Z. FTIR and XRD investigations on the thermal stability of hydroxyapatite during hot pressing and pressureless sintering processes. J. Mol. Struct. 2005, 744, 653. 
[352] Cullinane DM, Salisbury KT, Alkhiary Y, Eisenberg S, Gerstenfeld L, Einhorn TA. Effects of the local mechanical environment on vertebrate tissue differentiation during repair: does repair recapitulate development? J. Exp. Biol. 2003, 206, 2459.

[353] Hukins DWL, Mahomed A, Kukureka SN. Accelerated aging for testing polymeric biomaterials and medical devices. Med. Eng. Phys. 2008, 30, 1270.

[354] Weir NA, Buchanan FJ, Orr JF, Farrar DF, Dickinson GR. Degradation of polyL-lactide. Part 2: increased temperature accelerated degradation. Proc. IME H. J. Eng. Med. 2004, 218, 321.

[355] Agrawal CM, Huang D, Schmitz, JP, Athanasiou KA. Elevated temperature degradation of a 50:50 copolymer of PLA-PGA. Tissue Eng. 1997, 3, 345.

[356] Zhou Q, Xanthos M. Nanoclay and crystallinity effects on the hydrolytic degradation of polylactides. Polym. Degr. Stab. 2008, 93, 1450.

[357] Tsuji H, Tsuruno T. Accelerated hydrolytic degradation of poly(L-lactide)/poly(Dlactide) stereocomplex up to late stage. Polym. Degr. Stab. 2010, 95, 477.

[358] Altomare L, Gadegaard N, Visai L, Tanzi MC, Farè S. Biodegradable microgrooved polymeric surfaces obtained by photolithography for skeletal muscle cell orientation and myotube development. Acta Biomater. 2010, 6, 1948.

[359] Lamers E, van Horssen R, te Riet J, van Delft FCMJM, Luttge R, Walboomers $X F$, Jansen JA. The influence of nanoscale topographical cues on initial osteoblast morphology and migration. Eur. Cell. Mater. 2010, 20, 329.

[360] Ghibaudo M, Trichet L, Le Digabel J, Richert A, Hersen P, Ladoux B. Substrate topography induces a crossover from $2 \mathrm{D}$ to $3 \mathrm{D}$ behavior in fibroblast migration. Biophys. J. 2009, 97, 357.

[361] Tay CY, Yu H, Pal M, Leong WS, Tan NS, Ng KW, Leong DT, Tan LP. Micropatterned matrix directs differentiation of human mesenchymal stem cells towards myocardial lineage. Exp. Cell. Res. 2010, 316, 1159.

[362] Bowers KT, Keller JC, Randolph BA, Wick DG, Michaels CM. Optimization of surface micromorphology for enhanced osteoblast responses in vitro. Int. J. Oral Maxillofac. Implants 1992, 7, 302.

[363] Boyan BD, Bonewald LF, Paschalis EP, Lohmann CH, Rosser J, Cochran DL, Dean DD, Schwartz Z, Boskey AL. Osteoblast-mediated mineral deposition in culture is dependent on surface microtopography. Calcif. Tissue Int. 2002, 71, 519.

[364] Huang J, Gräter SV, Corbellini F, Rinck S, Bock E, Kemkemer R, Kessler H, Ding J, Spatz JP. Impact of order and disorder in RGD nanopatterns on cell adhesion. Nano Lett. 2009, 9, 1111.

[365] Suvorova El, Polyak LE, Komarov VF, Melikhov IV. Study of synthetic hydroxyapatite by the method of high-resolution transmission electron microscopy: morphology and growth direction. Crystall. Rep. 2000, 45, 857. 
[366] Gao J, Niklason L, Langer R. Surface hydrolysis of poly(glycolic acid) meshes increases the seeding density of vascular smooth muscle cells. J. Biomed. Mater. Res. 1998, 42, 417.

[367] Silva TSN, Machado DC, Viezzer C, Júnior ANS, de Oliveira MG. Effect of titanium surface roughness on human bone marrow cell proliferation and differentiation. An experimental study. Acta Cirurgica Br. 2009, 24, 200.

[368] Lambert BJ, Tang FW. Rationale for practical medical device accelerated aging programs in AAMI TIR 17. Rad. Phys. Chem. 2000, 57, 349.

[369] Mostafa NY. Characterization, thermal stability and sintering of hydroxyapatite powders prepared by different routes. Mater. Chem. Phys. 2005, 94, 333.

[370] Peña J, Vallet-Regí M. Hydroxyapatite, tricalcium phosphate and biphasic materials prepared by a liquid-mix technique. J. Eur. Cer. Soc. 2003, 23, 1687.

[371] Berrier AL, Yamada KM. Cell-matrix adhesion. J. Cell. Physiol. 2007, 213, 565.

[372] Larsen CC, Kligman F, Kottke-Marchant K, Marchant RE. The effect of RGD fluorosurfactant polymer modification of ePTFE on endothelial cell adhesion, growth and function. Biomaterials 2006, 27, 4846.

[373] Takagi M, Shiwaku K, Inoue T, Shirakawa Y, Sawa Y, Matsuda H, Yoshida T. Hydrodynamically stable adhesion of endothelial cells onto a polypropylene hollow fiber membrane by modification with adhesive protein. J. Artif. Organs 2003, 6, 222.

[374] Garcia JGN, Verin AD, Schaphorst K, Siddiqui R, Patterson CE, Csortos C, Natarajan V. Regulation of endothelial cell myosin light chain kinase by Rho, cortactin and p60. Am. J. Physiol. Lung Cell. Mol. Physiol. 1999, 276, 989.

[375] Wang W, Ferguson DJ, Quinn JM, Simpson AH, Athanasou NA. Biomaterial particle phagocytosis by bone-resorbing osteoclasts. J. Bone Joint Surg. Br. 1997, 79, 849 .

[376] Garnett J, Dieppe P. The effects of serum and human albumin on calcium hydroxyapatite crystal growth. Biochem. J. 1990, 266, 863.

[377] Marques PAAP, Serro AP, Saramago BJ, Fernandes AC, Magalhães MCF, Correia RN. Mineralisation of two phosphate ceramics in HBSS: role of albumin. Biomaterials 2003, 24, 451.

[378] George A, Ravindran S. Protein templates in hard tissue engineering. Nano Today 2010, 5, 254.

[379] Vogler EA. Structure and reactivity of water at biomaterial surfaces. Adv. Colloid. Interfac. 1998, 74, 69.

[380] Norde W, Giacomelli CE. BSA structural changes during homomolecular exchange between the adsorbed and the dissolved states. J. Biotechn. 2000, 79, 259. [381] Vogler EA. Protein adsorption in three-dimensions. Biomaterials 2012, 33, 1201. 
[382] Norde W, Giacomelli CE. Conformational changes in proteins at interfaces: from solution to the interface, and back. Macromol. Symp. 1999, 145, 125.

[383] Deligianni DD, Katsala N, Ladas S, Sotiropoulou D, Amedee J, Missirlis YF. Effect of surface roughness of the titanium alloy Ti-6Al-4V on human bone marrow cell response and on protein adsorption. Biomaterials 2001, 22, 1241.

[384] Woo KM, Chen VJ, Ma PX. Nnao-fibrous scaffolding architecture selectively enhances protein adsorption contributing to cell attachment. J. Biomed. Mater. Res. A $200367,531$.

[385] He G, Gajjeraman S, Schultz D, Cookson D, Qin C, Butler WT, Hao J, George A. Spatially and temporally controlled biomineralization is facilitated by interaction between self-assembled dentin matrix protein 1 and calcium phosphate nuclei in solution. Biochemistry 2005, 44, 16140.

[386] Gajjeraman S, Narayanan K, Hao J, Qin C, George A. Matrix macromolecules in hard tissues control the nucleation and hierarchical assembly of hydroxyapatite. $J$. Biol. Chem. 2007, 282, 1193.

[386] Sivasubramanyam KS. Osteoinduction by biomaterials; towards unravelling the underlying process. PhD thesis, Queen Mary University of London 2011, http://qmro.qmul.ac.uk/jspui/handle/123456789/1279.

[387] Auras R, Lim LT, Selke SEM, Tsuij H. Poly(lactic acid) - synthesis, structures, properties, processing and application. Wiley series on polymer engineering and technology. (eds. Grossman RF, Nwabunma D) 2010, John Wiley and Sons, Hoboken, New Jersey, USA.

[388] Implants for surgery - copolymers and blends based on polylactide - in vitro degradation testing. ISO 15814, 1999.

[389] Duek EAR, Zavaglia CA, Belangero WD. In vitro of poly(lactic acid) pin degradation. Polymer 1999, 40, 6456.

[390] Matsusue Y, Yamamuro T, Oka M, Shikinami Y. In vitro and in vivo studies on bioabsorbable ultra-high strength poly(L-lactide) rods. J. Biomed. Mater. Res. 1992, 26, 1553.

[391] Kellomäki M, Paasimaa S, Törmälä P. Pliable polylactide plates for guided bone regeneration: manufacturing and in vitro. Proc. Instn. Mech. Engrs. Part H: J. Engineering in Medicine, 2000, 214, 615.

[392] Bergsma JE, de Bruijn WC, Rozema FR, Bos RRM, Boering G. Late degradation tissue response to poly(L-lactide) bone plates and screws. Biomaterials, 1995, 16, 25.

[393] Chu CC. The in vitro degradation of poly(glycolic acid) sutures - effect of pH. J. Biomed. Mater. Res. 1981, 15, 795. 
[394] Deng M, Chen G, Burkley D, Zhou J, Jamiolkowski D, Xu Y, Vetrecin R. A study on in vitro degradation behavior of a poly(glycolide-co-L-lactide) monofilament. Acta Biomater. 2008, 4, 1382.

[395] Agrawal CM, Huang D, Schmitz JP, Athanasiou KA. Elevated temperature degradation of a 50:50 copolymer of PLA-PGA. Tissue Eng. 1997, 3, 345.

[396] Agrawal CM, Kennedy ME, Micallef DM. The effects of ultrasound irradiation on a biodegradable 50-50 per cent copolymer of polylactic and polyglycolic acids. J. Biomed. Mater. Res. 1994, 28, 851.

[397] Anderson JM. Perspectives on the in vivo responses of biodegradable polymers. In: Biomedical applications of synthetic biodegradable polymers (ed. Hollinger JO) CRC Press, Boca Raton, 1995, p. 223.

[398] Pitt CG, Gu ZW. Modification of the rates of chain cleavage of poly( $\varepsilon$ caprolactone) and related polyesters in the solid state. J. Control Release 1987, 4, 283.

[399] Viola J, Lal B, Grad O. The emergence of tissue engineering as a research field. 2004, retrieved on 13 August 2012 from the website http://www.nsf.gov/pubs/2004/nsf0450/start.htm.

[400] Atala A, Bauer SB, Soker S, Yoo JJ, Retik AB. Tissue engineered autologous bladders for patients needing cystoplasty. Lancet 2006, 367, 1241.

[401] Macchiarini P, Jungebluth P, Go T, Asnaghi MA, Rees LE, Cogan TA, Dodson A, Martorell J, Bellini S, Parnigotto PP, Dickinson SC, Hollander PA, Mantero S, Conconi MT, Birchall MA. Clinical transplantation of a tissue engineered airway. Lancet 2008, 372, 2023.

[402] Lysaght MJ, Jacklenec A, Deweerd E. Great expectations: private sector activity in tissue engineering, regenerative medicine and stem cell therapeutics. Tissue Eng. Part A 2008, 14, 305.

[403] Bouchie A. Tissue engineering firms go under. Nature Biotechnol. 2002, 20, 1178.

[404] website: http://www.eucia.org/

[405] Sahiner N, Jha AK, Nguyen D, Jia X. Fabrication and characterization of crosslinkable hydrogel particles based on hyaluronic acid: potential application in vocal fold regeneration. J. Biomater. Sci. Polymer E. 2008, 19, 223.

[406] Xu T, Wu M, Fneg J, Lin X, Gu Z. RhoA/Rho kinase signaling regulates transforming growth factor- $\beta 1$-induced chondrogenesis and actin organization of synovium-derived mesenchymal stem cell through interaction with the Smad pathway. Int. J. Mol. Med. 2012, 30, 1119.

[407] Li J, Wang J, Zou Y, Zhang Y, Long D, Lei L, Tan L, Ye R, Wang X, Zhao Z. The influence of delayed compressive stress on TGF-b1-induced chondrogenic 
differentiation of rat BMSCs through Smad-dependent and Smad-independent pathways. Biomaterials 2012, 33, 8395.

[408] Carragee EJ, Hurwitz EL, Weiner BK. A critical review of recombinant human bone morphogenetic protein-2 trials in spinal surgery: emerging safety concerns and lessons learned. Spine J. 2011, 11, 471.

[409] Jayabalan M, Shalumon KT, Mitha MK, Ganesan K, Epple M. Effect of hydroxyapatite on the biodegradation and biomechanical stability of polyester nanocomposites for orthopedic applications. Acta Biomater. 2010, 6, 763.

[410] Bodhak S, Bose S, Bandyopadhyay A. Role of surface charge and wettability on early stage mineralization and bone cell-materials interactions of polarized hydroxyapatite. Acta Biomater. 2009, 5, 2178.

[411] Hyon SH, Jamshidi K, Ikada Y. Effects of residual monomer on the degradation of D,L-lactide polymer. Polymer Int. 1998, 46, 196.

[412] Park A, Cima LG. In vitro cell response to differences in poly-L-lactide crystallinity. J. Biomed. Mater. Res. 1996, 31, 117.

[413] Cui H, Sinko PJ. The role of crystallinity on differential attachment/proliferation of osteoblasts and fibroblasts on poly(caprolactone-co-glycolide) polymeric surfaces. Front. Mater. Sci. 2012, 6, 47. 



\section{Acknowledgments}

These have been exciting years. Feelings were like a roller coaster: sudden changes like sharp U-bends, steep climbs to high peaks and descents to deep valleys. Every day was different, had its stories. Every day I learnt something new. From life, from people, from the lab. Each of them contributed to my growth.

Firstly, I wish to thank Dr. Yuan. 袁惠品, I will never forget the phone interview we had years ago: I simply hung it down. And I thought I just burnt the opportunity to go abroad. But then, surprisingly, you accepted me for the project. That is how our paths met. During these years you have taught me that simplicity is the key in everything. You shared your ideas and experiments with me and let me feel your trust. You kept my feet on the ground when needed, but you also let me feel good. You gave me full independence to plan and 'play' in the lab to try and learn new things. You taught me about scientifically thinking and writing interesting stories. You showed me that we could link all our experiments, which at first glance were disconnected with each other. In a nutshell, you played a key role in my working life and I believe that you gave your best to me. Also, you cooked delicious Sichuan food! 谢谢.

Prof. de Bruijn. Joost, I am really amazed to see how you could combine science with business so well. Your double-sided skills are something surprising: you run a company and are also a scientist. You are an excellent boss who created such a cheerful and harmonious atmosphere in Xpand! It is a pleasure to work there. On the other side, you are also an excellent scientist, and gave me many suggestions, ideas and help to improve myself. Together 袁惠品, you let me grow as scientist. Dank.

Xiaoman. You are a surprising guy! Every day I discover something new from you. Your meticulousness and continuous self-questioning about everything infected me. It saved me from doing rough mistakes sometimes. Thank you for all the long discussions we had on polymers and cells. Your advices and help in the lab were gold for me. Thank you for guiding me in the crowd of Chengdu. I hope we can keep good friendship in future. I wish you success with your research!

I would like to thank the 'Purac guys': Michiel van Alst, Marc-Anton Kruft and Carolien Geurts. Your contribution, both with polymer supplying and polymer science background, to this thesis has been fundamental. And thanks for inviting me at the conference in Dublin! I am grateful to the people from the BST group at the University of Twente: Prof. Grijpma, you have been a very good adviser, and your critics were really helpful and pushed me to further improve the work. Anita and Hetty, ladies, 
thank you for all the patience and the time you spent doing experiments for me! Marc, thank you for the help you gave me every time I had problems in the labs. Karin, your help has been crucial to deal with my last-minute enrollment at the University and all the bureaucracy for pursuing the PhD! I also thank the students from the TR department for their help, in particular Janneke for the Raman.

Prof. Farè. Silvia, grazie per tutto l'aiuto e la disponibilità che hai avuto in questi anni. La collaborazione che c'è stata, è stata veramente fondamentale. Spero che in futuro possiamo continuare a tenerci in contatto e a lavorare ancora insieme. Un grazie anche alle ragazze del laboratorio di Biomateriali: Serena, Lina e Monica. Siete state molto d'aiuto con vari esperimenti, e anche un'ottima compagnia quando ci siamo incontrati in Irlanda.

Now, it is time for the lab-mates: Vincent and Noel. The life in lab and office would have been very boring if you were not there! We alternated such funny talks and scientific discussions! Vincent, we practically chat on everything: from remotecontrolled cars to food, from music devices and old amplifiers to computer complaints, from drilling tools to houses, from travelling in Italy and France to simple gossip. Noel, we had so many funny discussions not only on cells, materials, protein and mice, but also about football, States, bicycles and life matters. And we had great time in Chengdu, with presentations, Hooters' table football, food on the river and pubs. Guys, thank you!

Viola, there are really no enough words to express my gratitude to you! You were always there to help me with thousands telephone calls, either private or for job, and always patience to help me dealing with any kind of problems. I also wish to thank all the other colleagues at Xpand (both current and ex-workers). It has been nice to have you around even if I seemed a bit rough. I hope we can have better time later! Remco, thank you for the help writing the Samenvatting!

Raffaele, sei stato un amico e un collega. Potevo parlare con te quando avevo qualche problema, e mi hai sempre dato ottimi consigli. Ė stato divertente quando abbiamo tirato due calci a un pallone e bevuto birra ad Utrecht. Spero che tu sia contento a Bruxelles, dove hai finalmente avuto il lavoro che desideravi. Giulia, sei stata con noi un anno, e sei stata molto d'aiuto. Spero che ti sia piaciuto star con noi e che tu abbia imparato molte cose utili per il tuo futuro. 
Other 'old' friends I met, who now are far away. April and Jeroen. Lorenzo. Gianluca. Beatrice. You have been fundamental during the first years I was in the Netherlands. I hope to see you again in future. Gli amici del campetto di Concorezzo: ho passato momenti pazzeschi con tutti voi, tra calcio, vacanze, sciate e birre. Spero di potervi rivedere ancora! Marta, dai tempi dell'università. Nonostante abbiamo passato poco tempo insieme durante le lezioni, sei sempre lì che ti ricordi di me e ti fai sentire. Questo mi rende felice. Poi, Marta, non ti ringrazierò mai abbastanza per le migliaia di pagine di appunti che mi hai passato! La cosa più impressionante di quei fogli era il fatto che fossero scritti a mano, ma che sembravano delle stampe. La scrittura era perfetta, direi una roba quasi dattilografica! Le lettere erano tutte uguali, persino la loro inclinazione era sempre la stessa!

Devo ringraziare di cuore Rossella e il Dr. Burdo. Senza il vostro aiuto nella logopedia e se non mi aveste proposto un impianto cocleare, molto probabilmente non avrei potuto fare nulla di tutto ciò. Grazie per aver aiutato e consigliato i miei genitori durante la mia crescita e quella di Stefano.

李家平, you have been the guy I could count on during these six years in the Netherlands! You welcomed me in your home in the far 2006, you gave great advices and taught me how to deal with many life matters. If I could face and win the initial feelings problems of my stay in the Netherlands, it is also because of you! And, most importantly, thank you for all your friendship with me and 潘瑧 and for being present in all the key moments of our life. Kang, Ruiqing, Haoxuan and Bo, I wish to thank all of you for the dinners and lunches we spent together. I wish the best for all you!

Silvio e Massimo, nonostante la distanza, siete gli unici che ancora sento spesso, che ancora vedo ad ogni occasione buona, che sono sempre presenti in ogni momento importante della mia vita. Ci siamo visti crescere a vicenda dai tempi della scuola materna! Mi ricordo ancora tutto come se fosse ieri. Grazie per essere i miei migliori amici. Spero che la nostra amicizia non muoia mai. Claudia, nonostante non ci conosciamo molto, sei stata vicina a me e Pan. Grazie per tutte le emails in questi anni, e per vederci ogni volta che possiamo.

Desidero ringraziare anche i miei parenti: la zia Rita e lo zio Carlo per la loro vicinanza e i momenti passati assieme. Mio cugino Giovanni, abbiamo condiviso qualche tempo assieme durante le periodiche vacanze giocando a ping-pong. Ti auguro il meglio per la tua vita futura. Manuela, ho praticamente condiviso con te i miei primi anni di vita, quasi come una sorella. Ora sono molto felice per te e Marco, e 
desidero tutto il meglio per Emma e Leonardo. Shengti and Guimin, I have spent few wonderful days in Beijing with you. I wish you all the best for your future choices and life! Hope to meet you again in future.

Stefano, caro fratello. È un peccato che ci sia una così ampia differenza d'età tra di noi. Avremmo potuto condividere più cose, crescere assieme, confidarci di più. Poi, negli ultimi sei anni ci siamo visti ancor più di rado. Avrei voluto essere lì ed essere il tuo fratellone, su cui potevi contare. Ma non è stato così. Peccato davvero. Spero che però ora possiamo cercare di essere più 'fratelli' di prima. Desidero che tu abbia un futuro radioso, che ti trovi un ottimo lavoro, che tu possa avere la sicurezza di vivere bene e dignitosamente. Te lo meriti.

Papà e mamma. Non so come iniziare. Mi ricordo tutti i momenti che abbiamo passato assieme. Le ore spese per la 'lezione', a portarmi al corso di pittura, a Varese, a giocare col pallone con me e i miei amici. Immagino anche quante volte abbiate avuto il morale a terra, siate stati tristi o preoccupati per il mio futuro e quello di Stefano. Mi fermo qui, la lista delle cose che avete fatto per noi è interminabile. Senza di voi non avrei mai potuto essere quello che sono. La cosa che più ho apprezzato da voi è stato il vostro incondizionato supporto in tutte le scelte che ho fatto, sbagliate 0 giuste che fossero. Soprattutto negli ultimi anni. Siete sempre nel mio cuore, ora e per sempre, dovunque!

潘瑧. You mean everything to me. The past four years have been wonderful. You brought light in my life, and you went into my heart making it colored. You made me smiling as I never did before. We shared happiness and sadness, smiles and tears, easy moments and difficulties, proudness and humiliation, fun and boredom. I cannot imagine how difficult it has been for you to start a life with me, tolerating all my defects and always being so patient, no matter what I did. We fought each other and became stronger together. I believe we will have a shining future! We have opposite characters, but share one thing: the love to each other. I believe we born to be a family. Honey, 我爱你. 


\section{Resume}

Davide Barbieri was born on May 25 $5^{\text {th }}$, 1981 in Vimercate, Italy. He spent his childhood in Concorezzo, with frequent periods on the Lunigiana hills, and travelling around Italy and Europe. Once graduated from the Scientific Lyceum 'Albert Einstein' (Vimercate, Italy) in 2001, he enrolled at the Polytechnic of Milano (Italy) where he obtained a Master in Biomedical Engineering

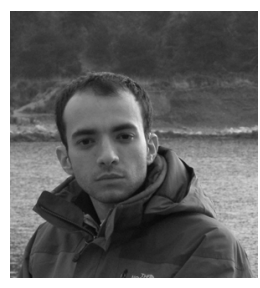
(Biomaterials) in April 2007. He spent his last nine months of studies performing an internship in Progentix BV (Bilthoven, the Netherlands) on a project that led to his final Master thesis entitled 'Nano-scaled composites of calcium phosphate apatite and polymer: preparation and characterization'. The whole project was supervised by Dr. Yuan and Prof. Farè. From April 2007 he worked for one year at Progentix BV on the development of instructive putties and injectable pastes for bone regeneration. Afterwards, in April 2008 he accepted a PhD position at Xpand Biotechnology BV (Bilthoven, the Netherlands) within Prof. de Bruijn's group and under daily supervision of Dr. Yuan. This project had as objectives to develop osteoinductive biomaterials for use in load-bearing sites and to understand the role played by the features of the biomaterials in the osteoinduction process. The PhD project has been characterized by the collaborations with Purac Biomaterials (Gorinchem, the Netherlands), the Biomaterial Science and Technology (BST) and the Tissue Regeneration (TR) departments at the University of Twente (Enschede, the Netherlands) and the Biomaterials Laboratory at the Polytechnic of Milano (Italy). The results of this research are summarized in the $\mathrm{PhD}$ thesis entitled 'Instructive composites for bone regeneration'. From December 2012, Davide will continue working at Xpand Biotechnology BV as member of the Research and Development group. 


\section{List of publications}

Main publications:

- Barbieri D, Yuan H, de Groot F, Walsh WR, de Bruijn JD (2011) Influence of polymeric gels on the bone forming ability of an osteoinductive biphasic calcium phosphate ceramic. Acta Biomaterialia 7:2007-2014.

- Barbieri D, Renard AJS, de Bruijn JD, Yuan H (2010) Heterotopic bone formation by nano-apatite containing poly(D,L-lactide) composites. Eur. Cell. Mater. 19:252261.

Patents:

- WO/2011/009635 - Injectable and moldable osteoinductive ceramic materials (Yuan H, Barbieri D, de Bruijn JD, de Groot F, Davison N)

- WO/2009/145630 - Osteoinductive nanocomposites (Barbieri D, Yuan H, de Bruijn JD)

\section{Contributions in book chapters:}

- Yuan H, Barbieri D, van Blitterswijk CA, de Bruijn JD (2011) Calcium phosphates and bone induction. In: Ducheyne P, Healy KE, Hutmacher DW, Grainger DW, Kirkpatrick CJ (eds.) Comprehensive biomaterials, vol. 5, pp. 269-280 Elsevier.

\section{Submitted papers:}

- Barbieri D, Luo X, Farè S, Grijpma DW, de Bruijn JD, Yuan H. Controlling dynamic mechanical properties and degradation of composites for bone regeneration by means of filler content.

- Barbieri D, Yuan H, Luo X, Farè S, Grijpma DW, de Bruijn JD. Implications of polymer molecular weight in instructive composites for bone tissue regeneration.

- Barbieri D, de Bruijn JD, Yuan H. Surface structure of nanocomposites and its properties.

\section{Manuscripts in preparation}

- Barbieri D, Luo X, de Bruijn JD, Yuan H. Fluid uptake as instructive factor in biomaterials for bone tissue regeneration.

- Luo X, Barbieri D, Davison N, Yan Y, de Bruijn JD, Yuan H. Making calcium phosphate ceramc osteoinductive with zinc addition.

\section{Accepted conference abstracts}

- WBC2012, Chengdu, China. 9th World Biomaterials Congress. Oral presentation 'Effect of molecular weight on bone induction by polymer/nano-apatite composites' and two poster presentations 'Effects of alkali surface treatment on apatite/polymer composites' and 'Apatite effects on viscoelasticity and degradability of polymerbased composites'.

- ESB2011, Dublin, Ireland. 24th European Conference on Biomaterials. Oral presentation 'Load-bearing composite for bone regeneration' given during the 
industrial symposium organized by Purac Biochem BV (Gorinchem, the Netherlands).

- AFPM2011, Enschede, the Netherlands. Conference on Advanced Functional Polymers for Medicine. Poster presentation 'Load-bearing composite for bone regeneration'.

- NBTE2010, Lunteren, the Netherlands. Annual Congress of the Dutch Society for Biomaterials and Tissue Engineering (NBTE). Oral presentation 'Bioactivity, in vitro degradation and dynamic mechanical properties of a composite'.

- ESB2009, Lausanne, Switzerland. 22 ${ }^{\text {nd }}$ European Conference on Biomaterials. Oral presentation 'Influence of polymeric gels on the bone forming ability of osteoinductive calcium phosphate ceramics'.

- WBC2008, Amsterdam, the Netherlands. 8th World Biomaterials Congress. Poster presentation 'Influence of nano-HA on biological properties of PLA-based composites'.

- NBTE2007, Lunteren, the Netherlands. Annual Congress of the Dutch Society for Biomaterials and Tissue Engineering (NBTE). Poster presentation 'Influence of nano-HA on biological properties of PLA-based composites'.

- Bioceramics20, Nantes, France. 20 2 th Annual International Conference on Ceramics in Medicine. Poster presentation 'Influence of nano-HA on biological properties of PLA-based composites'. 